A Study of Invigorating International Cultural Exchange After COVID-19 



\section{코로나19 이후 국제문화교류 활성화방안 연구}

A Study of Invigorating International Cultural Exchange After COVID-19

이성우·조현성·정헌주·한미애 

연구책임

이성우 문화예술정책연구실 /부연구위원

공동연구

조현성 문화연구본부/선임연구위원

외부공동연구

정헌주 연세대학교 행정학과 교수

한미애 계명대학교 국제학연구소 연구교수 

코로나19 이후 국제문화교류 활성화방안 연구

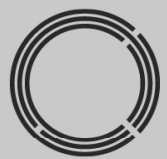

연구개요 



\section{1. 연구 목적}

- 본 연구는 코로나19 팬데믹에 따른 국제문화교류의 현황과 변화된 환경을 파악하 고, 국내 국제문화교류 현황과 인식을 파악하고, 해외 주요국가와 문화예술관련 국 제기구의 관련 정책동향을 분석하여 코로나 시대의 변화에 대응하면서 한국의 국 가이익에 부합하도록 국제문화교류의 '새로운 기준'에 맞는 국제문화교류 활성화 정책방안을 도출하는 것을 목적으로 한다.

\section{2. 코로나19 이후 국제문화교류 정책동향}

\section{가. 국제문화교류 정책 기조 변화}

- 코로나19로 인한 상황변화에 맞추어 2020년 12월 문화체육관광부는 '제1차 국제 문화교류 진흥 종합계획(2018 2022)'을 개정하였다. 개정된 국제문화교류 진흥 종합계획의 주요 개정방향으로 3 대 전략이 제시되었다. 첫째, 전략적·체계적인 국 제문화교류 기반 마련, 둘째, 국제문화교류 '새로운 기준' 선제적 대응, 셋째, 국제 문화교류의 지속가능한 생태계 구축 이다.

\section{나. 국제문화교류사업 2019년과 2020년 비교}

- 2019년과 2020년 국제문화교류 사업 건수의 증감을 살펴보았다. 유형별로 전시, 공연, 박람회 등 행사를 중심으로 이루어지는 사업 유형들의 사업 건수 감소가 눈 에 띄고, 인력관련 사업이나 교류 사업 등은 늘어난 것은 비대면 방식이나 국내 자체 사업으로 진행할 수 있는 등 사업의 대체나 다른 방식으로 사업이 가능한 사 업을 중심으로 국제문화교류 사업이 지속되었다.

- 국제문화교류사업을 코로나19 전후로 비교하여 특징과 시사점을 살펴보면 다음과 같다. 첫째, 2020년에는 기획(계획)된 사업이 취소된 사업은 많지 않다. 둘째, 대 부분의 사업이 온라인 비대면으로 전환되었다. 문화동반자 사업 같은 국제 인력교 류사업 뿐 아니라 교류행사 역시 거의 비대면으로 바꿔 진행하였다. 


\section{3. 코로나19 이후 주요국 및 국제기구 정책동향}

\section{가. 미주지역}

- 미국은 정부에서 운영하는 문화교류프로그램들을 국무뷔(United States Department of State)내 교육문화부(the Bureau of Educational and Cultural Affairs)에 서 주로 관장한다. 2020년 주요 프로그램들은 중단되기도 하였다. 하지만, 2021 년 1월 프로그램이 재개되어 진행되고 있다.

- 캐나다 예술위원회는 Arts Abroad 펀드를 운영하고 있다. 이 펀드는 캐나다 예술 가들의 국제적 활동을 지원하기 위하여 조성되었다. 코로나19로 인한 여러 여행제 한 조치와 행사 취소 등의 어려움 속에서도 캐나다 예술가들이 국제교류 활동을 지속하도록 지원하고 있다. 2019년과 2020년 기간 사이에 3천3백3십만 달러 규 모의 펀드가 집행되었다.

\section{나. 유럽지역}

- EU는 Perform Europe 프로그램 시행하고 있다. EU 지역 여러 국가출신들이 모여 공동작업을 하도록 하고 이를 온라인과 여러 지역에서 전시될 수 있도록 한 다. 크리에이티브 유럽(Creative Europe) 프로그램에 따라 혁신적이고 포괄적이 며 지속 가능한 유통 및 공연 예술 분야의 투어 모델을 지원하기 위한 새로운 도구 인 "퍼폼 유럽(Perform Europe)"이 출시되었다. 지원자들은 퍼폼 유럽 디지털 플 랫폼에 맞춘 창작 과정을 거쳐 서로 공동 작업을 하기도 한다. 서로 다른 배경의 작업자들이 함께 작업을 하여 그 작품을 전시 및 소개하게 된다

- 영국은 다양한 프로그램을 진행하고 있다. 영국관광청이 주관하는 관광교역전인 트래블 마트(Explore GB)가 온라인으로 진행되었다. 영국문화원은 코로나 19 시 대에 전 세계 사람들이 교육에 접근할 수 있고 교류가 가능하도록 단체, 기관, 자 금지원부처와 협력하여 온라인을 통해 Newton Fund 정보 및 많은 활동을 전달 하고자 노력하고 있다. 영국 문화원은 코로나 19 상황에서 문화 교류를 지속하기 위해 다양한 온라인 행사를 마련하였다. 온라인 문화 프로그램으로 대화형 웨비나 
행사인 '위기 속의 문화: 글로벌 유산 관점'을 2021년 8월 23일 개최하였다.

- 프랑스 문화원(Institut français)은 $18-25$ 세 청년층의 프랑스어 학습을 장려하기 위해 \#plusloin 이라는 디지털 캠페인을 시작하였다. 프랑스 문화원은 25년 이상 프랑스와 전 세계의 예술가 거주지를 개발하고 지원하는 프로그램을 운영해왔다. 프랑스 문화원은 코로나 상황을 극복하기 위하여 해외 각 프랑스 문화원들이 개발 한 이니셔티브들을 공유할 수 있도록 네트워크를 구성하여 운영하고 있다.

- 독일 연방 외무부 및 괴테 연구소는 문화와 교육 기관을 위한 2020 국제 구호 기 금을 운영한다. 이 기금은 파트너 국가의 기관을 지원함으로써 국제 문화 협력이 지속되도록 하기위한 것이다. 괴테-인스티튜트와 연방 외무부의 주도이지만, 구제 기금은 독일의 문화 단체와 민간 재단, 즉 독일 유네스코 위원회인 $\mathrm{DAAD}$ 의 베를 린어 귄슬러 프로그램의 지원을 받고 있다.

- 이탈리아 문화부는 이탈리아 문화에 비용을 지불하고 접근할 수 있는 온라인 플랫 폼 구축을 위하여 1000 만 유로의 예산을 배정하였다. 이 플랫폼은 일명 'Netflix of Italian culture' 로 불리며, 정식 명칭은 ITsART이다. 이 플랫폼은 유료와 무 료 콘텐츠를 모두 운영하며, 음악, 오페라, 연극, 영화, 다양한 박물관 소장품 등에 대한 접근이 해외에서도 가능하도록 하는 것이 목적이다.

\section{다. 아시아태평양지역}

- 일본국제교류기금 (Japan Foundation)은 첫 번째, JF digital collection 웹페 이지를 별도로 구성하여, 온라인 문화표현과 대화창구로 활용하고 있다. JF digital collection은 국제교류기금 일본 본부와 전세계 사무소에서 진행하는 온 라인 프로그램을 모두 보여주는 온라인 플랫폼이다. 두 번째, 일본어를 배우고자 하는 외국인을 대상으로 하는 일본어 교육프로그램에 이러닝 시스템을 적극 활용 하고 있다. 세 번째, 일본국제교류기금의 국제교류기금 아시아센터는 코로나 대응 을 위한 신규 프로그램으로 '아시아 시민교류 조성 프로그램'을 기획하였다.

- 호주에서는 현재 코로나 19로 인하여 국제문화교류 관련 프로그램인 International Arts Strategy Outcomes Fund, International Residencies Program 과 국제 
시장과 플랫폼 참여 지원(support to attend international markets and platforms)에 대한 참여가 불가능한 상황이다. 하지만, 호주는 개별 예술가들과 문화단체들이 예술 프로젝트 카테고리의 지원 사업을 통해 국제문화교류 사업을 할 수 있도록 하고 있다. 물리적 이동이 어려운 상황에서, 디지털 기술과 비대면 방식을 활용한 국제문화교류 활동을 지속하는 것을 권장하고 있다.

\section{4. 전문가 설문조사}

1) 국제문화교류 현황

(1) 한국 외교정책 수행에 있어 국제문화교류의 중요성 인식

- 한국 외교정책 수행에 있어 국제문화교류의 중요성에 대하여 물었다. 코로나 19 의 영향과 상관없이 국제문화교류의 중요성을 높게 평가하고 있는 것으로 나타났다. 다만 코로나19 팬데믹 기간 내에서는 중요하다는 응답 비중이 83.0\%로, 팬데믹 이전 97.0\%, 팬데믹 이후 98.0\%에 비해서는 낮았다.

(2) 비대면 방식의 국제문화교류 사업 수행의 효과성 인식

- 비대면 방식의 사업 수행에 대해 효과가 있다는 응답이 $43.0 \%$ 로, 효과가 없다는 응답 $27.0 \%$ 에 비해 $16.0 \%$ 더 높게 평가하고 있는 것으로 나타났다.

2) 국제문화교류 정책/사업만족도

(1) 국제문화교류 사업에 대한 정책·지원에 대한 만족도

- 국제문화교류 사업에 대한 정부의 정책과 지원에 대한 만족 정도를 묻는 설문에 코로나 19 이전에는 만족한다는 응답이 $32.0 \%$ 로 불만족한다는 응답 $7.0 \%$ 에 비해 높았던 반면, 코로나19 이후로는 불만족한다는 응답이 $30.0 \%$ 로 만족한다는 응답 $15.0 \%$ 에 비해 높았다. 
(2) 코로나19로 인한 정부의 국제문화교류사업 지원에 대한 필요성 인식

- 응답자들은 현재 시점까지 정부로부터 받은 지원들이 향후에도 더욱 필요하다고 인식하고 있다. 유연한 예산 집행 지원은 현재 정부로부터 받은 지원에 대한 필요 성 $73.0 \%$, 향후 필요성 $90.0 \%$ 로 $17.0 \%$ 더 높았다. 행정 절차의 간소화는 현재 정부로부터 받은 지원에 대한 필요성 $72.0 \%$, 향후 필요성 $86.0 \%$ 로 더 높았다.

(3) 위기/재난상황 시 국제문화교류사업 추진을 위한 정책의 필요성

- 향후 코로나 19 와 같은 위기/재난상황이 발생했을 때 국제문화교류 사업 추진을 위해 필요한 정책에 대해 설문한 결과, 필요하다는 응답 비중을 기준으로, '국제문 화교류 사업 기관 네트워킹 및 협업 강화' $91.0 \%$, '기관별 네트워크 구축 및 연계 사업 개발' $88.0 \%$, '사업계획 플랜B 설계 지원' $88.0 \%$ 등의 순으로 나타났다.

3) 코로나 이후 국제문화교류 발전방향

(1) 코로나19 이후 국제문화교류 활성화를 위한 정책의 필요성

- 코로나19 팬데믹에서 벗어난 이후, 국제문화교류 활성화를 위해 필요한 정책에 대 해 설문하였다. 그 결과, 가장 높은 응답이 나온 항목은 '국제문화교류 국내체계 정비 93.0\%, '온라인/비대면 콘텐츠 제작·유통 활성화 지원' $92.0 \%$, '국제문화교 류 정책의 구체화, 체계화 $91.0 \%$ 등의 순으로 나타났다.

(2) 코로나19 이후 민간분야 국제문화교류 활동 활성화를 위해 필요한 지원

- 코로나19 팬데믹 이후, 민간분야의 국제문화교류 활동 활성화를 위해 필요한 정부 의 지원 형태에 대해 설문한 결과, '온라인 디지털 국제문화교류 플랫폼을 통한 활동 지원’ $88.0 \%$, '국제문화교류 정보공유 및 활용 지원(네트워크 구축)' $88.0 \%$, 콘텐츠 디지털전환 등 인력 교육 및 장비사용 지원 $86 \%$, 사업비용 지원 $82 \%$, 한 국 국제문화교류 온라인 플랫폼 구축 및 활성화 지원 $80 \%$ 등으로 나타났다. 
(3) 온라인/비대면 콘텐츠 활성화를 위해 필요한 정책적 지원

- 응답자의 $70.0 \%$ 가 온라인/비대면 플랫폼을 구축하고 이를 활성화하는 데에 정책 적으로 지원이 필요하다고 보았으며, 이어서 온라인/비대면 콘텐츠 제작에 필요한 비용 지원이 필요하다는 응답이 $67.0 \%$, 콘텐츠를 제작할 수 있는 공간 및 시설, 장비에 대한 지원이 필요하다는 응답이 $60.0 \%$ 등의 순으로 나타났다.

\section{5. 국제문화교류 활성화위한 정책과제}

\section{가. 대전환기 가치기반 국제문화교류}

\section{1) 국제문화교류를 통한 공유가치의 창출}

- 대전환기 국제문화교류는 가치기반(value-based) 국제문화교류가 되어야 하며, 앞으로 국제문화교류는 한국의 문화적 가치와 보편적인 가치(universal values)가 융합된 가치에 기반을 둘 필요가 있다. 즉, 우리나라의 문화적, 역사적 가치와 더불 어 문화교류의 대상과 상호 공유할 수 있는 보편적 가치는 무엇인가에 대한 논의와 문화적 실천이 중요하다.

- 국제문화교류의 기반이 될 수 있는 보편적 가치로 지구적 차원에서 형성된 국제규 범(global norm)을 준용하는 것이다. 오늘날 가장 중요한 국제규범 중 하나는 유 엔 주도로 설정된 지속가능발전목표(Sustainable Development Goals, SDGs) 의 토대를 제공하는 기본 가치인 5Ps, 즉, 인간(people), 지구·환경(planet), 번영 (prosperity), 평화(peace), 파트너십(partnership)이다.

\section{2) 보편적 가치 추구를 위한 국내 기반 조성}

- 가치기반 국제문화교류를 위해서는 이를 위한 국내 기반 조성이 필요하다. 보편적 가치를 내재화하지 않은 국내의 문화적 현실은 국제문화교류의 효과를 저해할 수 있다는 우려와 연계되어 있다. 한류 현상이 지속되면서, '반한' 감정이나 반 한류 정서 역시 지속되고, (포스트-)코로나19 상황에서 이러한 경향이 강화될 가능성을 
배제할 수 없다.

- 코로나19 시대와 그 이후를 바라보면서, 국제문화교류의 근간이라고 할 수 있는 국내의 문화 관련 제도, 관행에 대한 정비가 필요하다. 문화예술분야 종사자의 삶 의 질을 제고하고, 다양한 권리를 보장하며, 불평등하고 불공정한 관행을 철폐하 고, 창의적이고 혁신적인 아이디어 창출을 권장하고 보장하며, 환경 친화적인 규 범, 준칙, 관행, 행위 등이 제도화될 수 있도록 노력해야 한다.

3) 문화와 ODA의 연계 강화: 문화 ODA 확대와 문화 주류화

- 국제문화교류에서 $\mathrm{ODA}$ 는 매우 중요한 구성요소이다. 하지만, 한국의 국제문화교 류 사업에서 ODA 사업 특히 문화ODA 사업은 중요하게 다루어지지 않고 있다. 개발도상국과의 국제문화교류를 위해서는 문화 부문 공적개발원조(ODA)의 양적, 질적 제고가 필요하다. 먼저, 문화 $\mathrm{ODA}$ 의 양적 확대가 필요하다.

- 국제문화교류 전략과 문화 $\mathrm{ODA}$ 의 비전, 추진전략, 목표를 일치시키는 정책일관성 (policy coherence) 제고 노력이 필요하다. 즉, 「문화 ODA 기본계획」을 수립하 여, 전략적·체계적 문화ODA 수행을 준비해야 한다.

- 문화를 주류화(culture mainstreaming)하려는 노력이 필요하다. 즉, 우리나라 $\mathrm{ODA}$ 정책 및 수행의 모든 부분에 있어서 문화의 관점에서 바라보고, 이에 미치는 영향을 고려하는 것이다. 문화는 SDGs 달성에 매우 중요한 역할을 한다.

\section{나. 회복탄력성 제고를 위한 거버넌스 구축}

1) 에자일 거버넌스(agile governance)를 통한 회복탄력성 제고

- 문화예술분야에 적합한 회복탄력성 개념은 미래 예측에 기반을 둔 능동적 적응능 력으로서 “새로운 상태로 나아가는(bouncing forward) 회복탄력성” 개념이다.

- 코로나19 팬데믹과 같이 언제든지 닥쳐올 수 있는 충격, 위기 상황에서 능동적으 로 대응하고 새로운 모습으로 국제문화교류를 (재)구성하고 더 큰 가치를 창출하기 위해서는 에자일 거버넌스 구축이 필요하다. 회복탄력성 제고를 위한 에자일 거버 
넌스는 변동성이 큰 상황에서 충격이나 위기가 발생할 가능성이 있거나 실제로 발 생하였을 때, 무대응(non-response)이나 때늦은 대응의 비용이 잘 준비되지 못하 지만 신속하게 대응하는 비용보다 훨씬 크다는 점에서 그 필요성이 높다.

\section{2) 공공-민간부문과의 파트너십 강화}

- 국제문화교류의 회복탄력성을 위해서는 다양한 문화적 이해당사자들(cultural stakeholders) 사이의 파트너십, 협업이 중요하다. 파트너십을 통해서 정부와 공 공부문은 국제문화교류의 세계적 현황과 관련 민간부문의 현실과 요구를 제대로 파악할 수 있으며, 민간부문 역시 정부와 공공부문을 통해서 다양한 정보와 정책방 향 등을 확인하고 리스크를 회피하기 보다는 감수할(risk-taking) 수 있다.

- 미래의 파트너십은 지방자치단체, 개인 창작자, 일반 시민(이주민 포함), 대상국의 중앙-지방정부, 문화예술 관계자, 일반 시민 등 모든 이해관계자를 포함한다.

3) 한국국제문화교류 플랫폼 구축: K-Culture Portal

- 현재 한국의 문화와 관련된 다양한 정보와 웹사이트가 존재한다. 하지만, 국제문화 교류의 서비스 공급자와 소비자를 연결해주고 관련된 정보를 한 곳에서 확인할 수 있는 통합적 플랫폼을 찾기는 어렵다. 다양한 이해당사자의 필요와 관심이 반영된 새로운 한국문화 포털, 플랫폼이 필요하다.

\section{다. 국제문화교류 관리체계 기반 구축}

1) 국제문화교류 성과관리체계 구축

- 국제문화교류의 중장기적 발전과 성장을 위해서는 이에 대한 성과관리가 필요하 다. 국제문화교류 역시 국민의 세금이 주요한 재원이며, 결국 납세자인 국민의 관 점에서 유의미한 결과를 창출하였는가가 중요한 요소로 간주될 필요가 있다.

- 유사한 사례·연구를 기반으로 국제문화교류 성과를 측정하기 위한 지표를 개발하 고, 성과를 측정하며 정책 환류 노력을 전개해야 한다. 우리나라 재정성과관리제도 
내 "재정사업 자율평가제도," "국제개발협력 사업시행기관 자체평가" 등을 고려한 다면, 국제문화교류 사업의 평가기준으로 적절성(relevance), 효율성(efficiency), 효과성(effectiveness), 영향력(impact), 지속가능성(sustainability), 일관성 (coherence) 등을 제시하고, 이를 국제문화교류(사업)의 시간적 순서에 따라 "계 획(plan) $\rightarrow$ 투입(input) $\rightarrow$ 활동(activity)·과정(process) $\rightarrow$ 산출(output) $\rightarrow$ 결 과(outcome) 영향(impact)" 등 각각의 단계별 성과지표를 개발할 필요가 있다.

\section{2) 위험관리(risk management)}

- 코로나19, 포스트-코로나19 시대 국제문화교류와 관련된 다양한 리스크를 식별하 고, 이에 대한 대응, 관리체계를 고려할 필요가 있다. 많은 국제문화교류 사업이 온라인으로 진행되거나, 온-오프라인 혼합으로 진행될 가능성이 있다. 다양한 정 보, 때로는 민감한 정보(개인정보 등) 누출 등 사이버안보 측면에서 리스크 관리가 필요하다. 또한, 국가 간 경쟁과 갈등이 커지는 상황에서 국제문화교류 과정에서 발생할 수 있는 우리나라 문화에 대한 오해, 잘못된 해석, 악의적인 비난과 이의 지속적인 재생산 등에 대하여 즉각적으로 대응하고, 부정적 영향력을 상쇄할 수 있는 방안이 선제적으로 고려될 필요가 있다.

- 또한, 국제문화교류 시행 인력과 관련된 리스크 역시 관리될 필요가 있다. 국제문 화교류를 실행하는 인력에 대한 인권 교육, 성인지 교육, (성)폭력 예방 교육, 문화 적 다양성에 대한 교육 등이 수행되고 체계적으로 관리될 필요가 있다.

\section{3) 국제문화교류와 연관된 다양한 민관프로그램의 통합적 관리}

- (포스트)코로나19 시기를 바라보면서 국제문화교류와 관련된 다양한 사업, 프로그 램에 대한 통합적 관리의 기반을 구축할 필요가 있다. 외교부(한국국제교류재단 포 함)는 전체 중앙행정기관 중 가장 많은 규모이다. 문화체육관광부는 공공외교 활동 추진과 국제문화교류를 연계하여 정책을 수립, 집행하고 있다. 문화체육관광부-외 교부 간 국장급 회의의 정례적 개최를 진행하는 등 국제문화교류와 (문화)공공외교 간 시너지를 창출하기 위한 노력이 필요하다. 
- 우리나라 기업, 특히 문화 관련 기업들의 국제문화교류 사업 수행에도 영향을 미칠 것이다. 민간부문에서의 다양한 국제문화교류 사업에 대한 파악과 협업이 필요하 다. 국제문화교류와 연관된 다양한 정책, 사업, 프로그램을 통합적으로 관리하기 위한 노력이 필요하다.

\section{라. 온라인 오프라인 융합 프로그램}

1) 온라인 국제문화교류 인프라 지원

- 국제문화교류의 디지털 전환을 위한 인프라 구축과 역량 강화 등 전략적 지원을 추진할 필요가 있다. 국제문화교류와 관련된 콘텐츠 제작을 위한 비용, 시설, 공간, 장비 지원뿐만 아니라 인력 지원, 역량 강화(교육, 홍보, 유통 등) 등 세부 분야별 맞춤형 지원이 필요하다.

- 제작 관련 지원뿐만 아니라 교류대상국의 온라인 국제문화교류와 관련된 준비도, 수용성에 대한 조사도 필요하다. 즉, 지역별, 국가별, 세대별로 서로 상이한 온라인 플랫폼을 활용할 가능성이 높다는 점에서 현지 맞춤형 콘텐츠 제작 지원이 필요하 다. 현지에서 온라인 국제문화교류가 잘 수행되기 위해서 인프라 구조가 필요하다 면, (문화)ODA 및 기업의 CSR/ESG 활동과 연계한 사업을 추진할 필요가 있다.

2) 한국문화체험 Kit: 내국인-국내 거주 외국인-해외 현지인 연계 체험

- 우리나라의 다양한 문화를 체험할 수 있는 kit을 제작하여, 우리나라 시민, 국내 거주 외국인, 해외 교민, 해외 현지 주민 등 관심이 있는 다양한 개인들이 온라인 으로 참여하는 방식이다. 문화체험 kit는 공예, 서예, 도자기, 한국화 등 전통문화 를 체험할 수 있는 도구뿐만 아니라 박물관, 미술관 큐레이터와 함께하는 체험(3D 종이모형 등), k-pop 댄스, $\mathrm{k}$-drama 주인공 체험, 한국 전통음식 만들기(1인용 김장김치 키트) 등 다양한 kit가 포함된다. 
3) 메타버스 구축을 통한 국제문화교류의 디지털 가상화, 일상화

- 국제문화교류 역시 메타버스를 활용하여 포스트-코로나19 시대를 준비할 필요가 있다. 특히, 국제문화교류의 중요한 축을 차지하는 공연·전시 활동과 메타버스를 연계할 수 있다. 가상현실, 증강현실, 확장현실 등 실감기술을 활용한 가상 박물관, 미술관 등은 이용자에게 실제와 비슷한 경험을 선사하고, 이용자들끼리의 상호작 용을 가능하게 한다는 점에서 국제문화교류의 목적에 부합하는 활동이 가능하다.

- 메타버스 기술을 활용하여 온라인 학습 시스템을 보완하여 사용자들의 관심을 더 잘 유도하고 학습의욕을 고취할 수 있다. 온라인 수업이 잘 진행되려면, 강사들이 학생들의 얼굴을 보면서 실시간으로 강의할 수 있어야 하고, 수업시간에 학생들의 소그룹 활동이 가능해야하며, 학습 내용을 확인하기 위한 퀴즈도 동시에 자유롭게 시행될 수 있어야 한다. 강사가 일방적으로 혼자 설명하지 않고, 학생들의 의견도 자유롭게 들을 수 있고, 학생 상호간의 소통도 잘 이루어질 수 있도록 해야한다. 



\section{목차}

제1장 서론

제1절 연구배경 및 목적 3

1. 연구배경 3

2. 연구목적 5

제2절 연구범위 및 방법 6

1. 연구범위 6

2. 연구방법 8

3. 연구수행체계 9

제2장 국제문화교류 외부 환경 변화 ……....................................................... 11

제1절 국제정치 환경 13

제2절 경제 환경 19

제3절 사회문화적 환경 26

제4절 기술 환경 30

제5절 코로나19로 인한 변화 34

제3장 국내외 국제문화교류 정책동향 …………………………………………......4 49

제1절 코로나19 이후 국제문화교류 정책동향 51

1. 문화체육관광부 주요 계획 및 예산 51

2. 시기별 사업현황 58

3. 주요기관별 사업현황과 계획 79

제2절 코로나19 이후 주요국 및 국제기구의 정책동향 95

1. 미주지역 96

2. 유럽지역 98

3. 아시아태평양 지역 107 
4. 국제기구 115

$\begin{array}{ll}\text { 제3절 소 결 } & 124\end{array}$

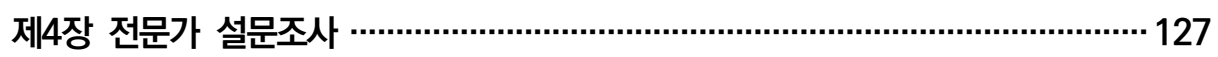

제1절 설문조사 개요 129

1. 조사목적 129

2. 조사방법 130

제2절 설문조사 결과 분석 133

1. 국제문화교류 현황 133

2. 국제문화교류 정책/사업만족도 $\quad 140$

3. 코로나 이후 국제문화교류 발전 방향 145

제3절 소 결 150

제5장 국제문화교류 활성화위한 정책과제 ……............................................. 153

제1절 정책추진 환경 155

1. 국제문화교류 추진 환경 155

2. 정책추진 필요성 157

제2절 정책과제 제안 160

1. 대전환기 가치기반 국제문화교류 160

2. 회복탄력성 제고를 위한 거버넌스 구축 170

3. 국제문화교류 관리체계 기반 구축 175

4. 온라인 오프라인 융합 프로그램 181

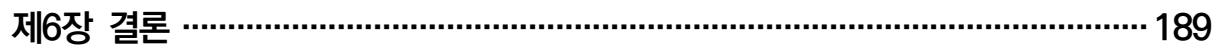

제1절 요약 191

제2절 정책함의 196

\section{참고문헌 / 199}

ABSTRACT / 205

부록 - 전문가 의견조사지 양식 / 207 


\section{표 목차}

〈표 2-1〉역내 주요 수출국 성장률 추이

〈표 2-2〉 소득 5분위별 가구소득 평균 및 점유율 20

〈표 2-3〉가구의 경제상황 22

〈표 2-4〉 소득 5분위별 가구소득 평균 및 점유율 22

〈표 2-5〉4차 산업혁명의 핵심적 와해성 기술들 31

〈표 2-6〉2018 디지털 기술 10대 이슈 32

〈표 2-7〉 에어비앤비 온라인체험코스 43

〈표 3-1〉 '제1차 국제문화교류 진흥 종합계획' 성과 53

〈표 3-2〉 문화체육관광부 20년, 21년 국제문화교류 업무계획 발췌 54

〈표 3-3〉 문화예술 해외교류 관련 사업 결산내역 55

〈표 3-4〉 문화예술 해외교류사업 예산 55

〈표 3-5〉2019년과 2020년 국제문화교류 사업 유형별 분류 59

〈표 3-6〉2019년과 2020년 기관별 사업건수 비교 59

〈표 3-7〉 2019년과 2020년 주요 국제문화교류사업 비교 61

〈표 3-8〉2019년 국제문화교류사업 분류 63

〈표 3-9〉 수교계기 문화행사 주요 추진실적 총괄 표(2019) 64

〈표 3-10〉 문화동반자 직접사업 내역(2019) 68

〈표 3-11〉 문화동반자 소속기관사업 내역(2019) 69

〈표 3-12〉 2020년 국제문화교류사업 분류 71

〈표 3-13〉 비대면 한국-러시아 문화의 달 사업 총괄표(2020) 73

〈표 3-14〉2021년 국제문화교류사업 분류 78

〈표 3-15〉2021년 문화체육관광부 부서별 국제교류사업 계획 79

〈표 3-16〉기관별 국제문화교류사업 79

〈표 3-17〉 프랑스 문화원 네트워크 코로나 대응 이니셔티브 103

〈표 3-18〉 상하이시 온라인 신경제 발전촉진의 행동방안 12개 중점발전분야 110

〈표 4-1〉 전문가 설문조사 항목 구성 131

〈표 4-2〉 응답자 특성 132 
〈표 5-1〉국제문화교류 정책과제 159

〈표 5-2〉5Ps와 SDGs 161

〈표 5-3〉 문화와 관련된 SDGs 세부목표 162

〈표 5-4〉 한국의 문화 ODA 규모(2006 2019) 165

〈표 5-5〉 문화와 관련된 SDGs 세부목표 168

〈표 5-6〉 문화공공외교의 추진전략 179

〈표 5-7〉 기관별 공공외교 사업규모 및 예산 180

〈표 5-8〉2020년 한국 공연 스트리밍 현황 182

〈표 5-9〉미 아트펀드 서베이 결과 184 


\section{그림 목차}

[그림 2-1] 유럽 망명신청 추이 17

[그림 2-2] 실질 국내총생산과 실질 국민총소득 증가율 추이 21

[그림 2-3] 디지털 경제 개념의 수직적 분류 24

[그림 2-4] 19세 이상 국민의 계층이동 가능성에 대한 인식 26

[그림 2-5] 1인 가구 비중 28

[그림 2-6] 여가활용 및 하루평균 여가시간 비교 29

[그림 2-7] 코로나19 이후 EU에 대한 인식변화 36

[그림 2-8] 코로나19 전후 환경변화와 국제문화교류 변화요인 47

[그림 3-1] '제1차 국제문화교류 진흥 종합계획' 정책목표 및 추진전략 52

[그림 3-2] 개정 ‘제1차 국제문화교류 진흥계획' 정책 목표 및 추진전략 57

[그림 3-3] 위기 속의 문화 웨비나 영상 100

[그림 3-4] 독일 관광공사 'Discover Germany From Home' 페이지 105

[그림 3-5] JF digital collection 웹페이지 107

[그림 3-6] 유네스코 문화 간 대화 소개 페이지 118

[그림 4-1] 코로나19 이후 국제문화교류 회복에 대한 기대 정도 133

[그림 4-2] 한국 외교정책 수행에 있어 국제문화교류의 중요성 134

[그림 4-3] 비대면 방식의 국제문화교류 사업 수행의 효과성 정도 135

[그림 4-4] 코로나19로 인한 국제문화교류 사업의 변동이 큰 국가 137

[그림 4-5] 코로나19 기간 내 온라인 교류사업 참여 여부 138

[그림 4-6] 교류사업 참여시 온라인/비대면 콘텐츠 활용방식 138

[그림 4-7] 교류사업 참여시 온라인/비대면 프로그램이 유통·송출된 플랫폼 139

[그림 4-8] 온라인/비대면 프로그램에 참여하지 않은 이유 140

[그림 4-9] 국제문화교류 사업에 대한 정책-지원에 대한 만족도 142

[그림 4-10] 정부로부터 받은 지원 및 향후 필요한 지원에 대한 필요성 인식 143

[그림 4-11] 위기/재난상황시 국제문화교류사업 추진을 위한 정책의 필요성 144

[그림 4-12] 코로나19 이후 국제문화교류 활성화를 위한 정책의 필요성 145

[그림 4-13] 코로나19 이후 민간분야 국제문화교류 활동 활성화를 위해 필요한 지원 146 
[그림 4-14] 코로나19 이후 온라인/비대면 콘텐츠 부상에 대한 전망 및 평가 147

[그림 4-15] 온라인/비대면 콘텐츠 활성화를 위해 필요한 정책적 지원 148

[그림 4-16] 코로나19 이후 ‘문화로’ 개선 방향 149

[그림 5-1] 한국의 문화 ODA 규모(2006 2019) 166

[그림 5-2] 국제문화교류 및 이와 관련된 정부·민간 프로그램의 연계성 178 
코로나19 이후 국제문화교류 활성화방안 연구

제1장

서론 



\section{제1절 연구배경 및 목적}

\section{1. 연구배경}

\section{가. 코로나로 인한 문화예술활동 전반의 위축}

전 세계적으로 거의 모든 국가들은 코로나 19(COVID-19)의 세계적 대유행(Pandemic) 으로 인하여 개별 국가별 방역 대책으로 인하여 국내 사화경제문화 전반에 큰 충격을 받았다. 방역을 위한 봉쇄조치, 사회적 거리두기, 격리 등으로 인하여 문화시설의 휴관 이 장기화되고, 공연 및 전시 등은 무기한 연기되거나 취소되어 문화예술 활동 전반이 위축되었다. 한국의 경우도 2020년 계획되었던, 문화예술 행사들은 취소, 연기 또는 소 규모 행사로 전환되어 진행되거나, 비대면 온라인 행사 대체되었다. 박물관 및 미술관 관람수입 감소 등의 피해액은 $\boldsymbol{\Delta}$ 관람료(696억 3200만 원) $\boldsymbol{\Delta}$ 교육·체험프로그램(187억 3000 만 원) 편의시설 운영(220억 원)에 달하는 것으로 나타났다. 또한 공연 및 미술시 장의 피해금액은 4492억 원, 프리랜서 예술인 고용피해 2918억 원으로 추정되었다.1) 이러한 취소, 연기 및 행사방식 전환은 국제문화교류 행사에서도 동일하게 진행되었다. 문화체육관광부와 한국국제문화교류진흥원이 2021년 1월 28일 함께 발표한 2021년 해외 한류 실태조사(2020년 기준)' 결과에 따르면, 코로나 19 로 인해 해외 공연과 팬 미 팅 등 한류 스타들의 팬들과의 직접적인 소통이 줄어들어든 결과, 한국 문화콘텐츠에 대한 관심도가 코로나19이전보다 하락한 것으로 조사되었다. 국제문화교류의 감소가 한 류로 대변되는 한국 문화에 대한 관심의 축소로 이어지고 있음을 보여준다. 외교부 산하 국제교류 업무를 담당하는 기관인 한국국제교류재단은 2020년 예산 중 80억 원을 국고 에 반납하였다. 구체적으로 $\mathbf{\Delta}$ 해외대학 기금교수직 설치를 위한 교수직 설치사업 예산 15억원, $\boldsymbol{\Delta}$ 객원교수파견 5억원, $\boldsymbol{\Delta}$ 해외유력인사초청 5억9000만원, $\boldsymbol{\Delta}$ 차세대 지도자방

1) 머니파워. 21.02.07. "코로나로 관광·문화예술·콘텐츠·체육 분야 피해규모 108조7800억원" 
한 초청 6억9500만원이 감소하였음. 그리고 $\mathbf{\Delta}$ 한국문화예술교류확대 예산도 오프라인 행사를 취소하고, 온라인 행사로 변경하면서 12억6800만원이 줄었다.2)

\section{나. 코로나19 이후 문화영역 보호에 대한 국제사회의 움직임}

코로나 19 로 인하여 봉쇄조치가 취해지고 사람들이 모이지 못하는 상황이 발생하면 서, 문화예술 영역의 활동을 정상적으로 진행하기 힘든 상황이 되었다. 이에 코로나 상 황을 고려한 문화예술 영역에 대한 보호 필요성을 제기하는 목소리들이 국제사회에서 나오고 있다. 2021년 2월 1일부터 5일까지 제14차 문화다양성협약 정부간위원회가 온 라인으로 개최되었다. 이번 회의에서 코로나 19 로 인해 어려움에 처한 전 세계 문화예술 계의 회복을 위한 다양한 논의가 진행되었다.3) 회원국들은 또한 국제문화다양성기금 운영, 문화분야 종사자들의 코로나19 대응을 위해 진행한 레질리아트(ResiliArt) 토론 회, 문화다양성 제고 정책 자료 수집 및 공유 등을 주도해 온 유네스코 사무국의 활동에 감사의 뜻을 표하고, 어려움에 처해 있는 전 세계 문화예술계의 회복력을 강화하기 위한 다양한 소통과 국제적 연대 및 협력에 노력을 기울여 줄 것을 요청했다. 세계은행의 도 시, 재난 위기관리 관련 부서 글로벌 디렉터, 도시정책전문가, 유네스코 문화부 부총장 인 세명의 저자들(Sameh Wahba, Ernesto Ottone R., Rana Amirtahmasevi)이 공 동작성한 “코로나 19 회복에서의 문화(Culture in the COVID-19 recovery: Good for your wallet, good for resilience, and good for you)"에서 문화 분야가 국가경 제에 기여한 바를 간과하지 말고 코로나19 회복과정에서 문화창의분야 산업(Cultural and creative industries)에도 지원할 것을 촉구하였다.4) 이 밖에도 다양한 문화 분야 보호를 위한 시도들이 지속되고 있다. 코로나 상황이 장기적으로 진행될 것으로 고려한 바탕 위에 문화영역 보호에 대한 움직임에 기반하여, 국제문화교류는 그 계획을 일정하 게 수정하고, 새롭게 정책을 추진할 필요가 있다.

2) 뉴스원. 2020.10.19. "올해 국제교류 지원에산, 코로나19여파에 80억 국고 반납"

3) 출처: 유네스코홈페이지(https://www.unesco.or.kr/data/unesco_news/view/777/1239/page/0?) 검색일 - 2021년 3월 2일

4) 출처: 세계은행 블로그

(https://blogs.worldbank.org/sustainablecities/culture-covid-19-recovery-good-your-walletgood-resilience-and-good-you) 검색일 - 2021년 3월 2일 


\section{다. 코로나19로 인한 국제문화교류의 새로운 정책적 지원필요}

코로나19로 인한 사회적 상실감과 심리적경제적 불안과 어려움에 처한 시민들에게 여러 문화예술활동을 장려하고, 문화교류를 진행할 수 있도록 정책적 지원을 할 필요성 은 더욱 증가되었다. 코로나19로 인하여 국제문화교류 중단이 장기 지속된다면, 한국의 문화상품 수출이나 한류의 확산 등에 장기적으로 피해가 발생하게 되면, 한국의 문화외 교 증진이라는 정책방향에도 적지 않은 피해가 발생할 것으로 생각된다.

코로나 상황 하에서도 한국은 문화 선진국으로서 문화 외교적 역할 증대가 필요하며, 신기술을 접목한 새로운 방식의 교류 방안을 고려한 국가 간 국제문화교류의 지속적인 확대 방안을 모색할 필요가 있다. 코로나로 인한 예외적 상황이 지속되고, 교류 상대국 의 상황이 개선되지 않는 속에서 한국의 문화교류정책을 어떻게 진행해야할 지에 대한 전반적인 검토가 필요하다. 전체적인 국제문화교류 정책의 원칙과 방향을 고민하고, 현 재 교류현황을 점검하면서, 해외의 참고시례 등을 참조하여 전반적인 방향성을 검토할 필요가 있다. 신규 사업 측면에서는 코로나 19 상황에서 비대면 문화교류 진행을 위한 예산 지원 및 문화콘텐츠 디지털화 등이 필요한 상황이다. 또한, 코로나 19 상황 하에서 기존의 국제문화교류 계획을 그대로 진행할 수 있을지, 전체적으로 국제문화교류정책의 새로운 변화를 추구할 필요가 있는지에 대한 검토가 필요하다. 코로나 19 시대의 변화를 고려한 국제문화교류 방안 검토와 새로운 방식의 교류방안의 필요성이 커지고 있다.

\section{2. 연구목적}

본 연구는 코로나19 팬데믹에 따른 국제문화교류의 현황과 변화된 환경을 파악하고, 국내 국제문화교류 현황과 인식을 파악하고, 해외 주요국가와 문화예술관련 국제기구의 관련 정책동향을 분석하여 코로나 시대의 변화에 대응하면서 한국의 국가이익에 부합하 도록 국제문화교류 활성화 정책방안을 도출하는 것을 목적으로 한다. 


\section{제2절 연구범위 및 방법}

\section{1. 연구범위}

\section{가. 공간적 범위}

- 문화체육관광부를 중심으로 대한민국 중앙정부의 정책 현황을 파악한다.

- 국제문화교류 관련하여 문화관련 국제기구(UNESCO, IFACCA, ICO, ENCATC 등) 및 미주권, 유럽권, 아시아태평양권 등 권역별 주요국의 정책대응 사례를 분석한다.

\section{나. 시간적 범위}

- 코로나사태가 발생한 2020년 1월 이후부터 2021년 6월 현재까지 상황 분석을 주 분석 범위로 하고, 코로나사태 발생 이전의 국제문화교류 주요 계획 및 사업 등을 참조한다.

- 코로나가 안정이 되더라도 전염병의 전파를 고려한 정책방안 도출이 필요할 것 이다. 이에 향후 2 3년 내에 직접적인 대응을 위한 정책방안에 기여를 목적으 로 한다.

\section{다. 내용적 범위}

- 국제문화교류 정의 : 현재「국제문화교류진흥법」에서는 국제문화교류를 "문 화, 예술, 관광, 체육 등의 관련 분야에서 국가 간 상호 문화에 대한 이해를 증진하기 위하여 수행하는 국제적 협력 및 활동(제2조)"로 정의하여 관광과 체 육 분야도 포괄하고 있다. 여기에서 문화란 관광, 체육 분야까지 포괄하는 넓 은 의미에서의 문화로 정의하고 있다. 
- 본 연구에서는 과제 시행 계기, 과제 연구기간 등을 고려하여 국제문화교류를 "문화, 예술 등의 관련 분야에서 국가 간 상호 문화에 대한 이해를 증진하기 위하여 수행하는 국제적 협력 및 활동”으로 보고, 문화와 예술분야에 한정하여 국제문화교류관련 연구를 진행하고자 한다.

- 국제문화교류 환경, 국제문화교류 필요성 논리 변화, 권역별 주요국가들의 국 제문화교류를 위한 정책 변화를 분석하고 이를 기반으로 한국의 국제문화교류 활성화를 위한 정책과제를 도출하고자 한다.

- 첫째, 코로나 19 확산, 디지털 기술의 발전, 국제정세 변화 등을 중심으로 최근 의 국제문화교류 환경변화를 검토한다.

- 둘째, 한국의 국제문화교류 사업 현황은 문화체육관광부 및 산하기관을 중심으 로 진행하고, 필요시 기타 국제교류재단 등의 기관을 대상기관에 추가하여 최 근 3년간의 사업 변화 양상을 분석한다.

- 셋째, 코로나 19 이후 국제문화교류 필요성 논리를 검토한다. 국제적 갈등이 심화되는 상황에서 중견국으로서 국제문화교류 확대, 코로나 19 이후 한국의 문화적 영향력 확대를 위한 상호 교류·협력 확대 필요성 등을 검토한다.

- 넷째, 권역별 해외 주요 국가들의 코로나 이후 국제문화교류진흥을 대응 정책 추진 동향을 분석한다. 주요 권역별 주요 국가들의 코로나 이후 국제문화교류 를 위한 정책변화 동향 파악한다.

- 다섯째, 국제교류 등 다자간 교류·협력 동향을 파악한다. 코로나 19 이후 문화 관련 주요 국제기구의 국제문화교류 활동 동향을 검토한다.

- 여섯째, 국제문화교류 확대를 위한 정책과제 등을 제언한다. 코로나 19 이후 일상화된 비대면/쌍방향 국제문화교류의 흐름을 주도하기 위한 정책 대안을 제시한다. 


\section{2. 연구방법}

\section{가. 문헌연구}

- 관련 논문 및 연구자료 검토 : 국제문화교류, 국제교류, 문화정책, 코로나 대응 관련 연구 논문 및 정책보고서 검토

- 국제기구 관련 동향 및 보고서 검토 : 코로나 전후 문화 및 국제문화교류 관련 문화관련 국제기구들의 동향 및 보고서 검토

- 권역별 주요국 정책동향 검토 : 코로나 이후 지역적 상황을 고려하여 주요 국가 들의 문화관련 대응 정책 동향 자료 검토

\section{나. 설문조사}

- 국제문화교류분야, 문화예술분야, 국제교류분야 전문가, 공공기관 국제문화교 류 담당자 등 100 인 전문가 조사

- 코로나 이후 국제문화교류 관련 사업 추진 동향 및 정책제안 등에 대한 의견 수렴

\section{다. 자문회의 및 면담조사}

- 문화체육관광부 산하 기관 담당자, 연구자, 국제문화교류 사업 참여 경험자를 대상으로 자문 및 면담 진행 


\section{3. 연구수행체계}

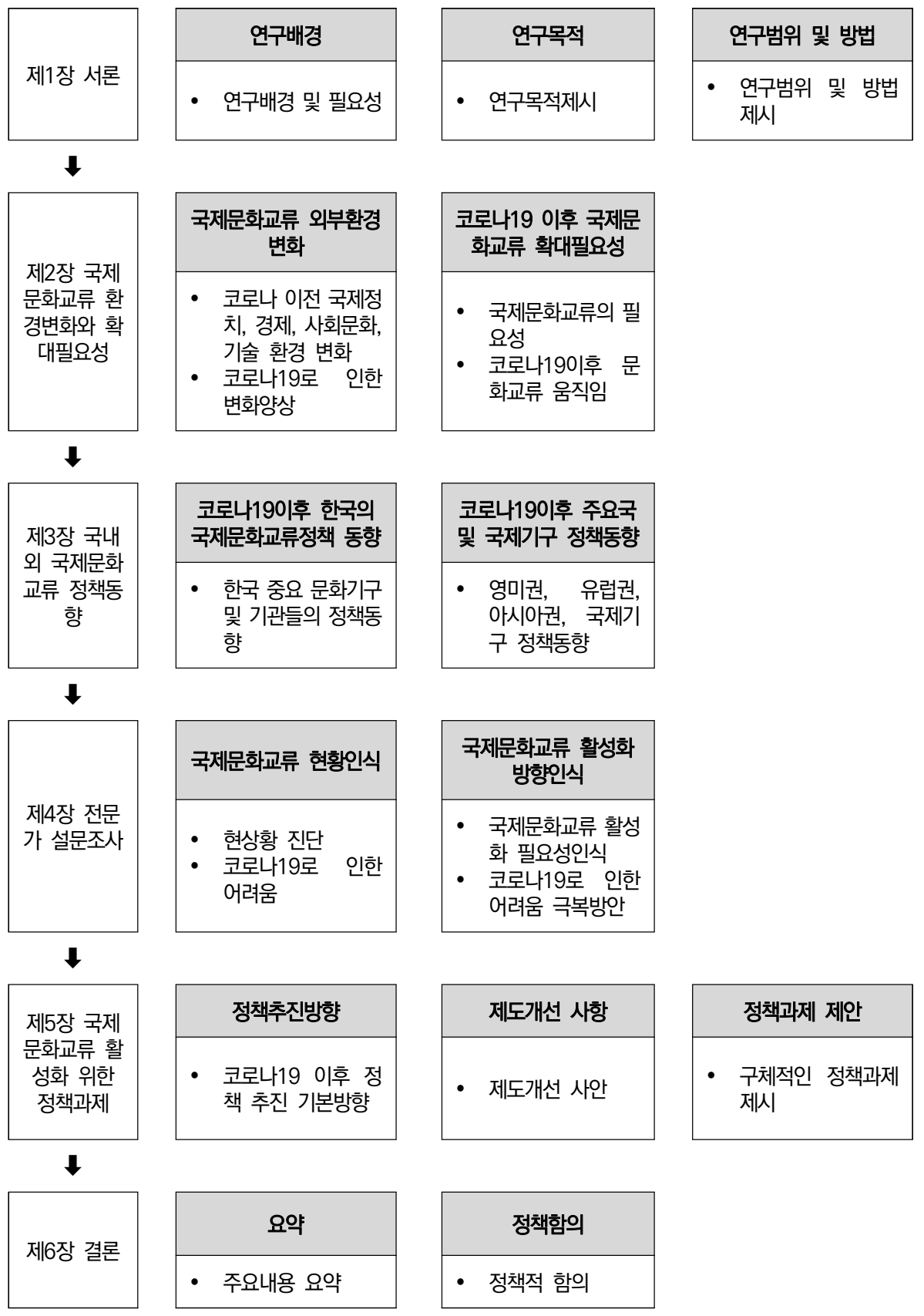



코로나19 이후 국제문화교류 활성화방안 연구

제2장

국제문화교류 외부 환경 변화 



\section{제1절 국제정치 환경}

\section{가. 미.중 경쟁}

미국과 중국의 대결은 코로나 19 이전 시기부터 진행되어온 사안이다. 이는 대략 2000년 대 후반부터 G2(Group of 2)라는 용어가 빈번하게 사용되어 왔다는 점을 통해 알 수 있다. 냉전 해체 후 90년대 동안 미국의 독자적 우위가 지속되다가, 2000년대 들어서 중국이 개혁개방이후 경제발전을 통한 국가역량 강화에 기반하여 새로운 외교 전략을 추구하기 시작하였다. 미국과 중국은 2005년 처음으로 전략대화를 시작했고, 2006년부터 는 마중 전략경제대화로 이름을 바꾸어 추진했다. 미국과 중국은 2009년 4월 G20 정상회 의에서 " 21 세기에 적극적·협력적·전면적 관계"를 수립하기로 합의하고 기존의 고위급 대화와 경제전략 대화를 결합하여 '제1차 전략경제대화'를 출범시켰다.5)

마중간의 경쟁이 본격화 된 것은 중국의 GDP가 미국 다음의 세계 2 위 경제대국으로 부상한 2010년경이다. 중국이 미국에게 '신형대국관계(新型大國關倸'를 요구하면서 시 작되었다. 2010년 5월 다이빙궈(戴秉國) 당시 외교담당 국무위원이 제2차 미.중 전략경 제대화에서 처음으로 '미국과 중국은 상호존중과 협력을 바탕으로 신형대국관계를 열어 야 한다.'고 언급했다. 그리고 시진핑(⿱⿰习习⿱㇒日⿴囗十近平) 주석이 부주석 시절인 2012년 2월 오바마 대통령과의 회담에서 재차 언급했다. 신형대국관계 구축은 중국의 국력이 증대한 만큼 국제관계를 다루는 데 있어 중국의 역할을 인정하라는 것이다. 즉, 과거 냉전 시대 미국 이 소련의 동유럽을 비롯한 일부 국가들(북한, 쿠바)에 대한 영향권을 인정했듯이 중국 의 영향권도 인정해달라는 의미이다.6) 미국은 이러한 중국의 요구를 자국의 패권에 도 전하는 것으로 간주하고 중국 견제를 시작했다. 트럼프 행정부는 중국을 경제(무역제재), 정치(대만과의 관계 증진 및 홍콩보안법 비판), 군사(항행의 자유작전, 연합군사훈련 및

5) 유현석. 2021. 「국제정세의 이해」한울엠플러스, pp. 82-83

6) Allison, Graham. 2020. "The New Spheres of Influence, Sharing the Globe with Other Great Powers." Foreign Affairs, Vol. 99, No. 2, pp. 7-8. 
군사력 증강), 인권(티베트와 신장위구르지역) 등의 분야에서 전 방위적으로 압박했다.

중국은 개혁개방 정책을 추진한 이래 급격한 경제성장을 경험하면서 자신감에 충만한 대외정책 태세로 전환하고 있다. 실력을 감추고 조용히 힘을 키운다는 “도광양회(轁光養 䀲)' 태세를 벗어나 이제는 국제정치의 핵심 행위자로서 미국과 충돌하는 양상이 잦아지 고 있다. 중국의 급격한 부상은 마.중관계의 변화를 추동하는 주요인으로서 마.중 관계를 넘어 국제질서의 근본적 변화를 예고하고 있다. 미국은 제 2 차 세계대전 이후 구축된 미 국 중심의 규칙을 지속하려는 반면, 중국은 기존의 질서를 벗어나 자국 중심의 새로운 규칙을 창출하려고 미국의 질서에 도전하고 있는 것이 마중 패권 경쟁의 본질이다.7)

중국은 경제성장을 바탕으로 군사력 증강에도 박차를 가하고 있다. 항공모함 및 이를 지원하는 잠수함과 구축함 건조에 많은 예산을 투입하고 있으며, 최근에는 핵추진 항공 모함 건조도 계획하고 있을 정도로 중국 군사력의 증강과 현대화 속도는 바르다. 중국의 국방비 예산은 2011년 이후 매년 두 자리 숫자로 증가하고 있으며 2015년의 약 8890 억 위안에서 2020년에 1조 2680억 위안으로 늘어났다. 2011년에 비해 두 배 이상 증 가한 것이며 2017년 이후 매년 7 8\%씩 증가한 것이다.8) 또 중국은 서태평양 동중국해 에서 대만을 압박하고 있고, 일본과는 센카쿠 열도 영유권을 놓고 해양영토분쟁에 적극 적으로 나서고 있으며, 남중국해 내해화를 위해 '남해구단선(nine dash line)'을 명분으 로 베트남 및 필리핀과도 해양영토분쟁을 벌이고 있다. 중국은 아세안 연안국들의 반발 에도 불구하고, 남중국해에 인공섬 7개를 건설하여 군사기지화 하였다. 중국은 태평양을 넘어 인도양에도 해군력을 진출시켜 영향력 확대를 추진하고 있다. 중국은 2018년 12 월 해적퇴치를 명분으로 구축함과 보급함 각 1 척을 인도양에 파견하면서 인도양에 처음 으로 진출했고, 이후 중국 전함의 아프리카 및 중동방문이 잦아지고 있다. 중국은 자국 의 지속적인 경제발전을 위해 에너지의 안정적 수급이 필요하기 때문에 인도양을 드나 드는 자국의 유조선을 보호하고 동시에 중동에 파견된 노동자들 보호를 목적으로 인도 양에 전함을 파견하는 것이라고 주장한다.9)

이러한 중국의 행태에 대하여 미국은 트럼프 행정부시기 2017년 12월 「국가안보전 략보고서」를 통해 중국을 '전략적 경쟁자'로 규정했다. 미국은 2017년 이후 2018년 「국

7) 이상현 외. 2020.「미.중 패권시대 한국의 대외전략」세종연구소, pp. 12-13

8) 유현석. 2021. 「국제정세의 이해」 한울엠플러스, p. 85

9) 이대우. 2020. “제2장 미국의 세계전략과 중국”「미중 패권시대 한국의 대외전략」(이상현 외) 세종연구소, pp. $76-77$ 
방전략 보고서」, 「핵태세 보고서」, 2019년 국방수권법, 그리고 2019년 6월 「인도-태평 양 전략보고서」 등을 통해 중국을 견제하기 위한 군사적 준비태세를 강조해왔다.10) 이 러한 미국의 대중국 정책 기조는 바이든 행정부에서도 지속되고 있다.

\section{나. 다자주의 축소와 자국 중심주의 확산}

80년대 이후 본격화되었던 세계화(Globalization)는 많은 국가들에게 이익과 경제적 번영을 선사했지만, 그와 반대로 다른 국가들에게는 많은 어려움과 경제적 빈곤을 경험 하게 만들기도 하였다. 세계화 질서를 뒷받침 해온 세계무역기구(WTO) 등의 활동에 더 이상 힘이 실리지 않게 되었다. 이는 2008년 글로벌 금융위기 이후 본격화되었다. 전 세계 국가들을 대상으로 하는 WTO, 뉴라운드(New Round), 유엔기후변화협력 (UNFCCC) 등과 같은 다자주의 채널이 급격히 약화되고 있다.11) 세계화 질서 속에서 지역 경제 블록의 형성과 이를 기반으로 한 자유무역이 활발하게 진행되었었다. 하지만, 이제는 지리적으로 인접한 국가 간의 지역블록 움직임도 붕괴 조짐이 일고 있다. 영국의 브렉시트(Brexit)가 진행되어, 유럽연합의 틀이 흔들리게 되었다. 그리스, 이탈리아, 포 르투갈 등 유럽연합 체제하에서 큰 경제적 이익을 얻지 못한 국가들을 중심으로 비슷한 논의가 좀처럼 사라지지 않고 있다. 북미자유무역협정도 한 차원 낮은 미국·멕시코·캐나 다 협정(USMCA)으로 재탄생했다. ${ }^{12)}$

냉전시대 미국은 유엔을 비롯한 국제기구와 다자협력의 제도화를 통해 전쟁을 예방하 고, 협력적 안보를 실현하고자 노력했다. 1990년대 초, 동맹과 진영 대결로 점철되었던 냉전체제 붕괴 이후, 미국은 평화와 안보 등 국제 공공재를 공급하고 글로벌 가치사슬을 유지해오다가 자국 이익 우선주의를 선언하며 신고립주의를 주창하게 되었다. 이러한 미 국의 신고립주의 경향은 트럼피즘(Trumpism)이 대변한다. 트럼피즘은 2008년 세계 금 융위기 이후 미국의 위상 하락과 중국의 급속한 부상에 대한 우려, 그리고 민족주의적 반감을 근본적인 동기로 깔고 있다.

영국의 브렉시트(Brexit)도 비슷한 흐름이다. 자국의 어려움을 유럽통합의 효과로 책 임을 전가하고, 화려했던 대영제국에 대한 향수를 자극해 영국을 유럽통합으로부터 이탈

10) 유현석. 2021. 「국제정세의 이해」한울엠플러스, pp. 86-87

11) 한상춘. 2019. 「또 다른 10년이 온다: 2020-2030 경제의 미래」한국경제신문, p. 31

12) 한상춘. 2019. 「또 다른 10년이 온다: 2020-2030 경제의 미래」한국경제신문, p. 32 
하게 선동한 결과가 바로 브렉시트였다.13) 영국 국민들은 종교적·문화적으로 다른 이민 자 수용에 상당한 불만을 갖고 있었다. 영국 내 이민자 규모는 2014년 당시 약 63만 명에 달했고, 이민자 복지지출에 따른 재정압박과 노동시장의 경쟁심화로 반이민자 정서 가 만연해 있었다. 영국은 EU에 속해 있음으로써 수용해야 하는 이민자 문제뿐만 아니 라, 과도한 $\mathrm{EU}$ 분담금을 지불함에도 상대적으로 $\mathrm{EU}$ 내 위상이 약하다고 인식했다.14) 2016년 6월 국민투표를 통해 영국의 EU 탈퇴가 결정되었다. 이후, 영국이 공식적인 탈 퇴 의향서를 $\mathrm{EU}$ 에 제출했고, 리스본 협정 50 조에 의거하여 다른 $\mathrm{EU}$ 회원국들과의 2년 에 걸쳐 관세, 국가 간의 이동 등 전반적인 사항에 대한 협상이 진행되었다.15) 이 같은 미국우선주의(America First)와 영국우선주의(Britain First)는 내부의 실패를 외부의 탓으로 돌리기 위해 배타적인 민족주의를 적극적으로 동원한 극우 포퓰리즘의 전형적인 사례들이다. ${ }^{16)}$

미국과 영국 이외에도 유럽 지역 전반에 걸쳐 북아프리카와 중동 지역의 난민과 이민 자들의 수 증가로 인하여 사람들은 자신들의 공동체에 대한 불안감을 형성하게 되었고, 이를 활용한 극우 포퓰리즘 정당들이 2010년 이후 큰 지지를 획득 하는 등 자국 중심주 의 경향이 전반적으로 강화되고 있는 추세이다. 유럽 극우 포퓰리즘 정당들은 난민유입, 부채급등 같은 거대 위기를 겪을 때 마다 이를 활용하여 그 세력을 키워왔다. 독일 $\mathrm{AfD}$, 오스트리아 자유당, 네덜란드 자유민주당, 스웨덴 민주당, 이탈리아 동맹당 등 거의 모 든 유럽의 주요 국가들에서 극우 포퓰리즘 정당들이 등장하여 그 세력을 키워왔다.

2011년 리비아 내전과 시라아 내전 장기화 등 중동 지역의 민주화 혁명이 일고, 이에 따른 사회 혼란으로 유럽 난민 신청이 증가하였다. 그런데 특정 국가에 난민신청자가 몰리면서 난민수용정책과 이동 문제를 시작으로 $\mathrm{EU}$ 내 갈등이 일어나기 시작했다. $\mathrm{EU}$ 는 공동이민망명정책으로 '더블린 규정'을 두었는데 이는 $\mathrm{EU}$ 내 망명신청 접수를 한 국가(도 착 국가)에서만 가능하다는 원칙이다. 초기 다수의 난민 유입이 있던 이탈리아는 계속되는 난민을 받아들일 수 없어 이들에게 임시 거주증을 발급했고, 솅겐 조약(Schengen Agreement)에 따라 튀니지 출신 다수는 옛 식민 모국이었던 프랑스로 몰려들었다.17)

13) 김준형. 2020.「코로나 $19 \times$ 미국대선, 그 이후의 세계」평단, p. 39

14) 김광석. 2018. 「한 권으로 먼저 보는 2019 경제전망」이지퍼블리싱, p. 50

15) 김광석. 2018. 「한 권으로 먼저 보는 2019 경제전망」이지퍼블리싱, p. 51

16) 김준형. 2020.「코로나 $19 \times$ 미국대선, 그 이후의 세계」 평단, p. 40

17) 한겨레. 2011.4.27. "프랑스.이탈리아 솅겐 협정 개정 추진" 
이 조약은 EU는 유럽 내 자유로운 이동을 담보하는 조약이다. 이 조약은 벨기에, 프랑스, 룩셈부르크 네덜란드, 서독 등 서유럽 5 개국이 체결한 것으로, 협정국 사이 차량과 사람에 대한 국경 검색을 생략하고 비자체계를 통일하는 내용이다. 이 협정은 1990년 협약 (Schengen Convention)으로 격상되었고, 1999년 5월 발효된 암스테르담 조약(Treaty of Amsterdam)에 흡수되어 EU 내 자유 이동을 가능하게 하였다. 그러나 프랑스가 튀니지 난민들의 입국을 거부하면서 이 원칙을 따르지 않으며 갈등이 시작되었다. 난민수용과 국경 통제에 대한 국가별 입장 차가 나뉘면서 $\mathrm{EU}$ 집행위원화는 2011년 국경검문은 불허하 지만, 예외적인 상황에서는 허용한다고 밝히며 갈등을 봉합하였다.

하지만 난민 신청은 계속 증가하였고, 갈등 역시 점점 커졌다. 2015년, 난민신청자 급증으로 $\mathrm{EU}$ 는 난민 할당제와 지원금 등의 정책을 제시하였다. 서유럽 국가(영국, 프랑 스, 독일 등)들은 적극적인 수용을 한 반면, 동유럽 국가들은 개별 국가 안전을 내세우며 반대하였다. ${ }^{18)}$

\section{[그림 2-1] 유럽 망명신청 추이}

(단위: 천 명)

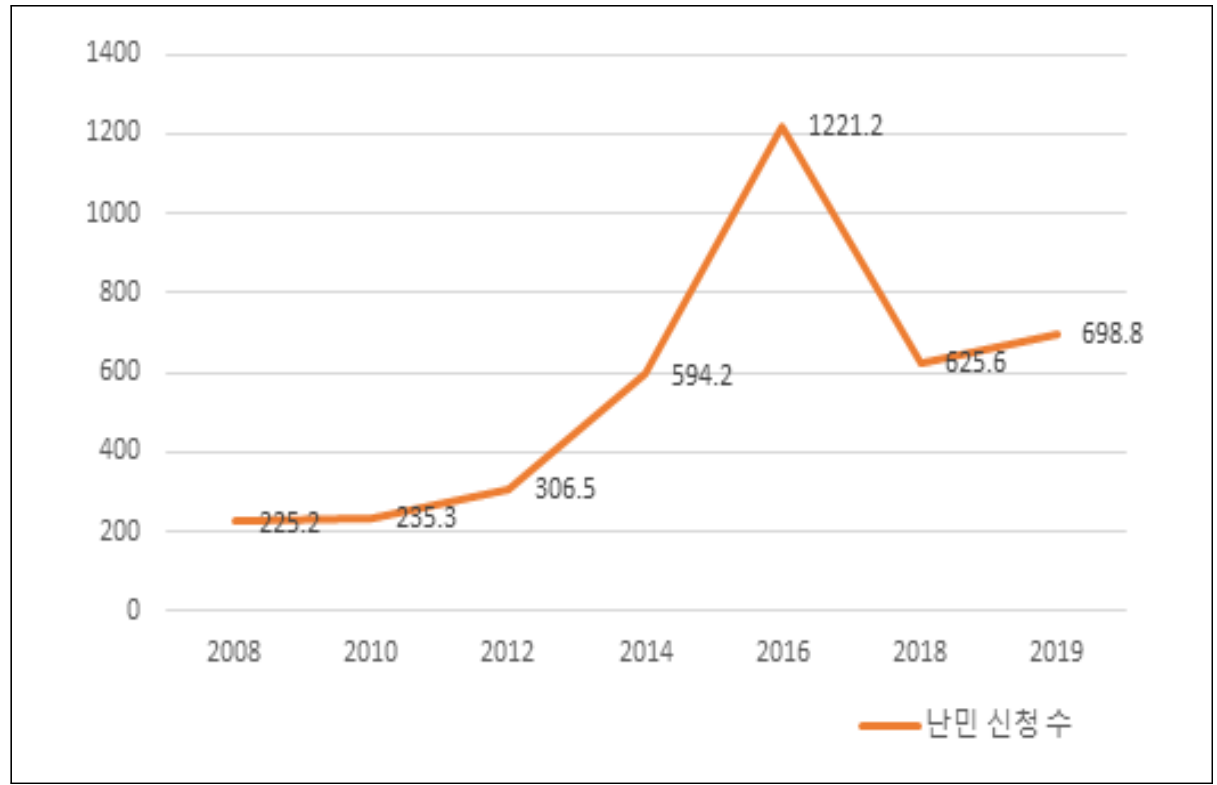

출처: Eurostat, Asylum Statistics ${ }^{19)}$

18) 오정은. 2016. 「난민사태 이후 유럽공동이민망명정책의 변화」IOM이민정책연구원, pp. 7-9

19) https://ec.europa.eu/eurostat/statistics-explained/index.php?title=Asylum_statistics 
2018년에는 이탈리아가 난민 구조선 아쿠아리우스호 입항을 거부하자 프랑스 정부가 반(反)인도적이라며 비난을 했고, 양국 간 외교 마찰이 생겼다. 독일 내에서도 난민 수용 에 대한 반대가 커지면서 난민 수용 문제가 EU 정상회의에서 다뤄지게 되었다.20) 이런 가운데 프랑스 파리와 니스, 스페인 바르셀로나 등 유럽 곳곳에 급진 이슬람 테러가 연 쇄적으로 일어났다. 난민 증가로 유럽 내 무슬림 인구가 확대되었고, 이들을 사회적 위 험 요소로 받아들이면서 헝가리, 폴란드, 체코, 슬로바키아 등의 동유럽 뿐 아니라 이탈 리아, 오스트리아, 프랑스, 네덜란드, 독일, 핀란드에서도 반(反) 이슬람-난민정책을 내 세운 극우정당 득세로 이어졌다.21)

국제통화질서에서는 미국 이외 국가들의 탈달러화 조짐이 있었다. 기축통화국의 과도 한 특권, 국제 불균형 조정 매커니즘의 부재, 과다 외화보유 부담 등이 심해지면서 탈달 러화 조짐이 빨라지는 추세이다. 국제금융기구의 분화 움직임도 뚜렷하다. 중국판 IMF 인 긴급외환보유기금(CRA)이 조성됐고, 유럽판 $\mathrm{IMF}$ 인 유럽통화기금 창설도 검토되고 있다. 2차 대전 이후 미국이 주도해온 세계은행(World Bank)과 아시아개발은행(ADB) 에 대항하기 위해 중국 주도의 신개발은행(NDF)과 아시아인프라투자은행(AIIB)이 설립 됐다.22) 각국의 보호주의에 따른 '글로벌 가치사슬(Global Value Chain)'의 붕괴조짐 은 세계 경제의 앞날에 가장 큰 변수로 작용할 가능성이 높다. 글로벌화가 본격적으로 진행된 1990 년대 이후 세계 교역 증가율과 글로벌 가치사슬 간의 상관계수를 추정해보 면 ‘0.85’에 이를 만큼 높게 나온다. 마중 간 마찰과 한일 간 경제보복 등이 잇따라 발생 하면서 세계교역 탄성치는 경기침체를 가져오는 ' 1 ' 아래로 떨어지고 있다.23)

20) 한국경제신문. 2018.6.17. “난민문제가 EU 분열 불씨...포용 내세운 독일서도 내부갈등”

21) 최익재. 19.5.4. “반난민' 극우파들 뭉쳤다... '우향우'로 기우는 유럽의회.” 중앙SUNDAY. https://news.joins.com/article/23458637

22) 한상춘. 2019. 「또 다른 10년이 온다: 2020-2030 경제의 미래」한국경제신문, p. 33

23) 한상춘. 2019. 「또 다른 10년이 온다: 2020-2030 경제의 미래」한국경제신문, p. 44 


\section{제2절 경제 환경}

\section{가. 경제적 양극화와 구조적 경기침체}

세계경제가 2008년 금융위기 이후 상당한 경기 침체 상황에 처해있다. 이로 인해 경 제적 양극화가 심화되는 상황으로 이어지고 있다. 2008년 금융위기 이후 지속되어온 저 금리 상황 속에서 통화량의 증가와 함께 물가상승 등으로 인한 부작용으로 양극화의 심 화가 벌어지고 있는 것으로 보인다. 세계 경제에서 2010년부터 2019년까지 '총 요소 생산성(Total Factor Productivity, TFP)'은 겨우 0.7\% 늘어났다. 2007년 이후 미국. 영국·독일·프랑스-일본에서 성장이 감소한 원인의 $80 \%$ 가량은 인구통계학 상의 변화에 있다. 특히 노동 가능 인구의 증가세가 부진하거나, 줄어드는 현상이 생겼고, 이로 인해 생산성이 감소했기 때문이다.24) 2009년 이래 중앙은행의 대차대조표상 자산은 4조 달 러 이하에서 16 조 달러 이상으로 폭증했다. 게다가 금리는 크게 떨어졌다.25)

경기 변동과 관련해서, 디지털 경제 등장이나 바이오와 관련된 지적재산권 보호가 중 요해지고, 자금조달 제약으로 신규기업들의 시장진입이 어려워졌다. 저금리로 한계기업 퇴출이 지연되면서 경제 전체 생산성이 떨어졌다.26) 금융위기 이후 제조업 수익성이 하 락했고, 세계 교역량 증가율은 2017년 5.7\%에서 2018년 3.6\%, 2019년 1\% 안팎으로 떨어졌다.27) 제조업 중심의 경기침체는 중국을 비롯해 대만, 홍콩, 싱가포르의 성장에도 부정적인 영향을 미치고 있다. 한국과 대만은 2017년 3\%를 상회하는 성장률을 보였으 나 2019년은 2\%, 홍콩과 싱가포르는 $0.5 \%$ 수준으로 하락하였다. 28$)$

24) 다니엘 슈텔터. 2020.「코로노믹스」더숲, p. 22

25) 다니엘 슈텔터. 2020. 「코로노믹스」더숲, p. 23

26) 강현주. 2020. 「이슈보고서: 한국 경제의 장기추세와 코로나 19」 자본시장연구원, p. 7

27) 한겨레. 2020.1.1. "신 3저 시대를 사는 법"

28) 강현주. 2019. 「이슈보고서: 최근 대내외 요인의 국내 경기하락에 대한 영향력 평가 자본시장연구원, pp. 4-5 
〈표 2-1〉역내 주요 수출국 성장률 추이

(단위: \%)

\begin{tabular}{c|c|c|c}
\hline 국명 & 2017 & 2018 & 2019 \\
\hline 홍콩 & 3.8 & 3.0 & $0.3(2.9)$ \\
\hline 싱가포르 & 3.7 & 3.2 & $0.5(2.5)$ \\
\hline 태국 & 4.0 & 4.1 & $3.0(3.9)$ \\
\hline 대만 & 3.1 & 2.6 & $2.0(2.4)$ \\
\hline 한국 & 3.2 & 2.7 & $2.0(2.6)$ \\
\hline
\end{tabular}

주: 2019년 ( )수치는 2018년 10월 IMF 전망치

출처: 강현주(2019). p.5 재인용

한국 역시 저성장 현상이 나타났다. 한국의 경제성장률은 2008년 글로벌 금응위기 이후, 상당한 수준으로 둔화된 모습이다. 금융위기 이전에는 5\%대를 상회하는 경제성장 률을 기록했으나, 이후에는 3\%대를 넘지 못하는 지지부진한 흐름이다.29) 한국은행에 따르면 2018년 1인당 국민총소득(GNI)은 3만 1,349달러로 전년 2만 9,745달러보다 $5.4 \%$ 올랐다. 이에 따라 1 인당 국민총소득은 2006년 2만 달러를 처음 돌파하고 12 년 만에 3만 달러 고지를 넘어섰다.30)

〈표 2-2〉 소득 5분위별 가구소득 평균 및 점유율

(단위: 만원, $\%, \% \mathrm{p}$ )

\begin{tabular}{c|c|c|c|c|c|c|c}
\hline \multicolumn{2}{c|}{ 구분 } & 전체 & 1분위 & 2분위 & 3분위 & 4분위 & 5분위 \\
\hline 가구소득 & 2014년 & 4,770 & 864 & 2,355 & 3,896 & 5,792 & 10,938 \\
\hline & 2018년 & 5,828 & 1,104 & 2,725 & 4,577 & 6,977 & 13,754 \\
\hline \multicolumn{2}{c|}{ 증감율 } & $23 \%$ & $28 \%$ & $16 \%$ & $18 \%$ & $21 \%$ & $26 \%$ \\
\hline
\end{tabular}

출처: 통계청 가계금융복지조사

한국 경제에서 경제양극화 현상은 수출과 내수의 양극화, 산업과 기업간의 양극화, 고 용 및 소득의 양극화 등으로 나누어 볼 수 있다. 2002년 이래 수출은 높은 증가세를 보여왔으나, 민간소비와 투자는 2003년 이후 부진한 상태를 지속하고 있다. 산업 간의 양극화도 IT 산업과 비IT 산업 간의 양극화가 두드러지게 지속되었다. 2003년 이후

29) 김광석. 2018. 「한 권으로 먼저 보는 2019 경제전망」이지퍼블리싱, p. 78

30) 김우진. 2020. "26장. 코로나19 이후 사회 양극화와 주택시장”「포스트코로나 대한민국: 집단지성 27인 의 성찰과 전망」(이영환 외) 한울엠플러스, p. 377 
GDP 중 IT 산업의 비중이 $10 \%$ 를 넘어선 이래 그 비중은 지속적으로 증가해왔다. 반도 체, 무선통신기기, 자동차, 컴퓨터, 선박 등의 품목이 2003년경부터 수출의 45\%의 비중 을 넘어섰다. 이러한 IT 산업의 성장에 비추어 서비스산업의 경우 그 상대적 생산성이 지속적으로 하락하였다. 대기업과 중소기업간의 격차도 줄지 않고 지속적으로 증가해왔 다. 산업간기업 간 양극화는 자연스럽게 노동자들 간의 소득 양극화로 이어져 사회전반 의 양극화 현상으로 심화 되어왔다.31)

양극화가 심해지는 상황에서 2008년 금융위기 이후 글로벌 경기침체 상황에서 한국 의 경제도 저성장을 지속하는 상황이었다. 2016년 3월 6일 전경련 발표에 따르면, 2010년 1분기 20.4\%까지 올랐던 노동생산성 증가율은 2012년 4분기 $1.2 \%$ 를 기록한 이후 마이너스대로 하락해 2015년 3분기까지 11분기 연속 $0 \%$ 이하의 증가율을 보여왔 다. 제조업 평균 가동율 또한 2011년 80.5\%를 기록한 이래 4년 연속으로 하락해 2015 년 $74.2 \%$ 까지 떨어졌다. 32$)$

[그림2-2] 실질 국내총생산과 실질 국민총소득 증가율 추이33)

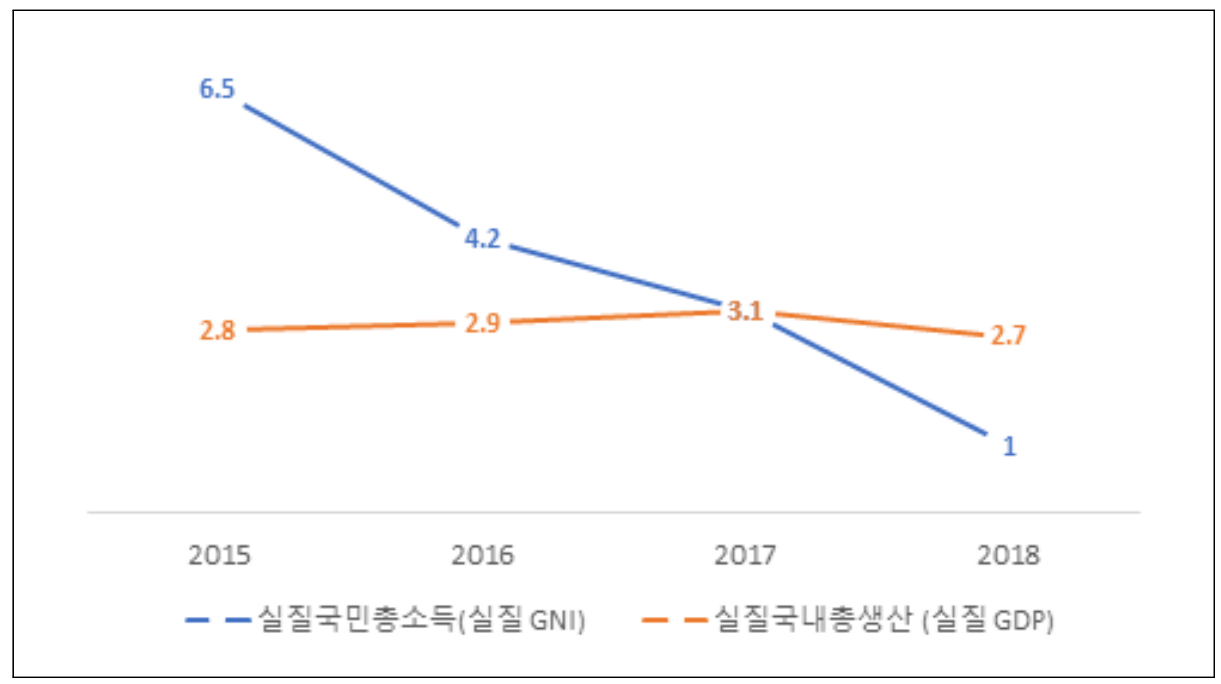

한국의 실질임금 상승률도 2000년대 4\%를 넘었지만 2011년 이후 평균 $1 \%$ 미만의 상승에 머무른 것으로 나타나 고용의 질이 높아지지 않았다.34) 한국은행에 따르면

31) 한준경. 2006. “한국경제의 양극화 원인과 영향 및 정책과제" 「사회과학논총」Vol.8, pp.483 504.

32) 연합뉴스. 2016.03.06. “구조적 장기침체 빠진 한국경제... 10대 지표 올 마이너스."

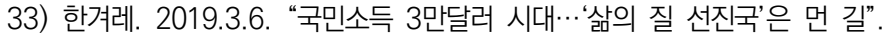


2018년 1인당 국민총소득(GNI)은 3만 1,349달러로 전년 2만 9,745달러보다 $5.4 \%$ 올 랐다. 이에 따라 1 인당 국민총소득은 2006년 2만 달러를 처음 돌파하고 12 년 만에 3 만 달러 고지를 넘어섰다.35) 그러나 국민총소득의 근간인 명목 국내총생산은 IMF(-1.1\%) 이후 최저인 $3 \%$ 였다. 수출물가보다 수입물가가 더 올라 국민총소득 증가율도 글로벌 금 융위기 때(0.1\%) 이후 가장 $1 \%$ 증가세를 보였다. 그 결과 개개인이 벌어들인 실질소득 은 2015, 2016년 때보다 줄어든 것이다.36) 2020년 가계금융복지조사에 따르면, 가구 의 순자산은 늘어났지만, 소득 증가율에 비해 부채 비율이 늘어났고 근로소득과 사업소 득비중이 각각 $0.9,0.8 \% \mathrm{p}$ 감소하였다. 2018년에 비해 소득 5분위별 가구소득이 증가 하기는 했지만, 큰 차이가 전년과 큰 차이가 없다. 상대적 빈곤율은 $16.3 \%$ 로 나타났다. 이러한 지표는 저성장, 저출산, 생산가능 인구 감소, 성장잠재력 둔화 등의 이슈들과 더 불어 '고용 없는 경제' 임을 보여주었다.37)

〈표 2-3〉 가구의 경제상황

(단위: 만원, \%, \%p)

\begin{tabular}{c|c|c|c|c|c}
\hline \multicolumn{2}{|c|}{ 구분 } & 순자산(A-B) & 자산 (A) & 부채 (B) & 소득 \\
\hline \multirow{2}{*}{ 가구소득 } & 2019년 & 35,281 & 43,191 & 7,910 & 5,828 \\
\cline { 2 - 6 } & 2020년 & 36,287 & 44,543 & 8,256 & 5,924 \\
\hline & 증감율 & 2.9 & 3.1 & 4.4. & 1.7 \\
\hline
\end{tabular}

출처: 통계청, 2020 가계금융복지조사

〈표 2-4〉 소득 5분위별 가구소득 평균 및 점유율

(단위: 만원, \%, \%p)

\begin{tabular}{c|c|c|c|c|c|c|c|c}
\hline \multicolumn{2}{c|}{ 구분 } & 전체 & 1분위 & 2분위 & 3분위 & 4분위 & 5분위 & 증감율(\%) \\
\hline \multirow{4}{*}{ 가구소득 } & 2014년 & 4,770 & 864 & 2,355 & 3,896 & 5,792 & 10,938 & - \\
\cline { 2 - 9 } & 2018년 & 5,828 & 1,104 & 2,725 & 4,577 & 6,977 & 13,754 & 23 \\
\cline { 2 - 9 } & 2019년 & 5,924 & 1,155 & 2,763 & 4,671 & 7,126 & 13,903 & 1.7 \\
\hline
\end{tabular}

출처: 통계청, 2020 가계금융복지조사

이러한 일자리 악화와 소득 불평등은 다시 소비 불평등으로 이어지는 경제적 양극화

34) 이근태. 2014. ‘LGERI 리포트: '성장 없는 고용', 고용 없는 저성장의 경고등」 LG경제연구원 p. 13

35) 김우진. 2020. “26장. 코로나19 이후 사회 양극화와 주택시장”「포스트코로나 대한민국: 집단지성 27인 의 성찰과 전망」(이영환 외) 한울엠플러스, p. 377

36) 한겨레. 2019.3.6. “국민소득 3만달러 시대... '삶의 질 선진국'은 먼 길"

37) 김광석. 2018. 「한 권으로 먼저 보는 2019 경제전망」이지퍼블리싱, p. 14 
를 심화하였다. 통계청이 발표한 2019년 연간지출 가계동향조사에 따르면, 소득 1 분위 가구 월평균 소비지출은 102 만 4 천원, 소득 5 분위 가구는 422 만 1 천원으로 나타났다. 소득 1 분위 가구가 식료품과 주거에 주요 소비를 하는 반면, 소득 5 분위 가구는 음식·숙 박에 가장 많은 소비지출을 하고 있어 소비 양극화를 보였다. 2019년 소비생활지표조사 에 따르면, 가계소득 증감인식(가구 소득이 증가·감소했는지에 대한 주관적인 인식)이 $1.2 \%$ 로 소득 감소보다 증가율을 크게 인식하는 것으로 나타났지만, 소득계층 인식 별로 는 상류층이 $27.5 \%$, 중산층은 $3.7 \%$, 하류층은 $-18.2 \%$ 로 소득 인식 격차가 났다. 동시 에 소비생활 격차지수(주관적으로 인식하는 소비수준 기준으로 양극화 정도 파악하기 위 한 지수)는 최고치를 달했던 2015년(23.9\%)보다는 감소한 7.7\%로 나타났다. 여성, 60 대 이상, $1 \cdot 2$ 인 가구, 소득 300 만원 미만의 경우 양극화를 크게 느끼고 있었다.38)

\section{나. 디지털 경제 확산}

2000년대 이후 본격적으로 개인의 경제활동과 기업의 영리 활동에 있어서 서비스의 품질 개선과 경영효율화를 위하여 디지털 기술이 적극 도입되어 왔다. 디지털 경제는 재화와 서비스의 생산, 분배, 소비 등 주요경제활동이 '디지털화되고 네트워크화된 정보 와 지식' 이라는 생산요소에 주로 의존하는 경제를 의미한다.39) 디지털 경제로의 전환은 2000년대 이후 지속적으로 진행되어왔다. 디지털경제의 확산은 단순히 소비의 효용을 증가시키는 차원을 넘어 개인과 기업의 경제활동, 나아가 정치, 사회, 문화의 양식에 근 본적인 변화의 동인을 제공하게 된다.40)

정보와 지식에 대한 수요가 증가하고, 이를 뒷받침하고 수요를 창출하는 디지털 기술 의 발전과 맞물려, 기술에 기반한 글로벌 네트워크화가 급속히 진전되면서, 경제활동의 변화와 정치사회문화적 변화를 추동해내게 되는 것이다. 이 디지털 경제로의 전환은 2000년대 이후 지속적으로 진행되어왔다.

디지털 경제가 지속되고, 디지털 기술을 활용한 구글, 유튜브, 아마존, 페이스북, 알리 바바, 에어비앤비, 네이버, 카카오 등 디지털 플랫폼 기업들이 국내외 경제성장과 산업 성장을 주도해왔다. 이러한 거대 디지털 플랫폼 기업의 성장과 더불어 다양한 디지털

38) 황미진·배순영. 2019. 「2019 한국의 소비생활지표」한국소비자원

39) 이용만·이근태·전종규. 2000. “디지털 경제의 도래와 우리경제에의 시사점." LG경제연구원 보고서. p.1.

40) 이용만·이근태·전종규. 2000. “디지털 경제의 도래와 우리경제에의 시사점." LG경제연구원 보고서. p.2. 
비즈니스 모델들이 등장하였다. 구독경제(Subscription Economy), 클라우드 펀딩 (Crowd Funding), 클라우드 소싱(Crowd Sourcing), 오픈 소스(Open Source) 등의 비즈니스 모델들이 속속 개발되어 경제의 중요한 활력소가 되었다.

[그림 2-3] 디지털 경제 개념의 수직적 분류41)

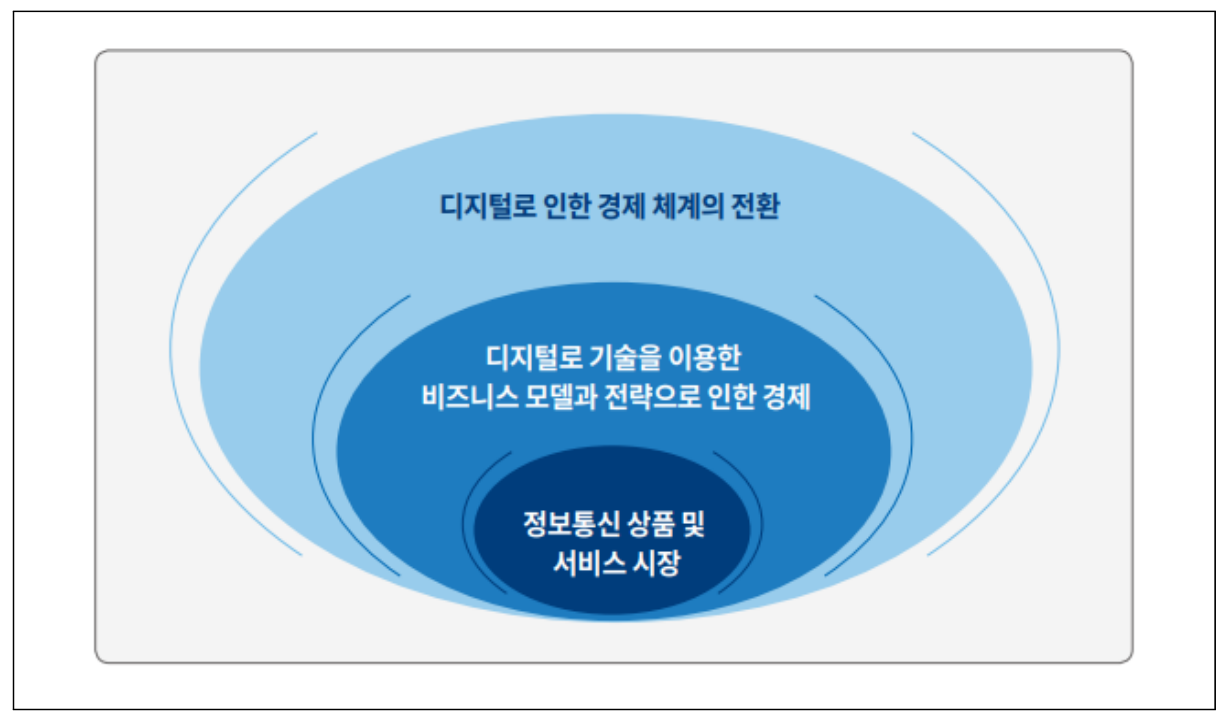

디지털 경제가 지속되고, 디지털 기술을 활용한 구글, 유튜브, 아마존, 페이스북, 알리 바바, 에어비앤비, 네이버, 카카오 등 디지털 플랫폼 기업들이 국내외 경제성장과 산업 성장을 주도해왔다. 이러한 거대 디지털 플랫폼 기업의 성장과 더불어 다양한 디지털 비즈니스 모델들이 등장하였다. 구독경제(Subscription Economy), 클라우드 펀딩 (Crowd Funding), 클라우드 소싱(Crowd Sourcing), 오픈 소스(Open Source) 등의 비즈니스 모델들이 속속 개발되어 경제의 중요한 활력소가 되었다.

2019년 대표적인 산업·기술적 이슈는 디지털 트랜스포메이션(Digital Transformation) 이다. 4차 산업혁명의 기반 기술들이 다양한 산업에 걸쳐 확대 적용되면서, 아날로그식 상품과 서비스가 디지털 기반의 서비스로 대전환되는 현상이 두드러지게 나타났다.42)

41) Bukht, Rumana \& Heeks, Richard(2017). Defining, Conceptualising and Measuring the Digital Economy. Centre for Development Informatics. Global Development Institute, SEED; 윤기영 2021. "디지털경제여 어디로 가시나이까." SPRi 산업동향 p.27 재인용.

42) 김광석. 2018. 「한 권으로 먼저 보는 2019 경제전망」이지퍼블리싱, p. 14 
디지털 트랜스포메이션은 빅데이터, 로봇, 블록체인, 클라우드, 인공지능, 사물인터넷, 가상증강 현실 등 4차 산업혁명의 기반 기술들을 활용하여 기업들이 전략과 비즈니스 모델을 전환시키고, 경쟁력을 강화하는 방향으로 움직이게 한다. 농축산업에서는 스마트 팜을, 제조업에서는 스마트 팩토리를, 유통업에서는 키오스크를 도입하는 것이 대표적인 예다.43) 디지털 트랜스포메이션이 가장 두드러지게 나타나고 있는 산업들 중 하나가 금 융산업이다. 디지털 금융서비스에 대한 의존도가 늘어나면서, 소비자들이 점포방문을 통 한 대면 서비스 수요를 줄여나가고 있다. 금융기업들은 영업지점 및 직원 수를 줄이고 있다.44) 이처럼 다양한 분야에서 디지털 경제의 발전이 지속되어왔다.

43) 김광석. 2018. 「한 권으로 먼저 보는 2019 경제전망」이지퍼블리싱, p. 138

44) 김광석. 2018. 「한 권으로 먼저 보는 2019 경제전망」이지퍼블리싱, p. 139 


\section{제3절 사회문화적 환경}

\section{가. 사회적 불평등과 세대갈등}

한국 사회의 불평등 정도는 2000년대 이후 점차 상승해왔다. 2015년에는 소비 양극 화 지수도 조사 이래 최고치를 달하였고, 하류층 비율도 2013년보다 2배 가까이 증가하 였다. 한국 사회 내에서 자신의 노력으로 사회적 계층의 상승이 가능하다는 인식이 점차 사라지고 있다. 저임금의 비정규직을 양산하는 사회적 체제가 형성되어 자신의 노력으로 신분상승이나 부의 축적이 가능할 것이라고 생각하는 사람들이 감소하고 있다.

[그림 2-4] 19세 이상 국민의 계층이동 가능성에 대한 인식

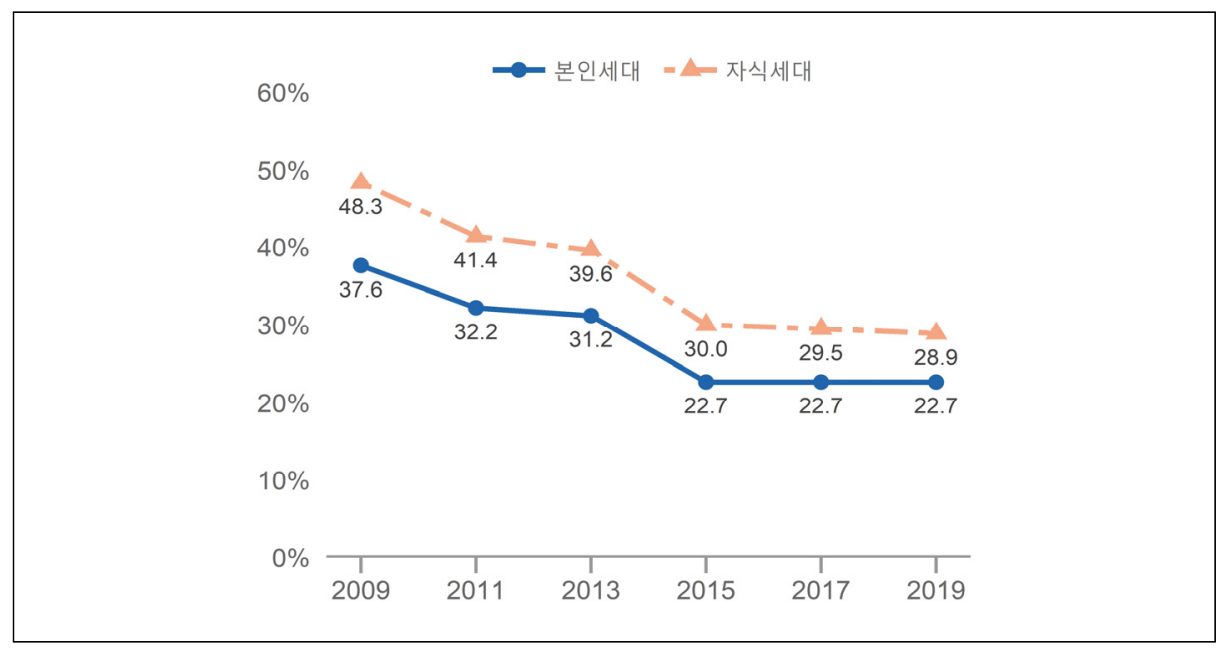

출처: 통계청, "2019년 사회조사결과” 보도자료 
그림에서 보는 바와 같이 2015년 이후 본인세대의 계층 이동 가능성이 인식 $22.7 \%$ 수준으로 유지되고 있고, 다음세대의 계층이동 가능성 인식은 2015년 30\%, 2017년 $29.5 \%, 2019$ 년 28.9\%로 점점 낮아지고 있는 추세이다.

사회전반의 이러한 부정적 인식의 확산 속에서 청년세대들은 여러 가지 경제적 어려움을 겪고 있다. 특히 1980년대 2000년대 초반에 출생한 'MZ 세대’는 경제 성장기, 혹은 풍족한 시기에 태어났지만, 성인기 진입 후 경제 저성장기를 맞아 노동시장 진입의 어려움, 고용불안정, 주거불안, 소득감소 등 경제적 어려움을 겪고 있는 상황이다. 앞선 세대들은 청년 시절의 고생과 어려움 속에서도 취업을 하고 나이를 먹으면서 사회 내의 안정적 계층으로 성숙해 나간 반면에, 현재의 젊은 세대들은 앞선 세대들 보다 더 한 입시와 취업경쟁을 치루면서도 사회경제적산업적 경제구조의 변화 속에서 정규직 취업이 힘들고, 경제적 안정을 갖기 더욱 힘든 상황에 처해있다. 투자은행 크레디트스위스는 '글로벌 부 보고서'(2017)에서 $\mathrm{MZ}$ 세대가 학자금 대출, 대출규제, 집값 상승 등의 문제에 시달리고 있다고 분석했다. 통계청이 발표한 '2016년 기준 일자리 행정통계 결과'에 따르면, 29세 이하의 평균소득이 182 만원으로 60 세 아상 평균소득인 186 만원보다 낮은 것으로 나타났다.

\section{나. 1 인 가구 증가}

2019년 기준 인구주택 총조사에 따르면, 20 대가 전체 1 인가구의 $18.2 \%$ 로 가장 큰 비중을 차지하며, 다음은 30대(16.8\%), 50대(16.3\%), 60대(15.2\%) 등의 순으로 나타났 다. 1 인가구의 거주형태는 1 인가구는 보증금 있는 월세(38.0\%), 자가(30.6\%), 전세 (15.8\%) 순으로 주택 점유형태 비중이 높게 나타난다. ' 18 년 1 인가구 연소득은 전년 대 비 $2.6 \%$ 증가한 2,11 만 원으로 전체 가구보다 $0.4 \% \mathrm{p}$ 더 많이 증가하였으나, 여전히 전체 가구의 $36.3 \%$ 수준이다. 1 인 가구 증가는 결혼에 대한 가치관 변화, 노동시장 진입 어려움으로 인한 비혼과 만혼, 이혼 증가, 고령화와 핵가족화 등 각종 사회경제적 요인 들이 맞물려 있다. 1 인 가구는 여가시간 활용은 전체 인구대비 1.2 배 수준으로 더 많은 여가활동을 하고 있다. ' 19 년 1 인가구과 전체 인구 모두 TV 시청, 휴식, PC게임인터넷 검색 순으로 여가시간을 많이 활용하는 것으로 나타났다. '19년 1 인가구의 하루 평균 여가시간은 전년 대비 0.4 시간 늘어난 4.2시간으로 전체 인구 평균 여가시간 3.5시간의 1.2 배 수준이다. 
[그림 2-5] 1인 가구 비중

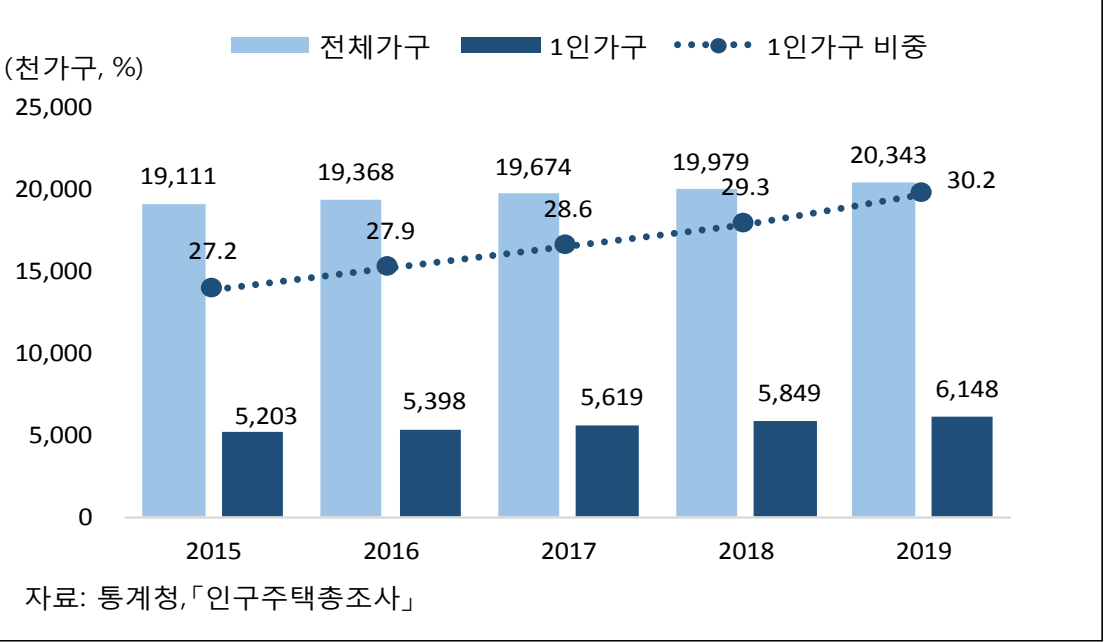

이처럼 1 인가구가 더 많은 여가시간을 활용하고 있는 상황에서 1 인가구로 인한 방송 매체 이용행태의 변화 현상도 나타나고 있다. 1 인가구는 스마트폰 이용시간이 1 시간 50 분으로 다른 가구 유형의 구성원에 비해 가장 많은 것으로 나타났다. 1 인 가구의 TV이 용자 비율(주 5일 이상 이용)은 $70.0 \%$ 로 가장 낮았으며 특히 20대와 30대 이용률이 각 각 44.4\%, 57.4\%로 현저하게 낮은 특징을 보인다. 반면, 스마트폰 이용률(주 5일 이상 이용)은 $73.4 \%$ 로 2 세대 가구원(87.0\%)에 이어 두 번째로 높았으며 스마트폰 이용자의 평균 이용 시간도 1 시간 50 분으로 다른 가구 유형의 구성원에 비해 10 30분 가량 많게 나타났다.

1 인 가구는 TV수상기 보유율에 비해 이용률이 상대적으로 낮은 반면, 데스크탑이나 노트북은 보유율이 낮음에도 불구하고 이를 통한 방송 프로그램 이용률은 상대적으로 높아 TV보다 다른 매체를 활발하게 이용하는 능동적인 시청 집단으로 나타났으며, 20대 가 이러한 트렌드의 주도층인 것으로 판단된다. 45$)$ 이러한 1 인가구의 매체 소비의 행태 는 넷플릭스와 왓챠와 같은 온라인 스트리밍 서비스 플랫폼의 성공과도 일정한 상관성 이 있는 것으로 보여진다.

45) 정용찬. 2017. "1인가구의 매체보유와 이용특성." KISDISTAT Report Vol.17-10. 정보통신정책연구원 
[그림 2-6] 여가활용 및 하루평균 여가시간 비교

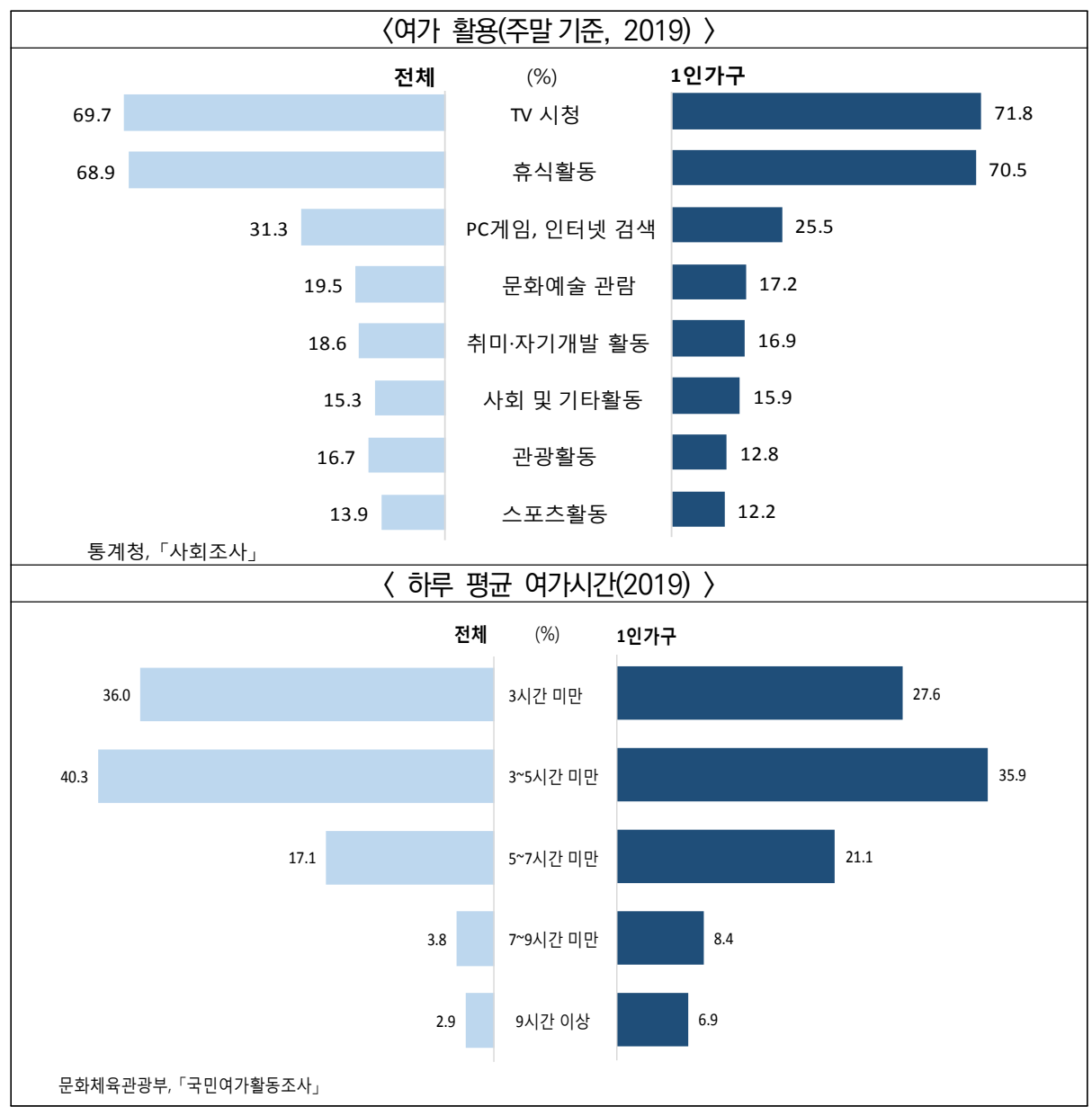




\section{제4절 기술 환경}

\section{가. 4차 산업혁명}

디지털 기술의 발전은 2000년대 이후 지속되어왔다. 최근에는 4차 산업혁명이라는 화두 속에서 급진적인 기술의 발전과 적용이 진행되고 있다. 4차 산업혁명은 로봇 (Robot), 인공지능(Artificial Intelligence), 사물인터넷(Internet of Things, IOT)의 기술융합에 의한 사이버-실물세계(Cyber-Physical) 연계 시스템이 중심이 되는 기술혁 명이다.46) 4차 산업혁명이라는 키워드가 전세계에 공식적으로 등장한 것은 2016년 1월 말 스위스의 한적한 스키 휴양지 다보스에서 개최된 세계경제포럼(World Economic Forum)의 연례총회(다보스 포럼)을 통해서였다. 47 )

4 차 산업혁명은 여러 방식으로 표현할 수가 있지만, 그중 하나를 들자면 디지털-물리적생물학적 와해성 기술(disruptive technology)들이 경계 없이 융합되어, 우리가 살고, 일하고, 노는 거의 모든 면에서 변혁을 가져오는 것으로 말할 수 있다.48) 즉, 유전체 편집(genome editing), 신소재, 휴머노이드 로봇(humanoid robot), 인공지능, 디지털 보안, 빅데이터, 분산제조(distributed manufacturing)와 적층제조(additive manufacturing), 에너지그리드(energy grid) 등의 파괴적 기술들이 융합되어 생물공장, 핀테크, 고성능 로봇, 자율주행, 사물인터넷(internet of things), 서비스인터넷(internet of service) 등이 탄생하고 기존 산업과 생활방식을 획기적으로 바꾸는 것이다. 공유경제, 스마트홈, 개인별 맞춤형 생산, 의료데이터와 유전체 등 개인정보가 결합한 획기적인 헬스케어 시스 템 등 산업과 사회시스템의 변화가 하나씩 우리 곁으로 다가오고 있다.49)

46) 4차산업혁명 융합법학회. 2020. 「4차 산업혁명의 이해」 박영사, p. 17

47) 이상엽. 2020. “코로나 19가 야기한 4차 산업혁명의 가속”「미래의 귀환: 코로나 19와 4차 산업혁명 대전환.(김소영 외) 한울아카데미, p. 17

48) 이상엽. 2020. “코로나 19가 야기한 4차 산업혁명의 가속” 미래의 귀환: 코로나 19와 4차 산업혁명 대전환」(김소영 외) 한울아카데미, p. 19

49) 김소영 외. 2020.「미래의 귀환」한울아카데미, p. 19 
〈표 2-5〉4차 산업혁명의 핵심적 와해성 기술50)들

\begin{tabular}{|c|c|}
\hline 와해성 기술 & 관련 산업을 새롭게 재편하고 시장 대부분을 점유할 파괴력을 가진 혁신적인 기술 \\
\hline 유전체 편집 & $\begin{array}{l}\text { 생명체를 구성하는 유전물질의 총체인 유전체를 다양한 분자생물학적 도구를 이용하여 조 } \\
\text { 작하여 원하는 유전자를 더하고 빼고 변형시킬 수 있는 기술 }\end{array}$ \\
\hline 휴머노이드 로봇 & $\begin{array}{l}\text { 사람의 모습을 가지고 사람처럼 운동하는 로봇으로서, 아직은 갈길이 멀지만 사람과 모든 } \\
\text { 면에서 유사한 기능을 할 수 있는 로봇 }\end{array}$ \\
\hline 분산제조 & $\begin{array}{l}\text { 하나의 대규모 공장에서 제품들을 생산하는 대신, 공간적으로 떨어져 있는 생산기지들을 } \\
\text { 네트워크로 연결하여 시공간 제약을 없애고 탈중앙 방식으로 제조하는 것 }\end{array}$ \\
\hline 적층제조 & $\begin{array}{l}\text { 어떤 물건을 만들 때 보통은 큰 재료를 자르고 깎아내며 만드는 것이 일반적인 방법이었던 } \\
\text { 것에 반하여, } 3 D \text { 프린팅과 같이 재료를 한층 한층 쌓아가며 만드는 것 }\end{array}$ \\
\hline 에너지그리드 & 다수의 에너지 생산자로부터 다수의 소비자까지를 연결하는 네트워크 \\
\hline 핀테크 & $\begin{array}{l}\text { 금융과 기술의 합성으로서 이동통신, 빅데이터, 인공지능 등의 정보통신 기술을 금융시스 } \\
\text { 템에 융합한 기술 }\end{array}$ \\
\hline 사물인터넷 & $\begin{array}{l}\text { 사물들에 센서와 통신 기능을 탑재하고 유무선 인터넷으로 연결하여 사람이 원하는대로 } \\
\text { 혹은 사물 자율적으로 기능 및 작업 조종이 가능한 기술 }\end{array}$ \\
\hline 서비스인터넷 & 정보통신 기반의 다양한 서비스 비즈니스 네트워크 \\
\hline
\end{tabular}

출처: 김소영 외. 2020.「미래의 귀환」 한울아카데미, p. 20

4차 산업에 대해 한국은 국가적으로 대응하고 있다. 2017년 8월 대통령 직속 "4차 산업혁명위원회'를 신설하였고, 정부는 인공지능 소프트웨어, 하드웨어, 데이터·네트워 크 등 분야별 핵심원천 기술 및 이를 활용한 융합기술 개발을 지원하며, 신산업성장을 위한 규제 개선 및 제도 정비를 추진해 나가고 있다.51) 산업단지 내 제조·생산공정에 ICT를 접목한 스마트 공장을 집중 보급할 계획이다. 그밖에도 공공 빅데이터를 구축하 고, 이를 시장에 개방해 빅데이터 기반 산업들을 육성하는 등 산업 전반에 걸쳐 상당한 기회가 있을 것으로 예견되고 있다.52) 4차 산업혁명과 관련된 기술적 변화는 산업구조 전반의 변화와 함께 사회구조와 개인의 사회생활 전반의 변화를 추동할 것이다.

\section{나. 디지털 기술의 발달}

4차 산업혁명을 추동하는 가장 핵심적인 기술 중에 하나가 바로 디지털 기술이다. 디 지털 기술도 2000년대 이후 꾸준히 발전해오면서 사회 생활 전반의 변화를 이끌어내고

50) 와해성 기술(disruptive technology) : 업계를 완전히 재편성하고 시장 대부분을 점유하게 될 신제품이나 서비스

51) 김광석. 2018. 「한 권으로 먼저 보는 2019 경제전망」이지퍼블리싱, p. 156

52) 김광석. 2018. 「한 권으로 먼저 보는 2019 경제전망」이지퍼블리싱, p. 157 
있다. 최근에 와서는 그 발전 속도가 더욱 빨라져, 사회 전반의 변화를 추동하고 있다. LG 경제연구원은 2018 주요 디지털 기술로 인공지능, 자율주행차, 로봇/드론, 스마트 팩토리, 통신 네트워크(5G), 엣지 컴퓨팅, 양자 컴퓨팅, 블록체인, VR/AR, 디지털 헬스 케어를 꼽았다. 인공지능과 자율주행차는 인간처럼 생각하는 '초지능화', 로봇/도론과 스마트팩토리는 '초자동화', 통신 네트워크, 엣지, 양자 컴퓨팅, 블록체인은 '초연결화', $\mathrm{VR} / \mathrm{AR}$ 과 디지털 헬스케어는 '초융합화' 변화를 구체화, 현실화하게 될 것이라고 강조 하였다.53) 초연결사회(hyper-connected)는 인간과 인간, 인간과 사물, 사물과 사물이 마치 거미줄처럼 촘촘하게 네트워크로 연결된 사회이며, 이미 우리는 이러한 초 연결사 회에 진입하였다고 할 수 있다. 전 세계 수십억명이 인터넷에 연결되어 있으며, 디지털 기기의 수는 전 세계 인구수를 뛰어넘은 지 오래다. 인터넷은 24 시간 개방되어 있고, 다양한 기기를 이용해서 여러 정보를 확인하는 일은 이제 전혀 낯설지 않은 모습이다.

〈표 2-6〉 2018 디지털 기술 10대 이슈

\begin{tabular}{|c|c|c|}
\hline \multirow{2}{*}{ 초지능화 } & 인공지능 & 인간처럼 생각하는 지능 \\
\hline & 자율주행 & Level4 완전 자율 주행 실험 \\
\hline \multirow{2}{*}{ 초자동화 } & 로봇, 드론 & 기계장치에서 삶의 동반자로 \\
\hline & 스마트팩토리 & 제조업 업그레이드 경쟁 본격화 \\
\hline \multirow{4}{*}{ 초연결화 } & 통신네트워크 & 5G, 차세대 네트워크 경쟁 \\
\hline & 엣지컴퓨팅 & 클라우드와 엣지 결합 \\
\hline & 양자컴퓨팅 & 큐비트 부상 \\
\hline & 블록체인 & 금융 및 산업 인프라로 활용 \\
\hline \multirow[b]{2}{*}{ 초융합화 } & VR/AR & 실생활, 산업현장으로 확산 \\
\hline & $\begin{array}{l}\text { 디지털 } \\
\text { 헬스케어 }\end{array}$ & 규제 완화가 융복합 모멘텀으로 \\
\hline
\end{tabular}

출처: LG 경제연구원(2018), p. 3 재인용

초연결사회는 사물인터넷(Internet of Things, 이하 IOT)을 기반으로 구현된다. 눈에 보이지 않는 연결망으로 모든 사람과 사물을 연결하고, 심지어 가상공간의 현실도 연결하 여 모든 일상과 경제활동의 풍경을 변화시킨다. 2019년 4월 문재인 대통령도 ‘ $5 \mathrm{G}+($ 플러

53) LG 경제연구원 산업연구부문 미래산업그룹. 2018. 2018 주요 디지털 기술·산업 이슈」 LG 경제연구원 
스) 전략발표회'에서 가까운 미래에 IOT가 국민의 삶을 바꾼다고 강조한 바 있다.54) 2019 년 1월 고척스카이돔에서 열린 워너원 콘서트는 세간의 화제가 되었다. $5 \mathrm{G}$ 기술이 활용되 었다. 무선카메라를 이용하여 $4 \mathrm{~K} \mathrm{UHD} 55$ ) 로 촬영한 영상을 $\mathrm{KT}$ 가 $5 \mathrm{G}$ 로 송출하는 데 성공하였다. 그 덕분에 공연 티켓을 구하지 못한 팬도 실시간으로 공연을 시청하며 즐길 수 있었다. 게다가 가상현실 기술까지 이용하면 마치 실제 콘서트장에 온 듯한 경험도 할 수 있었다.56) 이처럼 ICT와 디스플레이 기술의 발전으로 기존의 스크린과 같은 개념의 $2 \mathrm{D}$ 화면에서 가상현실과 증강현실로 진화하였다. 이와 같은 가상현실(Virtual Reality, $\mathrm{VR})^{57)}$, 증강현실(Augmented Reality, AR)58), 복합현실(Mixed Reality, MR)59)이 추 구하는 바도 결국 미디어의 현실성 몰입 극대화이다. 최근에는 확장현실(eXtended Reality, XR)이란 개념도 등장하였다.60) 또한 '머신러닝'과 '딥러닝'을 통해 소비자의 취향에 맞는 선택을 할 수 있게 되었다. '머신러닝(Machine learning)'이란 알고리즘과 빅데이터를 통해 컴퓨터(기계)를 학습시켜 인공지능을 구현하는 방식이다. '딥러닝(Deep learning)' 은 여러 층으로 깊이 구조화된 인간두뇌 신경망을 본떠 인공신경망을 기본으로 하는 머신러닝의 한 분야를 뜻하며, 컴퓨터(기계)가 스스로 데이터를 분석하여 학습하는 기술로 인공지능이 획기적으로 발전하게 되었다.61) 이러한 기술을 이용해 Netflix는 사용 자의 영화 선호를 매우 정확하게 예측하는 기술을 보여준다. 사용자의 시청습관은 데이터 화 되어 어떤 종류의 영화를 좋아할지 예측해서 추천해준다. 넷플릭스가 사용하는 인공지 능은 사용자들이 시청할수록, 데이터가 쌓이면 쌓일수록 스마트해진다.62)

54) 고삼석. 2019. 「5G 초연결사회, 완전히 새로운 미래가 온다」 메디치, p 25.

55) $\mathrm{HD}$ 해상도에 이은 차세대 영상표준으로 초고해상도의 화질을 칭하는 용어이다. $4 \mathrm{~K}$ 는 영상 단말의 가로 해상도가 대략 4,000 픽셀 정도 되는 해상도라는 의미이며, 디스플레이 시장에서는 가로 3,840 픽셀, 세로 2,160 규격이 통용되고 있다.

56) 고삼석. 2019. 「5G 초연결사회, 완전히 새로운 미래가 온다」 메디치, p. 48

57) 현실의 특정환경이나 상황을 컴퓨터 등을 통해 그대로 모방하여 이용자가 마치 실제로 주변상황이나 환경 과 상호작용하는 것처럼 만드는 컴퓨터 그래픽 기법을 말한다.

58) 가상현실의 한 분야로서 실제 환경에 가상의 사물과 정보를 합성하여 마치 원래 환경에 존재하는 것처럼 보여주는 컴퓨터 그래픽 기법을 말한다.

59) $V R$ 과 $A R$ 을 활용하여 가상과 실제를 결합하는 형식을 말한다.

60) 고삼석. 2019. 「5G 초연결사회, 완전히 새로운 미래가 온다」메디치, p. 49

61) 4차산업혁명 융합법학회. 2020. 「4차 산업혁명의 이해」박영사, p. 36

62) 4차산업혁명 융합법학회. 2020. 「4차 산업혁명의 이해」박영사, p. 34 


\section{제5절 코로나19로 인한 변화}

최근의 국제정치적, 경제적, 기술적, 사회문화적 변화들은 코로나19 상황이전에도 꾸 준히 진행되어 오고 있었다. 코로나 이전에 미중경쟁의 심화, 다자주의 축소와 자국중심 주의 확산, 경제적 양극화, 디지털 경제의 확산, 사회적 불평등, 1 인 가구 증가에 따른 사회 세태의 변화, 4 차 산업혁명 시대로의 진입과 디지털 기술의 발전 등이 꾸준히 진행 되고 있는 상황이었다. 이러한 전 분야의 변화가 코로나19로 인하여 급격하게 변화되거 나 새로운 기술의 접목을 통한 위기 극복 과정에서 매우 빠른 속도로 각 분야의 변화를 추동하고 있다.

\section{가. 국제정치측면의 변화}

코로나 19 로 인한 위기는 단순히 보건, 의료 측면의 위기가 아니라 경제, 사회, 교육, 정치, 외교안보 등 지구촌 전반에 걸쳐 중요한 변화를 가져오고 있다.63) 코로나 19 이 후, 미국과 중국은 협력 대신 기존의 전략적 경쟁을 더욱 가속화 하고 있다. 마중 관계는 무역갈등을 넘어 이데올로기 경쟁으로까지 격화되면서 악화일로를 걷는 중이다. 2018 년부터 시작된 무역전쟁이 무역 충돌을 넘어 화웨이와 $5 \mathrm{G}$, 인공지능, 대만, 홍콩, 남중 국해, 일대일로 등 전방위적으로 충돌하는 모습을 보여주고 있다. 2020년 1월 우한에서 시작된 코로나 19 확산에 코로나 팬데믹의 책임논쟁에서 미-중 모두 상대방에게 책임 떠넘기기 즉, '블레임 게임(Blame game)'에 열중하고 있다.64) 대만독립을 주장하는 차 이잉원 총통 재선, 홍콩 보안법 통과, 휴스턴과 청두 총영사관 폐쇄, 홍콩 특별지위 박탈, 남중국해 대규모 연합훈련 실시 등 강도와 범위를 심화시켜 나가고 있다.65) 미국과 중국

63) 유현석. 2021. 「국제정세의 이해」한울엠플러스, p. 457

64) 김준형. 2020.「코로나 $19 \times$ 미국대선, 그 이후의 세계」 평단, pp. 46-47

65) 정재흥. 2020. “제3장 중국의 세계전략과 미국" 「미·중 패권시대 한국의 대외전략」(이상현 외) 세종연구 소, p. 152 
의 경쟁은 중국의 역내 리더십에 대한 욕심과 미국의 기존 패권 유지를 위한 공세적 방 어가 상승작용을 일으키고 있다.

미국은 중국을 '신뢰할 수 없는 국가'로 부각시키며, 중국의 행태는 공산주의 체제에 서 비롯된 것이라고 주장하면서 미중 갈등을 체제경쟁으로 전환하면서 공세를 더욱 강 화하고 있다. 결과적으로 코로나 사태는 미국에게 중국 견제를 위한 서방세력의 집결을 촉진할 수 있는 좋은 소재로 '반공주의(anti-communism)'를 제공했다고 판단된다.66) 경제적으로는 중국을 배제하고 글로벌 공급망을 새롭게 구축할 전략을 추진하고 있다. 미국은 동맹국, 파트너 국가들에게 타진 중인 '경제번영 네트워크'는 이번 기회에 중국 을 겨냥한 배타적인 경제블록을 구축하고자 하는 미국의 생각이 담겨있다고 보는 시각 이 많다.67) 2020년 5월 미 백악관은 대중국전략보고서를 공개했다. 보고서의 핵심은 향후 미국이 중국에 대해 '경쟁적 접근(competitive approach)'을 하겠다는 점을 분명 히 천명한 것이다.

미중경쟁이 더욱 심화되는 속에서 국제 다자주의의 경우, 코로나 이후 다자주의 축소 경향이 줄면서 여러 방향의 흐름이 혼재되는 양상을 보이고 있다. 미국의 트럼프 대통령 의 퇴임과 바이든 대통령의 등장으로 인하여 새로운 전환의 가능성이 열렸다. 바이든 미국 대통령은 대통령 당선인 시절부터 국제문제에 대한 다자적인 접근법으로 돌아갈 것임을 시사해왔다. 트럼프 행정부가 탈퇴한 파리 기후협약, 이란 핵협정 등에 미국을 복귀시킬 계획이다. 코로나19 에 대해서도 세계와 공동 대응을 추진하겠다고 약속했 다.68) 미국은 코로나 이전부터 추진해온 미국 우선주의를 변화시켜 일부 다자주의 복귀 움직임을 보이고 있는 것이다.

한편, 개발도상국과 후진국을 대상으로 한 보건협력의 필요성이 증대되고 있다. 문재 인 대통령은 2021년 1월 27일 화상으로 세계경제포럼(WEF)이 주최한 '2021 다보스 아젠다 한국정상 특별연설”에 참석하여, 마무리 발언을 통해 “코로나 상황을 겪으면서 안타까웠던 것 중 하나는 세계가 그동안 발전시켜 왔던 연대와 협력, 다자주의 속의 분 업 협력, 인도주의적 상생의 정신, 신뢰와 통합의 정신 등이 사실은 얼마나 취약하고 깨 지기 쉬운 것인가를 확인하게 된 것”이라며 이렇게 밝혔다.69) 미국 정부의 태도변화와

66) 이대우. 2020. “제2장 미국의 세계전략과 중국” 미중 패권시대 한국의 대외전략」(이상현 외) 세종연구 소, pp. 73-74

67) 유현석. 2021. 「국제정세의 이해」 한울엠플러스, p. 460

68) 뉴시스. 2020.12.15. "OECD 총장 "다자주의, 코로나 재건 유일한 길...바이든 기대"” 
코로나 종식을 위한 다자협력의 필요성이 증대되는 속에서 공동의 노력의 필요성이 제 기되고 있다. 하지만, 기존의 다자주의 축소의 움직임이 완전히 사라지지 않았고, 일정 기간 여러 움직임이 혼재된 상황이 지속될 것으로 보인다.

[그림 2-7] 코로나19 이후 EU에 대한 인식변화

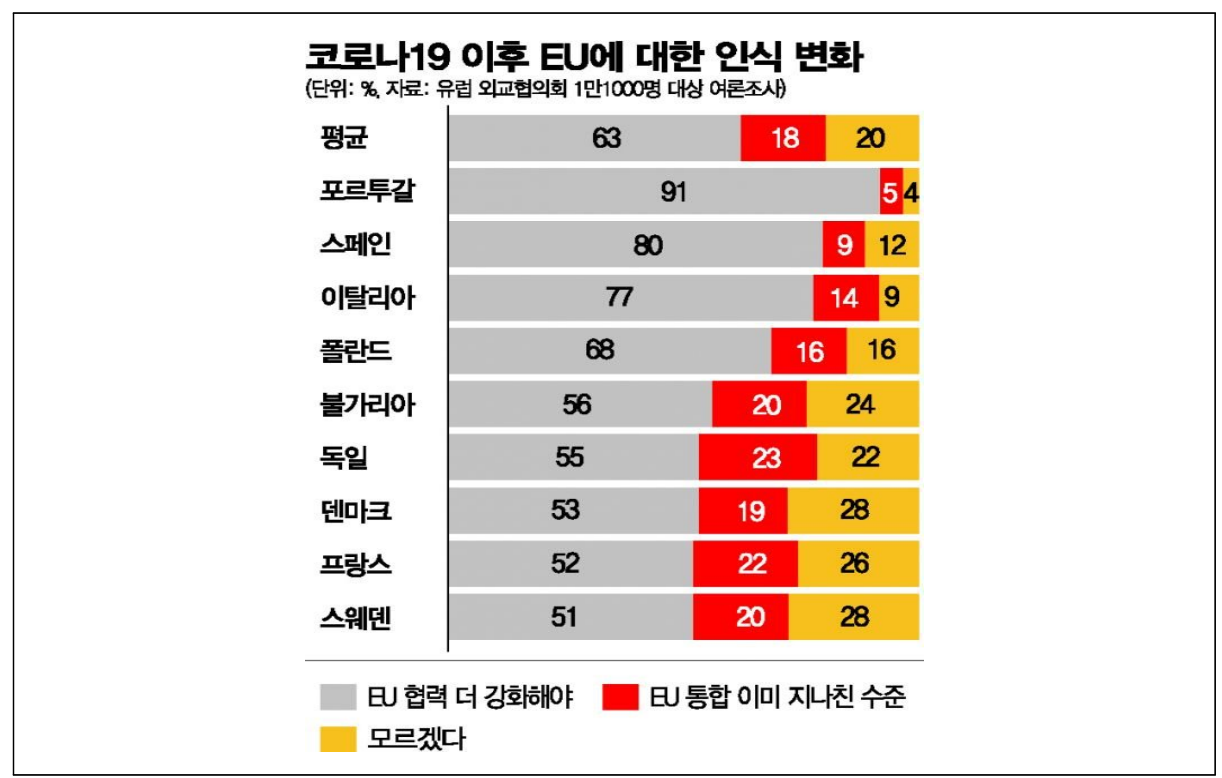

출처: 아시아경제. 2020.07.09. “위기에 강했던 ‘유럽 극우 포퓰리즘'의 코로나19 겪으며 몰락”.

자국 중심주의의 행태도 코로나 19 이후 변화가 생겼다. 코로나 19 가 창궐한 이후 유 럽 내 극우 포퓰리즘(대중영합주의) 정당들이 퇴조하고 있다. 8일(현지시간) 폴리티코 등 에 따르면 독일 극우정당인 '독일을 위한 대안(AfD)' 지지율은 올 초 $14 \%$ 에서 코로나19 사태를 겪으면서 최근엔 $10 \%$ 로 하락했다. 이탈리아에서는 극우 포퓰리즘 정당인 '동맹' 의 지지율이 올해 초 $32 \%$ 에서 최근에는 $26 \%$ 로 하락했다. 그 원인에 대해서는 여러 가 지 설명이 나오고 있다. 우선 이번 위기를 겪으면서 포퓰리즘 정당의 무능이 확인됐다는 점이다. 독일 $\mathrm{AfD}$ 는 코로나19 대응과 관련해 오락가락해 빈축을 샀다. 코로나19 초기 에는 독일 정부가 너무 대응이 늦다고 비판하더니, 나중에는 독일 정부의 대응이 너무 과도하다고 비판하는 행보를 보인 것이다. 이와 함께 전염병 창궐이 정부기관과 관료의

69) 대한민국 정책브리핑. 2021.01.28. "문 대통령 “국제사회 코로나 대응, 연대·협력·다자주의·포용 정신 되살려야" 
중요성을 재확인한 점도 포퓰리즘 정당의 인기를 떨어뜨린 요인으로 꼽힌다. 포퓰리즘 세력은 소외된 시민들의 카타르시스를 자극하기 위해 정부기관을 조롱하는데 주저하지 않았다. 일단 코로나 상황으로 인하여 자국중심주의의 내부적 기반인 포퓰리즘 정치세력 들이 퇴조하는 속에서 여러 가지 봉쇄 조치 등이 지속되고 있어, 자국 중심주의 양상이 어떻게 변화될지 그 추이를 좀 더 지켜봐야하는 상황이 되었다.

\section{나. 경제 측면의 변화}

주요국 경제의 동반 부진과 상품교역이 큰 폭으로 둔화 되었고, 각국의 코로나19 확 산 억제조치(국경봉쇄, 입국제한 등)가 시행 중인 데다 불안 심리도 고조되면서 인적교 류가 크게 위축되었다. 그리고 글로벌 공급망이 훼손되었다. 코로나19 사태가 장기화될 경우 중간재 수급차질에 따른 글로벌 제조업의 피해가 불가피해졌다. ${ }^{70)}$ 코로나19의 확 산 이후 세계경제는 자본의 세계화에 기반하여 경제적 자유주의, 정치적 수단을 통한 시장의 개방과 $\mathrm{GVC}$ 의 한계를 확인하고 있으며, 영국의 브렉시트와 같은 글로벌리즘의 포기와 지역주의, 트럼프의 자국우선주의로 대표되는 탈세계화, 신고립주의 그리고 일자 리 정책에 따른 제조업 리쇼어링으로 국가주의의 추세와 탈세계화가 전염병처럼 확산 및 일반화되고 있다.71)

1980년대 후반 냉전체제의 붕괴와 1990년대 세계화로 다국적 기업과 국제무역협정 을 중심으로 글로벌 생산소비체제가 형성되면서 선진국과 개도국을 불문하고 정치, 경 제, 사회, 문화 등 거의 모든 영역에서 글로벌 연계가 가속화되었다. 단순 제조업만이 아니라 스마트폰, 바이오 신약 등 복잡한 공정의 제품 역시 글로벌 분업구조로 생산·유 통·소비되어 왔다.72) 코로나19의 경제적 충격은 바로 이 글로벌 분업구조를 붕괴시키고 있다. 비록 2008년 금융위기 이후 글로벌 가치사슬 성장이 정체되기 시작했지만, 이번 처럼 한순간에 공장이 멈춰 서고 소비 역시 급격히 증발하면서 경제가 마비되는 상황은 일찍이 경험하지 못했다.

70) 한국은행. 2020.04.12. “코로나19 글로벌 확산이 세계 경제에 미치는 영향." (국제경제리뷰, 제2020-9호).

71) 김학민. 2020. "제4장 4차 산업혁명, 지역경제 업그레이드, 글로벌 가치사슬"「미래의 귀환」(김소영 외) 한울아카데미, p. 73

72) Rivoli, P. 2014. The travels of a t-shirt in the global economy: An economist examines the markets, power, and politics of world trade. New preface and epilogue with updates on economic issues and main characters. John Wiley \&Sons. 
코로나19는 글로벌 공급 체인이 가장 효율적인 생산 메커니즘인 동시에 가장 취약한 메커니즘이라는 것이 드러냈다. 글로벌 공급 체인은 외부적 위기 요인으로 인해 공급 충격이 발생할 경우, 세계 경제가 마비될 수 있는 위험성을 내포하고 있다는 것이 명확 해진 것이다. 실제로 중국에서 코로나로 인하여 전국적으로 경제활동이 일시적으로 정지 되면서 아주 다양한 제품의 글로벌 가치사슬이 일시적으로 마비되었다. 포춘지 선정 1000 대 기업 가운데 938개 기업이 코로나19 사태로 영향을 받은 것으로 조사되었는데 그 가운데 다수는 중국에서 중간재와 최종재를 공급받거나 생산하는 곳이었다. 코로나 이후 중국에 지나치게 의존해왔던 기존 관행에 변화가 발생한 것이다. 다각화와 본국 회귀는 코로나 19 이전부터 진행되고 있었다. 중국에서 임금이 올라가고 지대를 비롯한 각종 비용이 상승하면서 중국보다 더 싼 곳을 찾거나 아예 본국으로 생산기지를 다시 옮기려는 움직임이 없지 않았다. 코로나 19사태로 이러한 경향이 더욱 가속화되었다. ${ }^{73)}$

또한, 전례 없는 질병의 확산이 탈세계화 현상을 더욱더 부추겨 비관세장벽까지 쌓아 올리고 있다. 이 상황은 탈세계화 현상이 더욱 빠르게 확산하는 계기가 되었다. 한국무 역협회에 따르면, 2020년 들어와서 한국 수입규제 신규조사개시 건수가 전년 대비 2020년 상반기에만 총 8건이 증가했다. 그 이유로, 코로나 19로 인한 주요국의 자국 기업 지원정책 등 향후 상계관세 리스크 증가와 주요 규제국의 중국산 우회 덤핑 방지 조치 정책으로 인한 수입규제 대상국 확대를 들 수 있다. 미국은 2020년 상반기 총 14 개 품목 관련 30개국에 대해 신규 조사 72 건을 개시했으며, 뒤를 이어 인도 또한 2020 년 상반기 총 18 개 품목 관련 21 개국에 대해 신규조사 54 건을 개시했고, 중국 12 건, 인도네시아와 한국 각각 4 건 순으로 나타났다. 현재 한국에 대해 수입규제는 총 219건 으로, 반덤핑 관세가 총 164 건으로 가장 많았고, 세이프가드 조치는 총 46건으로 그 뒤 를 이었다. 한국 수입규제 신규조사는 미국과 인도가 가장 많았으며, 터키와 호주도 한 국에 대해 각각 1 건의 수입규제 신규조사를 개시했다. 미국과 인도의 수입규제는 지속적 으로 증가할 전망이며 아세안 국가의 조치도 증가하는 추세이다. 일부 아시아 국가 및 아프리카 등 개발도상국의 세이프 가드 조치도 지속적으로 발생하고 있으며, 현지 생산 자 외 글로벌 기업의 제소도 발생하여 일부 전략적 활동도 확인되고 있다. ${ }^{74)}$

73) 김대륜. 2020. “제5장 코로나19 사태와 글로벌 가치사슬”「미래의 귀환」(김소영 외) 한울아카데미, p. 83

74) 김학민. 2020. “제4장 4차 산업혁명, 지역경제 업그레이드, 글로벌 가치사슬"「미래의 귀환」(김소영 외) 한울아카데미, pp. 71-72 
다른 나라들도 자국 내 생산기지를 구축하고 해외로 나간 자국 기업들을 불러들이기 위해 법인세 인하와 같은 방안을 경쟁적으로 시행하고 있다. 이러한 움직임은 전 세계의 단일시장화와 정반대인 보호무역주의를 강화할 가능성도 있다. 이처럼 글로벌화가 급격 히 감소하거나 역전될 가능성이 크다. 75 ) 경기절벽(economic cliff)으로 추락하면서 기 업이나 개인의 생존권이 위협받고 있다. 한계가구나 한계기업이 늘어나고 실업과 폐업이 줄을 잇고 있다. 한국은행은 기준금리를 $0 \%$ 대로 인하했고, 금융기관들의 대출은 확대되 었다. 정부는 연이은 추경을 통해서 재정지출을 최대한 확대하고 있다. 사회 전반적으로 양극화가 확산되는 가운데 지속가능발전 측면에서 최근 가장 악화되고 있는 것은 주택 자산의 양극화이다. 2013년 이후 계속된 주택 공급부족과 최근 풍부해진 유동성으로 인 해 서울의 주택시장이 걷잡을 수 없을 만큼 극단적인 양극화로 치닫고 있다. 한국에서는 주택 등 부동산 자산이 전체 자산 중에서 차지하는 비율이 $80 \%$ 내외로 높아서 주택자산 의 양극화는 바로 자산의 양극화이다. 자산의 양극화를 노동 소득으로 만회하기 힘들어 졌다. 서울시의 아파트 중위 가격이 약 10 억원인데 비해, 서울시 중위 가구의 연소득은 약 6,000만원이다.76) 팬데믹 종식 후 세계 각국 및 지역 정부와 중앙은행이 거의 동시 에 금융완화에서 금융긴축으로 180 도 정책적 변화를 기할 가능성이 있으며, 이는 세계 경제에 다시금 타격을 줄 수 있다. 77 ) 각 국마다 차이가 있겠지만, 팬데믹 종식 후에 각 국 및 지역 정부에 가해지는 재정재건에 대한 압력이, 만연기가 길어질수록 커지기 쉬우 며 정부도 팬데믹 종식 후에 그러한 흐름에 따라 증세와 세출삭감 등을 급속도로 대담하 게 추진할 위험성이 높아질 것이다. ${ }^{78)}$

\section{다. 사회문화적 측면의 변화}

코로나 이전에 한국사회는 사회적 불평등이 확산되고, 세대갈등이 심화되는 상황이었 다. 또한, 주거 세태의 변화 속에서 개인주의의 확산 등과 연관되어 1 인 가구가 확연히 증가하는 사회적 흐름을 보이고 있었다. 이는 곧 초개인화 현상의 증가를 의미한다. 시 민들이 초개인화 형태로 사회생활과 개인의 생활을 꾸려나갈 수 있는 것은 디지털 기술

75) 유현석. 2021. 「국제정세의 이해」 한울엠플러스, p. 461

76) 이영환 외 2020.「포스트코로나 대한민구: 집단지성 27 인의 성찰과 전망」한울엠플러스, p. 22

77) 노무라종합연구소. 2020.「코로나 대전환」(주)알에이치코리아, p. 53

78) 노무라종합연구소. 2020.「코로나 대전환」(주)알에이치코리아, p. 67 
의 발달로 인하여 과거에 다른 사람들과 소통을 하면서 풀 수 있었던 여러 가지 문제들 이 기술의 발달과 디지털 플랫폼의 발달로 인하여 대체 가능한 수단들이 등장하면서 해 결되게 되었다. 하지만 이러한 변화들 속에서도 코로나로 인한 여러 가지 사회생활의 문제와 심리적·정서적 어려움은 배가되어 사회문제화 되고 있다.

사회적 불평등문제는 더욱 심화 되었다. 코로나19로 인하여 사회 내의 계층 간 격차 가 더욱 심화되고, 고용 구조의 약화로 인하여 빈곤 가능성이 증가하고 있다. 요식업 등 서비스업 분야의 코로나 19 방역문제로 인한 매출 감소와 영업정지로 인하여 많은 이들 이 일자리를 잃거나 좀 더 불안정한 직업군으로 이직을 하였다. 이러한 변화 속에서 사 회적 불평등 문제는 더욱 심화 되었다. 서울연구원이 최근 발표한 '서울시 사회갈등 이 슈 진단과 정책 시사점' 보고서를 보면 만 19세 이상 서울시민 10명 중 8명은 코로나19 이전보다 사회의 갈등이 더 심각하다고 인식하고 있는 것으로 나타났다.79) 저소득층은 사회적 거리두기와 봉쇄정책으로 인해 다른 계층보다 더 많은 일자리를 잃었다. 영국의 경우, 엔터테인먼트와 레크리에이션, 숙박, 요식업이 3대 최저임금 산업에 속한다. 그리 고 코로나 19 위기 동안 폐쇄되거나 거래가 중단된 기업의 $80 \%$ 이상이 이 산업분야에서 발생하였다. 그로 인해 해당 업종에서 많은 직원들이 실직하거나 일시해고 되었다.80) 국제구호개발기구 옥스팜(Oxfam)은 25 29일 온라인으로 열리는 세계경제포럼 (WEF) '다보스 아젠다(The Davos Agenda)' 주간에 맞춰 발표한 '불평등 바이러스 (The Inequality Virus)' 보고서를 통해 지구상에서 가장 부유한 1,000명이 불과 9개 월 만에 코로나 바이러스(COVID-19)로 인한 경제적 손실을 회복한 데 반해, 세계 최빈 곤층은 10 년 이상 걸릴 수 있는 것이라고 밝혔다.81) 이 같은 불평등 심화의 흐름 속에서 젊은 층들은 안정적 일자리를 더욱 찾기 힘들게 되고, 그로 인해 세대갈등도 더욱 심화 되거나 심각한 갈등 상황에 직면하게 될 수 있다. 코로나 사태 초기, 활동 반경이 넓은 20,30 대가 치명률이 높은 중장년층에게 코로나 바이러스를 옮긴다는 우려가 있었고, 그 이태원 클럽을 중심으로 한 코로나19 확산 등으로 인하여 젊은 층에 대한 비난이 거 세어졌었다. 그리고 중장년층 남성들이 방역 지침을 어기는 사건들이 여러 차례 알려지

79) 서울연구원. 2021. "서울시 사회갈등 이슈 진단과 정책시사점." 서울연구원.

80) 아나스타샤 페트라키(Anastasia Petraki). 2020.06.11. "코로나 19 로 인해 조명된 사회적 불평등 은 어떤 의미인가?"Schroders.

81) 옥스팜. 2021.01.25. ““코로나 불평등 심화, 바이러스만큼 치명적” 억만장자 9개월 만에 코로나19 손실 회복, 극빈층은 10 년 이상 걸릴 수도“ 보도자료. 
면서 이에 따른 중장년층 남성에 대한 혐오와 비난도 거세어졌다. 각 세대 간 서로 비난 의 대상으로 삼으며 세대갈등이 확산되는 양상을 보이고 있다.

코로나 19 로 인한 불평등의 증가와 일자리의 감소와 실직, 세대 간의 상호 비난은 사 회전반에 심리적 어려움이 퍼져있는 하나의 사회적 재난으로 인식 될 수도 있다. 코로나 19 는 자연재난과 사회재난의 성격을 동시에 갖는 복합재난으로, 발생 원인이나 피해 규 모를 예측하기 어려운 불확실한 현대의 재난이라고 볼 수 있다. 재난 상황에 처한 사람 들은 심리·정서적으로 곤란을 겪으며, 재난 이후에도 변화된 환경과 재정적 손실, 가족 관계의 변화 등이 장기적인 생활 스트레스로 작용하여 2차 트라우마의 요인이 되기도 한다(Norris, Friedman, \& Watson 2002)82), 이에 재난 이후 사람들은 급성 스트레 스 장애(Acute Stress Disorder, ASD), 외상후 스트레스 장애(Post Traumatic Stress Disorder, PTSD)를 경험하거나 우울증, 자살 등의 정신건강 문제를 경험할 수 있다. 코로나 19 와 같은 신종 바이러스 출현은 예측 가능성이 낮고 감염 가능성은 가시적이지 않으므로 감염 지역 내 주민들은 만성적인 불확실성을 경험함으로써 불안 증상 등의 심 리적 장애를 가질 수 있다. 또한, 코로나 19는 개인의 심리적 피해를 비롯해 긴장, 두려 움, 유언비어를 확산시켜 사회적 불안 및 구성원들 간의 다양한 심리적 갈등이나 집단 트라우마를 유발하기도 한다.83)

2020년 3월 한국트라우마스트레스학회(Korean Society for Traumatic Stress Studies, KSTSS)에서는 국민 1,014여 명을 대상으로 정신건강 실태조사를 실시했다. 그 결과, 연구 참여자 중 상당수가 코로나19로 인한 걱정과 두려움을 경험했는데, 코로 나19로 인해 가족이 감염되는 것에 대한 걱정과 두려움을 일주일 이상 경험한 응답자 비율이 $76.8 \%$ 로 가장 많았다. 이어 자신의 감염이 타인에게 전염되는 것(75.52\%), 자신 의 감염으로 인해 타인에게 피해를 주는 것(72.45\%)에 대한 걱정과 두려움을 다수가 느 끼는 것으로 나타났다.84) 이러한 사회적 갈등의 확산 분위기 속에서 사람들은 여러 가지

82) Norris, F. H., Friedman, M. J., \& Watson, P. J. 2002. “60,000 disaster victims speak: Part II. Summary and implications of the disaster mental health research." Psychiatry: Interpersonal and biological processes, Vol.65m No.3, pp.240-260.

83) 허연주 \& 이민규. 2017. "사회적 재난으로 인한 간접외상 척도의 개발과 타당화 연구." 「한국심리학회지: 문화 및 사회문제」, Vol.23, No.3, pp. 381-407; Knudsen, H. K., Roman, P. M., Ducharme, L. J., \& Johnson, J. A. 2005. "Organizational predictors of pharmacological innovation adoption: The case of disulfiram.” Journal of Drug Issues, Vol. 35, No. 3, pp. 559-573.; 장은 진. 2020. “10장. 코로나 19 와 심리방역”「포스트코로나 대한민국: 집단지성 27인의 성찰과 전망」(이영 환 외) 한울엠플러스, p. 156 
형태로 정신적 스트레스를 해소하기 위한 활동들을 찾게 된다. 코로나로 인하여 기존의 타인과의 접촉방식과는 다른 방식을 추구할 수 밖에 없다. 따라서 문화적 삶은 포스트 코로나 시대에 효율적인 만족감의 핵심이다. 코로나 팬데믹으로 인해 또 다른 종류의 행복개념이 중요해질 것으로 예상된다. 지금까지 사람들은 다른 사람의 인정을 받기 위 해 치열한 삶을 살아왔다고 해도 과언이 아니다. 문화적 삶은 앞으로 훨씬 더 중요해질 것이다. 작고 소박하더라도 내가 직접 하는 문화적 행위로 확대될 것이다.85) 그런가 하 면 코로나 19 의 확산이 다소 약화 되는 시기에는 억눌린 소비심리로 인해 럭셔리·기호상 품 및 비필수재로의 소비 양극화 양상도 동시에 나타나고 있다. 불안감에 대한 보상심리 가 작용하는 것이다. ${ }^{86)}$

개인의 선호도는 디지털 기술과 만나 더욱 명확하게 드러난다. 넷플릭스나 스포티파 이 같은 콘텐츠 플랫폼은 $\mathrm{AI}$ 를 기반으로 하고 있다. $\mathrm{AI}$ 는 문제를 해결하고, 패턴을 식별 하고, 다음에 무엇을 해야 하며, 혹은 심지어 미래의 결과가 어떨지 예측하기 위해 일련 의 데이터에 알고리즘을 적용하는 것을 뜻한다. 87 ) 콘텐츠 플랫폼 기업들은 $\mathrm{AI}$ 를 이용해 사용자들이 무엇을 보고 듣기를 원하는지 파악해 맞춤형 추천을 하고, 넷플릭스의 경우, 새로운 콘텐츠를 제작하기도 한다. 중국의 검색엔진 소우거우는 저자의 목소리를 모방해 소설을 읽어주는 $\mathrm{AI}$ 를 개발 중이라고 밝혔다. 딥페이크(딥러닝과 페이크의 합성어로 인 공지능의 영상합성, 조작기술)가 세간의 주목을 받는 사람들의 음성과 영상콘텐츠를 만 들어내는 것과 유사한 방식이다. 이는 오디오북 시장에 혁신을 일으킬 수 있다. 소니는 곡에 따라 드럼소리를 만들 수 있는 $\mathrm{AI}$ 를 개발했다.88)

또, 가상현실을 구성하는 기술 역시 발달하였다. 소니는 가상현실 콘텐츠 구현을 위해 ‘볼륨메트릭 리얼 월드 캡처’와 ‘360 리얼리티 오디오 뮤직 프로덕션 툴' ‘입체(3D)제작 을 활용한 리얼리티 콘서트' 등 새로운 기술이 이번 2021년 CES에서 소개하였다. '소니 이노베이션 스튜디오'의 '아톰 뷰' 소프트웨어는 디지털로 전환한 실제 공간 정보를 실 시간으로 VR 상에 재현하는 걸 돕는다. 360도 음향 효과를 만들어내는 '360 리얼리티

84) 장은진. 2020. “10장. 코로나 19와 심리방역"「포스트코로나 대한민국: 집단지성 27인의 성찰과 전망」 (이영환 외) 한울엠플러스, p. 157

85) 김경일. 2020. “제12장 포스토로나 시대의 심리적 방향성”「미래의 귀환」(김소영 외) 한울아카데미, pp. 159-161

86) 노무라종합연구소. 2020.「코로나 대전환」(주)알에이치코리아, p. 130

87) 버나드 마. 2020. 「다가온 미래」다산북스, p. 20

88) 버나드 마. 2020. 「다가온 미래」다산북스, p. 25 
오디오' 기술은 VR 기기를 사용할 때 제공하는 소리에 공간감을 더한다. 소니는 두 기술 을 조합해 고품질의 VR 콘서트 콘텐츠를 제작하고 있다.89) 코로나 초기에는 취소와 지 연으로 공연 자체가 힘들었으나 장기화 국면에서는 '직접 관람'한다는 명제를 깼다. 유 명 뮤지컬을 유튜브 채널에 공개하거나 '레이디 가가(Lady Gaga)'와 같은 세계적인 가 수가 동료 가수들과 함께 온라인 자선 콘서트를 각자의 공간에서 참여하는 방식으로 기 금을 모으기도 하였다.90) 서울시향도 온라인 콘서트나 VR 오케스트라 영상을 유튜브로 올리고 있다.

오프라인 공간들도 기술을 접목시키며 새롭게 재구성되었다. 뉴욕타임즈 기자 데이비드 포그(David Pogue)는 주말 동안 7개의 에어비앤비의 온라인 체험 코스(Online Experience Course)를 신청해 참여했다.91) 기자는 약 200개 정도 개설된 온라인 체험코 스 중에서 시간대가 적합한 코스들을 선정해 미리 신청하고 주말 이틀 동안 계속 참여했다. 이러한 코스들은 대략 1 시간 정도 진행되며 정해진 시간, 예를 들어 7 월 18 일 토요일 오후 2시에 시작해 3시에 끝난다는 코스 진행 시간, 코스 참여 인원 정보(최소 2명에서 최대 10명), 참가비 정보 등을 사전에 제공한다. 가격대는 다양하다. 신청이 완료되면 정해진 시간에 줌을 이용해 온라인 체험 코스를 준비한 호스트와 온라인상에서 만난다.92)

〈표 2-7〉 에어비앤비 온라인체험코스

\begin{tabular}{c|c}
\hline 온라인 체험 코스 이름 & 호스트국가 \\
\hline K팝 스타처럼 춤추기 & 한국 \\
\hline 모로코 가족들과 함께 요리를 & 모로코 \\
\hline 상어연구가의 하루일상 & 남아프리카 공화국 \\
\hline 도쿄의 애니메이션과 서브컬쳐 & 일본 \\
\hline 런던 차이나타운에서의 문화여행 & 영국 \\
\hline 개인의 점성술 및 출생 천궁도 읽기 & 스페인 \\
\hline 체르노빌의 개들과 만나기 & 우크라이나 \\
\hline
\end{tabular}

89) 한국경제신문 CES 2021 특별취재팀. 2021. 「CES 2021」한국경제신문, p. 76

90) 양혜원·김면·차민경·김현경·노수경. 2020.「코로나 19 가 문화예술분야에 미친 영향 및 정책대응방안 연 구」 한국문화관광연구원, pp. 39-40

91) New York Times. 2020. 5. 4. “I spent a weekend bingeing Airbnb's virtual experiences. Was it worth it?"

92) 김동현·마정산. 2020. 「비대면 비즈니스트렌드」정보문화사, pp. 141-143 
모든 활동이 쌍방향으로 진행된다. 미리 녹화한 내용을 보여주는 유튜브와 달리, 에어 비앤비를 통해 호스들이 제공하는 코스들은 실시간으로 진행되며 참여자들은 서로의 얼 굴을 볼 수 있다.93) 미국 및 유럽의 박물관들과 미술관들도 코로나 팬데믹 기간 동안 관광객을 유치하기 위해 박물관 또는 미술관을 가상박물관(Virtual Museum)으로 재탄 생시켰다. 가상박물관은 가상현실 기술을 활용해 박물관 또는 미술관이 아닌 장소에서도 해당 박물관의 유물과 전시품들을 간접적으로 체험하는 활동이다. 유네스코는 2020년 5 월 유럽 내 박물관 중에서 해저유물과 관련된 가상박물관을 운영하는 유럽 내 박물관들 을 적극 홍보하기도 했다.94) 프랑스 루브르 박물관의 작년 누적 방문자 수는 2020년 5월에 이미 2019년 전체 관람객 수인 1400만 명을 넘어섰다. 루브르 박물관은 코로나 19 여파로 2020년 3월 폐쇄됐다가 7월에 다시 열었다. 코로나 19 확산으로 문을 닫은 루브르 박물관은 예술작품을 바로 앞에서 보는 것처럼 생생하게 체험할 수 있는 가상현 실(VR) 투어 프로그램을 홈페이지에 선보였다. 3월 12일부터 5월 22일까지 70 여 일 동안 루브르 박물관 홈페이지를 방문한 사람만 1510만 명에 달했다.95) 이처럼 코로나 19 상황 하에서 여러 가지 사회문제가 발생하는 속에서 문화분야는 발달된 디지털 기술 을 활용하여 새로운 시도들을 하면서 수요자 층에 맞춤의 새로운 문화상품을 개발하면 서 사회문화적 변화를 추동하고 있다.

\section{라. 기술측면의 변화}

코로나19가 초래한 글로벌 환경변화를 살펴보면 ‘비대면 사회로의 전환, ‘바이오헬스 시장의 도전과 기회' '위험대응 일상화', '자국 중심주의 강화' 등으로 요약할 수 있다. 그 중에서도 '비대면 사회로의 전환’ 우리 사회에 가장 중요하게 영향을 미치고 있는 환경 변화로, 코로나19로 인해 대면접촉을 하지 않는 제품과 서비스가 일상화되면서 디지털 화는 더욱 가속화되고 있다.

4차 산업혁명은 코로나19가 발생하기 이전에는 제조업을 제외한 다른 영역에서는 뚜 렷한 변화를 이끌어내지 못했었다. 하지만 코로나 19 가 초래한 위기대응과정에서 비대면

93) 김동현·마정산. 2020. 「비대면 비즈니스트렌드」 정보문화사, p. 144

94) UNESCO. 2020. 5. 18. "Virtual Museum on underwater cultural heritage respond to the Covid-19 crisis"

95) 한국경제신문 CES 2021 특별취재팀. 2021. 「CES 2021」한국경제신문, p. 74 
접촉을 통한 사회경제적 활동이 늘어나면서 4차 산업혁명이 제조업이라는 한정된 울타리 를 벗어나 헬스케어, 교육, 문화 등 모든 영역으로 확대되고 있다. 집에서 각종 온라인 회의, 교육, 오락, 공연 등이 가능하기 위해서는 네트워크 통신망이 중요하다. 그리고 '눈 앞에서 보는 것처럼'을 더욱 추구하게 되어 $\mathrm{VR}, \mathrm{AR}, \mathrm{MR}$ 과 같은 기술발전도 앞당기게 되었다. 과학기술정보통신부와 한국과학기술기획평가원은 코로나 이후를 준비하는 유망 기술로 $\mathrm{AI}$ 기반의 실시간 질병진단, 실시간 생체정보 측정 및 분석, 감염경로 예측, RNA 바이러스 대항 백신기술, 자율주행차, 배송로봇, 증강기술 등 의학기술도 빠른 발전을 할 것으로 보았다.96) 헬스케어 영역에서는 코로나19를 헤쳐나오는 과정에서 의료의 디지 털화가 가속화되고 있으며, 이를 보여주는 다양한 사례가 보고되고 있다. 교육영역에서는 온라인 교육의 콘텐츠의 질 보장에 대한 요구가 증가하고, 학습데이터와 인공지능 분석을 통한 개별화된 맞춤형 교육의 필요성이 증가하면서 국내 에듀테크 업체들의 기술개발 및 해외 진출도 활발해지고 있다. 2022년부터 공교육에 학습자 개인 맞춤형 학습 서비스 를 제공할 예정이다. 사회적 격리로 대면 및 현장교육이 축소됨에 따라 가상현실과 증강 현실 기술을 활용한 실감형 교육 콘텐츠 개발에 대한 관심도 증대하고 있다.

문화영역에서는 사회적 거리두기로 인해 스포츠, 공연 활동들의 문화산업이 타격을 받고 있다. 오프라인 문화산업의 타격을 해소하기 위해 시청자가 스포츠, e스포츠, 공연 활동 등을 온라인에서도 현실감 있게 실시간으로 체험할 수 있도록 VR방송, 3D TV 등 의 기술을 활용한 실감 중계서비스 시장이 확대되는 추세이다.97)

또 $5 \mathrm{G}$ 네트워크 등 정보통신기술과 이를 활용한 비대면 산업이 더욱 활기를 띨 전망이 다.98) 온라인 쇼핑을 비롯해 원격의료·금융 등도 뉴노멀로 산업개편을 이끌고 있고, 소비 는 인터넷·모바일 쇼핑으로의 이동이 가속화되는 추세이다.99) 아미존은 20만 명을 추가 고용했고, 실시간 스트리밍 업체 넷플릭스는 2020년 1·4분기에 신규가입자 1,580만 명을 추가했다. 아마존, 넷플릭스, 마이크로소프트 3개사의 시가총액은 나스닥 전체 기준으로는

96) 양혜원·김면·차민경·김현경·노수경. 2020.「코로나 19가 문화예술분야에 미친 영향 및 정책대응방안 연 구」 한국문화관광연구원, p. 32

97) 임현. 2020. “제17장 4차 산업혁명 기술 발전 및 시장 수요 전망”「미래의 귀환」(김소영 외) 한울아카데 미, pp. 209-211

98) 문형남. 2020. "21장. 언택트혁명: 사회적 거리두기 기술(SDT) 유망” 포스트코로나 대한민국: 집단지성 27인의 성찰과 전망」(이영환 외) 한울엠플러스, p. 311

99) 문형남. 2020. “21장. 언택트혁명: 사회적 거리두기 기술(SDT) 유망”「포스트코로나 대한민국: 집단지성 27인의 성찰과 전망」(이영환 외) 한울엠플러스, p. 309 
16.3\%(2019년말)에서 20.4\%(2020년 4월)로 늘었다. 언택트 카페(무인카페)가 국내에 등장했다. 로봇 바리스타가 커피를 만들고, 배달 로봇이 서빙을 한다. 휴대폰 매장에도 언택트가 도입되었다. SK텔레콤이 재택근무, 거점 오피스 도입에 이어 비대면 무인 매장까 지 선보인다. SK텔레콤은 휴대폰 개통 및 체험이 가능한 비대면 무인매장을 연내 오픈할 계획이다.100) 코로나로 인한 사회적 거리 두기는 기존의 시공간과의 단절이었다. 사회적 거리(Distance)두기로 인해 사람들이 거주지(Dwelling)에서 지내면서 디지털(Digital) 서비스로 사회적, 경제적 활동을 이어갔다. 또한 극심한 경기침체와 폐업과 실업 등으로 인해 빈익빈 부익부 격차(Differential)는 더욱 심화되었다. 101) 여기에 코로나로 인하여 이전부터 진행되어온 디지털 변환(digital transformation)이 급속히 진행되었다.

디지털 변환의 본격적인 큰 흐름은 ‘차 산업혁명’이 대두되면서부터이다. 2010년 이 후 인공지능, 빅데이터, 블록체인, 사물인터넷 등의 기술이 급속도로 개발되면서 그 이 전과는 다른 세계가 펼쳐지고 있다. 코로나 팬데믹은 4차 산업혁명의 가속페달이다. ${ }^{102)}$ 인더스트리 4.0으로 대표되는 제조 지능화와 함께 인공지능, 빅데이터, 블록체인, 사물 인터넷, 자율주행 등 4차 산업혁명 총아 기술에 기반한 혁신적 서비스의 발전은 코로나 19 이전부터 전반의 디지털 전환을 추동하고 있었지만, 코로나19로 인한 비대면 소비의 폭발적 확산으로 제2의 알파고 충격을 만들어내고 있다.103) 코로나 이후 복귀할 일상은 우리가 개인, 사회, 국가로서 익숙한 과거가 아니라는 것이 점점 분명해지고 있다.104)

\section{마. 환경변화와 국제문화교류}

지금까지 검토한 코로나 19 이후의 국제정치, 경제, 사회문화, 기술 환경의 변화를 정리하면 다음과 같다. 국제정치적으로는 코로나 이전부터 심각해지던 마.중간의 경쟁 코로나 이후 더욱 심화되었다. 미국의 중국견제 기조는 바이든 행정부가 들어선 이후에 도 지속되어 향후 지속적인 갈등이 예상된다. 다음으로, 국제적으로 다자주의 축소와 자 국중심주의 확산의 경향은 코로나 이후 현상적으로는 감소되는 등 다자주의와 자국중심

100) 문형남. 2020. “21장. 언택트혁명: 사회적 거리두기 기술(SDT) 유망”「포스트코로나 대한민국: 집단지 성 27인의 성찰과 전망」(이영환 외) 한울엠플러스, p. 310

101) 이영환 외. 2020. 포스트코로나 대한민구: 집단지성 27인의 성찰과 전망」 한울엠플러스, pp. 17-18

102) 이영환 외. 2020. 포스트코로나 대한민구: 집단지성 27 인의 성찰과 전망」한울엠플러스, p. 21

103) 김소영 외. 2020.「미래의 귀환: 코로나 19와 4차 산업혁명 대전환」한울아카데미, p. 13

104) 김소영 외. 2020.「미래의 귀환: 코로나 19와 4차 산업혁명 대전환」한울아카데미, p. 14 
주의 경향이 여러 방향으로 혼재되어 나타나고 있다.

경제적으로는 코로나 이전부터 전 세계적으로 경제적 양극화가 심화되고 구조적 경기 침체가 지속되고 있다. 그리고 기술적으로 디지털 기술의 발전과 보급이 지속되었다. 단 순히 소비의 효용을 증가시키는 차원을 넘어 개인과 기업의 경제활동, 나아가 정치, 사 회, 문화의 양식에 근본적인 변화의 동인을 제공하게 된다. 코로나 이후 주요국 경제의 동반부진과 상품교역의 둔화, 각국의 코로나19 확산 억제조치(국경봉쇄, 입국제한 등)로 인한 인적교류 위축으로 인하여 전혀 새로운 경제적 상황이 직면하게 된다. 이 상황에서 제조업 리쇼어링과 국가주의의 확산, 탈세계화의 흐름도 감지된다.

[그림 2-8] 코로나19 전후 환경변화와 국제문화교류 변화요인

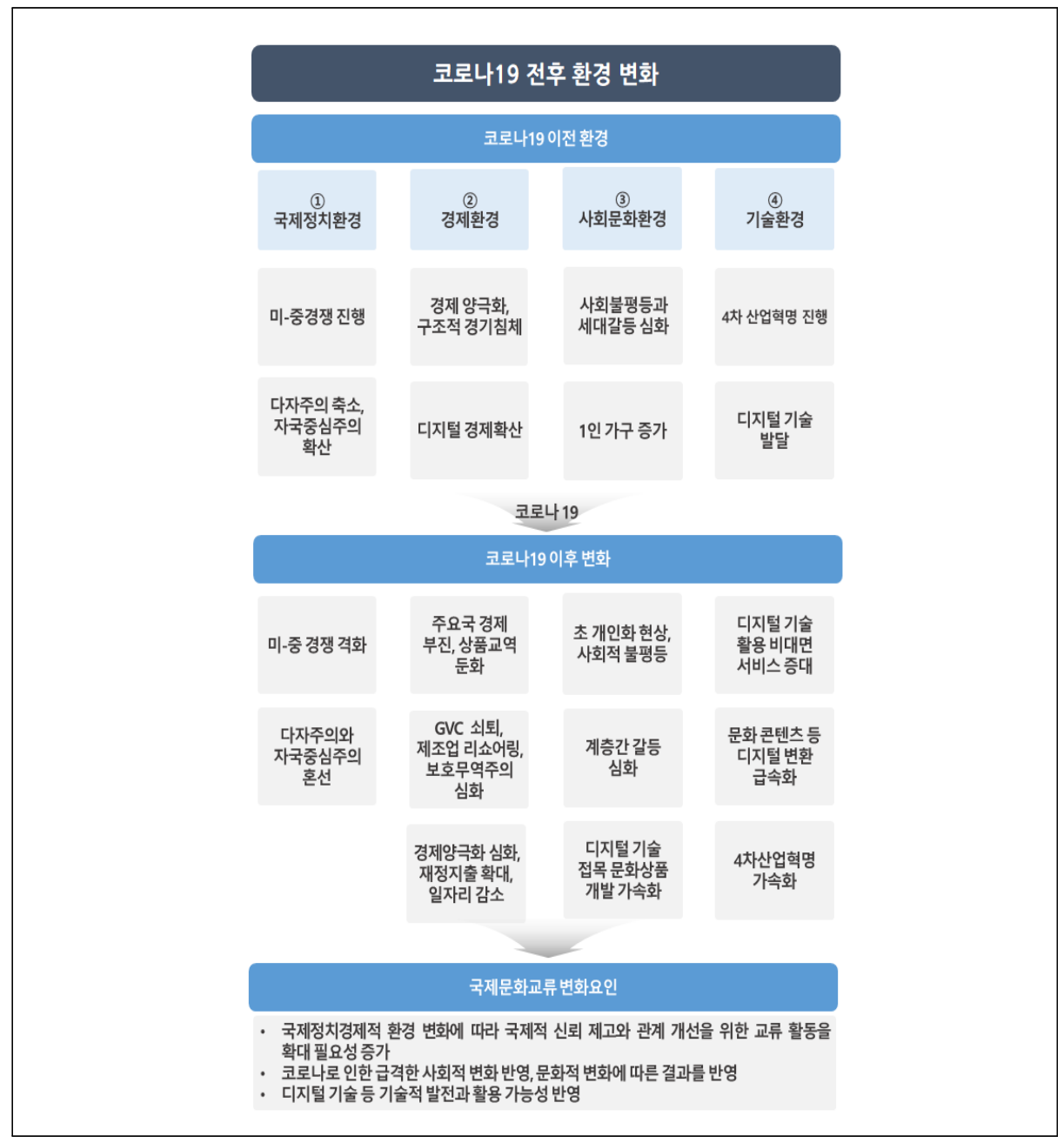


사회문화적으로는 불평등이 심화되는 속에서 1 인가구의 증가로 대표되는 사회구성계 층의 생활과 여가생활 패턴의 변화가 목격되어왔다. 사회적 격차와 사회적 분리가 진행 되는 속에서 코로나가 찾아왔고, 코로나 이후 사회적 거리두기 등으로 인하여 세대뿐만 아니라 개인별 고립과 개인 생활패턴의 변화가 촉진되었다. 코로나 19 로 인하여 디지털 기술을 활용한 여러 가지 사회문화적 변화가 촉진되는 속에서 다양한 새로운 사회현상 도 등장하는 등 사회문화적 현상의 변화가 분명하다.

기술적으로는 코로나로 인하여 로봇(Robot), 인공지능(Artificial Intelligence), 사 물인터넷(Internet of Things, IOT) 등 4차 산업혁명의 주요 기술적 발전이 더 빠른 속도로 촉진되고, 사회적 적용이 더욱 가속화되었다. 사회적 거리두기와 방역을 위하여 여러 발전된 기술이 활용되어 실생활에서의 편리를 가져왔다. 디지털 기술을 기반으로 비대면 접촉의 기회가 확대되어 방역 지침을 수행하면서도 여러 가지 사회활동과 업무 활동을 할 수 있게 되었다.

이러한 국제정치적, 경제적, 사회문화적, 기술적 환경 변화로 인하여 국제문화교류 분 야 또한 여러 가지 변화의 가능성이 열리게 되었다. 국제적 환경의 변화 속에서 새로운 외교정책 방향을 정립하기 힘든 상황이 되었다. 코로나가 언제 종식될지 모르는 상황에 서 한국은 주변 강대국 간의 경쟁 구도 속에 언제든지 휩쓸릴 수 있는 가능성이 있고, 이러한 외교안보 구조적 압력을 완화시키기 위한 외교적 노력을 지속할 필요성이 있다. 그리고 타 국가들이 주저하는 속에서 주요 권역별 중심국가와 중진국 및 주요 개발도상 국들과의 관계 증진에 적극적으로 참여할 필요가 있다. 그리고 국내적으로는 많은 사람 들이 경제적 어려움을 겪고 있고, 사회적 갈등 상황도 지속되고 있다. 이러한 상황 속에 서 코로나 이후 디지털 기술을 기반으로 한 사회적 변화는 새로운 기회의 창출과 새로운 문화의 발전 가능성이 증대된다. 이러한 사회문화적 변화를 고려하여 국제문화교류 정책 의 재검토가 필요하다. 코로나 상황으로 인하여 그 활용도가 급격히 증가된 디지털 기술 의 활용도 고려한 국제문화교류 방안도 검토할 필요가 있다. 
코로나19 이후 국제문화교류 활성화방안 연구

\section{제3장}

국내외 국제문화교류 정책동향 



\section{제1절 코로나19 이후 국제문화교류 정책동향}

\section{1. 문화체육관광부 주요 계획 및 예산}

\section{가. 국제문화교류 정책 추진방향}

\section{1) 기존 국제문화교류 정책 기조}

문화체육관광부는 2018년 5월 '제1차 국제문화교류 진흥 종합계획(2018 2022)'을 발표하였다. 이는 「국제문화교류진흥법」(17년 9월 22일 시행)에 근거한 법정계획으로 5 년간 국제문화교류 정책의 기본 방향과 추진전략 및 세부과제를 제시하였다. 종합계획 추진은 교류형태가 일방향 교류에서 쌍방향 교류 또는 다자간 교류 방식으로 변화가 지 속되고, 교류분야 또한 기존의 순수예술전통문화 중심의 교류에서 문화전반, 정책교류 와 문화산업 분야까지 교류분야가 확장되어가는 추세가 배경이 되었다. 교류의 주체도 중앙정부와 공공기관에 지역 민간단체와 지방자치단체 등으로 확대되었다. 교류콘텐츠 또한 프로젝트 기반, 과정 중심의 교류로 변화되어가고, 4차 산업혁명에 따른 신기술 기 반의 창작협업 및 문화교류가 시도되고 있는 상황에서 한국 정부는 국제문화교류 진흥 을 위한 종합계획을 수립하게 되었다.

'세계와 공감하고 협력하여 모두가 행복한 국제문화교류'라는 비전 이래 네 가지 추진 전략을 설정하였다. 〈추진전략 1 〉은 국제문화교류 진흥 체계화로서 국제문화교류 정책 추진체계를 구축하고, 전담업무기관 지정 운영, 인프라 확충, 세종학당 활성화를 등을 주요 과제로 담았다. 〈추진전략 2〉는 국제문화교류 대상의 다양화로서 북방, 신남방, 한·중·일, 유네스코 등 주요 협력 대상과의 문화교류 협력 강화와 심화 등을 주요 과제 로 설정하였다. 〈추진전략 3〉은 지역과 민간의 국제문화교류 활성화로서 지역 문화예술 단체, 지방자치단체, 민간의 국제문화교류 사업 활성화 지원을 사업을 주요 사업으로 설 정하였다. 〈추진전략 4〉는 국제문화교류 기반 조성으로서 전문인력 양성, 종합정보시스 
템 구축, 실태조사 실시와 미래기술 활용 문화교류 사업 지원 등의 과제를 설정하였다.

[그림 3-1] '제1차 국제문화교류 진흥 종합계획' 정책목표 및 추진전략

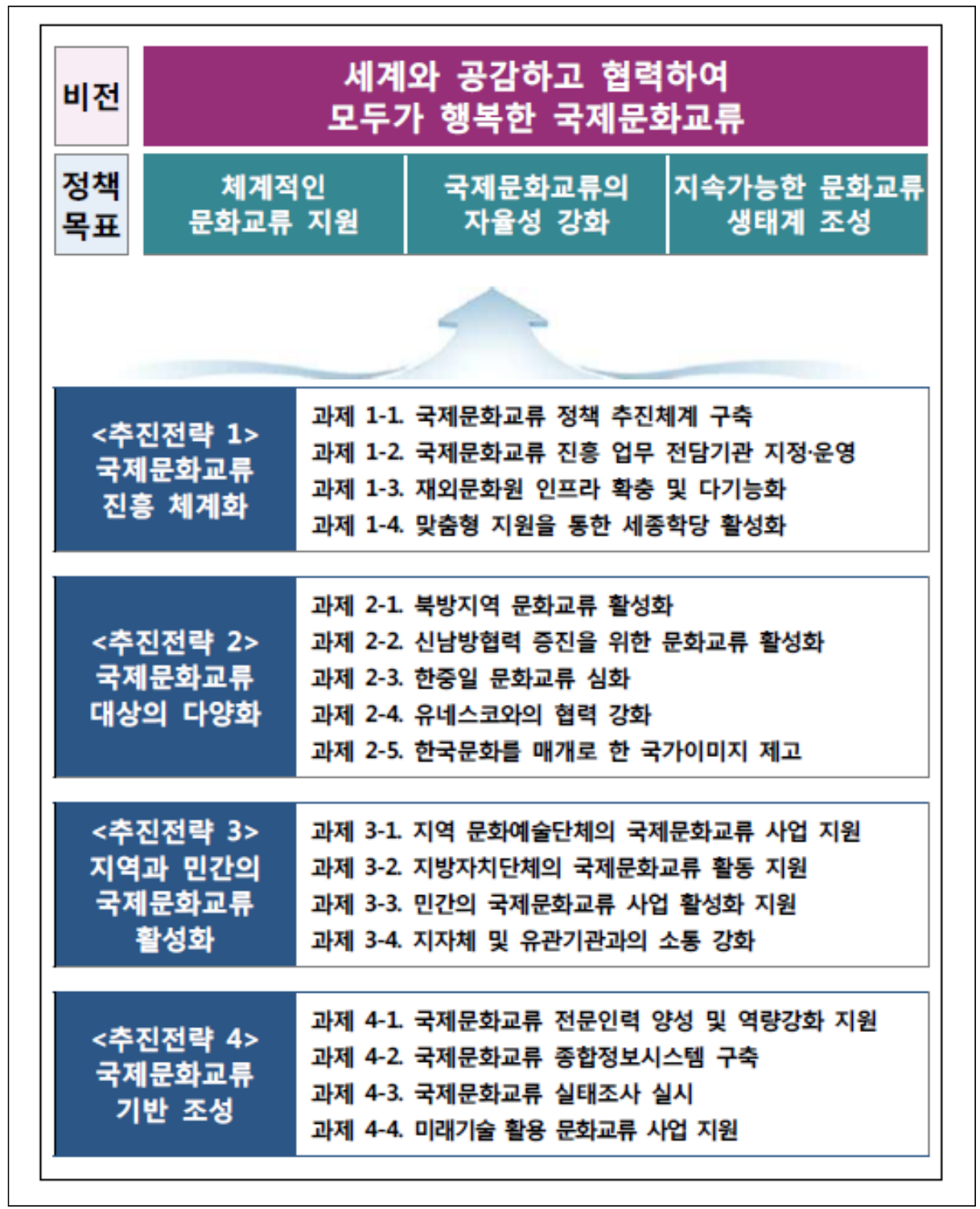

출처: 문화체육관광부. 2018.05. “제1차 국제문화교류진흥 종합계획(2018-2022)” p.8.

문화체육관광부는 제 1 차 국제문화교류 진흥 종합계획 수립 이후 사업 진행에 따라 아 래〈표 3-1〉와 같은 성과를 거두었다고 밝히고 있다. 정책추진체계 구축 과제로서 제1차 
국제문화교류 진흥 종합계획을 수립했고, 제 1 기 국제문화교류 진흥위원회를 구성하였으 며, 한국국제문화교류진흥원을 국제문화교류 전담 기관으로 지정하였다. 교류대상의 다 양화 과제로는 신남방. 신북방 국가와의 문화교류 확대, 북유럽·중동 등 기존에 교류가 활발하지 못했던 새로운 권역과의 교류 확대의 성과를 거두었다. 지역·민간의 국제문화교 류 과제로는 국제문화교류 워크솝을 실시하고 그 참가 범위를 확대하여 지자체, 민간, 주한외교단 등 다양한 행위자 간 업무협력과 조율의 장을 마련하고 한국의 주요 문화정책 을 소개하였다. 마지막으로 교류기반 구축과제로는 재외 한국문화원 확장, 유럽 문화홍보 거점으로서 파리 코리아센터 신설, 31 개국 34 개소로 세종학당 확대, 18 개국 주요 축제기관에 인력파견, 국제문화교류 종합정보시스템 '문화로' 구축 등의 성과를 거두었다.

〈표 3-1〉 '제1차 국제문화교류 진흥 종합계획' 성과

\begin{tabular}{c|l}
\hline \multirow{3}{*}{ 정책추진체계 구축 } & $\begin{array}{l}\text { - 제1차 국제문화교류 진흥 종합계획 수립('18.5) } \\
\text { - 제1기 국제문화교류 진흥위원회 구성 } \\
\text { - 한국국제문화교류진흥원을 국제문화교류 전담기관 지정 }\end{array}$ \\
\hline 교류대상의 다양화 & $\begin{array}{l}\text { - 신남방·신북방 국가와의 문화교류 확대 } \\
\text { - 북유럽(덴마크)·중동(UAE) 등 기존에 교류가 활발하지 못했던 새로운 권역 } \\
\text { 과의 교류 확대 }\end{array}$ \\
\hline \multirow{3}{*}{ 지역·민간의 국제문화교류 } & $\begin{array}{l}\text { - 국제문화교류 워크숍'(18.12/'19.4/'19.11) 참가범위를 확대하여 지자체 } \\
\text { (문화재단 등), 민간(문화예술 축제·문예회관), 주한외교단 등 다양한 행위 } \\
\text { 자 간 업무협력·조율*의 장 마련, 우리의 주요 문화정책을 소개 }\end{array}$ \\
\hline 교류기반 구축 & $\begin{array}{l}\text { - 재외한국문화원 확장(3개소 국유화) } \\
\text { - 유럽 문화홍보 거점인 파리 코리아센터 신설'(19.11) } \\
\text { - 세종학당 확대(31개국 34개소) } \\
\text { - 전문인력 양성(18개국 주요 축제·기관 파견) } \\
\text { - 국제문화교류 종합정보시스템 '문화로' 구축('19.4) }\end{array}$ \\
\hline
\end{tabular}

문화체육관광부. 2020.12. “제1차 국제문화교류진흥 종합계획(2018-2022)"개정판 p.3.

\section{2) 코로나19로 인한 국제문화교류 사업 추진의 어려움}

문화체육관광부는 위의 진흥계획에 따라 국제문화교류 사업을 진행해왔으나, 코로나 19 팬데믹 상황에 따라 국제문화교류 사업이 제대로 진행될 수 없게 되었다. 코로나 19 로 인하여 문화체육관광부는 국제문화교류사업을 제대로 진행할 수 없게 되었다. 아래의 〈표 3-2〉와 같이 문화체육관광부의 구체적인 교류사업이 많이 축소되었다. 2020년 8개 나 계획되었던 정부 간 교류사업이 2021년에는 3개 사업만이 계획되었다. 수교기념사 업 부분에서는 2020년에는 6개 국가와의 상호문화교류 행사가 계획되었고, 21년에는 
7개국과 수교기념 외교행사가 추진된다. 기타 상호교류, 유네스코 사업, 해외문화원 사 업 등이 2020년에는 진행되었으나, 2021년에는 문화 ODA사업만이 추진된다. 이처럼 수교기념행사를 제외하고 정부 간 교류나 기타 교류 사업에서 양적 축소가 확인 된다.

〈표 3-2〉문화체육관광부 20년, 21년 국제문화교류 업무계획 발췌

\begin{tabular}{|c|c|c|}
\hline & 2020년 & 2021년 \\
\hline $\begin{array}{l}\text { 정부간 } \\
\text { 교류 }\end{array}$ & $\begin{array}{l}\triangle \text { 한-0사세안 문화장관회의(10.20-22, 캄보디 } \\
\text { 아), } \triangle \text { 제 } 9 \text { 차 한-아세안+한·중·일 문화협력네트 } \\
\text { 워크(7월(잠정), 인니), } \triangle \text { 아시아문화주간(10월) } \\
\text { 통한 협력 활성화, } \triangle \text { 한-아세안 문화혁신포럼 정 } \\
\text { 례 개최, } \triangle \text { 한-아세안 영화기구 설립 } \\
\triangle \text { 한·중·일 문화장관회의(12.20 21, 일본), } \triangle \\
\text { 수교 30주년 기념 }\ulcorner 2021-2022 \text { 한-중 상호방 } \\
\text { 문의 해 준비, } \triangle 2020 \text { 도쿄올림픽 등 활용 3국 } \\
\text { 간 교류 지속 }\end{array}$ & $\begin{array}{l}\triangle^{\prime} 21 \text { 한 · 메콩* 교류의 해, } \triangle^{\prime} 20 \text { ‘ }^{\prime} 21 \text { 한 · 러 } \\
\text { 상호 문화교류의 해, } \triangle^{\prime} 21 \sim^{\prime} 22 \text { 한 · 중 문화 } \\
\text { 교류의 해 사업 추진 }\end{array}$ \\
\hline 수교기념 & $\begin{array}{l}\triangle \text { (러시아) 수교 30주년 기념 「2020-2021 한 } \\
\text {-러 상호 문화교류의 해 추진 } \\
\triangle \text { 수교 기념 국가(말레이시아, 스페인, 이집트, } \\
\text { 나이지리아)*와의 문화교류 행사, } \triangle \text { 아랍에미리 } \\
\text { 트 '상호 문화교류의 해' 개최 }\end{array}$ & $\begin{array}{l}\triangle 21 \text { 년 수교 기념 외교행사 추진 : 벨기에, 그 } \\
\text { 리스, 알바니아, 호주, 코트디부아르, 니제르, 피 } \\
\text { 지 }\end{array}$ \\
\hline 기타 & $\begin{array}{l}\text { (상호교류) } \triangle \text { 해외 공공도서관 조성-지원(2개국 } 8 \\
\text { 개관), } \triangle \text { 주요 해외박물관 한국실 지원(영국박물 } \\
\text { 관 등 3개관), } \triangle \text { 태권도 사범 파견 확대(40개국 } \\
\rightarrow 70 \text { 개국) } \\
\text { (유네스코) } \triangle \text { 한국의 갯벌(7월), 연등회(12월) 세 } \\
\text { 계유산 등재 및 } \triangle \text { 비무장지대(DMZ) 남북공동 } \\
\text { 등재 추진, } \triangle \text { 세계유산 해석 국제센터 설치(하반 } \\
\text { 기, 협정 체결) } \\
\text { (해외문화원) } \triangle \text { 권역별 협력사업 확대' } 19 \text { 년 } 7 \text { 개 } \\
\rightarrow 20 \text { 년 } 10 \text { 개), } \triangle \text { 문화원 신설(남아공) }\end{array}$ & $\begin{array}{l}\text { 몽골(관광종합교육센터 건립), 베트남(공공도서 } \\
\text { 관 건립) 등 수원국 맞춤형 문화 공적개발원조 } \\
\text { (ODA)의 차질없는 추진 } \\
\text { 경험지식 전수형 문화 공적개발원조(ODA, 문화 } \\
\text { 동반자 사업) 대상 확대 }\end{array}$ \\
\hline
\end{tabular}

〈표 3-3〉을 보면 문체부 문화예술해외교류 사업 결산결과 예산 집행률이 2019년에 는 집행률이 99.8\%인 반면, 2020년에는 집행률이 64.1\%로 떨어졌다. 국제문화교류사 업들이 중단되거나, 진행된 사업들도 비대면 방식으로 전환되거나 축소되어 진행되었기 때문에 예산집행률이 $30 \%$ 이상 하락하게 되었다. 코로나 19 의 확산으로 인한 단기대응 으로서 사업의 축소가 불가피 했다. 
〈표 3-3〉 문화예술 해외교류 관련 사업 결산내역

(단위 : 백만원, \%)

\begin{tabular}{|c|c|c|c|c|c|c|c|c|}
\hline \multirow[b]{2}{*}{ 연도 } & \multicolumn{2}{|c|}{ 예산액 } & \multirow{2}{*}{$\begin{array}{l}\text { 예산 } \\
\text { 현액 } \\
\text { (B) }\end{array}$} & \multirow{2}{*}{$\begin{array}{l}\text { 집행액 } \\
\text { (C) }\end{array}$} & \multirow{2}{*}{$\begin{array}{l}\text { 집행률 } \\
\text { (C/A) }\end{array}$} & \multirow{2}{*}{$\begin{array}{l}\text { 집행률 } \\
\text { (C/B) }\end{array}$} & \multirow{2}{*}{$\begin{array}{c}\text { 다음연도 } \\
\text { 이월액 }\end{array}$} & \multirow[b]{2}{*}{ 불용액 } \\
\hline & 본예산 & $\begin{array}{l}\text { 추경 } \\
\text { (A) }\end{array}$ & & & & & & \\
\hline 2017 & 2,622 & 2,622 & 2,622 & 2,142 & 81.7 & 81.7 & - & 480 \\
\hline 2018 & 3,541 & 3,541 & 3,541 & 3,227 & 91.1 & 91.1 & - & 314 \\
\hline 2019 & 3,152 & 3,152 & 3,152 & 3,145 & 99.8 & 99.8 & - & 7 \\
\hline 2020 & 2,850 & 2,850 & 2,850 & 1,827 & 64.1 & 64.1 & - & - \\
\hline
\end{tabular}

2020년 국제문화교류사업의 예산 집행률이 떨어지다 보니 2021년 사업계획에서 예 산규모가 축소될 수밖에 없었다. 〈표3-4〉에서는 2021년 예산이 27억 4천 5백만원으로 2020년 예산 28억 5천만원에 비해 1억 5백만원 감소하였다는 것을 보여준다.

〈표 3-4〉 문화예술 해외교류사업 예산

(단위 : 백만원, \%)

\begin{tabular}{c|c|c|c|c|c|c|c}
\hline \multirow{2}{*}{ 목명 } & \multirow{2}{*}{$\begin{array}{c}\text { 2019년 } \\
\text { 결산액 }\end{array}$} & \multicolumn{2}{|c|}{ 2020년 계획액 } & \multicolumn{2}{|c|}{ 2021년 } & \multicolumn{2}{|c}{ 증감 } \\
\cline { 3 - 6 } & 당초 & 수정(A) & 요구안 & 조정안(B) & (B-A) & $(\mathrm{B}-\mathrm{A}) / \mathrm{A}$ \\
\hline 문화예술 해외교류 & 3,145 & 2,850 & 2,850 & 2,745 & 2,745 & $\triangle 105$ & $\triangle 3.7$ \\
\hline
\end{tabular}

이상의 2020년 국제문화교류 사업 예산 현황에서 알 수 있듯이, 기존의 국제문화교류 사업들이 기존 형태대로 추진하기 어려운 상황이 되었다. 코로나 상황이 완화되었다고 하더라도, 전 세계적으로 완전한 종식이 선언되지 않는 이상 코로나 상황에 대비하여 사업을 기획해야 된다. 따라서 여러 가지 상황을 고려한 새로운 국제문화교류 방식에 대한 고민이 필요하며, 이를 선도적으로 준비할 필요성이 제기된다.

\section{3) 국제문화교류 진흥 종합계획 개정}

코로나19로 인한 상황변화에 맞추어 2020년 12월 문화체육관광부는 '제1차 국제문 화교류 진흥 종합계획(2018 2022)'을 개정하게 되었다. 코로나19로 인하여 국가 간 이 동에 제약이 발생하여 국제문화교류가 정상적으로 작동할 수 없는 상황이 되었다. 하지 만, 디지털 기술을 활용하여 비대면(Untact) 방식의 문화교류가 많이 이루어졌고, 이로 인해 향후 4 차 산업혁명 기술발전의 결과들에 기반하여 새로운 기술을 접목한 문화교류 
방식과 활동이 준비될 필요성이 제기되었다. 코로나19로 인한 활동과 교류의 제약이 완 전히 사라진다고 하더라도, 문화활동과 교류활동이 코로나 19 가 등장하기 이전으로 $100 \%$ 돌아갈 수는 없다. 새로운 기술을 접목한 문화교류 방식이 새로운 국제문화교류의 영역을 확장시키고, 더 많은 사람들이 국제문화교류활동을 시작할 수 있다.

개정된 국제문화교류 진흥 종합계획의 주요 개정 방향으로 3 대 전략이 제시되었다. 첫째, 전략적·체계적인 국제문화교류 기반 마련, 둘째, 국제문화교류 '새로운 기준' 선제 적 대응, 셋째, 국제문화교류의 지속가능한 생태계 구축이다. 전략적·체계적인 국제문화 교류 기반 마련을 위해서 지역.국가대상 및 한국 문화에 대한 인지도외교적 중요성에 따라 차별화된 문화교류 전략실행 계획을 수립하고자 하고 이를 위한 제도적·정책적 기 반 마련을 준비할 계획이다. 그리고 신북방신남방중국 등 전략적 문화교류 대상 국가에 대한 문화교류 활성화에 역량을 집중하고자 한다. 국제문화교류 '새로운 기준' 선제적 대응을 위해서는 전 세계적인 추세로 확산된 비대면 문화 활동을 반영한 국제교류 및 증강현실(AR) 등 실감 콘텐츠를 활용한 국제교류를 선도하는 새로운 방식의 창작·교류 활동을 지원하고자 하며, 단순 공연·전시교환이 아닌 공동창작·기획 및 민간단체(국민) 참여형 국제문화교류 등 주체형식.내용의 다변화를 추구하고자 한다. 마지막으로, 국제 문화교류의 지속가능한 생태계 구축을 위해서는 다양한 주체의 참여를 활성화하여 국제 문화교류 추진체계를 보완하고, 이를 위한 물적·인적 기반을 조성하고자 한다.

이 세 가지 정책목표를 달성하기 위하여 개정된 종합계획에는 세 가지 추진전략이 설 정되었다. 첫 번째 추진전략은 전략적·체계적 국제문화교류 기반 마련, 두 번째 추진전 략은 국제문화교류 “새로운 기준” 선제적 대응, 세 번째 추진전략은 국제문화교류의 지 속가능한 생태계 구축이다. 첫 번째 추진전략 하에는 세 가지 과제가 제시되었다. 첫 번 째 과제는 국제문화교류 전략 수립 및 기반 마련, 두 번째 과제는 국제사회 문화정책 리더십 발휘, 세 번째 과제는 주요 지역과의 실질적 문화협력 관계 구축이다. 
[그림 3-2] 개정 '제1차 국제문화교류 진흥계획' 정책 목표 및 추진전략

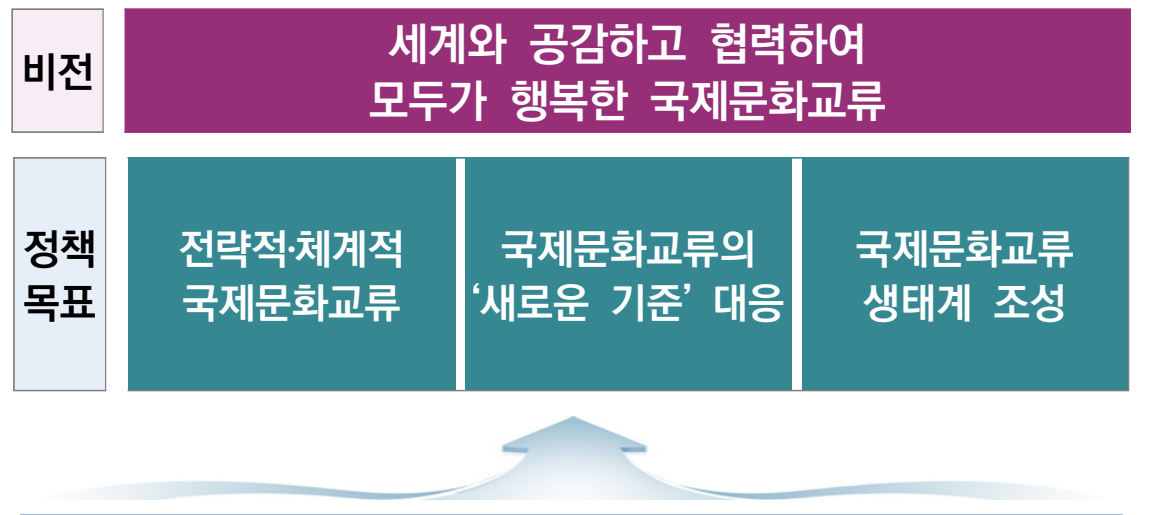

〈추진전략 1〉 전략적-체계적 국제문화교류 기반 마련
과제 1-1. 국제문화교류 전략 수립 및 기반 마련 과제 1-2. 국제사회 문화정책 리더십 발휘 과제 1-3. 주요 지역과의 실질적 문화협력 관계 구축
〈추진전략 2〉 국제문화교류 “새로운 기준" 선제적 대응
과제 2-1. 새로운 기술을 활용한 상생의 국제문화교류 추진 과제 2-2. 문화교류 내용과 방식의 다양화 과제 2-3. 국제문화교류 참여자 확대

\section{〈추진전략 3〉 국제문화교류의 지속가능한 생태계 구축}

과제 3-1. 국제문화교류 거버넌스 활성화

과제 3-2. 국제문화교류 물적.인적 기반 조성

두 번째 추진전략하의 과제는 세 가지이다. 첫 번째, 새로운 기술을 활용한 상생의 국제문화교류 추진, 두 번째, 문화교류 내용과 방식의 다양화, 세 번째, 국제문화교류 참여자 확대이다. 세 번째 추진전략 하에서의 과제는 두 가지이다. 첫 번째, 국제문화교 류 거버넌스 활성화, 두 번째, 국제문화교류 물적-인적 기반 조성이다. 이상의 개정된 국제문화교류 진흥 종합계획의 내용은 국제문화교류 정책을 전략적 체계적으로 추진하 
면서 좀 더 적극적으로 국제문화교류 환경변화에 대응하겠다는 의지를 담았다. 그리고 국내의 다양한 주체들이 국제문화교류 활동을 할 수 있는 환경 조성을 위한 노력도 포함 하였다.

\section{2. 시기별 사업현황}

코로나 전후 문화체육관광부가 주로 수행한 사업들의 현황을 정리하였다. 2019년과 2020 사업을 비교할 수 있도록 정리하였으며, 그 뒤 사업의 상세 현황을 제시한다.

\section{가. 2019년과 2020년 비교(코로나 전후)}

1) 전체 사업 건수 비교

2019년과 2020년 문화체육관광부 소속 기관 국제문화교류사업을 사업유형별로 나 누어 그 숫자를 비교해보았다. 영화상영/전시관련 사업은 2019년 6건에서 2020년 3건 으로 줄어들었다. 박람회/공연/행사 유형은 6건에서 9건으로 3건 늘어났다. 제작/출판/ 설치지원 유형은 5 건에서 2 건으로 줄었고, 네트워크 구축 사업은 1 건에서 3 건으로 증가 하였다. 축제/아트페어참가, 개최 사업 유형은 2019년 3건에서 2020년 4건으로 1건 늘어났다. 인력파견/초청/양성 사업은 12 건에서 21 건으로 증가하였다. 공모사업은 동 일하게 1건씩 기록되었다. 플랫폼 구축/교류사업은 2019년 4건에서 2020년 7건으로 증가하였다. 사업지원유형은 2019년 22건에서 2020년 18건으로 2건 줄었다. 자료교류 유형은 2019년 4건에서 2020년 2건으로 줄었다. 이상 유형별로 2019년과 2020년 국 제문화교류 사업 건수의 증감을 살펴보았다. 유형별로 전시, 공연, 박람회 등 행사를 중 심으로 이루어지는 사업 유형들의 사업 건수 감소가 눈에 띄고, 인력관련 사업이나 교류 사업 등은 늘어난 것은 비대면 방식이나 국내 자체 사업으로 진행할 수 있는 등 사업의 대체나 다른 방식으로 사업이 가능한 사업을 중심으로 국제문화교류 사업이 지속되고 있음을 알 수 있다. 
〈표 3-5〉2019년과 2020년 국제문화교류 사업 유형별 분류

\begin{tabular}{c|c|c|c|c|c|c|c|c|c|c}
\hline & $\begin{array}{c}\text { 영화상영 } \\
\text { /전시 } \\
\text { (지원) }\end{array}$ & $\begin{array}{c}\text { 박람회/ } \\
\text { 공연/ } \\
\text { 행사 }\end{array}$ & $\begin{array}{c}\text { 제작// } \\
\text { 출판/ } \\
\text { 설치지원 }\end{array}$ & $\begin{array}{c}\text { 네트워크 } \\
\text { 구축 }\end{array}$ & $\begin{array}{c}\text { 축제/ } \\
\text { 아트페어 } \\
\text { 참가, 개최 }\end{array}$ & $\begin{array}{c}\text { 인력파견 } \\
\text { /초청/ } \\
\text { 양성 }\end{array}$ & $\begin{array}{c}\text { 공모 } \\
\text { 플랫폼 } \\
\text { 구축/ } \\
\text { 교류사업 }\end{array}$ & 사업지원 & 자료교류 \\
\hline 2019 & 6 & 6 & 5 & 1 & 3 & 12 & 1 & 4 & 22 & 4 \\
\hline 2020 & 3 & 9 & 2 & 3 & 4 & 21 & 1 & 7 & 18 & 2 \\
\hline
\end{tabular}

다음은 기관별로 2019년과 2020년 국제문화교류 사업의 증감을 살펴보았다. 증가한 기관이 6개 이고, 5개 기관은 2019년에 사업을 시행하지 않았고, 2020년에 새로 사업 을 진행하였다. 증가한 기관명은 국립중앙박물관, 국립현대미술관, 국립아시아문화전당, 국제방송교류재단, 세종학당재단, 한국문화예술위원회이다. 2020년 신규로 사업을 진 행한 기관은 저작권위원회, 국립국악원, 국립중앙극장, 해외문화홍보원, 한국출판문화산 업진흥원 5개 기관이다. 2019년과 2020년 동일한 사업 건수를 유지한 기관은 3개 기관 이며, 국립중앙도서관, 아시아문화원, 영화진흥위원회이다.

2019년에 비해 2020년 국제문화교류 사업이 감소한 기관은 9개 기관이다. 예술경영 지원센터, 한식진흥원, 한국전통공연예술진흥재단, 한국국제문화교류진흥원, 한국문학 번역원, 한국공예디자인문화진흥원, 한국콘텐츠진흥원, 한국문화예술교육진흥원, 한국 문화정보원이다. 이 중에서 2020년 사업이 한 건도 없었던 기관도 3 개 기관이 있다. 한 식진흥원, 한국문학번역원, 한국문화정보원이 2020년에는 국제문화교류 사업이 하나도 진행되지 않았다. 이러한 국제문화교류 사업 진행에서의 기관별 차이는 전체적인 국제문 화교류 사업의 추진 여부와 대응방식에 대한 정보공유나 조율이 없는 속에서 기관별 각 자 판단에 따라 국제문화교류사업의 진행과 중단 여부가 결정되었기 때문이다.

〈표 3-6〉2019년과 2020년 기관별 사업건수 비교

\begin{tabular}{c|c|c|c}
\hline & 2019년 & 2020년 & 비교 \\
\hline 국립중앙박물관 & 2 & 5 & 증가 \\
\hline 국립중앙도서관 & 2 & 2 & 유지 \\
\hline 국립현대미술관 & 2 & 7 & 증가 \\
\hline 국립아시아문화전당 & 1 & 2 & 증가 \\
\hline 예술경영지원센터 & 6 & 4 & 감소 \\
\hline 한식진흥원 & 5 & 0 & 감소 \\
\hline 국제방송교류재단 & 1 & 4 & 증가 \\
\hline
\end{tabular}




\begin{tabular}{c|c|c|c}
\hline & 2019 년 & 2020 년 & 비교 \\
\hline 세종학당재단 & 3 & 5 & 증가 \\
\hline 아시아문화원 & 1 & 1 & 유지 \\
\hline 영화진흥위원회 & 2 & 2 & 유지 \\
\hline 한국전통공연예술진흥재단 & 5 & 2 & 감소 \\
\hline 한국국제문화교류진흥원 & 10 & 6 & 감소 \\
\hline 한국문학번역원 & 1 & 0 & 감소 \\
\hline 한국공예디자인문화진흥원 & 3 & 1 & 감소 \\
\hline 한국콘텐츠진흥원 & 8 & 1 & 감소 \\
\hline 한국문화예술교육진흥원 & 6 & 1 & 감소 \\
\hline 한국문화예술위원회 & 5 & 7 & 증가 \\
\hline 한국문화정보원 & 1 & 0 & 감소 \\
\hline 저작권위원회 & 0 & 2 & 신규 증가 \\
\hline 국립국악원 & 0 & 6 & 신규 증가 \\
\hline 국립중앙극장 & 0 & 2 & 신규 증가 \\
\hline 해외문화홍보원 & 0 & 4 & 신규 증가 \\
\hline 한국출판문화산업진흥원 & 0 & 1 & 신규 증가 \\
\hline
\end{tabular}

\section{2) 주요사업 중심 비교}

국제문화교류사업을 코로나19 전후로 비교하여 특징과 시사점을 살펴보면 다음과 같다. 첫째, 2020년에는 기획(계획)된 사업이 취소된 사업은 많지 않다. 다만 한·중·일 문화 장관회의와 동아시아 문화도시 한중일 공동추진은 2021년에 다시 진행하기로 했 다. 계획된 사업을 진행하지 않을 경우, 예산 사용의 문제, 계기성 사업의 경우 당해연도 에 시행하지 않으면 사업의 효과와 사업 취지의 퇴색 등이 고려된 것으로 보인다.

둘째, 대부분의 사업이 온라인 비대면으로 전환되었다. 문화동반자 사업 같은 국제 인 력교류사업뿐 아니라 교류행사 역시 거의 비대면으로 바꿔 진행하였다. 국제간 이동이 현실적으로 불가한 상황에서 대면 접촉에 따른 교류사업을 진행할 수 없었던 것이다. 눈여겨 볼 점은 “트래블링 코리안 아츠”의 온라인 전시에서 가상현실(VR) 기술을 활용하 여 온라인의 약점을 넘어서고자 한 것이다. 향후 대면이든 비대면이든 기술과 접목된 국제교류는 늘어날 것으로 보인다.

셋째, 향후 코로나19 팬데믹 상황을 벗어나면, 대면 교류가 활성화가 추진될 것이다. 하지만, 코로나 상황 속에서 발전한 온라인 비대면 방식의 국제교류 사업 또한 대면 사 
업과 다른 사업 효과를 기대할 수 있고, 코로나 대응 기간 동안 확보한 관련 시스템과 예산 등을 유지하고자 할 것으로 예상되기 때문에 코로나 상황이 극복된 이후에도 온라 인 교류 사업은 지속될 것으로 보인다.

〈표 3-7〉 2019년과 2020년 주요 국제문화교류사업 비교

\begin{tabular}{|c|c|c|c|}
\hline & & 2019 & 2020 \\
\hline \multirow{2}{*}{$\begin{array}{l}\text { 국제문 } \\
\text { 화교류 } \\
\text { 지원 } \\
\text { 체계 }\end{array}$} & $\begin{array}{l}\text { ‘문화로' } \\
\text { 종합정보시스템 }\end{array}$ & \multicolumn{2}{|c|}{ 2019년 4월 3일부터 시작해서 계속 } \\
\hline & 전문인력 양성 & $\begin{array}{l}\text { - 대상 세분화하여 } 13 \text { 개국 } 13 \text { 개 기관과 } \\
\text { 협력하여 파견 }\end{array}$ & $\begin{array}{l}\text { - 해외 파견이 어려워 국내 현장을 중심 } \\
\text { 으로 추진 } \\
\text { - 'NEXT 온라인 아카데미' 새롭게 추진 }\end{array}$ \\
\hline \multirow{4}{*}{$\begin{array}{l}\text { 주요 } \\
\text { 국제문 } \\
\text { 화교류 }\end{array}$} & $\begin{array}{l}\text { 수교, 순회 } \\
\text { 문화행사 }\end{array}$ & $\begin{array}{l}\text { - 한-덴마크 상호문화의 해 } \\
\text { - 한-헝가리 수교 } 30 \text { 주년 } \\
\text { - 한-브라질 수교 } 60 \text { 주년 } \\
\text { - 한-필리핀 상호교류의 해 } \\
\text { - 쿠웨이트 수교 } 40 \text { 주년 } \\
\text { - UAE 순회 문화행사 } \\
\text { - 한-폴란드 수교 30주년 }\end{array}$ & $\begin{array}{l}\text { - 한국-아랍에미리트(UAE) 상호 문화교 } \\
\text { 류의 해(비대면 공연·전시) } \\
\text { - 한국-러시아 상호 문화교류의 해(대면· } \\
\quad \text { 비대면 혼합) }\end{array}$ \\
\hline & $\begin{array}{l}\text { 권역별·국가별 } \\
\text { 문화교류 }\end{array}$ & $\begin{array}{l}\text { - 한-중·일 문화장관회의(한국 인천에서 } \\
\text { 개최) } \\
\text { - 동아시아문화도시: 한국 인천시, 일본 } \\
\text { 도쿄 도시마구, 중국 시안시 선정 } \\
\text { - 한일문화교류회의: 한일합동공연 '동행 } \\
\text { (同行' 오사카에서 진행 } \\
\text { - 한중일문화교류모럼 도쿄 진행 } \\
\text { - 한-아세안 특별문화장관회의 광주 국 } \\
\text { 립아시아문화전당 } \\
\text { - 트래블링 코리안 아츠: } 6 \text { 개국 } 22 \text { 개 도 } \\
\text { 시 총 } 284,985 \text { 명 관람 }\end{array}$ & $\begin{array}{l}\text { - 한·중·일 문화장관회의(일본 기타큐슈 } \\
\text { 개최 예정이었으나 연기) } \\
\text { - 동아시아문화도시: } 2019 \text { 년 선정된 한 } \\
\text { 국 인천시, 일본 도쿄 도시마구, 중국 } \\
\text { 시안시 1년 연장 } \\
\text { - 한일문화교류회의: 한일합동공연 '동행 } \\
\text { (同行)' 온라인과 세미나 진행 } \\
\text { - 한중일문화교류포럼: 온라인 서예전 개 } \\
\text { 최 } \\
\text { - 아세안+3 문화장관회의·한-아세안 문화 } \\
\text { 장관회의(격년개최): 캄보디아 프놈펜 } \\
\text { 개최 예정이었으나 비대면 화상회의 } \\
\text { - 주요 20개국(G20) 문화장관: 비대면 } \\
\text { 화상회의 } \\
\text { - 한-유럽연합(EU) 문화협력위원회: 벨 } \\
\text { 기에 개회 예정이었으나 비대면 화상 } \\
\text { 회의 } \\
\text { - 트래블링 코리안 아츠: 공연과 전시 프 } \\
\text { 로그램 온라인 진행 }\end{array}$ \\
\hline & $\begin{array}{l}\text { 국제문화교류로 } \\
\text { 인해 국민 } \\
\text { 문화향유권 } \\
\quad \text { 증진 }\end{array}$ & $\begin{array}{l}\text { - 제1회 국제문화교류 합동 워크숍 } \\
\text { - 제2회 주한외교단 국제문화교류 합동 } \\
\text { 워크숍 }\end{array}$ & $\begin{array}{l}\text { - ‘2021-2022년 수교계기 기념 국가 실 } \\
\text { 무협의회’ 개최 } \\
\text { - 국제문화교류협의체 비대면 합동회의 }\end{array}$ \\
\hline & $\begin{array}{l}\text { 민간협업 } \\
\text { 문화교류 }\end{array}$ & $\begin{array}{c}-10 \text { 개 사업이 공모를 통해 선정되어 } 9 \\
\text { 개국 } 12 \text { 개 도시에서 공연:전시 }\end{array}$ & $\begin{array}{l}\text { - 8개 사업이 공모를 통해 선정되어 5개 } \\
\text { 국 8개 도시에서 공연:전시 }\end{array}$ \\
\hline
\end{tabular}




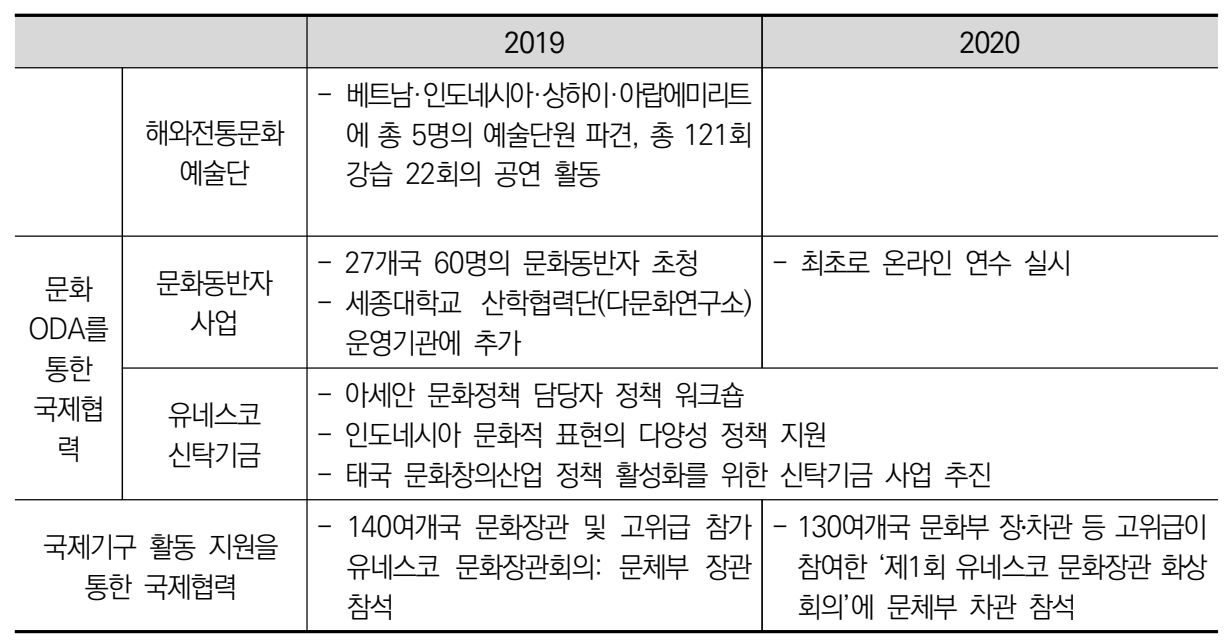

\section{나. 2019년 국제문화교류 사업}

\section{1) 전체 사업 현황}

코로나19 이후 국제문화교류사업의 어려움을 확인하고자 한다면, 코로나19 팬데믹이 발생하기 이전의 국제문화교류 사업 현황과 2020년 국제문화교류 사업현황을 비교해보면 상황변화의 정도를 알 수 있을 것이다. 대상 사업은 문화체육관광부에서 운영하는 국제문화 교류 종합정보시스템 '문화로(영문명 K-Culture Road, www. kcultureroad.kr)'에서 집계 된 교류사업 중 문체부 소속 기관의 문화예술분야 사업을 중심으로 정리하였다.105) 2019년 국제문화교류사업은 총 63건으로 파악되었다. 문화산업, 예술, 전통문화 등 의 분야를 중심으로 사업이 진행되었다. 수행기관은 총 18 개 기관이다. 기관별로 진행한 사업의 건수를 살펴보면, 국립중앙박물관 2건, 한국공예디자인문화진흥원 3건, 한국콘 텐츠진흥원 8건, 한국문화예술교육진흥원 6건, 한국문화예술위원회 5건, 한국문화정보 원 1건, 예술경영지원센터 6건, 한식진흥원 5건, 국립중앙도서관 2건, 국립현대미술관 2건, 국제방송교류재단 1건, 세종학당재단 3건, 아시아문화원 1건, 영화진흥위원회 2건, 전통공연예술진흥재단 5건, 한국국제문화교류진흥원 10건, 한국문학번역원 1건, 국립 아시아문화전당 1 건으로 집계되었다.

105) 국제교류사업을 진행하는 문체부 산하 기관 중 10 개 기관의 서면자문에서 대부분의 기관들의 문화로의 사업 집계현황에서 자신들의 교류 사업이 누락되어있다는 점을 지적하였다. 
〈표 3-8〉2019년 국제문화교류사업 분류

\begin{tabular}{|c|c|c|c|c|c|c|c|c|c|c|c|c|c|c|c|}
\hline & $\begin{array}{l}\text { 영화 } \\
\text { 상영 } \\
\text { / } \\
\text { 전시 } \\
\text { /전 } \\
\text { 시실 } \\
\text { 설치 }\end{array}$ & $\begin{array}{c}\text { 박람 } \\
\text { 회 } \\
\text { 참가 } \\
\text { 지원 }\end{array}$ & $\begin{array}{c}\text { 콘텐 } \\
\text { 츠 } \\
\text { 제작 } \\
\text { 지원 }\end{array}$ & $\begin{array}{l}\text { 네트 } \\
\text { 워크 } \\
\text { 구축 } \\
\text { 및 } \\
\text { 동향 } \\
\text { 조사 }\end{array}$ & $\begin{array}{l}\text { 외국 } \\
\text { / } \\
\text { 국내 } \\
\text { 축제 }\end{array}$ & $\begin{array}{c}\text { 인력 } \\
\text { 파견 } \\
\text { / 초청 }\end{array}$ & $\begin{array}{c}\text { 해외 } \\
/ \\
\text { 국내 } \\
\text { 공모 }\end{array}$ & $\begin{array}{l}\text { 해외 } \\
\text { 행사 } \\
\text { 참가/ } \\
\text { 출판/ } \\
\text { 초청 } \\
\text { 전시 } \\
\text { 지원 }\end{array}$ & $\begin{array}{c}\text { 플랫 } \\
\text { 폼 } \\
\text { 구축 }\end{array}$ & $\begin{array}{l}\text { 아카 } \\
\text { 이브 } \\
\mathrm{DB} \\
\text { 확산 }\end{array}$ & $\begin{array}{l}\text { 교류 } \\
\text { 사업 }\end{array}$ & $\begin{array}{l}\text { 레지 } \\
\text { 던시 }\end{array}$ & $\begin{array}{l}\text { 교류 } \\
\text { 센터 } \\
\text { 설치 }\end{array}$ & $\begin{array}{l}\text { 사업 } \\
\text { 지원 }\end{array}$ & 합계 \\
\hline 국립중앙박물관 & 2 & & & & & & & & & & & & & & 2 \\
\hline $\begin{array}{c}\text { 한국공예디자인 } \\
\text { 문화진흥원 }\end{array}$ & 1 & 1 & & & & & & & & & 1 & & & & 3 \\
\hline $\begin{array}{c}\text { 한국콘텐츠 } \\
\text { 진흥원 }\end{array}$ & & & 5 & & & & & 1 & & & & & & 2 & 8 \\
\hline $\begin{array}{c}\text { 한국문화예술 } \\
\text { 교육진흥원 }\end{array}$ & & . & . & 2 & 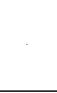 & 3 & . & 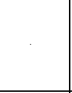 & . & . & . & . & 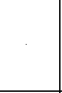 & 1 & 6 \\
\hline $\begin{array}{c}\text { 한국문화예술 } \\
\text { 위원회 }\end{array}$ & & . & . & 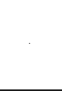 & 1 & 3 & . & . & . & . & 1 & 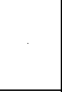 & 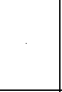 & . & 5 \\
\hline 한국문화정보원 & & & & & & 1 & & & & & & & & & 1 \\
\hline $\begin{array}{c}\text { 예술경영지원 } \\
\text { 센터 }\end{array}$ & & & 1 & & & & 1 & 3 & 1 & & & & & & 6 \\
\hline 한식진흥원 & & & & 1 & 1 & 2 & & & & 1 & & & & & 5 \\
\hline 국립중앙도서관 & 1 & & & & & & & & & & 1 & & & & 2 \\
\hline 국립현대미술관 & 1 & 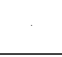 & . & . & 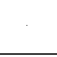 & 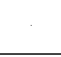 & . & 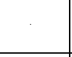 & . & 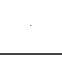 & 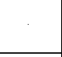 & 1 & 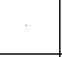 & . & 2 \\
\hline $\begin{array}{c}\text { 국제방송교류 } \\
\text { 재단 } \\
\end{array}$ & & & & & & & . & & . & & 1 & . & & & 1 \\
\hline 세종학당재단 & & & & & & 1 & & & 1 & & & & & 1 & 3 \\
\hline 아시아문화원 & . & . & & & & & & & & & & 1 & & & 1 \\
\hline 영화진흥위원회 & 1 & . & . & . & 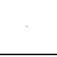 & . & . & 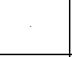 & . & . & 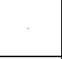 & & 1 & & 2 \\
\hline $\begin{array}{c}\text { 전통공연예술 } \\
\text { 진흥재단 }\end{array}$ & 1 & : & . & . & . & 1 & . & 3 & . & 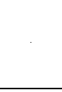 & . & . & & 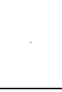 & 5 \\
\hline $\begin{array}{c}\text { 한국국제문화 } \\
\text { 교류진흥원 }\end{array}$ & & & 1 & 1 & & 3 & & & & & 2 & & 1 & 2 & 10 \\
\hline 한국문학번역원 & . & . & . & 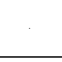 & 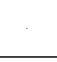 & 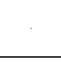 & 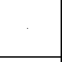 & . & 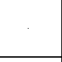 & . & 1 & . & 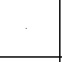 & . & 1 \\
\hline $\begin{array}{l}\text { 국립아시아 } \\
\text { 문화전당 }\end{array}$ & & & & & & & & & & & 1 & & & & 1 \\
\hline 합계 & 7 & 1 & 7 & 4 & 2 & 14 & 1 & 7 & 2 & 1 & 8 & 2 & 2 & 6 & \\
\hline
\end{tabular}


사업을 카테고리별로 분류해보면 영화상영/전시/전시실 설치 사업은 7건, 박람회 참가 지원은 1 건, 콘텐츠 제작지원은 7 건, 네트워크 구축 및 동향조사사업은 4건, 외국/국내 축제참가 사업은 2 건, 인력파견/초청사업은 14 건, 해외/국내공모사업은 1 건, 해외행사 참가/출판/초청 지원 사업은 7 건, 플랫폼 구축사업은 2 건, 아카이브 $\mathrm{DB}$ 확산 사업은 1 건, 교류사업은 8건, 레지던시 사업은 2건, 교류센터 설치사업은 2건, 지원사업은 6건 이다.

\section{2) 국제문화교류 주요사업 유형}

(1) 수교계기 문화행사 개최

$\bigcirc$ 한-덴마크 상호문화의 해, 한-헝가리 수교 30주년 기념 문화행사

한국-덴마크 수교 60주년인 2019년을 '상호문화의 해’로 지정하고 다양한 문화행사 를 개최하였다. 덴마크 코펜하겐의 블랙다이아몬드 퀸즈홀에서 월드뮤직 그룹 고래야와 $\mathrm{PMC}$ 프로덕션의 〈난타〉, 2 개 작품이 공연하였고, 다양한 한국문화를 경험할 수 있는 기 회를 제공하기 위해 덴마크 코펜하겐 DR 콘서트홀 스튜디오2에서 한국 전통음악 공연 개최하였다. 한국-덴마크 상호문화의 해, 한국-헝가리 수교 30주년을 기념하여 국 립무용단의 〈묵향〉 공연되었다.

〈표 3-9〉 수교계기 문화행사 주요 추진실적 총괄 표(2019)

\begin{tabular}{|c|c|c|c|}
\hline \multirow[t]{2}{*}{ 한·덴마크 상호문화의 해 } & $\begin{array}{l}\text { 난타/고래야 공연 } \\
\text { (넌버벌/ 창작국악) }\end{array}$ & 3월 & $\begin{array}{l}\text { 덴마크 외무부 차관, 주요 외교단(독일, 프랑스, } \\
\text { 스페인, 등) 문화예술 관계자, 일반 관객 등 } 380 \\
\text { 여명 관람 }\end{array}$ \\
\hline & 국립부산국악원 공연 & 12월 & $\begin{array}{l}\text { 코펜하겐대학교 한국학과, 문화예술 관계자, 일반 } \\
\text { 관객 등 } 180 \text { 여명 관람 }\end{array}$ \\
\hline $\begin{array}{l}\text { 한·덴마크 상호문화의 해/ } \\
\text { 한·헝가리 수교 } 30 \text { 주년 }\end{array}$ & 국립무용단 〈묵향〉 공연 & 4월 & $\begin{array}{l}\text { 덴-한 소사이어티 대표, 덴마크 외무부사, 헝가리 } \\
\text { 상원의원(친한), 헝가리 한류재단, 문화예술 관계 } \\
\text { 자, 일반 관객 등 } 1,046 \text { 여명 }\end{array}$ \\
\hline 한·브라질 수교 60주년 & 국립현대무용단 공연 & 9월 & $\begin{array}{l}\text { 상파울루 시립극장 예술감독, 상파울루 시립발레 } \\
\text { 단 예술감독, 문화예술 관계자, 일반 관객 등 } \\
2,019 \text { 여명 관람 }\end{array}$ \\
\hline \multirow[b]{2}{*}{ 한·필리핀 상호교류의 해 } & $\mathrm{K}-\mathrm{POP}$ 공연 & 3월 & $\begin{array}{l}\text { 정·관계 주요 인사, 주요 문화예술 관계자, 일반 } \\
\text { 관객 등 } 3,000 \text { 여명 관람 }\end{array}$ \\
\hline & 필리핀 한국영화제 & 11월 & $\begin{array}{l}\text { 문화예술 관계자, 필리핀 영화진흥위원회 국제부 } \\
\text { 필리핀국립대학 영화학부, 일반관객 등 1만 5천 } \\
\text { 여명 }\end{array}$ \\
\hline
\end{tabular}


한-브라질 수교 60주년 문화예술 행사

한국-브라질 수교 60 주년을 기념하여 양국 간 협력을 강화하고 한국의 우수한 문화를 현지 사회에 널리 알리기 위해 상파울루 시립극장에서 국립현대무용단의 〈검은 돌: 모래 의 기억 공연을 무대에 올렸다.

$\bigcirc$ 한-필리핀 상호교류의 해

한국-필리핀 수교 70주년인 2019년을 ‘한-필리핀 상호교류의 해’로 지정하여 다양한 문화행사를 개최하였다. 개막행사로 한-필리핀 K-POP 우정콘서트를 3월 7일 필리핀 마닐라 $\mathrm{MOA}$ 아레나에서 개최하였다. 11 월 6 일부터 8 일까지는 상호교류의 해 기념 '필리핀 한국영화제'를 필리핀 마닐라를 비롯한 7개 도시(다바오, 세부, 일로일로, 카 비테, 올라가포, 팜팡가 등)에서 개최하였다.

쿠웨이트 수교 40주년 / UAE 순회 문화행사

10 월 24일에는 아랍에미리트(UAE) 아부다비 국립극장에서 한국 음악 콘서트를 개 최하였고, 10 월 27일에는 쿠웨이트 압둘 후세인 압둘리다 극장에서 한국-쿠웨이트 외교 관계 수립 40 주년 기념하여 같은 공연을 개최하였다.

한-폴란드 수교 30주년 기념 문화행사

한국-폴란드 수교 30 주년을 기념하여 12 월 폴란드 바르샤바에서 국립국악관현악단 〈격格, 한국의 멋〉 공연이 개최되었다.

(2) 권역별·국가별 문화교류

한·중·일 문화장관회의

2019년에는 한국 인천에서 개최되었으며, 지난 10회에 걸친 한·중·일 문화장관의 성 과를 돌아보고 향후 한·중·일 3국의 문화교류 협력을 확대·발전시키기 위한 공동합의문 인 '인천 선언문'을 채택하였다. 3국이 연이어 올림픽을 개최(2018 평창, 2020 도쿄, 2022 베이징)하는 것을 계기로 평창올림픽·패럴림픽 때와 같이 공동 문화프로그램을 통 한 협력 증진 방안도 지속적으로 추진하기로 했으며, 성공적인 협력 모델 역할을 해온 국립박물관, 국립미술관 간 협력을 높이 평가하며 민간 예술 기관 간의 교류협력도 장려 하기로 했다. 


\section{동아시아문화도시 한·중·일 공동 추진}

2019년 동아시아문화도시는 한국의 인천시, 일본 도쿄 도시마구, 중국 시안시가 선정 (2018년 제10회 한·중·일 문화장관회의, 중국 하얼빈)되었으며, 1 월 도시마구, 3 월 시 안, 4월 인천 개막식을 시작으로 다채로운 문화교류 사업을 추진하였다. 예술인, 시민, 청소년들이 직접 참여하면서 서로의 문화를 경험하고 소통하며 이해의 폭을 넓혀 갔으 며 11월 문화협력 교류 확대를 위한 지속적인 문화교류와 발전방안 등을 담은 ‘동아시아 문화도시 2019 공동선언문'을 체결하여 향후 지속적인 교류의 확대와 상호 협력의 강화 하는 계기를 마련했다.

$\bigcirc$ 한일문화교류회의 운영

한일문화교류회의는 1999 년 3월 서울에서 개최된 한일 정상회담에서의 합의에 따라 한일 양국 간 문화교류 강화와 상호 이해 및 신뢰 구축을 위해 발족되었다. 현재 3기 위원(한일 각각 11 명)이 활동하고 있으며, 주요 사업으로는 한일 양국 전체회의 및 한일 합동 예술공연 개최, 국제 학술 심포지엄 및 세미나 개최, 한중일 문화교류포럼 운영, 문화교류 정책보고서 발간 등이 있다. 2005년부터 한중일 3 개국에서 매년 순차 개최하 고 있는 한중일문화교류포럼은 2020 도쿄올림픽 개최를 기념하여 일본 도쿄에서 '아시 아를 잇는 현( 弦)의 울림'이라는 주제로 한중일 3국을 대표하는 현악기(가야금, 고토, 고금) 전문가를 초청하여 특별강연 및 연주회를 개최하였다.

○ 2019 한-아세안 특별문화장관회의

한·아세안 대화관계 수립 30주년을 기념하고 한-아세안 문화예술분야 협력을 강화하 기 위해, 한·아세안 특별정상회의(11.25. 26, 부산) 사전 대화의 장으로 '한-아세안 특 별문화장관회의'가 2019년 10월 광주 국립아시아문화전당에서 개최되었다.

'사람 중심의 평화와 상생번영의 미래공동체 실현'을 위한 한-아세안 문화협력의 비 전을 공유하고 (1) 상호 문화 이해 증진, (2) 공동 창작 활성화, (3) 문화산업 협력, (4) 문화 유산 보존·활용 협력, (5) 문화예술기관 협력강화 등 5 개 분야의 협력 방안과 분야별 세 부 협력(안)을 마련하는데 합의했다.

○ 우수프로그램 권역별 순회 지원 "트래블링 코리안 아츠"

'트래블링 코리안 아츠'는 한국의 우수한 문화예술을 알리고 한국 문화예술의 해외 진 출을 확대하기 위하여 공연, 전시 등 우수 프로그램을 선정하여 해외 권역별로 순회하는 
사업으로 2015년부터 시작하였다. 공연예술과 시각예술 분야가 격년제로 추진되며 2019년은 공연분야로 진행, 10월 서울아트마켓 기간에 맞추어 총 10 개국에서 24 명이 방문하여 한국의 공연예술 현장을 살펴보고 프로그램 풀 기획자들과 향후 사업기획을 협의하였다.

(3) 국제문화교류와 협력을 바탕으로 국민 문화향유권 증진

문화체육관광부는 2019년 주한 외교단과 상시적인 관계망을 구축하고 한국의 주요 문화정책·행사를 널리 알리며, 국내·국제문화교류 네트워크를 보다 강화하기 위해 상/ 하반기 각1회씩 주한외교단을 초청하여 ‘주한외교단 국제문화교류 합동 워크솝’을 개최 하였다.

(4) 민간협업 문화교류

민간협업 문화교류 사업은 지역의 국제문화교류 역량을 강화함으로써 교류 기반을 확 대하기 위해 전국 기초지자체 소재 문화예술기관.단체의 우수 콘텐츠를 발굴, 지원하는 사업으로 2019년에는 경기 광명시(광명문화재단)의 '국제 업사이클아트 디자인 전시', 경북 고령군(고령문화원)의 '가야금, 마당놀이 풍동전' 등 지역 고유의 문화자원을 활용 한 우수 콘텐츠 10 개가 공모를 통해 선정되어 9 개국 12 개 도시에 선보였다.

(5) 해외전통문화예술단

해외전통문화예술단은 해외에 한국 전통예술을 소개·확산하고, 청년 예술인들의 글로 벌 역량을 강화하고자 현지인을 대상으로 가야금, 장구, 부채춤 등 전통예술 강습과 공 연을 지원하는 사업으로 2004년 시범사업을 시작하였다. 2019년에는 베트남·인도네시 아·상하이·아랍에미리트에 총 5 명의 예술단원을 파견, 총 121 회의 강습과 22 회의 공연 활동을 했으며 (재)국악방송과 협력하여 역량 있는 신진전통예술단체 '신민속악회 바디' 를 아랍에미리트에 파견하였다.

(6) 문화동반자 사업

2019년 문화동반자 사업은 27 개국 60명의 문화동반자를 초청하여 전통예술·무용·문 화유산·무대기술 등의 분야에서 역량강화를 위한 연수과정을 진행하였다. 특히 세종대 
학교 산학협력단(다문화연구소)이 새롭게 운영기관으로 들어오면서 운영기관 구성이 더 욱 안정화되었고 기동반자들에게 '후속 사업'도 지원하고 있다. 우즈베키스탄(타슈켄트) 에서 개최된 '도서관 전자 자료 개발 토론회'에는 도서관 사서의 역량강화를 위해 한국 의 국립중앙도서관 관계자 및 학계 전문가가 참여하여 한국의 전자 자료 구축 현황 및 기술을 전수하였고, 스리랑카(콜롬보)에서 개최된 '한국-스리랑카 전통 예술가 토론회' 에는 국립남도국악원 단원들이 참가하여 양국 간 전통음악을 통한 국가 간 문화교류에 기여하였다. 또한 몽골에서 첫 동창회를 개최하여 몽골 내 문화동반자 네트워크 확대 및 양국간 지속교류 계기를 마련하였다. 한편, 한-아세안 특별정상회의를 기념하여 개최 된 '한-아세안 미래특급' 사업에 한국문화재재단 동반자들이 참여하여 한국의 다양한 문 화체험 및 아세안 문화 교류활동에 참여하기도 하였다.

〈표 3-10〉 문화동반자 직접사업 내역(2019)

\begin{tabular}{|c|c|c|c|c|}
\hline 사업명 & 주관기관 & 주요 사업내용 & $\begin{array}{l}2019 \text { 예산 } \\
\text { (백만 원) }\end{array}$ & 인원 \\
\hline $\begin{array}{c}\text { TEPT } \\
\text { (Transcultural } \\
\text { Encounter Project } \\
\text { with Trust) }\end{array}$ & 트러스트무용단 & $\begin{array}{l}\text { - 현대무용, 발레, 즉흥춤 등 과목별 이론/실기 } \\
\text { 교육 추진 } \\
\text { - 공동창작 토론회 및 공연 }\end{array}$ & 61 & 4명 \\
\hline $\begin{array}{c}\text { 아시아-아프리카-중 } \\
\text { 남미 댄스 익스체인지 }\end{array}$ & 국제무용협회 & \begin{tabular}{|l|} 
- 한국 전통춤·현대무용 전문토론회 \\
- 한국 무용과 문화를 배운 뒤, 교육내용을 기 \\
반으로 공동창작 작품 발표
\end{tabular} & 79 & 5명 \\
\hline $\begin{array}{c}\text { 문화유산 전문가 초청 } \\
\text { 연수 }\end{array}$ & 한국문화재재단 & $\begin{array}{l}\text { - 문화유산 전문가 전문 이론강의 및 현장교육 } \\
\text { - 재단-동반자 공동 사업 수행 수행 및 개인 } \\
\text { 연구성과 도출 }\end{array}$ & 90 & 6 명 \\
\hline $\begin{array}{c}\text { 춤으로 소통하는 } \\
\text { 아시아 }\end{array}$ & $\begin{array}{l}\text { 세종대학교 } \\
\text { 산학협력단 } \\
\text { 다문화연구소 }\end{array}$ & $\begin{array}{l}\text { - 한국의 전통 문화예술의 현대적 창작 활용 } \\
\text { 사례들에 대한 자료, 경험 } \\
\text { - 다양한 국가 전통이 어우러진 창작 사업 개발 }\end{array}$ & 24 & 3명 \\
\hline $\begin{array}{l}\text { 이중 언어 베이스의 } \\
\text { 국제연극 교류 } \\
\text { 인재양성 } \\
\text { 프로그램 '개항' }\end{array}$ & $\begin{array}{l}\text { 배우공동체 } \\
\text { 자투리 }\end{array}$ & $\begin{array}{l}\text { - 공연 이중언어화 체험 및 조명 디자인 기초 } \\
\text { 연수 } \\
\text { - 이중언어연극 관련 네트워크 교류 }\end{array}$ & 61 & 4명 \\
\hline $\begin{array}{c}\text { 아태지역 } \\
\text { 무형문화유산 } \\
\text { 동반자 연수사업 }\end{array}$ & $\begin{array}{c}\text { 유네스코 } \\
\text { 아태무형문화센터 }\end{array}$ & $\begin{array}{l}\text { - 주제별 개별연구 수행 및 다양한 방식의 전 } \\
\text { 문연수를 통한 무형유산 보호 실무역량 강화 } \\
\text { - 국내 무형유산 유관기관 및 현장방문을 통한 } \\
\text { 전문성 강화 }\end{array}$ & 94 & 6명 \\
\hline $\begin{array}{c}2019 \text { 아시아 소리 } \\
\text { 프로젝트 }\end{array}$ & $\begin{array}{c}\text { 전주세계소리축제 } \\
\text { 조직위 }\end{array}$ & $\begin{array}{l}\text { - 아시아 전통음악가 } \\
\text { - 전주세계소리축제 초연 및 창작곡 작/편곡 } \\
\text { 작업 }\end{array}$ & 76 & 6명 \\
\hline
\end{tabular}




\begin{tabular}{|c|c|c|c|c|}
\hline 사업명 & 주관기관 & 주요 사업내용 & $\begin{array}{l}2019 \text { 예산 } \\
\text { (백만 원) }\end{array}$ & 인원 \\
\hline $\begin{array}{c}2019 \text { 문화동반자 高 } \\
\text { ON! }\end{array}$ & 충남문화재단 & $\begin{array}{l}\text { - 동반자들과의 협업을 통한 전통예술 공연 창 } \\
\text { 작 및 한국과 동반자국의 전통예술 상호 연 } \\
\text { 수 및 워크숍 추진 } \\
\text { - 충남의 무형문화재를 기반으로 한 공연 창작 } \\
\text { 을 통해 한국전통문화유산의 재해석 }\end{array}$ & 29 & 3명 \\
\hline $\begin{array}{l}\text { 탈춤 관련 예술인 } \\
\text { 초청 교육 }\end{array}$ & 안동축제관광재단 & $\begin{array}{l}\text { - 하회별신굿탈놀이 등 탈문화를 통한 문화교류 } \\
\text { - 안동국제탈춤축제 참가를 통한 문화동반자 } \\
\text { 역량 강화 및 지역 내 문화교류를 통한 문화 } \\
\text { 다양성 이해증진 }\end{array}$ & 58 & 4명 \\
\hline $\begin{array}{c}\text { 국가별 } \\
\text { 전통공연프로그램 } \\
\text { 공유확산 연수 } \\
\end{array}$ & 충북민예총 & $\begin{array}{l}\text { - 국가별 전통음악 연수 및 융합 사업 발굴 확산 } \\
\text { - 지식공유, 창작 토론회, 성과공유 및 발표 }\end{array}$ & 88 & 6명 \\
\hline $\begin{array}{l}\text { 문화동반자사업 } \\
\text { 사무국 운영 }\end{array}$ & & $\begin{array}{l}\text { - 운영기관 업무지원 } \\
\text { - 동반자 후속관리 및 지원 }\end{array}$ & 164 & \\
\hline 10 개 사업 & 10 개 기관 & & 824 & 47명 \\
\hline
\end{tabular}

〈표 3-11〉 문화동반자 소속기관사업 내역(2019)

\begin{tabular}{|c|c|c|c|c|}
\hline 사업명 & 주관기관 & 주요 사업내용 & $\begin{array}{c}2019 \text { 예산 } \\
\text { (백만 원) }\end{array}$ & 인원 \\
\hline $\begin{array}{c}\text { MMCA 국제펠로우십 } \\
\text { 연구 프로그램 }\end{array}$ & 국립현대미술관 & $\begin{array}{l}\text { - 한국현대미술 관련 개별 연구 실시 및 연구 } \\
\text { 결과 발표 } \\
\text { - 국내미술현장(기관, 작가 방문 및 인터뷰, 문 } \\
\text { 화탐방 등) 연수 }\end{array}$ & 46 & 3명 \\
\hline $\begin{array}{l}\text { 국외 박물관 } \\
\text { 전문인력 연수 }\end{array}$ & 국립민속박물관 & $\begin{array}{l}\text { - 베트남 박물관의 현지 관계자를 초청, 국립민 } \\
\text { 속박물관의 다양한 교육 사업 운영기법 체험 } \\
\text { 기회 제공 } \\
\text { - 박물관 교육의 기획·운영·성과관리 방법 등 } \\
\text { 전문 영역에 대한 경험을 통해 자국 박물관에 } \\
\text { 활용할 수 있도록 연수 기회 제공 }\end{array}$ & 14 & 1명 \\
\hline $\begin{array}{c}\text { 해외 사서 연수 } \\
\quad \text { 프로그램 }\end{array}$ & 국립중앙도서관 & $\begin{array}{l}\text { - 도서관 전문지식 및 선진기술 습득의 기회 제 } \\
\text { 공하여, 한국 관련 정보 능력 향상 } \\
\text { - 한국 관련 자료의 수집·정리, 능력 개발을 통 } \\
\text { 한 자국 거점 도서관 내 한국문화 전파 요원 } \\
\text { 양성 }\end{array}$ & 71 & 4명 \\
\hline $\begin{array}{l}\text { AMFEK } \\
\text { (Art Major Faculty } \\
\text { Explore K-Arts) }\end{array}$ & 한국예술종합학교 & $\begin{array}{l}\text { - 개발도상국 주요 예술대학 교·강사, 신진예술 } \\
\text { 가 등을 초청, 한예종 전문연수제공 및 결과 } \\
\text { 발표회 개최 } \\
\text { - 선진 예술교육 과정 경험 제공과 전공 교수법 } \\
\text { 전수를 통한 교사역량 강화 및 차세대 예술가 } \\
\text { 발굴·육성 지원 }\end{array}$ & 80 & 5명 \\
\hline 4개 사업 & 4개 기관 & & 211 & 13명 \\
\hline
\end{tabular}


(7) 유네스코 신탁기금

2019 2021년에는 아세안 지역의 문화창의 향상 정책지원을 위한 아세안 문화정책 담당자 정책 워크숍 및 인도네시아 문화적 표현의 다양성 정책 지원·태국 문화창의산업 정책 활성화를 위한 신탁기금 사업을 추진하였다.

\section{【유네스코 협력사업】}

(목적) 문화적 표현 다양성을 위한 창조산업개발 지원

(방식) 유네스코 신탁기금(Funds-in-Trust) 기금 출연

(근거) 유네스코 개도국 문화산업 지원을 위한 $\mathrm{MOU}(2006$ 체결, 2008 수정)

사업 현황

- (2007 2010) : 베트남 전통공예산업 발전, 몽골 문화원형 디지털화사업(3억)

- (2009 2013) : 카자흐스탄, 우즈베키스탄 전통공예 보존·발전(3억)

- (2011 2014) : 부르키나파소 문화산업 육성기관 설립지원, 라오스·몽골·베트남 창조산업 지속가능성 강화(5억)

- (2013 2018) : 몽골·베트남·우간다 문화창의산업 진흥정책·전략개발(5억)

- (2015 2019) : 우즈베키스탄·라오스·르완다 문화적 표현의 다양성을 위한 창조산업 발전(4.8억)

- (2017 2019) : 아-태지역 문화다양성 전문가 역량강화, 파키스탄·방글라데시 문화창의산업 개발역 량 강화(4.8억)

- (2019 ) : 아세안 문화정책 담당자 정책 워크숍, 인도네시아-태국 문화창의산업 강화(4.8억)

\section{나. 2020년 국제문화교류 사업}

\section{1) 전체 사업 현황}

코로나19로 직접 타격을 받은 2020년의 국제문화교류 사업의 현황을 살펴보면 총 67건으로서 추진 사업 건수로는 2019년에 비해 4건 증가한 수치이다. 문화산업, 예술, 전통문화 등의 분야를 중심으로 사업이 진행되었다. 수행기관은 총 20 개 기관이다. 2019년에 비해 2개 기관이 증가하였다. 기관별로 진행된 사업 건수는 다음과 같다. 세 종학당재단 5건, 한국문화예술위원회 7건, 국립중앙박물관 5건, 한국국제문화교류진흥 원 6건, 국립현대미술관 7건, 국제방송교류재단 4건, 저작권위원회 2건, 국립중앙도서 관 2건, 국립국악원 6건, 국립중앙극장 2건, 영화진흥위원회 2건, 한국전통공연예술진 흥재단 2건, 국립아시아문화전당 2건, 해외문화홍보원 4건, 한국출판문화산업진흥원 1 건, 예술경영지원센터 4건, 한국문화예술교육진흥원 1건, 콘텐츠진흥원 1 건, 한국공예 디자인문화진흥원 1건, 아시아문화원 1건 이다. 하지만, 2019년에 국제문화교류 사업이 있었던 기관 중 한국문화정보원, 한식진흥원, 한국문학번역원은 2020년 국제문화교류 사업이 하나도 진행되지 않았다. 2020년 국제문화교류 사업을 카테고리별로 분류해보 
면 영화상영/전시/전시실 설치 사업은 2건, 박람회 참가지원은 2건, 콘텐츠 제작지원은 1건, 네트워크 구축 및 동향조사사업은 2건, 외국/국내 축제참가 사업은 7건, 인력파견/ 초청사업은 12 건, 해외/국내공모사업은 0 건, 해외행사 참가/출판/초청 지원 사업은 4 건, 플랫폼 구축사업은 2건, 아카이브 $\mathrm{DB}$ 확산 사업은 0 건, 교류사업은 18 건, 레지던시 사업은 6 건, 교류센터 설치사업은 1 건, 지원사업은 10 건 이다.

〈표 3-12〉2020년 국제문화교류사업 분류

\begin{tabular}{|c|c|c|c|c|c|c|c|c|c|c|c|c|c|c|c|}
\hline & $\begin{array}{l}\text { 영화 } \\
\text { 상영 } \\
\text { / } \\
\text { 전시 } \\
\text { /전 } \\
\text { 시실 } \\
\text { 설치 }\end{array}$ & \begin{tabular}{|c} 
박람 \\
회 \\
참가 \\
지원
\end{tabular} & $\begin{array}{c}\text { 콘텐 } \\
\text { 츠 } \\
\text { 제작 } \\
\text { 지원 }\end{array}$ & $\begin{array}{c}\text { 네트 } \\
\text { 워크 } \\
\text { 구축 } \\
\text { 및 } \\
\text { 동향 } \\
\text { 조사 }\end{array}$ & $\begin{array}{l}\text { 외국 } \\
\text { / } \\
\text { 국내 } \\
\text { 축제 }\end{array}$ & $\begin{array}{c}\text { 인력 } \\
\text { 파견 } \\
\text { / } \\
\text { 초청 }\end{array}$ & $\begin{array}{c}\text { 해외 } \\
\text { / } \\
\text { 국내 } \\
\text { 공모 }\end{array}$ & $\begin{array}{c}\text { 해외 } \\
\text { 행사 } \\
\text { 참가/ } \\
\text { 출판/ } \\
\text { 초청전 } \\
\text { 시지원 }\end{array}$ & $\begin{array}{l}\text { 플랫 } \\
\text { 폼 } \\
\text { 구축 }\end{array}$ & $\begin{array}{l}\text { 아카 } \\
\text { 이브 } \\
\mathrm{DB} \\
\text { 확산 }\end{array}$ & $\begin{array}{l}\text { 교류 } \\
\text { 사업 }\end{array}$ & $\begin{array}{l}\text { 레지 } \\
\text { 던시 }\end{array}$ & $\begin{array}{l}\text { 교류 } \\
\text { 센터 } \\
\text { / } \\
\text { 기구 } \\
\text { 설치 }\end{array}$ & $\begin{array}{l}\text { 지원 } \\
\text { 사업 }\end{array}$ & $\begin{array}{l}\text { 합 } \\
\text { 계 }\end{array}$ \\
\hline 국립중앙박물관 & 2 & . & & 1 & & 1 & & 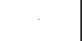 & . & & & . & & 1 & 5 \\
\hline $\begin{array}{c}\text { 한국공예디자인문화 } \\
\text { 진흥원 }\end{array}$ & & 2 & & & & . & & . & & & & & & & 2 \\
\hline 한국콘텐츠진흥원 & & . & 1 & & & . & & . & . & & & . & 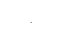 & & 1 \\
\hline $\begin{array}{c}\text { 한국문화예술교육 } \\
\text { 진흥원 }\end{array}$ & & & & & & & & & & & 1 & & & & 1 \\
\hline 한국문화예술위원회 & & . & 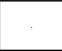 & 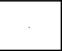 & . & 1 & & 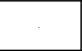 & 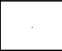 & 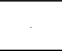 & 5 & 1 & & 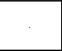 & 7 \\
\hline 한국문화정보원 & & . & & & & 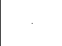 & & 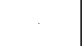 & . & & & . & & & 0 \\
\hline 예술경영지원센터 & & . & : & 1 & - & 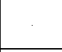 & . & 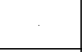 & 1 & & 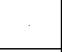 & 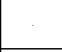 & & 3 & 5 \\
\hline 한식진흥원 & & . & & 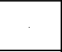 & & . & & . & 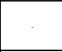 & & . & . & & 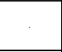 & 0 \\
\hline 국립중앙도서관 & & . & 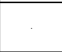 & 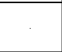 & . & 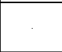 & & 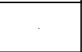 & 1 & 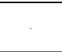 & 1 & 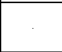 & & 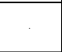 & 2 \\
\hline 국립현대미술관 & & . & 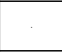 & 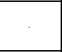 & . & 3 & & 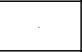 & 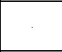 & 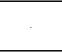 & 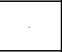 & 5 & & 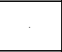 & 8 \\
\hline 국제방송교류재단 & . & 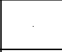 & 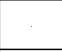 & 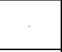 & . & 1 & 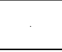 & 1 & . & 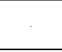 & 2 & 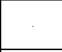 & . & . & 4 \\
\hline 세종학당재단 & & . & 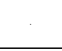 & . & . & 3 & . & 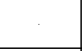 & 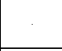 & . & 2 & 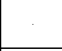 & & 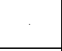 & 5 \\
\hline 아시아문화원 & & 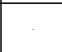 & & . & - & . & . & 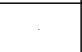 & 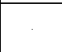 & & 1 & 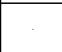 & & 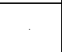 & 1 \\
\hline 영화진흥위원회 & & . & & . & 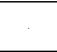 & 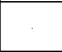 & . & 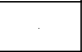 & 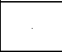 & & 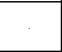 & 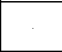 & 1 & 1 & 2 \\
\hline $\begin{array}{l}\text { 전통공연예술 } \\
\text { 진흥재단 }\end{array}$ & & & & & & & & & & & 1 & : & & 1 & 2 \\
\hline $\begin{array}{c}\text { 한국국제문화교류 } \\
\text { 진흥원 }\end{array}$ & & & . & & & 3 & & & 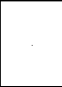 & 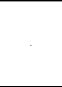 & & 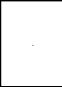 & & 2 & 5 \\
\hline 한국문학번역원 & & 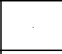 & & 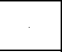 & 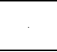 & 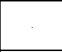 & 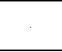 & 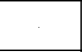 & . & & 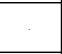 & . & & 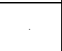 & 0 \\
\hline 국립아시아문화전당 & & . & . & 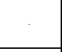 & & 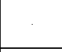 & 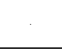 & 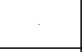 & 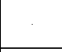 & . & 2 & 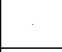 & & 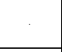 & 2 \\
\hline 한국저작권위원회 & & . & . & . & . & . & & . & . & . & 1 & . & & 1 & 2 \\
\hline 국립국악원 & . & . & 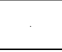 & . & 4 & - & & 1 & . & . & 1 & 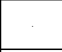 & & 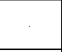 & 6 \\
\hline 국립중앙극장 & & . & 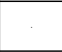 & . & . & 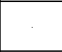 & & 2 & 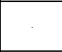 & 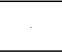 & 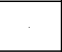 & 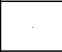 & & 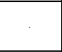 & 2 \\
\hline 해외문화홍보원 & & - & & & 3 & & & & & & 1 & & & . & 4 \\
\hline
\end{tabular}




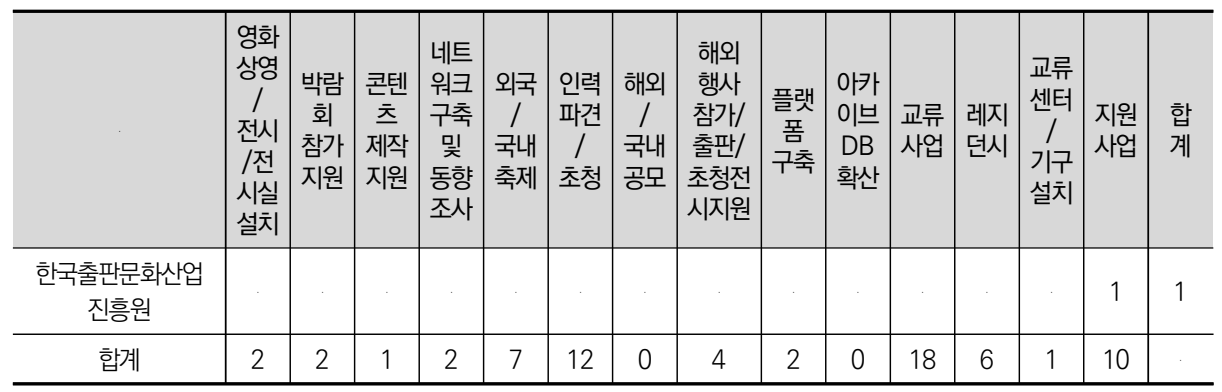

2020년 국제문화교류 사업이 전체적으로 2019년에 비해 사업이 완전히 중단되거나 하지 않고, 다양한 방식으로 계획된 사업들은 진행이 된 것으로 보인다. 하지만 앞서 살 펴본 대로 전체 예산 소요가 $30 \%$ 가량 줄어든 것을 고려했을 때, 사업은 규모가 축소되 거나 비대면 방식으로 전환되어 진행된 것으로 볼 수 있다. 다음의 주요사업 현황에서도 볼 수 있듯이 다양하게 비대면 방식을 활용하여 사업을 진행하였다. 공연을 녹화 후 송 출하거나, 미술 작품을 VR로 구현하여 전시를 진행하거나, 다양한 장르의 예술작품을 상호 교차 상영하는 등의 다양한 방식으로 사업을 추진했다.

\section{2) 주요사업 현황}

(1) 수교 계기 문화행사 개최

각국과의 수교 매 10 주년 되는 해를 기념하면서 이를 계기로 우리문화를 자연스럽게 알리고 이해와 신뢰를 높이는 문화교류 행사를 개최하는데 2020년에는 코로나19의 여파 로 대부분의 대면 문화행사가 취소 또는 연기되었고 일부 행사는 비대면으로 추진되었다.

$\bigcirc$ 한국-아랍에미리트(UAE) 상호 문화교류의 해

문화체육관광부가 주최하고 한국국제문화교류진흥원과 주아랍에미리트(UAE) 한국문 화원, 뉴욕대 아부다비 예술원(The Arts Center at New York University Abu Dhabi)이 공동 주관한 〈악단광칠〉 공연이 2020년 한국-아랍에미리트 수교 40주년을 기념하여 11 월 18 일 비대면(한국에서 녹화 후 송출하는 방식)으로 개최되었다. 한국-아 랍에미리트 상호 문화교류의 해를 기념하여 아랍에미리트(UAE) 한국문화원과 아부다비 '마나랏 알 사디야트 미술관(Manarat Al Saadiyat)'과의 협력을 통해 〈오감도 : 한국 미술의 다섯 풍경>가 비대면으로 전시되었다. '트래블링 코리안 아츠(Traveling 
Korean Arts)' 사업의 일환으로 2020년 '한국-아랍에미리트 상호 문화교류의 해'를 기 념하여 추진되었으며, 다양한 장르에서 활동하는 한국 예술가 14 명의 작품 57점을 가상 현실(VR)로 구현해 현지인 총 8천명이 관람하였다.

한국-러시아 상호 문화교류의 해

한국-러시아 수교 30주년을 기념하여 2020 2021년 2년간을 ‘한국-러시아 상호 문 화교류의 해'로 지정하였다. 우정과 신뢰로 함께 빚는 미래'라는 공식 슬로건 아래, 포괄 적 쌍방향 교류, 차세대 문화교류, 국민이 함께 하는 문화교류라는 3가지 핵심 전략을 중심으로 교류 사업을 추진했다.

〈표 3-13〉 비대면 한국-러시아 문화의 달 사업 총괄표(2020)

\begin{tabular}{|c|c|c|c|}
\hline 순서 & 사업명 & 기간 & 내용 \\
\hline 1 & $\begin{array}{c}\text { 한국-러시아 상호 } \\
\text { 문화교류의 해 기념공연 }\end{array}$ & 12월 1일 & $\begin{array}{c}\text { 한복드라마와 영상, 한복 패션쇼와 한복 퍼포먼스를 } \\
\text { 소재로 한 융복합 창작공연 }\end{array}$ \\
\hline 2 & 러시아 정원 & 12월 & $\begin{array}{l}\text { 강동문화센터 외부 공간 내 라이트 플라워 활용한 } \\
\text { '러시아 정원' 설치 및 러시아 발레 영상 상영 }\end{array}$ \\
\hline 3 & $\begin{array}{l}\text { 한국-러시아 } \\
\text { 문화교류 포럼 }\end{array}$ & 12월 4일 & $\begin{array}{c}\text { 수교 이후 } 30 \text { 년 간 양국의 문화교류 흐름 및 } \\
\text { 주요사례를 짚어보고 팬데믹 이후 문화교류 방향을 } \\
\text { 전망하는 포럼 개최 }\end{array}$ \\
\hline 4 & $\begin{array}{l}\text { 한국-러시아 음악 } \\
\text { 포커스 }\end{array}$ & $\begin{array}{l}\text { (한)12월 9일 11일 } \\
\text { (러) 12월 21일 23일 }\end{array}$ & $\begin{array}{c}\text { 온라인 플랫폼을 활용한 양국 우수 음악 작품 및 단체 } \\
\text { 소개 }\end{array}$ \\
\hline 5 & $\begin{array}{l}\text { 한국-러시아 영화 } \\
\text { 온라인 기획전 }\end{array}$ & 12월 15일 22일 & $\begin{array}{c}\text { 양국 영화(각 5편, 총10편) 온라인 } \\
\text { 기획상영회 개최 }\end{array}$ \\
\hline 6 & $\begin{array}{l}\text { 한국 어린이 } \\
\text { 그림책 포커스 }\end{array}$ & $\begin{array}{l}\text { 12월 16일 } \\
\text { ‘21년 1월 31일 }\end{array}$ & $\begin{array}{c}\text { 한국의 그림책 작가들과의 협업을 통해 러시아 어린이 } \\
\text { 대상 한국 그림책 작품을 영상 콘텐츠로 제작하여 } \\
\text { 온라인 소개 }\end{array}$ \\
\hline 7 & $\begin{array}{l}\text { 한국-러시아 } \\
\text { 현대무용 포커스 }\end{array}$ & $\begin{array}{l}\text { (한)12월 17일 19일 } \\
\text { (러)'21년 1월 } \\
\text { 17일 19일 }\end{array}$ & $\begin{array}{c}\text { 온라인 플랫폼을 활용한 양국 우수 현대무용작품 및 } \\
\text { 단체 소개 }\end{array}$ \\
\hline 8 & $\begin{array}{c}\text { 한국-러시아 } \\
\text { 청년 작가 교류전 }\end{array}$ & $\begin{array}{l}\text { 12월 18일 } \\
\text { 21년 3월 31일 }\end{array}$ & $\begin{array}{c}\text { '시간’이라는 공통된 주제 아래 양국에서 활발하게 } \\
\text { 활동하는 청년 작가 조명 } \\
\end{array}$ \\
\hline
\end{tabular}

- 한국-러시아 온라인 공연주간

한국-러시아 상호 문화교류의 해 사업의 일환으로 8월 11 일부터 14 일까지 4 일간 '한 국-러시아 온라인 공연주간을 운영하며, 양국의 음악, 무용, 서커스 등 다양한 장르의 예술작품을 교차 상영했다. 
- 한국-러시아 상호 문화교류의 해 공식인증 사업

2차례의 공모를 통해 민간과 지방자치단체가 추진하는 한국-러시아 간 전통문화, 공 연예술, 시각예술, 영상예술, 음악, 문학 및 출판, 패션, 체육, 관광, 학술 등 다양한 분야 의 문화교류사업을 '한국-러시아 상호 문화교류의 해 공식인증 사업' 으로 선정하였고, 공식인증사업으로 선정된 총 20 개 사업은 '한국-러시아 상호 문화교류의 해’ 의 슬로건 과 로고, 후원 명칭을 사용할 수 있는 권리를 부여받고, '한국-러시아 상호 문화교류의 해' 공식 채널을 통해서 홍보하였다.

- 한국-러시아 민간교류 지원사업

민간중심의 교류 활성화 및 협력 다각화를 위해 민간 우수예술 작품전시를 지원했다. 광주국제비엔날레는 한국을 대표하는 현대미술 작가 중 한 사람인 '이불'과 러시아 상트 페테르부르크 마네지 중앙전시관과 협력해 2020년 11월 11일부터 2021년 1월 31일까 지 러시아 현지에서 대규모 한국인 작가 전시인 〈Utopia Saved〉를 개최했다.

- 비대면 한국-러시아 문화의 달

전 세계적인 코로나19 확산 추세 지속 상황에 대응하기 위해 2020년 12월 한 달 동 안 온라인 플랫폼을 활용하여 한국-러시아 양국의 공연, 포럼, 음악, 영화, 무용, 문학, 신진예술가 교류 등 다양한 문화예술 분야를 조명하는 비대면 행사를 개최했다.

(2) 권역별·국가별 문화교류

한·중·일 문화장관회의 2020년에는 일본 기타큐슈에서 개최될 예정이었으나 코로나19 확진자 증가 추세에 따라 2021년으로 개최가 연기되었다.

동아시아문화도시 한·중·일 공동 추진 2020년 동아시아문화도시는 한국의 순천시, 일본 기타큐슈시, 중국 양저우시가 선정 되어 2019년 한·중·일 문화장관회의에서 발표되었으나, 코로나19 전세계적 확산으로 인하여 교류가 어려워짐에 따라 2021년까지 사업 기간을 1년 연기하는 것으로 2020년 7월 3국이 합의하였다. 한편 2019년 동아시아문화도시였던 인천시에서 후속사업으로써 2020 동아시아 합창제를 개최했는데, 2019년 동아시아 문화도시로 선정되었던 중국 시 
안과 일본 도시마구 합창단은 온라인 영상으로 참여하였다.

한일문화교류회의 운영

- 한일문화교류회의

한중일문화교류포럼은 2005년부터 한중일 3개국에서 매년 순차 개최하는데 2020년 에는 한중일 온라인 서예전을 개최하였다. 3국을 대표하는 서예 작가들의 코로나19 극 복과 우호 교류를 주제로 한 작품 200여 점을 3국의 일반 시민이 직접 인터넷으로 관람 할 수 있는 기회를 마련하였고 서울, 베이징, 교토에서 동시에 열린 온라인 개막식에서 는 초정 권창륜 서예가 등 3국을 대표하는 서예 작가가 '함께 힘을 합쳐 코로나19를 극 복하자'는 의미의 공동 휘호를 동시에 완성하는 세레모니 개최하였다.

$\bigcirc$ 한-아세안 문화장관회의·아세안 +3 (한·중·일) 문화장관회의 및 한-아세안 문화혁 신 포럼

한·중·일 3국과 아세안의 문화협력 관계 증진을 위하여 2년마다 열리는 '아세안+3 문화장관회의' 와 '한-아세안 문화장관회의'는 당초 캄보디아 프놈펜에서 개최될 예정이 었으나, 코로나19 확산에 따라 10월 22일 비대면 화상회의 방식으로 진행되었다. 한편 2020 한-아세안 문화혁신포럼은 10 월 21일부터 22일까지 비대면으로 개최되었다.

주요 20개국(G20) 문화장관 화상회의

코로나19 이후 문화 분야 혁신.발전을 위한 국제협력 방안을 모색하기 위한 '주요 20 개국(G20) 문화장관회의(공동의장국 사우디아라비아이탈리아)'가 11 월 4일 비대면으로 개최되었다.

$\bigcirc$ 한-유럽연합(EU) 문화협력위원회

한-유럽연합(EU) 문화협력위원회는 유럽연합(EU)이 있는 벨기에에서 열릴 계획이었 으나, 코로나 상황을 고려해 비대면 화상회의 방식으로 개최되었다.

우수프로그램 권역별 순회 지원 "트래블링 코리안 아츠"

2020년에는 코로나19 확산으로 공연과 전시 프로그램이 온라인으로 진행되었다. 크 로스오버 창작국악팀 〈블랙스트링〉의 미국 4개 도시 순회, 현대무용팀 아트프로젝트 보 라의 〈소무〉 아르헨티나칠레 온라인 공연. 2020년 부에노스아이레스 현대무용제 일환 으로 이루어진 아르헨티나 〈소무〉 공연은 온라인 공연과 현지 무용수들이 온라인으로 
교류하는 프로그램으로 진행하였다. 전시 사업도 코로나19 영향으로 총 8개국에서 보내 온 작품을 온라인 가상현실(VR) 기술 등을 활용하여 온라인 전시하였다. 2020년은 전시 분야를 진행했는데, 총 8 개국 16 명의 전시기획자와 행정직원이 참여하였으며, 당초 1 주 이던 기간을 3 주로 늘려 한국 시각예술 소개 강의 외에도 프로그램 풀 전시를 소개하는 E-book 및 영상 별도 제작, 화상회의를 통해 해외 참가자들과 국내 프로그램 풀 내 전 시기획자들 간 개별 실시간 회의를 진행하였다.

(3) 국제문화교류 유관기관 간 협력 '국제문화교류 협의체' 운영

10월 28일부터 29일까지 4개국(호주, 벨기에, 카자흐스탄, 남아프리카공화국) 주한 외교단과 국내 유관기관이 참여하는 '2021-2022년 수교계기 기념 국가 실무협의회'를 개최했다. 4 개국의 주한외교단은 각 국가의 주요 국제문화교류 사업과 관심사업 유형 등에 대해 발표하고, 참석한 국내 기관들은 협력 방안을 제시하며, 상호 정보 공유와 비 대면 사업 추진과 같은 포스트코로나 시대의 새로운 협력 방안들을 논의하였다. 국제문 화교류협의체 비대면 합동회의는 12 월 10 일 협의체 소속 국내기관 담당자 및 주한외교 단 등 총 35 개 기관 68 명 참여하였다. 이 회의에서 문화체육관광부의 「국제문화교류 진 흥 종합계획('18 22)」개정안을 발표하여 포스트코로나 시대를 대비한 국제문화교류 정 책의 방향을 제시하였다.

(4) 민간협업 문화교류

지역의 국제문화교류 역량을 강화함으로써 국제 교류 기반 확대를 지원하는 사업으로 2020년에는 경기 김포시(김포문화재단)의 '한강 프리존, 강을 잃어버린 도시展'과 전남 해남군(시화풍정 담소)의 '평화의 시마을 해남' 등 8개 사업이 '2020 국제교류사업 추진 지원' 공모를 통해 선정되어 미국, 인도, 이탈리아 등 5 개국 8 개 도시와 지역문화를 매개 로 비대면 교류를 추진했다.

(5) 문화동반자 사업

2020년 문화동반자 사업은 코로나19 상황으로 최초로 온라인 연수로 추진되었으며, 문화전문가(개도국 문화예술 전문가)와 문화행정가(현지 문화부 공무원)로 세분화하여 
대상별 맞춤형 교육 및 문화사업 컨설팅을 제공하고, 연수생들이 현지 사업화를 추진 할 수 있도록 지원했다.

(6) 유네스코 신탁기금

2020년부터는 아세안 지역의 문화창의 향상 정책지원을 위한 아세안 문화정책 담당 자 역량 강화 교육 및 인도네시아 문화적 표현의 다양성 정책 지원, 태국 문화창의산업 정책 활성화, 중앙아시아 4 개국(카자흐스탄, 키르기스스탄, 타지키스탄, 우즈베키스탄) 문화창의산업 발전을 위한 신탁기금 사업을 추진했다.

\section{라. 2021년 국제문화교류 사업 현황}

다음은 국제문화교류 종합정보시스템 '문화로'에 집계되어 있는 2021년 국제문화교 류 사업현황이다. 2020년에 비해서 많은 기관들이 국제문화교류사업이 편성되지 않았 고, 전체적인 국제문화교류 사업건수도 많이 줄었다. 2019년과 2020년 국제문화교류 사업을 진행했던 기관들 중에서 한국문화예술교육진흥원, 한국문화정보원, 국립중앙도 서관, 국제방송교류재단, 아시아문화원, 한국문학번역원, 국립아시아문화전당, 한국저작 권위원회, 국립국악원, 국립중양극장, 해외문화홍보원, 한국출판문화산업진흥원 12 개 기관은 2021년 국제문화교류사업이 편성되지 않았다.

다음은 2021년 국제문화교류 사업을 기관별로 유형별 사업을 분류해보았다. 우선, 유 형별로 살펴보면, 전체적으로 지원사업이 16 건으로 가장 많이 계획되어있다. 그리고 인 력파견/초청 유형이 6건으로 두 번째로 많다. 나머지는 1 2건으로 계획되고 있다. 기관 별로는 17 건으로 한국콘텐츠진흥원이 가장 많은 사업을 계획하고 있다. 나머지 기관들 은 1 3건으로 하향 평준화 되었다. 콘텐츠 진흥원은 이스포츠, 방송영상, 음악 등 온라 인으로 진행가능한 아이템들이 중심으로 계획된 것으로 보인다. 다른 기관들은 매우 적 은 사업규모를 유지하거나 국제문화교류사업이 없어졌는데, 콘텐츠 진흥원의 국제문화 교류 사업이 절대적으로 늘어난 것은 사전에 예산 배정 등에 있어 조율이 된 것으로 판 단된다. 
〈표 3-14〉2021년 국제문화교류사업 분류

\begin{tabular}{|c|c|c|c|c|c|c|c|c|c|c|c|c|c|c|c|}
\hline & \begin{tabular}{|c|} 
영화 \\
상영/ \\
전시/ \\
전시 \\
실 \\
설치 \\
\end{tabular} & $\begin{array}{l}\text { 박람 } \\
\text { 회참 } \\
\text { 가지 } \\
\text { 원 }\end{array}$ & \begin{tabular}{|l} 
콘텐 \\
츠 \\
제작 \\
지원
\end{tabular} & \begin{tabular}{c|} 
네트 \\
워크 \\
구축 \\
및 \\
동향 \\
조사 \\
\end{tabular} & $\begin{array}{c}\text { 외국/ } \\
\text { 국내 } \\
\text { 축제 }\end{array}$ & \begin{tabular}{|c|} 
인력 \\
파견/ \\
초청
\end{tabular} & $\begin{array}{c}\text { 해외/ } \\
\text { 국내 } \\
\text { 공모 }\end{array}$ & \begin{tabular}{|c|} 
해외행 \\
사 \\
참가/ \\
출판/ \\
초청전 \\
시지원
\end{tabular} & $\begin{array}{l}\text { 플랫 } \\
\text { 폼 } \\
\text { 구축 }\end{array}$ & $\begin{array}{c}\text { 아카 } \\
\text { 이브 } \\
\mathrm{DB} \\
\text { 확산 }\end{array}$ & \begin{tabular}{|l|} 
교류 \\
사업
\end{tabular} & $\begin{array}{l}\text { 레지 } \\
\text { 던시 }\end{array}$ & \begin{tabular}{|c|} 
교류 \\
센터/ \\
기구 \\
설치
\end{tabular} & $\begin{array}{l}\text { 지원 } \\
\text { 사업 }\end{array}$ & 합계 \\
\hline $\begin{array}{l}\text { 국립중앙 } \\
\text { 박물관 }\end{array}$ & & & & & & & & 2 & & & & & & 1 & 3 \\
\hline $\begin{array}{l}\text { 한국공예디자 } \\
\text { 인문화진흥원 }\end{array}$ & & 1 & & & & 1 & & & & & & & & & 2 \\
\hline $\begin{array}{c}\text { 한국콘텐츠 } \\
\text { 진흥원 }\end{array}$ & & & & 1 & 1 & 1 & 1 & 1 & & & & & 2 & 10 & 17 \\
\hline $\begin{array}{c}\text { 한국문화예술 } \\
\text { 위원회 }\end{array}$ & & & & & & & & & & & 1 & & & & 2 \\
\hline $\begin{array}{c}\text { 예술경영지원 } \\
\text { 센터 }\end{array}$ & & & & & & & 1 & & & & 1 & & & 1 & 3 \\
\hline 한식진흥원 & . & & & & & 1 & & & & & & & & 1 & 2 \\
\hline 국립현대미술관 & . & & & & & . & & & & & & 1 & & 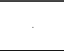 & 1 \\
\hline 세종학당재단 & . & & & & & 1 & & & & & & 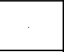 & & . & 1 \\
\hline 영화진흥위원회 & 1 & & & & & 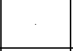 & & & & & & & & 1 & 2 \\
\hline $\begin{array}{c}\text { 전통공연예술 } \\
\text { 진흥재단 }\end{array}$ & & & 1 & & & & & & & & & & & 2 & 3 \\
\hline $\begin{array}{l}\text { 한국국제문화 } \\
\text { 교류진흥원 }\end{array}$ & & & 1 & & & 2 & & & & & & & & & 3 \\
\hline 합계 & 1 & 1 & 2 & 1 & 1 & 6 & 2 & 3 & 0 & 0 & 2 & 1 & 2 & 16 & \\
\hline
\end{tabular}

다음은 2021년 초 문화체육관광부 국제문화과에서 파악하고 있는 문화체육관광부 부 서별 국제문화교류 사업 계획의 내용이다. 국어정책과 2건, 전통문화과 3건, 국제문화과 30 건, 예술정책과 2건, 공연전통예술과 15 건, 시각예술디자인과 2건, 문화예술교육과 4건, 문화기반과 3건, 도서관정책기획단 1건, 종무1담당관 6건, 종무2담당관 2건, 문화 산업정책과 1 건, 한류지원협력과 10건, 문화통상협력과 6건, 방송영상광고과 4건, 출판 인쇄독서진흥과 8건 이다. 총 전체 사업건수가 99건이다. 진행방식이 3월 현재까지 미 정인 사업이 38 건이다. 전체 사업 중 $38 \%$ 가 아직까지 진행방식이 결정되지 않았다. 대 면과 비대면방식을 모두 고려하고 있는 사업이 14 건이 있고, 비대면방식으로 진행할 예 정인 사업이 17 건이다. 대면방식 진행 사업은 28 건이다. 
〈표 3-15〉2021년 문화체육관광부 부서별 국제교류사업 계획

\begin{tabular}{c|c|c|c|c|c}
\hline & 미정 & 비대면 & 대면 & 비대면/대면 & 합계 \\
\hline 건수 & 38 & 17 & 28 & 14 & 99 \\
\hline
\end{tabular}

전세계적으로 백신 보급이 이루어지고 있지만, 코로나19 상황이 어떻게 변할지 모르 는 상황에서 국제문화교류 사업을 안정적으로 진행하기는 아직까지 힘든 상황이다. 진행 방식이 아직 미정인 사업이 가장 많은 것이 이를 단적으로 보여준다. 비대면방식이 17 건, 비대면과 대면방식을 모두 고려하고 있는 사업이 14 건으로 코로나 시대에 비대면 방식의 교류사업은 계속 증가할 것으로 보인다. 따라서 비대면 방식의 교류사업이 좀 더 알차고 기존의 비대면 방식의 문제점을 보완하는 지속적으로 새로운 방안을 찾는 것 이 필요한 상황이다.

\section{3. 주요기관별 사업현황과 계획}

코로나19 상황이 지속되는 속에서 대면 자문을 구하기 힘든 상황에서 국제문화교류 사업을 진행하는 주요 기관들의 담당부서 책임자 분들과 담당자 분들께 서면자문을 요 청하였다. 서면자문 내용과 자료조사 결과를 바탕으로 기관별 코로나 대응 및 향후 사업 계획 등에 대한 내용을 정리한다. 코로나 대응을 어떻게 하였고, 디지털 기술관련 사업 은 어떻게 진행하고 있는지 정리하였다. 향후 코로나 대응에 따른 국제문화교류 후속 사업과 디지털 기술 활용한 사업 방안을 모색하는데 참조자료로 활용할 수 있다. 일부 기관들은 서면 자문 없이 자료조사 결과에 기반하여 정리하였다.

〈표 3-16〉 기관별 국제문화교류사업

\begin{tabular}{c|l}
\hline 기관명 & \multicolumn{1}{c}{ 국제문화교류사업 } \\
\hline 국립국악원 & 외국인용 온라인 콘텐츠 개발 중장기 계획 추친 \\
\hline 국립민속박물관 & $\begin{array}{l}\text { 국외 박물관, 한국 문화원 등과의 교류 사업, 온라인 일본 순회전시, 베트남 국립민족학박 } \\
\text { 물관 한국실 설치 준비, 한국민속문화상자 국외 보급사업 }\end{array}$ \\
\hline 국립중앙도서관 & $\begin{array}{l}\text { 해외 도서관계와의 교류협력사업, 해외 한국문화원 및 한국자료실 운영지원, 해외 사서와 } \\
\text { 의 인적 네트워크 활성화, 국제 자료 교환 사업 }\end{array}$ \\
\hline 국립중앙박물관 & 아시아 주요기관과 공동 연구, 소장품 상호대여 및 인력교류 등 국제 네트워크 사업 \\
\hline
\end{tabular}




\begin{tabular}{|c|c|}
\hline 기관명 & 국제문화교류사업 \\
\hline 국립현대미술관 & $\begin{array}{l}\text { 국제 레지던시 프로그램, 아티스트 레지던시 교환, MMCA International Research } \\
\text { Fellowship, International Artist Fellowship, International Exchange Residency, } \\
\text { International Artist/Researcher Residency Program, Mondriaan Fond } \\
\text { Fellowship Program }\end{array}$ \\
\hline 세종학당재단 & $\begin{array}{l}\text { 문화인턴교원 해외 파견, 세종학당 운영 및 지원, 세종학당 한국어 교원 국외 파견, 세종 } \\
\text { 문화아카데미, 세종학당 집현전 한국어교실, 온라인 세종학당 운영, 세종학당 우수학습자 } \\
\text { 초청 연수 사업 }\end{array}$ \\
\hline 아시아문화원 & $\begin{array}{l}\text { 아시아 } 6 \text { 개국 협력기관(일본 날리지 캐피탈, 태국 창조경제원, 홍콩 사이버포트, 중국 날 } \\
\text { 리지시티, 태국 국가혁신기구, 대만 디자인연구소 등) 들과 공동으로 ACIC(Asia } \\
\text { Creative \& Innovation Channel, 아시아 창조혁신채널)을 구축하여 온라인 콘텐츠 송 } \\
\text { 출, 비대면 교구재 제작 및 온/오프라인 동시 보급 }\end{array}$ \\
\hline 영화진흥위원회 & $\begin{array}{l}\text { 국제영화제참가활동지원, 외국영상물로케이션 인센티브, 한국영화 해외배급 선재물 제작 } \\
\text { 지원, 필름마켓 참가지원, 국제영화제 육성지원사업, 해외 장비전시회 참가지원 사업 }\end{array}$ \\
\hline 예술경영지원센터 & $\begin{array}{l}\text { 공연예술 해외진출지원, 전통예술 해외 아트마켓 및 진출지원, 공연예술 해외진출기반마 } \\
\text { 련, 서울국제공연예술제, 창작 뮤지컬 해외진출, 한국미술 글로벌 플랫폼 운영, 한국미술 } \\
\text { 해외출판지원, 미술품해외시장 개척지원 }\end{array}$ \\
\hline 한국콘텐츠진흥원 & $\begin{array}{l}\text { 방송영상콘텐츠 포맷 제작지원사업, K-POP 해외 쇼케이스 개최 지원, 한국패션문화 해 } \\
\text { 외진출 지원, 애니메이션 해외 전시마켓 참가 지원, 가상현실(VR)콘텐츠 사업화 지원, 캐 } \\
\text { 릭터 해외진출 지원, 신흥시장 개척 지원, 아시아 애니메이션 공동마켓 활성화 지원 }\end{array}$ \\
\hline $\begin{array}{l}\text { 한국국제문화교류 } \\
\quad \text { 진흥원 }\end{array}$ & $\begin{array}{l}\text { 국제문화교류협업 지원 및 인력양성, 국가간 문화교류 환경조성, 민간-지역 국제문화교류 } \\
\text { 사업지원, 국제문화교류 조사·연구, 한류페스티벌 개최 및 마케팅 지원, 한류 커뮤니티 } \\
\text { 활성화, 문화분야 국제협력 사업 }\end{array}$ \\
\hline $\begin{array}{l}\text { 한국공예디자인문화 } \\
\quad \text { 진흥원 }\end{array}$ & $\begin{array}{l}\text { 한복산업 활성화 관련 해외교류, 전통문화 해외거점 조성, 공예관광산업 육성을 위한 국제 } \\
\text { 교류 및 해외 박람회 참가지원, 공공디자인 진흥 관련 국제 타이포그래피 비엔나레 사업 }\end{array}$ \\
\hline $\begin{array}{l}\text { 한국문화예술교육 } \\
\text { 진흥원 }\end{array}$ & $\begin{array}{l}\text { 문화예술교육 ODA, 글로벌문화예술교육탐방프로젝트'A-round', 온.오프라인 국제교류 } \\
\text { 네트워크 구축사업 }\end{array}$ \\
\hline 한국문화예술위원회 & $\begin{array}{l}\text { 한국예술국제교류지원, 예술가해외레지던스지원, } \mathrm{ARKO} \text { 국제예술확산지원, 청년예술가해 } \\
\text { 외진출지원, 남북문화예술교류지원, 국제예술공동기금사업, 베니스비엔날레 한국관운영, } \\
\text { 해외문화기관교류사업 }\end{array}$ \\
\hline 문화재청 & $\begin{array}{l}\text { 국제문화재보존복구연구센터와 협력사업, 아세안 문화유산 협력기구 신설 추진, 해외 문 } \\
\text { 화유산 보수·복원 및 기술 지원 확대, 문화유산 보존역량 강화 지원 시설 장비 등 하드웨 } \\
\text { 어와 매뉴얼 기술 등 소프트웨어 지원, 전통문화 교육 연수 지원사업, 개발도상국 문화유 } \\
\text { 산 보존 관리, 활용 인력 전문성 강화 사업, 한국 문화재 홍보, 국외소재 한국 문화재 보 } \\
\text { 존관리 지원 }\end{array}$ \\
\hline 한국국제교류재단 & $\begin{array}{l}\text { 해외박물관 협력사업, 한국미술 큐레이터직 설치, 해외 한국문화행사 지원, 한국미술 전 } \\
\text { 문가 육성, 재외공관-KF 협력사업, 재외공관 한국영화상영지원 사업 }\end{array}$ \\
\hline 한국국제협력단 & $\begin{array}{l}\text { 자금-시설 및 기술 지원 등이 결합된 국제개발협력 사업, 개발컨설팅 사업, 연수 사업, } \\
\text { 전문 인력 파견 사업, 해외봉사단 파견 사업, 재난구호 등 인도적 지원 사업, 국내외 민간 } \\
\text { 단체와의 협력사업, 외국의 원조기관 및 국제기구와의 협력, 국제개발협력에 관한 이념 } \\
\text { 및 정책의 수립 등을 위한 조사·연구 }\end{array}$ \\
\hline 한식진흥원 & $\begin{array}{l}\text { 한식 아카이브 } \mathrm{DB} \text { 확산, 한식 전문강사 해외 교육기관 파견지원, 해외 호텔연계 한식인력 } \\
\text { 해외진출 지원, 해외한식당협의체 개별사업 지원, 국내 한식문화 축제 공동 개최 사업, } \\
\text { 해외교류단체 지원 사업 }\end{array}$ \\
\hline
\end{tabular}




\section{가. 문화체육관광부 소속 기관}

\section{1) 국립국악원}

국립국악원은 코로나 상황에 대응하기 위해 2020년 5월 14일 코로나 대응 정책 마련 을 위한 '온라인 생중계 긴급 토론' 실시하였다. 이후 무관중 및 비대면 공연 온라인 공 연 생중계 및 유튜브 송출(총 103회, 민속 3회, 남도 15회, 부산 4회) 사업을 확대하였 다. 민간 예술인 활동지원 온라인 공연프로그램 기획·제작하였다. 신규공연 기획(일일국 악 21회 295,239조회 / 사랑방중계 5회 25,759조회 / 희망 ON콘서트 31회 161,712 조회 / Gugak in (人) 30회 86,622조회) 등을 진행하였다. e-국악아카데미 활성화, 유 튜브 국악박물관 상설전시 해설 및 소개 등을 통해 2020년 위기 대응을 해나갔다. 또, 코로나로 인해 힘들어진 민간예술인 활동 지원을 위한 온라인 프로그램 기획과 제작했 다. 이러한 경험을 기반으로 2021년에는 ‘언택트 시대 고품질 국악 콘텐츠 보급 확대’를 목표로, 온라인 콘텐츠 개발 중장기 계획 추친(교육:교원, 어린이, 공연, 외국인용), 온라 인 콘텐츠 제작 및 보급, 뉴미디어 홍보 콘텐츠 개발 및 서비스, 기념 자료 전시 및 학술 회의 온오프라인 동시 진행을 계획하고 있다. 국립국악원은 이를 위해 예산 항목에도 반영하여 앞으로 더 많은 공연과 전시 콘텐츠를 온라인화하고, 유튜브 채널을 통한 상시 시청이 가능해질 것으로 보인다. 106)

\section{2) 국립민속박물관}

국립민속박물관은 국제교류부문에서는 국외 박물관, 한국 문화원 등과의 교류 사업이 진행되었다. 온라인으로 '미역과 콘부-바다가 잇는 한일 일상' 일본 순회전시(3.17. 5.17./온라인)가 개최되었다. 두 번째, 베트남 국립민족학박물관 한국실 설치 준비사업 이 지속되었다. 전시기획안 수립, 한국실 설치 전시 협약서 수정 체결(12월)등이 진행되 었다. 다음으로, 한국민속문화상자 국외 보급사업이 진행되었다. 대륙별 거점 한국문화 원 중심, 현지 주요 행사와 연계한 한국 민속문화 소개 교구재 상자를 제작·배포(전시·체 험 상자, 실물자료, 학습자료 세트 구성) 하였다.

106) 국립국악원 2021년 주요업무계획 발췌 
2020년 코로나 상황 속에서 온라인 민속문화 서비스 확대를 통한 복합문화공간으로 서의 역할 강화를 위한 노력을 전개하였다. 교육부분에서는 연령별(어린이·청소년·성 인), 특성별(전문가·외국인·소외계층)에 따른 맞춤형 교육 41종 457회 14,028명 참여 (대면 20종, 비대면 21종), 온라인 교육콘텐츠, 교보재 97편(종) 개발·보급 등의 사업이 이루어졌고, 공연부분에서는 우리민속한마당(매주 금·토), 문화가 있는 날, 계기 특별공 연 등 31회 (대면 7회, 비대면 24회)가 진행되었다. 행사부분에서는 입춘·설·대보름(대 면), 단오·추석·동지(비대면) 등 세시풍속행사에 36,501명 참여하였다. 가상공간 기반 온라인 전시, 어린이와 성인, 전문가와 외국인 및 소외계층에 맞춘 온라인 교육 콘텐츠 개발 및 보급107), 비대면 학술대회 등을 실시하며 코로나19 대응하였다.

2021년에는 코로나19와 같은 전염병 주제 전시회 뿐 아니라 대면·비대면이 모두 가능 한 전시, 실감형 전시기법 구현으로 직접 참여 가능한 전시를 기획하고, 비대면 채널을 운영하여 박물관 전 사업을 보급하려고 하고 있다. 또, 온라인 교육을 좀 더 확대하여 학교 가정에서 사용할 수 있는 교육 콘텐츠 개발 보급도 강화하기로 하였다. 국제교류사업 도 코로나 상황을 대비한 속에서 해외 전시 및 한국실 설치·운영, 외국인 대상 한국 전통문 화 체험 교육 개발·운영, 해외 박물관과의 문화교류 사업 등을 지속할 예정이다.108)

\section{3) 국립중앙도서관}

국립중앙도서관은 도서관 디지털 서비스 지능화 사업으로 국가 디지털 장서 확충, 이 용자 친화적 디지털 서비스 구현, 디지털 서비스 국내외 공유협력 사업 등을 지속해오고 있었다. 국제교류 사업으로는 해외 도서관계와의 교류협력사업, 해외 한국문화원 및 한 국자료실 운영지원, 해외 사서와의 인적 네트워크 활성화, 국제 자료 교환 사업 등을 추 진해오고 있다.

코로나 상황으로 인하여 어려움이 발생한 국제교류 사업은 해외 국립도서관과 업무교 류 및 직무 파견, 문화동반자 연수프로그램 운영, 해외 한국자료실 신규 설치에 따른 개 소식 참여 등이며, 국제회의 참여 및 업무협의도 할 수 없게 되었다. 온라인으로 대체할 수 있는 업무 즉, 업무 교류 중 주제 발표 및 회의, $\mathrm{MOU}$ 체결, 국제회의 등은 비대면으

107) 문화뉴스. 2020.10.6. “국립민속박물관, 초등학생 대상교과 연계 온라인 콘텐츠 제공”; 웰페어뉴스. 2020.7.9. “국립민속박물관, 장애인과 노인 맞춤형 온라인 콘텐츠 제공"

108) 국립민속박물관 2021년 주요 업무계획 발췌 
로 변경하여 참여 및 개최를 추진하였다.109)

2021년에는 자료 디지털화 강화, 도서관 일부 활동(저자와의 대화, 북튜버 양성과정 등)을 온라인화하고, 해외 교류 사업을 온라인 전환을 계획하였다. VR을 접목한 차별화 된 콘텐츠를 개발하여, 대상별 맞춤형 견학 VR 프로그램 개발도 추진하면서 최신 디지 털 기술을 활용한 사업도 지속적으로 확대하고 있다. 국제교류사업인 '해외 한국자료실 설치 운영(Window on Korea)', '해외 한국학 사서 워크솝', '해외 국립도서관과의 업 무교류 및 양해각서 체결', '국제 자료교류 사업'을 꾸준히 추진 중에 있으며 일부 온라 인으로 전환하여 추진하고 있다.

\section{4) 국립중앙박물관}

국립중앙박물관의 국제교류사업은 소속 관들의 특화 브랜드를 주제로 아시아 주요기 관과 공동 연구, 소장품 상호대여 및 인력교류 등 국제 네트워크를 선도하도록 지원하는 사업을 중심으로 이루어진다. 예를 들어, 국립광주박물관은 '아시아 도자 실크로드의 거 점' 브랜드화해서 동아시아지역 도자 네트워크 구축, 향후 도자 실크로드의 종점인 유럽 까지 확대, 중국, 일본, 태국, 베트남 등 주요 박물관과 학술지 발간, 공동조사(베), 특별 전 개최(중), 인적 교류(일), 동남아 도자 아카이브 구축 등의 사업을 진행한다.

국립중앙박물관은 디지털 기술을 활용한 신규사업 추진을 적극적으로 진행해왔다. 2019년부터 '국립 디지털 스마트 박물관' 도약 원년으로 하고, 비전 및 전략 수립을 진 행하고, 관련 $\mathrm{TF}$ 등을 구성하여 관련 사업을 꾸준히 진행해왔다. 실감형 디지털 콘텐츠 체험관을 4개소 조성하고, 문화유산 VR 콘텐츠 제작 및 $\mathrm{DB}$ 구축사업을 2019년부터 시작했다. 2021년에는 이 같은 경험을 확장할 계획이다. 빅데이터와 온라인 교육공간을 활용한 생애주기형 교육과 원격교육 제공, 온라인 교육 패키지 개발 및 배포, 문화재 정 보화 구축, $\mathrm{AI}, \mathrm{AR}, \mathrm{IOT}, 5 \mathrm{G}$ 기술과 스마트 박물관 조성110) 등 데이터화에 적극적인 모습을 보여주고 있다. ${ }^{111)}$

109) 서면자문 이현주 국립중앙도서관 국제교류홍보팀장 자문 내용 발췌

110) 뉴시스. 2021.5.21. “국립중앙박물관, 최첨단 전시 눈길...3D 모션 캡처 영상체험."

111) 국립중앙박물관 2019,2020,2021 업무계획 중 발췌 


\section{5) 국립현대미술관}

국립현대미술관은 국제문화교류사업으로서 국제 레지던시 프로그램, 아티스트 레지던 시 교환, MMCA International Research Fellowship, International Artist Fellowship, International Exchange Residency, International Artist/Researcher Residency Program, Mondriaan Fond Fellowship Program 등의 사업들이 있다. MMCA Internatioanl Research Fellowship은 2020년 연수자 선발 완료 후 2021년 7월 입국 하여 프로그램을 운영하고 있다. Mondriaan Fond Fellowship Program의 경우 2020 년 선발 작가가 2021년 8월에 입주 예정이다. 비대면으로 진행된 경우는 1건이며, 나머지 선발된 작가 및 연구자들은 2022년으로 입주 일정을 연기한 상태이다. 외국인 초청 사업의 경우 자가 격리 규정과 대면 행사 금지 등으로 진행에 어려움이 있었고, 향후 사업은 코로나 종식 시까지 대부분 취소되거나 비대면으로 전환되었다. 2020년에는 인적 교류 사업(연수 프로그램, 레지던시 사업 등) 대부분 사업 중단 및 연기, 학술 행사 등 공공 프로그램 사업 취소, 해외 작가 참여 전시의 경우 작품만 운송하는 방식으로 변경, 교육 프로그램 비대면 전환 운영 등으로 대응하였고, 2021년에는 인적 교류 사업 운영(자가격리 진행) 및 재연기, 학술 행사 등 공공 프로그램 비대면 전환 운영, 해외 작가 참여 전시의 경우 작품만 운송, 교육 프로그램 비대면 전환 운영 등의 방식으로 사업이 진행되었다.112)

코로나 대응을 위해 국립현대미술관은 비대면 관람 지원 서비스 제공, 디지털 미술관 개편(VR 작품온라인 작품 감상 등)113) 등의 사업변화를 추구하고, 2021년에는 디지털 관람 지원(큐레이팅 관람), 온라인 비대면 교육 다각화와 온라인 공연·전시, 온라인 홍보 플랫폼을 강화한다고 밝혔다.

\section{6) 세종학당재단}

세종학당재단의 국제교류사업은 문화인턴교원 해외 파견, 세종학당 운영 및 지원, 세 종학당 한국어 교원 국외 파견, 세종문화아카데미, 세종학당 집현전 한국어교실, 온라인 세종학당 운영, 세종학당 우수학습자 초청 연수 사업 등이 있다. 세종학당재단은 코로나 19 로 인하여 사업진행이 어려워지면서 2020년부터 모든 대면사업은 비대면사업을 우선

112) 2021.07. 국립현대미술관 미술정책연구과 이은수 주무관 서면자문 발췌

113) 채지선. 21.3.22. "미술관에 온 VR...환영과 실체, 그 경계에 서다." 한국일보. https://umw.hankoo kilbo.com/News/Read/A2021032209280004219?did=NA 
적으로 시행하고 있다. 한국어 교육, 말하기 대회, 세종문화아카데미 등은 실시간 온라 인 교육으로 전환하여 사업을 지속하였고, 우수학습자 초청연수의 경우, 한국에 방문이 가능하지 않은 점을 고려, 상응하는 부상을 제공하는 방식으로 사업내용을 대체하였 다.114) 세종문화아카데미는 외국인을 대상으로 한국의 음식 문화, 공예, 미술, 주거문 화, 혼례와 의복 등을 주제로 하여 한국문화를 소개하는 강좌프로그램이다. 이를 코로나 이전까지는 오프라인 프로그램으로 진행하였으나, 코로나19로 인하여 2020년부터 온라 인과 오프라인 사업을 병행하는 것으로 전환되었다. 2020년 오프라인 세종문화아카데 미는 21 개소 6,200 명이 참여하였고, 온라인 세종문화아카데미는 150 개소 12,082 명이 참여하였다.

\section{7) 아시아문화원}

아시아문화원은 코로나 상황에 대비한 대안적 교류협력 플랫폼 구축을 추진하며, 아 시아 6개국 협력기관(일본 날리지 캐피탈, 태국 창조경제원, 홍콩 사이버포트, 중국 날리 지시티, 태국 국가혁신기구, 대만 디자인연구소 등) 들과 공동으로 ACIC(Asia Creative \& Innovation Channel, 아시아 창조혁신채널)을 구축하여 온라인 콘텐츠 송출, 비대 면 교구재 제작 및 온/오프라인 동시 보급을 통해 코로나 19 대응을 하였다. 이 온라인 채널을 통해 ACIC 공식 출범 웹세미나를 공동 개최하는 한편, 유튜브, 페이스북 등을 통해 각 기관에서 창-제작한 콘텐츠의 라이브 스트리밍을 추진하였다. 코로나 상황에서 도 문화예술기관 교류협력 사업은 19 년 대비 20년에 약 $20 \%$ 가 증가하였다. 그리고 ICT 기반 비대면 협력 사업을 확대하고 있다. 2020년 〈텔레마틱 퍼포먼스〉를 라이브 원격공 연의 형태로 추진하였으며, 〈아시아전통오케스트라〉와 〈ACC_R Theater〉 프로그램 역 시 비대면 방식을 통해 협업을 추진한 뒤, 온라인 공연 콘텐츠를 제작하여 유통하였다. 전체 협업 콘텐츠( 54 건) 중 $50 \%$ 인 27 건에 비대면 방식을 활용하여 진행하였다.

\section{8) 영화진흥위원회}

영화진흥위원회의 교류사업은 국제영화제참가활동지원, 외국영상물로케이션 인센티 브, 한국영화 해외배급 선재물 제작지원, 필름마켓 참가지원, 국제영화제 육성지원사업,

114) 2021.07. 세종학당재단 학당지원부 정종권 부장 서면자문 발췌 
해외 장비전시회 참가지원 사업 등이 있다. 코로나 상황으로 인해서 국내외 왕래가 어렵 다 보니, 한국영화(인) 해외진출 및 네트워크 형성을 위한 각종 사업 추진이 어려웠다. 〈한-아세안 영화협력 사업〉의 경우 사업의 $80 \%$ 가 전면 중단되었었다. 〈국제영화제 참 가활동지원 사업 한국영화가 국제영화제 및 프로젝트 행사에 초청되었을 경우 참가활동비(항공료, 외국어자막 DCP 제작비 등)를 지원하는 사업으로, 2020년 3 월 이래 영화제가 온라인으로 전환되거나, 출입국이 어려운 상황으로 인해 대면 참가가 거의 이루어지지 않았다. 지원금 사용용도를 자가격리 비용, 온라인 통역인 력 비용 지원 등으로 확대하여 펜데믹 상황 속에도 참여할 수 있도록 하고 있다. 〈외국영 상물 로케이션 인센티브 지원사업>은 국내 촬영 외국영상물 제작비 일부 지원하는 사업 으로 관광유발, 고용창출 등 경제효과 제고를 목적으로 한다. 국내 입국이 어려워지며 촬영 연기, 취소 등이 발생하며 당초 사업 결정사항을 취소하거나, 예산이 불용되는 상 황이 발생하였다. 이에 비용인정기준 완화, 촬영기한 연장 등의 조치를 통해 계획이 변 경되는 상황 속에 촬영을 할 수 있도록 지원하고 있다. 〈한국영화 해외상영행사 지원사 업>은 재외공관 대상 한국영화 대면 상영행사 지원하는 사업으로, 각국 코로나19 상황 으로 인해 행사 취소 또는 비대면 전환 등으로 변경되는 등 사업계획 변경이 빈번하게 일어났다. 국가별 상황에 따라 온라인 상영 행사로 확대, 지원행사 가이드 작성 배포 등 의 조치를 진행하였다. 2020년의 대면 교류사업들은 전면 취소하였었고, 2021년은 온 라인 마스터 클래스, 화상 국제회의 등을 개최하는 등 온라인 교류사업으로 전개하였다.

2021년 사업들은 비대면 상황을 고려하여 추진하고 있다. K-CINEFLEX사업은 아리 랑tv 협업 하에 한국영화 해외홍보방송 및 광고제작하여 전 세계 송출하는 것이고, 한국 영화해외진출플랫폼(KoBiz)은 국/영/중문 사이트 전면 개편하고, 온라인 비즈매칭 플랫폼을 구축하였다. KOFIC SUPPORTS 캠페인을 통해 한국영화 세일즈 라인업 홍 보하고, Korean Acotors 200 사업을 통해 한국영화 배우 200인 해외홍보 캐스 팅북/무빙트레일러 제작, 배포하였다. ${ }^{115)}$

115) 2021. 07. 영화진흥위원회 국제교류팀 임아영대리 서면자문 발췌. 


\section{9) 예술경영지원센터}

예술경영지원센터의 교류사업은 공연예술 해외진출지원, 전통예술 해외 아트마켓 및 진출지원, 공연예술 해외진출기반마련, 서울국제공연예술제, 창작 뮤지컬 해외진출, 한 국미술 글로벌 플랫폼 운영, 한국미술 해외출판지원, 미술품해외시장 개척지원 등이 있 다. 코로나 상황에서 예술경영지원센터는 온라인 컨퍼런스·포럼 개최116), RPG(Roll Playing Game) 온라인 플랫폼을 기반으로 아트마켓 운영117), 온라인 VR 전시, 온라인 아카데미 운영, 정부 지원 대책 안내 등을 통해 코로나19 대응을 해왔다. 앞으로도 국내 외 온라인 플랫폼, 협력기관을 통한 배급 및 유통 지원, 예술인 역량 강화 교육 등을 실 시할 예정이다.

\section{0) 한국콘텐츠진흥원}

한국콘텐츠진흥원 2019년 국제교류사업은 2019 방송영상콘텐츠 포맷 제작지원사업, $\mathrm{K}-\mathrm{POP}$ 해외 쇼케이스 개최 지원, 한국패션문화 해외진출 지원, 애니메이션 해외 전시 마켓 참가 지원, 가상현실(VR)콘텐츠 사업화 지원, 캐릭터 해외진출 지원, 신흥시장 개 척 지원, 아시아 애니메이션 공동마켓 활성화 지원 등의 사업이 진행되었다. 2021년에 는 문화기술(CT) 글로벌 시장 진출 지원, 패션문화마켓(패션코드) 개최지원, 게임 유통 지원 사업(게임 수출 활성화 지원), 국제 이스포츠 페스티벌 개최, 방송영상콘텐츠 제작 지원 (국제공동제작), 국제방송영상마켓 $\mathrm{BCWW}$, 글로벌 뮤직네트워크 구축 지원 (MU:CON), 2021 캐릭터/라이선싱 온라인 해외마켓 참가 지원, 만화 해외진출 지원, 대중음악 해외진출 지원사업 등의 사업을 국제교류사업으로 계획하였다. 한국콘텐츠진 흥원은 계획된 사업을 진행하는데 있어서, 코로나19 상황을 고려하여, 비대면 행사를 중심으로 기획하고 있다.118) 온라인 교육전환, 화상수출상담회, 라이브 커머스, 백스테 이지 체험형 온라인 공연19) 등 계획된 사업을 온라인을 전화하며 코로나19에 대응하 였다. 또, 코로나 피해 제작사 융자지원을 실시했다. 2021년에는 조직 내 코로나 TFT

116) 정혜민. 20.12.28. “예술경영지원센터, 미술품 감정 및 유통 기반 구축 컨퍼런스 개최." 문화뉴스. http://uww.mhns.co.kr/news/articleView.html?idxno=424415

117) 김금영. 20.10.8. "예술경영지원센터 “코로나19 시대, 예술 한류의 새로운 공연 예술 마켓 선보일 것" 문화경제 http://weekly.cnbnews.com/news/article.html?no=136322

118) 2021.07. 한국콘텐츠 진흥원 콘텐츠수출팀 이경은 팀장 서면자문 발췌.

119) 문화일보. 2020.12.28. "한국콘텐츠진흥원, 30-31일 온택트 공연 콘텐츠 '콘투어 백스테이지' 선보여” 
추가, 메타버스 플랫폼 기반 콘텐츠 교류 사업을 비롯해 비대면·디지털 서비스 제공을 중장기화하고 있다.

\section{1) 한국국제문화교류진흥원}

한국국제문화교류진흥원은 문화체육관광부 산하 국제문화교류진흥 전담기관이다. 국 제문화교류협업 지원 및 인력양성, 국가 간 문화교류 환경조성, 민간·지역 국제문화교류 사업지원, 국제문화교류 조사.연구, 한류페스티벌 개최 및 마케팅 지원, 한류 커뮤니티 활성화, 문화분야 국제협력 사업 등으로 사업을 분류하여 다양한 국제문화교류사업을 진 행하고 있다. 한국국제문화교류진흥원은 국제문화교류 협의체를 운영하고 있다. 국제문 화교류진흥원이 주축이 되어 주한외교단, 광역 문화재단, 지방 자치단체, 문화예술 유관 기관, 주요 국제축제조직위원회가 소속원으로 활동하고 있다. 코로나 19 이전에는 정기 적으로 모이고 교류를 통해 각 소속기관이 추진하고 있는 국제교류의 내용, 형태, 어려 움 등을 공유하는 사업을 진행해왔다.

코로나 상황에서도 한국국제문화교류진흥원은 기존 사업과 신규사업을 지속적으로 추진하고 있다. 2019년에도 우리나라 우수 공연과 전시를 해외에서 선보이는 '우수프로 그램 권역별 순회〉 〈Traveling Korean Arts〉 및 국가 간 수교계기 성 문화교류, 상호교 류를 위한 행사를 대면과 비대면 방식을 병행하여 추진하였다. 2020년에는 미래혁신 문 화교류 사업을 새롭게 발굴하여 추진하고 있다. 아울러 메콩 5 개국, 러시아, 중국과 상호 문화교류도 진행하고 있다. 코로나 시대에 문화기술을 활용하여 국가간 교류를 이어나가 기 위한 사업으로 미래혁신 문화교류사업을 진행한다. 한-아세안 문화교류와 협력을 모 색하기 위한 사업으로 포럼, 전시, 지원의 3 가지로 추진하고 있다. 온라인 기반에서 한국 과 아세안의 문화혁신 전문가로 구성된 포럼과 가상현실 등을 적용한 전시를 개최하고, 문화기술을 접목하여 문화예술 국제교류 협업 과정을 지원하는 것을 주 사업 내용으로 하고있다. ${ }^{120)}$ 


\section{2) 한국공예디자인문화진흥원}

한국공예디자인문화진흥원의 국제교류사업은 한복산업 활성화 관련 해외교류, 전통 문화 해외거점 조성, 공예관광산업 육성을 위한 국제교류 및 해외 박람회 참가지원, 공 공디자인 진흥 관련 국제 타이포그래피 비엔나레 사업 등이 진행된다. 국제문화교류사업 들 중에서 코로나19로 인해 해외 주최 측의 행사성 사업 취소에 따라 개최 직전 불발된 경우가 많았다. 해외 프로그램 참가지원사업도 대부분 해외 주최 측에서 취소한 경우였다. 행사에 따라 급히 온라인으로 전환한 경우도 있으나 대부분은 대응 시기와 방법을 놓쳐 예산 불용액이 증가하였다. 121)

공예유통샵과 아카이브 센터가 임시 휴관에 들어가거나 계획된 사업들에 일부 차질이 생기기도 하였으나 재빠르게 온라인 전시, 온라인 지역공예 컨설팅122)과 사업설명회 등 비대면으로 전환하였다. 해외 교류 프로그램 등은 온라인 행사 기본 추진 + 부분 현장 행사개최 병행으로 계획하는 등 유동적으로 대처하려고 노력했다.

코로나에 대응하여 2020년에는 사업중단(공예인력 해외교류 참가 지원 / 국제공예포 럼 사업), 일부 지원금 환수, 일부 비대면 참가대체(해외박람회 참가 지원사업), 온라인 유튜브 플랫폼 영상전시를 통한 비대면 개최(전통공예의 세계화 사업) 등의 방식으로 사 업을 진행하였고, 21년에는 온오프라인을 동시에 염두한 '투트랙 사업 계획 수립'을 하 였다. 21 년도 예산은 전년에 비해 모든 사업에서 증가하였다. 이 중 ‘공예디자인진흥원 지원' 항목은 공예·디자인 아카이브센터와 온라인시스템 운영을 포함하고 있어 포스트 코로나를 반영하고 있다고 할 수 있다. 지난 5월에는 가상현실 스토어도 오픈하였다.123)

\section{3) 한국문화예술교육진흥원}

한국문화예술교육진흥원의 국제교류사업은 문화예술교육 ODA, 글로벌문화예술교육 탐방프로젝트'A-round', 온오프라인 국제교류네트워크 구축사업으로 구성되어있다. 한국문화예술교육진흥원은 국제교류사업들은 코로나 19 에 대응하기 위하여, 계획되어 있던 컨퍼런스, 학술대회, 탐방 프로젝트, 문화예술 ODA 교육 등을 비대면으로 전환하 여 진행하였다. 교류 이전 단계의 워크숍, 발표 등 zoom 등의 온라인 채널 활용 가능한

121) 2021.07. 한국공예디자인문화진흥원 공예문화 공예문화팀 정서윤 주임 서면자문 발췌

122) 서울문화투데이. 2020.12.2. “지역공예가들을 위한 온라인 컨설팅 운영"

123) 국학신문사. 2021.5.18. “공예품도 VR로 쇼핑한다, '공예정원' 가상현실(VR) 스토어 오픈” 
교류사업으로 전환 시행하였다. 2020년, 2021년 국제컨퍼런스, 학술대회, 교류워크숍 등은 모두 비대면 개최로 변경하여 진행한다. 국제문화교류사업 중에서 문화예술교육 $\mathrm{ODA}$ 사업은 비대면 방식으로 전환되어 많이 진행되고 있다.124) 2021년에는 온라인 특화 콘텐츠 개발 지원을 위한 신규 사업을 추진(20억)하고, 비대면 교육 실행을 위한 연수, 연구모임 등을 확대 및 지원, 예술 강사 역량 강화 연수 프로그램 운영을 계획하였다.

14) 한국문화예술위원회

한국문화예술위원회는 국제문화교류사업으로 한국예술국제교류지원, 예술가해외레지 던스지원, $\mathrm{ARKO}$ 국제예술확산지원, 청년예술가해외진출지원, 남북문화예술교류지원, 국제예술공동기금사업, 베니스비엔날레 한국관운영, 해외문화기관교류사업(중국문련, 몽골예술위원회, IFACCA 등) 등의 다양한 사업을 진행하고 있다. 예술분야 인적교류 분야에 대한 사업이 많고, 해외 문화예술행사 관련 사업도 있다.

코로나상황으로 인하여, 국제교류사업 중 개별 예술인(단체) 공모 지원사업의 경우, 20년 초 코로나19 팬데믹이 본격화되기 시작한 이후 사업 포기, 중단, 연기 등 돌발 변 수가 대거 발생하였었다. 이에 2020년은 국제교류지원 사업 전반에 걸쳐 코로나로 인한 불가피한 예산집행분 인정, 사업변경에 대한 탄력적 승인(내부검토 또는 심의위원 서면 심의) 등 보조금 집행·정산 및 사업내용 변경 주요사항 관련 가이드라인을 제공하여 예 술현장의 불편과 혼선을 최소화하기 위한 노력을 경주하였다. 2021년에는 공모는 지원 신청 시 코로나로 인해 당초 사업계획이 차질을 빚을 경우에 대비한 사업계획 대안(플랜 B)을 선택적으로 미리 제출토록 공모요강을 설계하였으며, 20년 예술가 해외레지던스 지원(지정형) 등 현지 주관처 사정으로 사전에 순연 승인한 일부 개별사업에 대해서는 21 년에 사업집행이 가능하도록 하였다. 직접운영 및 기획형 지원사업의 경우, 당해 연도 취소 및 차년도로 연기되거나(20년 베니스비엔날레 건축전 21년 연기) 코로나 극복 시 점까지 잠정 중단(중국문련, 몽골예술위원회 교류 등)과 같은 조치를 취하였다. 국제예술 공동기금사업 중 온라인 국제심포지엄 추진, IFACCA 온라인 이사회 참여 등의 비대면 원격 네트워킹을 통해서나마 지속가능성을 모색하는 노력도 병행하였다. ${ }^{125)}$

124) 2021.07. 한국문화예술교육진흥원 국제협력팀 김소연팀장 서면자문 발췌

125) 2021.07. 한국문화예술위원회 국제교류부 양한성 부장 서면자문 발췌 
2021년에는 예술인 안정자금확대, 비대면 예술인력 교육 컨텐츠 제작, 온라인 교육과 정 운영, 온라인 플랫폼 운영, 온라인 전시 등을 계획하였다. 코로나 상황에 따른 온라인 관련 사업이 늘어난 측면이 있다.

\section{나. 유관 부처 및 타 부처 소속기관}

\section{1) 문화재청}

문화재청은 국가 간 문화재 교류 협력으로 경험과 성과를 상호 공유함으로써 문화재 보존관리 역량 증진 및 국제사회 내 교류협력 파트너십을 형성하고, 문화재의 적극적 홍보를 통한 한국의 국제사회 내 인지도 제고를 목적으로 국제교류사업을 진행하고 있 다. 국제문화재보존복구연구센터와 협력사업을 확대 추진함으로써 국제 네트워크 강화, 아세안 국가와 문화유산 분야 교류협력 강화를 위한 한 아세안 문화유산 협력기구 신설 추진, 해외 문화유산 보수·복원 및 기술 지원 확대, 문화유산 보존역량 강화 지원 시설 장비 등 하드웨어와 매뉴얼 기술 등 소프트웨어 지원을 통해 대상국의 문화유산 보존역 량 강화, 전통문화 교육 연수 지원사업, 개발도상국 문화유산 보존 관리, 활용 인력 전문 성 강화 사업을 진행하고 있다. 이밖에도 한국 문화재 홍보, 국외소재 한국 문화재 보존 관리 지원 등 다양한 국제교류사업을 진행하고 있다.

문화재청은 코로나 대응을 위해서 전승자 공개행사 비대면 운영 지원, 온라인 환경 역량강화 교육, 일반 국민 대상 무형유산 배움터 온라인 플랫폼(네이버, 국악방송)을 활 용한 공연 송출 등 비대면 콘텐츠 제공 사업을 진행한다. 문화재청은 디지털 기술을 활 용한 다양한 사업도 진행하고 있다. 시대별 차원 공간 조성 문화유산 기록자료를 빅데이 터로 구축, 인공지능기술과 연결하여 차원 모델링을 통해 디지털 콘텐츠 제작 보급, 문 화유산 콘텐츠 문화유산에 디지털기술과 스토리텔링을 결합한 수요자 중심의 콘텐츠 개 발,126) 융복합 문화유산 콘텐츠 실감형 콘텐츠와 실제 문화재를 결합한 문화유산 향유 프로그램 제작 및 보급 등의 다양한 사업을 진행하고 있다.

126) 유무형유산(공간 시간여행VR, AR), 자연유산 힐링(미디어파사드 등), 실감형기술을 활용한 조선왕릉 가 상체험 콘텐츠 제작, 무형유산 전시미디어월 등 뉴미디어를 활용한 실감형 콘텐츠 제작, 수중문화유산 조사현장과 출수 유물 디지털 콘텐츠 구축 


\section{2) 한국국제교류재단}

한국국제교류재단의 문화교류 사업으로는 해외박물관 협력사업, 한국미술 큐레이터 직 설치, 해외 한국문화행사 지원, 한국미술 전문가 육성, 재외공관-KF 협력사업, 재외 공관 한국영화상영지원 사업이 있다. 코로나 발생으로 인하여 계획되었던 행사나 해외 인사교류 사업들의 추진에 어려움이 있었으며, 가능한 사업들 중심으로 비대면·온라인 교류로 전환하여 사업을 진행하였다. 2020년에는 세계문화교류 대면·VR전시 및 온라 인콘텐츠 개시, 해외 및 주한외국인 아티스트 협력 "KF 버츄얼콘서트 시리즈," "공공외 교 랩소디" 시행, 온라인 KF 세계영화주간 시행 등으로 코로나 상황에 대응하여 사업을 진행하였다.

2021년에는 사업계획 수립 단계부터 비대면·온라인·디지털 교류를 고려하되, 코로나 19 상황에 따라 오프라인 교류도 병행하는 방향으로 진행하고 있다. 국제교류재단은 코 로나 상황에 따라 미 평화봉사단 558명에 KF방역 키트 제공, 온라인 행사 개최, 온라인 포럼127), VR 전시 및 온라인 콘텐츠 개시 등 주로 국제협력, 문화교류 사업들은 온라인 으로 진행하는 등의 방식으로 사업을 진행했다. 2021년에는 디지털 콘텐츠 제작, 웨비 나 및 온라인 강좌 확대 방식으로 코로나 대응을 지속할 예정이다. 국제교류재단은 온라 인을 통한 문화·인적교류 다변화를 우선 추진하고, 아울러 중장기적으로도 빠르게 진화 하는 신기술을 활용한 체험형/디지털 콘텐츠도 지속적으로 확대하고자 하고 있다.128)

\section{3) 한국국제협력단}

한국국제협력단의 주요사업으로는 자금-시설 및 기술 지원 등이 결합된 국제개발협력 사업, 개발컨설팅 사업, 연수 사업, 전문 인력 파견 사업, 해외봉사단 파견 사업, 재난구 호 등 인도적 지원 사업, 국내외 민간단체와의 협력사업, 외국의 원조기관 및 국제기구 와의 협력, 국제개발협력에 관한 이념 및 정책의 수립 등을 위한 조사-연구 등의 사업을 주로 수행하고 있다. 국제문화교류 사업 중 하나인 ODA 사업의 주 수행기관으로서 방 역 $\mathrm{ODA}$, 그린 $\mathrm{ODA}$, 디지털 $\mathrm{ODA}$ 등 다양한 형태와 주제의 $\mathrm{ODA}$ 사업을 수행하고 있 다. 코이카의 전체 ODA 사업이 보고년도 기준으로 2019년 3342개이고, 2020년 2481

127) 문화일보. 2020.11.11. “한국국제교류재단, 13일 韓·日 지도층 모여 美대선 관계 전망 “한일포럼” 128) 서면자문 2021년 7월 국제교류재단 이방복 글로벌센터사업부장 자문 내용 발췌. 
개 이다. 2020년 ODA 사업의 건수가 줄어든 것은 코로나의 영향이 절대적이다. 그리고 2020년 ODA 사업 중 84건이 코로나 대응 프로젝트였다. 2020년 사업 중 코로나 대응 프로젝트를 제외하고 계속 진행되는 ODA사업은 2397건으로 2019년에 비해 1000개 가량의 사업이 중단되거나 연기되었다고 추정이 된다.

코로나 상황에 대응하기 위하여 한국국제협력단은 비대면 사업수행 체계 구축을 추진 하고 있다. 국가 간 이동 제한 등 새로운 환경에 부합하는 사업 추진을 위해 비대면(온라 인), 현장중심 수행체계 구축 및 활용(비대면 연수 등), 공공데이터 개방 요구에 부응하 고, 조직운영 및 사업관리 전반에 걸쳐 (빅)데이터 생성, 공유, 활용 강화를 통해 ODA 생태계의 디지털 전환(Digital Transformation)에 주도적으로 대응하고, SDGs 영역별 활동가이드 및 주요 분야별 성과지표 개발을 통해 글로벌 사회문제 해결에 기여하는 개 발협력 인재 양성, 개발협력 인재양성을 위한 표준역량 개발 및 이를 반영한 교육과정 개편, 표준교안 개발로 체계적인 개발협력 인재 교육시스템 구축 등을 추진하고 있다.

\section{4) 한식진흥원}

한식진흥원은 한식진흥을 위한 국제교류사업을 진행하고 있다. 세부사업으로 2019년 에는 한식 아카이브 $\mathrm{DB}$ 확산, 한식 전문강사 해외 교육기관 파견지원, 해외 호텔연계 한 식인력 해외진출 지원, 해외한식당협의체 개별사업 지원, 국내 한식문화 축제 공동 개최 사업이 진행되었다. 2020년에는 해외교류단체 지원 사업, 한식 전문 강사 해외 교육기 관 파견지원, 해외한식당협의체 개별사업 지원, 한식 전문 인력 해외진출 인프라 구축 사업이 진행되었고, 2021년에는 한식 전문 강사 해외 교육기관 파견지원, 해외한식당협 의체 개별사업 지원, 해외 호텔연계 한식인력 해외진출 지원 사업이 계획되었다.

코로나 19로 인하여 해외 현지 사정으로 인한 사업 포기와 입국 및 비자발급 제한 등으로 인력파견 사업의 수정 등의 상황이 발생하였다. 이에 한식진흥원 대면사업은 비 대면 한식 체험프로그램으로 전환하여 운영되었고, 인력파견 사업은 한식체험 밀키트 및 동영상 제작 배포 사업으로 전환되어 사업이 진행되었다.

한식진흥원은 전체적으로 코로나19 대응을 위해 코로나19 대응 관련 운영지침(현지 운영지침 철저 준수 등) 마련 및 배포, 해외 한식당 협의체 대상 방역 물품 지원, 각 사업 별 심사 방법 개선(비대면 심사 등) 등의 대응방안을 마련하였다. 사업관련해서는 코로 
나19에 따른 환경변화 대비 및 예산집행 관리를 위해 불용예산을 활용하여 신규 사업 아이디어를 내부 공모를 진행하였고, "한식 전문 인력 해외진출 인프라 구축 사업"은 인 력 파견이 어려워 비대면 한식 체험을 위해 밀키트 개발 및 영상을 제작하여 해외에 배 포 하였다. ${ }^{129)}$ 이 같은 방침은 2021년에도 계속되고 있다. 쿠킹클래스나 한식 소개, 음 식문화교류 등 체험 사업들은 온-오프라인 모두를 염두해 계획하였으며, 한식 서적 전자 책으로 제작 및 보급, 온라인 학습관리 시스템 운영도 강화할 예정이라고 밝혔다.

129) 2021.07. 한식진흥원 사업2팀 오영호 팀장 서면자문 발췌. 


\section{제2절 코로나19 이후 주요국 및 국제기구의 정책동향}

이 절에서는 코로나 19 이후 주요국과 국제기구에서 문화교류관련 대응을 어떻게 했 는지는 정리한다. 코로나가 아직까지 심각하게 진행되는 상황에서 체계적인 국제문화교 류 대응 정책이 제시된 국가는 매우 드물다.

코로나19 팬데믹은 전 세계 경제, 사회 및 정치 체제에 깊은 영향을 미쳤다. 한 분야 로서 국제관계 실천을 하는 문화 부문 또한 예외는 아니었다. 실제로 코로나19의 사회 적, 정치적, 그리고 경제적 특징들은 문화와 국제관계에서의 문화의 역할에 깊은 영향을 미쳤다. 시에나 대학교 피에란젤로 이세니아(Pierangelo Isernia) 교수의 연구 결과에 따르면, 코로나 발생으로 촉발된 비상사태와 그에 따른 방역(제한)조치들이 문화 단체들 의 국제문화관계 수행 능력에도 영향을 미치고 있음을 확인할 수 있다.130) 정부 및 비정 부 단체들은 이러한 위험을 완화하기 위해 노력하고 있거나 국제문화교류의 회복을 지 원하기 위한 대응을 수행하였다. 한편, 국가 차원으로 문화 분야 종사자(전문가)와 문화 기관들을 지원하는 것을 목표로 한 공공 또는 민간 지원방안(보조금 및 대출금에서 기술 지원까지)은 문화 단체들의 활동 및 국제교류활동을 유지할 수 있도록 간접적인 도움을 주었다. 일부 공공단체와 민간자선단체들은 국제문화교류의 기능과 방역 상황 등을 고려 하여 비상 및 복구 대응 과정을 계획 중에 있다.

130) Pierangelo Isernia \& Alessandro Giovanni Lamonica. 2021. "The Assessment of the Impact of COVID-19 on the Cultural and Creative Sectors in the EU's Partner Countries, Policy Responses and their Implications for International Cultural Relations." 


\section{1. 미주지역}

\section{가. 미국}

미국은 미국 정부에서 운영하는 문화교류프로그램들을 국무부(United States Department of State)내 교육문화부(the Bureau of Educational and Cultural Affairs)에서 주로 관장한다. 교육문화부에서 관장하는 프로그램들은 공공외교 중에서 문화외교의 한 형태로 운영되는 것이다. 주요 교류 프로그램으로는 Critical Language Scholarship Program, Fulbright Program, International Military Education and Training Program, International Visitor Leadership Program, Peace Corps, People to People Ambassador Program 등이 있다. 2020년 주요 프로그램들은 중단 되기도 하였다. 하지만, 2021년 1월 프로그램이 재개되어 진행되고 있고, 각 프로그램 별로 코로나19 대응책과 정보업데이트를 꾸준히 하면서 국가별로 대응책을 마련하여 교류 프로그램들을 진행하고 있다. 예를 들어, 청년교류 프로그램 진행 중 태국의 코로나 상황이 좋지 않다면, 태국에 대한 교류 프로그램을 중단한다.131) 풀브라이트 프로그램의 경우에 도 프로그램 참여자들의 건강 등의 상태를 확인하고, 참여자들의 모국의 코로나 상황을 고려하여 프로그램을 진행하고 있다.132) 국무부와 국토안보국의 코로나 대응 지침에 따라 프로그램별 정보 갱신과 대응책을 마련하여 프로그램을 진행하고 있다.

\section{나. 캐나다}

1) 예술가 국제교류 지원

캐나다 예술위원회는 Arts Abroad 펀드를 운영하고 있다. 이 펀드는 캐나다 예술가 들의 국제적 활동을 지원하기 위하여 조성되었다. 이 펀드를 운영하기 위해서 코로나 19에 대한 정보를 지속적으로 업데이트 하고, 캐나다 정부와 교류 대상 국가들의 관련 조치들을 따르도록 지속적으로 홍보하고 있다. 또한 코로나 19 로 인한 여러 여행제한 조 치와 행사 취소 등의 어려움 속에서도 캐나다 예술가들이 국제교류 활동을 지속하도록

131) 출처: 미국 국무부 국제교류 프로그램 홈페이지(https://exchanges.state.gov/us/youth-exchange -programs-coronavirus-covid-19) 검색일 2021년 8월 24일

132) 출처: 미국 국무부 국제교류 프로그램 홈페이지(https://eca.state.gov/fulbright/covid-19) 검색일 2021년 8월 24일 
지원하고 있다. 2019년과 2020년 기간 사이에 3천3백3십만 달러 규모의 펀드가 집행 되었다. ${ }^{133)}$

또한, 이 펀드를 통해 예술분야에 디지털 기술이 접목 될 수 있도록 관련 투자를 진행 하고 있다. 예술 작품과 활동에 있어서 디지털 기술을 활용하여 그 수준과 규모 등을 확장할 수 있도록 지원하고 있다. 디지털 관련 투자를 위해 88백5십만 달러 규모의 펀드 를 운영하고 있다.134)

\section{2) 디지털 오리지널(Digital Originals) - 마이크로 혁신 보조금135)}

캐나다 정부는 디지털 원본에 대한 보조금을 지원한다. 이는 예술가, 예술 단체, 그리 고 단체들이 온라인 공유를 위해 그들의 작업을 주도할 수 있도록 돕기 위한 이니셔티브 이다. 예술가, 단체 또는 단체들은 코로나 팬데믹 동안 캐나다 대중에게 디지털 보급에 대한 새로운 작품을 만들거나 기존 작품을 개조할 수 있다. 디지털 오리지날 펀드는 캐 나다 의회로부터 5,000 달러의 마이크로 혁신 보조금을 배정받았다. 자금 지원 프로젝트 는 전용 $\mathrm{CBC}$ /라디오-캐나다 웹사이트에 저장될 것이다. 또한 $\mathrm{CBC} /$ 라디오캐나다에서 는 디지털 $\mathrm{CBC} /$ 라디오캐나다 플랫폼 중 적어도 한 곳에서 선별된 프로젝트들을 선보인 다. 큐레이션된 CBC-라디오/캐나다 쇼케이스에 선정된 프로젝트에는 1000달러의 추가 금액이 주어진다. RBC 재단의 후원으로, 캐나다의 청소년들을 지원하기 위한 지속적인 활동의 일환으로, 신예 및 초기 직업 예술가들을 위해 15 만 달러의 디지털 오리진스 펀 딩을 이용할 수 있다. 지원 가능한 활동조건으로는 우선 코로나 19 팬데믹 상황에서 캐 나다 대중에게 디지털 보급을 위한 신규 또는 개조된 작품을 개발, 제작, 공유하기 위한 비용을 신청할 수 있다.

133) 출처: 캐나다 예술위원회 홈페이지(https://canadacouncil.ca/commitments/international) 검색일 2021년 8월 24일

134) 출처: 캐나다 예술위원회 홈페이지(https://canadacouncil.ca/commitments/digital) 검색일 2021년 8월 24일

135) https://canadacouncil.ca/initiatives/digital-originals(검색일 2021/08/26) 


\section{2. 유럽지역}

\section{가. $\mathrm{EU}$}

1) 문화 ·창작 분야(the cultural and creative sectors)활동 재개를 위한 EU 지침 (2021년 6월 29일자)

$\mathrm{EU}$ 지침은 안전한 재개와 문화 및 창조적 부문의 지속 가능한 회복을 모두 다루기 위해 EU 국가의 조치, 유럽질병예방통제센터(the European Centre for Disease Prevention and Control, ECDC)의 전문지식과 보건안전위원회(Health Security Committee)와의 정보 교류, 회원국의 다른 역학 상황과 진행 상황을 고려하여 작성되 었다.136) 유럽 위원회는 역학 상황이 개선되고 COVID-19 예방 접종 캠페인이 진행되 는 상황에 지침을 발표하였고, $\mathrm{EU}$ 회원국은 점차 문화 활동을 재개하고 있다.

\section{2) 문화 행사 참가자들과의 교류를 통한 신뢰 회복}

회원국들은 새로운 비즈니스 모델과 위기에서 벗어나기 위한 섹터들의 역량을 증가시 킬 필요성을 다루는 혁신적인 계획을 설계하고 촉진하는 것을 도와야 한다. 이 부문들은 또한 디지털 기술을 통해 관객들과 새로운 형태의 참여를 실험해 왔다. 예를 들어, 영화 가 온라인 플랫폼과 협력하는 시청각 분야나 공연 예술과 음악 분야에서도 적용되며, 축제는 관객들의 참여에 대한 혁신적인 온라인 모델에도 착수했다. 크리에이티브 유럽 (Creative Europe) 프로그램에 따라 혁신적이고 포괄적이며 지속 가능한 유통 및 공연 예술 분야의 투어 모델을 지원하기 위한 새로운 도구인 "퍼폼 유럽(Perform Europe)" 이 출시되었다. 이 프로그램을 통해서 2021년 7월 9일 마감된 1 단계에서 전체 지원자 1327 명 중에서 508명을 선발하였다. 2단계에 들어선 후보자들은 퍼폼 유럽 디지털 플 랫폼에 맞춘 창작 과정을 거쳐 서로 공동 작업을 하기도 한다. 서로 다른 배경의 작업자 들이 함께 작업을 하여 그 작품을 소개하게 된다.137)

136) 유럽연합 "Communication on EU guidelines for the safe resumption of activities in the cultural and creative sectors - COVID-19.” 2021/06/29.

137) 출처https://www.ietm.org/en/news/perform-europe-step-2(검색일 2021/08/30) 


\section{나. 영국}

Language Trends 보고서 따르면,138) 코로나 19로 영국의 학생과 교사의 국제 참여 기회가 줄어들고 있는 것으로 나타났으며, 해외 방문뿐만 아니라 해외 협력 학교와의 협력, 국제 프로젝트 참여, 어시스턴트 유치 등의 활동도 대부분 중단된 상황이라고 밝 혔다. 2021년 결과에서는 초등학생 응답자의 $64 \%$, 중학생 응답자의 $38 \%$ 가 학교 내에 서 국제 활동을 하지 않고 있으며 이는 예년에 비해 크게 감소한 수치라고 보고했다. 이에 영국 학교 관계자들은 온라인을 통해 원격 학습과 국제 교류 기회를 구축하기 위해 노력하고 있으며, 영국정부 또한 온라인 플랫폼을 이용한 문화교류 활동은 지속되고 있 으며, 향후 이를 더욱 확대하기 위해 지속적으로 노력할 것이라고 밝혔다139)

\section{1) 영국관광청 트래블마트(ExploreGB) 온라인 개최}

영국관광청이 주관하는 관광교역전인 트래블 마트(Explore $\mathrm{GB}$ )가 온라인으로 진 행되었다. 전 세계 20 여 개 국가에서 350 여 개 이상의 여행사 관계자들이 참여했으며, 행사기간 동안 1,000 개 이상의 1 대 1 비즈니스 미팅이 이뤄졌다 140$)$. 한국에서는 여행사 관계자 17 명이 참여해 영국 현지 업체들과 새로운 만남을 가졌다. 이번 행사는 5 일에 걸쳐 그리니치 시간 기준 오전 6시부터 밤 11 시까지 진행됐다. 참가자들은 코로나 19로 각자의 스케줄에 맞춰 미팅 일정에 참여하고 온라인 부스에서 영국 현지 업체들이 준비 한 새로운 관광 상품과 서비스를 확인하는 등 다양한 형태로 온라인 교류를 진행하였다.

\section{2) 영국 문화원에서 제공하는 Newton Fund 프로그램의 코로나 19에 대한 대응}

영국의 Newton Fund 프로그램은 파트너 국가와 연구 및 혁신 파트너십을 구축하여 경제 발전과 사회 복지를 지원하고 장기적으로 지속 가능한 성장을 위한 연구 및 혁신 역량을 개발하기 위해 지원된다141). 이 펀드는 영국의 비즈니스, 에너지 및 산업 전략부

138) https://www.britishcouncil.org/voices-magazine/language-trends-england-2021(검색일: 2 021/08/25)

139) 주한영국문화원 https://www.britishcouncil.kr/programmes/covid-19-updates(검색일: 2021/0 8/26)

140) https://uww.exploregb.co.uk/ (검색일 2021/08/26)

141) https://www.britishcouncil.org/education/he-science/newton-fund/partner-countries (검색일: 2021/08/25) 
가 관리하며 각 영국 파트너 국가(브라질, 칠레, 중국, 콜롬비아, 이집트, 인도, 인도네시 아, 요르단, 케냐, 말레이시아, 멕시코, 페루, 필리핀, 남아공, 태국, 터키, 베트남)에 지 원된다. 영국 문화원은 코로나 19로 인하여 전 세계 연구 및 혁신 커뮤니티의 지속이 어려운 상황임을 인지하고 있으며, 항상 교육이 전 세계 사람들을 연결시키고 코로나 19 팬데믹이라는 불확실성의 시기에 무엇보다 교육이 중요하다는 점을 강조하고 있 다.142) 코로나 19 시대에 전 세계 사람들이 교육에 접근할 수 있고 교류가 가능하도록 단체, 기관, 자금지원부처와 협력하여 온라인을 통해 Newton Fund 정보 및 많은 활동 을 전달하고자 노력하고 있다. 다만, 계획된 프로젝트들은 코로나 19 방역 상황에 따라 보류중이며, 2021년 7얼 3500만 파운드의 예산이 지원될 새로운 영국문화원이 관리하 는 Newton Fund 프로그램 또한 코로나 19로 보류중이다.

\section{3) 영국 문화원의 온라인 문화교류}

영국 문화원은 코로나 19 상황에서 문화 교류를 지속하기 위해 다양한 온라인 행사를 마련하였다143). 온라인 행사는 아티스트와 크리에이티브 전문가를 모아 국가 간 성과, 아이디어 및 지식을 공유한다.

(1) 위기 속의 문화(Culture in Crisis: Global Heritage Perspectives)

[그림 3-3] 위기 속의 문화 웨비나 영상

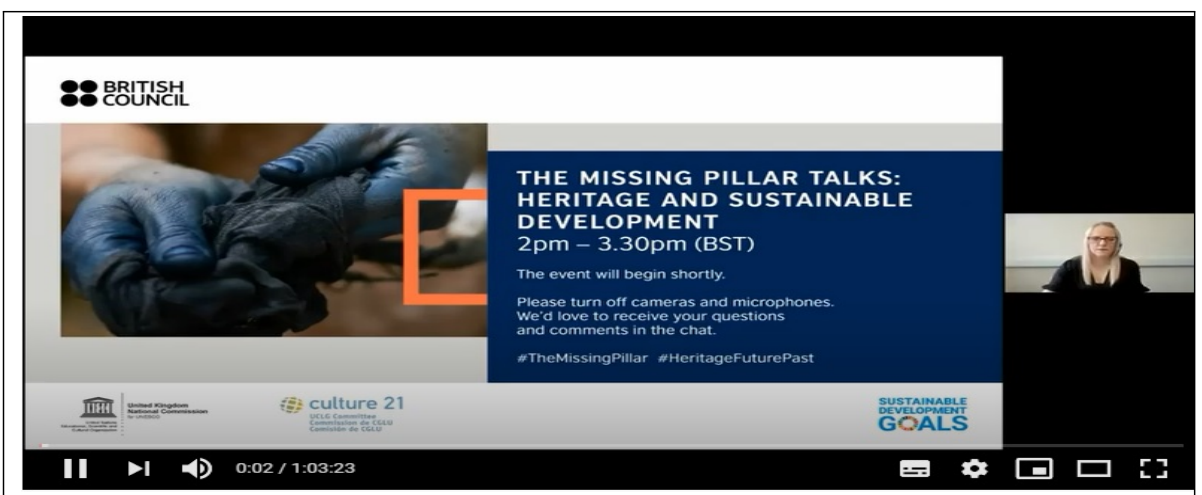

출처: https://youtu.be/83iTxI0M9uA 검색일 2021년 8월 25일

142) https://uww.britishcouncil.org/education/he-science/newton-fund/response-covid-19 (검색일 2021/08/25)

143) https://uww.britishcouncil.org/arts/events(검색일 2021/08/25) 
디지털, 문화, 미디어 및 스포츠 부처, 영국 위원회, 빅토리아와 앨버트 박물관(the Victoria and Albert Museum)이 지원하는 온라인 문화 프로그램으로 대화형 웨비 나 행사인 '위기 속의 문화: 글로벌 유산 관점'을 2021년 8월 23일 개최하였다. 이 행사를 통해 전 세계의 개인과 조직이 함께 모여 국제적 경험과 모범 사례를 공유하며, 지역사회와 조직이 탄력적으로 회복되고 보다 지속 가능하고 평등하며 생태적인 미래 를 모색하였다.

(2) 온라인 언어 · 문화 교육 \#CultureConnectsUs

영국 문화원은 코로나 19 팬데믹으로 인한 거리두기 상황에서도 지속적인 교류의 중요 성을 강조한다.144) 국제문화와 교육이 어려운 상황에서 세계 여러 나라의 생활과 문화에 대해 온라인 영상을 제작하여 태그 \#CultureConnectsUs를 달아 SNS상에 배포하고 있 다. 교육 전문가에 의해 전문적으로 설계되고 현직 교사에 의해 검증된 동영상은 직접 또는 온라인 수업을 계획하는 전 세계 학부모들의 홈러닝(home-learning)을 지원하는 데 도움이 되는 주제로 제작되었다. 학생들이 가상 세계 여행을 계획하고 탐험하고자 하는 나라를 선택하여 시간과 장소에 구애받지 않고 안전한 학습을 진행할 수 있다. ${ }^{145)}$

\section{다. 프랑스}

\section{1) 온라인 플랫폼을 통해 문화콘텐츠 제공}

프랑스 문화부 산하기관은 사회적 거리두기 기간 중에도 문화예술 콘텐츠를 향유할 수 있도록 분아별 온라인 플랫폼을 운영 중이다. 각 기관마다 문화 향유층에 알맞은 콘텐츠 를 맞춤 제공하며, 대표적인 시례는 아래와 같다. 우선, 라디오 채널 프랑스뮤직(France Musique)·파리 오페라·코메디 프랑세즈(Comedy Français)· 파리 필하모니의 콘서트, 공연영상 등 무료 상영. 둘째, 프랑스국립시청각연구소(INA)·TV방송 아르테(ARTE)·베르 사이유 궁전의 시청각자료, 영화, 다큐멘터리 무료 상영. 셋째, 오르세미술관·라빌레트(La Villette)·클루니국립중세미술관·국립건축센터·그랑팔레: 디지털 전시 및 아카이브 자료 제공, 넷째, 프랑스국립도서관(BNF)의 도서, 시청각·교육자료 제공 등이 있다.

144) https://umw.britishcouncil.org/school-resources/around-world(검색일 2021/08/25)

145) 출처: https://uww.britishcouncil.org/school-resources/around-world(검색일 2021년 8월 25일) 


\section{2) 프랑스어 홍보를 위한 글로벌 디지털 캠페인146)}

프랑스 문화원(Institut français)은 18-25세 청년층의 프랑스어 학습을 장려하기 위 해 \#plusloin 이라는 디지털 캠페인을 시작하였다. 이 캠페인은 웹 사이트, SNS, WhatsApp에서 액세스할 수 있는 전화번호로 이용할 수 있으며, 이로 인해 전 세계 젊 은이들이 프랑스어로 대화할 수 있게 하였다. 이 캠페인은 프랑스어를 공유한 인물들과 재능의 과정을 강조하며, 제인 버킨, 블랑카 리와 같이 많은 국제 영향력을 가진 젊은 사람들을 대상으로 프랑스어를 사용하는 재능 있는 사람들로 구성된 글로벌 커뮤니티를 만드는 것과 프랑스어로의 교류 증진을 위한 결합을 목표로 하고 있다.

이 캠페인의 목표는 두가지 이다. 첫째, 프랑스어가 국제적 차원에서 현대적인 언어이 며 개방성과 전문적인 기회의 언어임을 보여준 것이다. 둘째, 해외 프랑스 문화 네트워 크와 젊은이들이 언어 능력을 개발하고 국내 및 국제 수준에서 전문적인 성공을 거둘 기회를 제공 할 수 있도록 관계를 심화시키는 것이다.

프랑스 문화원은 COVID-19 유행에 영향을 받은 프랑스 문화 네트워크 기관의 해외 활동을 지원하고 지원함으로써 언어 과정(온라인 및 원격 과정 포함) 등록에 유리한 동 력을 창출하고자 한다. 이 캠페인은 프랑스 대사관, 프랑스 연구소 및 프랑스 연합의 문 화 서비스들로 구성된 이 전체 네트워크와 공동으로 구성된다. 프랑스어와 다국어주의를 위한 프랑스 정부의 계획에 따라 \#plusloin은 프랑스어를 사용하는 공간의 다양성과 역 동성을 장려함으로써 프랑스어를 개방적이고 다원적인 관점으로 배치하는 것을 목표로 하고 있다. 프랑스 문화원은 또한 프랑스어권 문화 공간을 분리하기 위해 전 세계에서 수많은 활동을 추진하고 있다.

\section{3) 새로운 레지던시 프로그램 개발 모색147)}

프랑스 문화원은 25 년 이상 프랑스와 전 세계의 예술가 거주지를 개발하고 지원하는 프로그램을 운영해왔다. 코로나로 인하여 변화된 상황에서 당초 2020년 3월에 개최 예정 이었던 레지던시관련 컨퍼런스인 “Reflecting Residencies conference”를 2020년 10

146) 출처: gitale-de-promotion-du-francais https://www.institutfrancais.com/fr/zoom/presenta tion-de-la-campagne-mondiale-di 검색일 - 2021년 6월 2일

147) 출처: https://umw.institutfrancais.com/fr/zoom/colloque-reflecting-residencies-les-reside nces-artistes-au-prisme-des-enjeux-actuels 검색일 - 2021년 6월 2일 
월 22일과 23일 간 개최하며 레지던시 프로그램 관련 정책을 새롭게 구성하는 것에 대하여 모색을 하고 있다. 프랑스 문화원에서는 프랑스와 전 세계의 다양한 레지던시 프로그램을 분석하는 것을 목표로 Residences Arts en Residence - National Network와 연합하여 Reflection residenties 컨퍼런스를 지원하고 있다.

또한 프랑스문화원은 Villa Saint Louis Nda와 같은 해외의 프랑스 문화 네트워크와 제휴하여 개발된 새로운 레지던트 프로그램이나 유럽 기금에 의해 지원되는 프로그램인 i-Portunus와 Be Mobile, Create Together 등의 프로그램 개발과 시행을 준비하고 있다.

\section{4) 코로나19 상황 대처를 위한 해외 프랑스 문화네트워크 정보공유}

프랑스 문화원은 코로나 상황을 극복하기 위하여 해외 각 프랑스 문화원들이 개발한 이니셔티브들을 공유할 수 있도록 네트워크를 구성하여 운영하고 있다. 개발된 이니셔티 브들은 다음의 표의 내용과 같다.

〈표 3-17〉 프랑스 문화원 네트워크 코로나 대응 이니셔티브

\begin{tabular}{|c|c|}
\hline & $\begin{array}{l}\text { - 호주 알리앙스프랑세즈 : 그들의 사회적 네트워크에 대한 다양한 문화적 및 교육적 정보를 공유 } \\
\text { 하기 위해 \#EntakeEnLine을 설립 }\end{array}$ \\
\hline & $\begin{array}{l}\text { - 싱가포르 알리앙스프랑세즈 : 일반 대중이 코로나 } 19 \text { 상황에서 최대한 문화 생활을 할 수 있도 } \\
\text { 록 온라인 문화 제안들을 제공함 : 영화, 사진, 공연예술, 음악, 시각예술, 문학 등 } 6 \text { 개 주요 } \\
\text { 테마로 구성 }\end{array}$ \\
\hline & $\begin{array}{l}\text { - IFAL in casa : 주 라틴아메리카 프랑스문화원은 "IFAL en casa"를 제안함. 모든 취향과 온 } \\
\text { 가족을 위한 프랑스 및 온라인 문화 제공( 컨퍼런스, 콘서트, 연극, 인터뷰, 춤, 책들 } \cdots)\end{array}$ \\
\hline & $\begin{array}{l}\text { - 모리셔스 프랑스문화원 : 현재 상황에 의해 악화되고 있는 일상에서 사람들에게 다양한 이니셔티 } \\
\text { 브를 대중에게 제안함IF의 소셜 네트워크에서는 \#ParLaFenätre가 출시되어 두 달 동안 } 120 \text { 개 } \\
\text { 의 게시물이 Facebook 페이지에 게시됨 }\end{array}$ \\
\hline $\begin{array}{c}\text { 다분야 } \\
\text { (Pluridisc } \\
\text { iplinaire) }\end{array}$ & $\begin{array}{l}\text { - 엄선된 책을 선보이는 IFM 미디어 도서관장이 시작한 '독자의 카페' } \\
\text { - 월간 예술 계발 Zapero를 시작함. 소셜 네트워크에서 45분동안 방송되는 형식으로 새롭게 떠오 } \\
\text { 르는 모리셔스의 장면을 만날 수 있으며, IFM 팀, 아티스트 및 Zapéros 프로그래밍위원회가 } \\
\text { 진행하는 프로그램임 } \\
\text { - 대중적인 성공을 위해 코로나 } 19 \text { 위기를 넘어서도 지속성을 고려할 뿐 만 아니라 디지털 자원, } \\
\text { 특히 대중과의 실제 연결을 위해 소셜 네트워크의 더 많은 사용을 고려하려는 계획에 있음 }\end{array}$ \\
\hline & $\begin{array}{l}\text { - 트리폴리 프랑스문화원 : 어린이들과 어른들에게 최대 } 1 \text { 분 분량의 비디오 형식으로 프랑스어로 } \\
\text { 연대 메시지를 보내달라고 요청했고, 광고 이후 하루 평균 } 3 \text { 개의 영상을 받는다고 밝힘 }\end{array}$ \\
\hline & $\begin{array}{l}\text { - 튀니지 프랑스문화원 “la web-TV Des/confinés” : 튀지니 프랑스문화원은 지중해 연안의 인 } \\
\text { 물들과 인터뷰 프로그램을 시작했으며, 프로그램명은'Des / confined’ 라고 불리며 30-40분 } \\
\text { 짜리 ㅇㅞㅞ TV 프로그램임 } \\
\text { - 매주 수요일 오후 3시 30분에 페이스 북에서, 매주 목요일과 금요일 오후 8시에 유튜브와 트위 } \\
\text { 터에서 } 3 \text { 번의 인터뷰가 방송됨. }\end{array}$ \\
\hline
\end{tabular}




\begin{tabular}{|c|c|}
\hline \multirow{7}{*}{ 영화 } & $\begin{array}{l}\text { - 태국 프랑스문화원 : 방콕의 문화원은 프랑스 정부의 \#CultureChezNous 제안과 함께 베르사 } \\
\text { 유 성과 루브르 박물관, 거울의 방 가상 방문 등을 페이스북에 게재함 }\end{array}$ \\
\hline & $\begin{array}{l}\text { - 알제리 프랑스문화원 : 알제리 프랑스문화원의 다큐멘터리 워크숍에서 제작된 다큐멘터리를 청 } \\
\text { 중에게 무료로 제공 }\end{array}$ \\
\hline & $\begin{array}{l}\text { - 피렌체 프랑스 문화원 : 피렌체 프랑스문화원의 Manon Hanseman 소장은 연구소의 Youtube } \\
\text { 채널을 통해 프랑스 코미디 프로그램을 공개하고 있음. }\end{array}$ \\
\hline & $\begin{array}{l}\text { - 모로코 프랑스문화원 : 6-12 세 어린이가 영화에 대해 설명하고 만들고 싶어하도록 5분 동안 } \\
\text { 지속되는 교육적이고 재미있는 캡슐 시리즈 "Ciné-Moi"를 제공 } \\
\text { - 매주 일요일, 모로코 프랑스문화원은 이들에게 연구소의 Facebook 페이지에 게시 할 비디오를 } \\
\text { 만들 수 있는 기회를 제공 }\end{array}$ \\
\hline & $\begin{array}{l}\text { - 카사블랑카 프랑스문화원 'L'heure du conte' : 페이스북을 통해 매일 프로그래밍을 제공하며, } \\
\text { 매주 수요일에는 " L'heure du conte »라는 제목의 세션을 찾을 수 있는데, 이 세션에서는 } \\
\text { 작품의 삽화가 곁들여진 이야기꾼의 이야기를 다룸 } \\
\text { - 매주 화요일, 카사블랑카 프랑스문화원 페이스북 페이지는 영화 다큐멘터리 애호가를 공유함 }\end{array}$ \\
\hline & $\begin{array}{l}\text { - 멕시코 \& 인도네시아 프랑스 문화원 : 멕시코 IFAL 은 SPOTIFAL이라는 플레이리스트를 통해 } \\
\text { 관객들에게 프랑스 음악을 소개함. 이는 Netflix Indonesia에서 프랑스 애니메이션에 대한 접근 } \\
\text { 을 촉진하고, 또한 Netflix Indonesia - Divines, Un + one, Budapest } \cdots \text { 에 대한 프랑스 영 } \\
\text { 화의 일일 추천을 통해 시청자들을 안내하는 프랑스 협회와 마찬가지로 Netflix Indonesia에서 } \\
\text { 프랑스 애니메이션에 대한 접근을 촉진함 }\end{array}$ \\
\hline & $\begin{array}{l}\text { - 나폴리 프랑스 문화원 : 봉쇄 명명으로 SNS 상에서 재미있는 캠페인을 진행함. 매주 테마가 } \\
\text { 제시되고, 네티즌은 이 테마와 관련된 사진을 공유해야 하며, 그 다음 최고의 사진은 나폴리 프 } \\
\text { 랑스문화원 소셜 네트워크를 통해 공개되는데 성공을 거둔 이니셔티브로 제시 }\end{array}$ \\
\hline \multirow{4}{*}{ 언어 } & $\begin{array}{l}\text { - 리마 알리앙스프랑세즈: 네트워크에 비디오 커뮤니케이션 키트를 공유할 수 있는 Google 드라 } \\
\text { 이브를 제공 }\end{array}$ \\
\hline & $\begin{array}{l}\text { - 로자리오 알리앙스프랑세즈 : 칸바(Canva) 온라인 애플리케이션을 통해 인스타그램 스토리 키 } \\
\text { 트를 네트워크를 통해 공유하는데, 처음에는 스페인어로 작성된 콘텐츠이지만 모든 언어로 조정 } \\
\text { 할 수 있음 }\end{array}$ \\
\hline & $\begin{array}{l}\text { - 프랑스 문화원(프랑스 본원)“COVID-19 et FLE, nos solutions pour nos } \\
\text { établissements(COVID-19 및 FLE, 우리 시설을 위한 솔루션) : 유튜브 채널을 통해 } \\
\text { "COVID-19 및 FLE, 우리 시설을 위한 솔루션” 영상 제공. 이 영상들은 전 세계 동료들과 문화 } \\
\text { 네트워크의 특정 시설에서 코로나 } 19 \text { 상황을 다루기 위해 해외에서 제공하는 다양한 응답을 수 } \\
\text { 집하여 제공함. 특히 원격 교육을 용이하게 하는 디지털 도구의 프레젠테이션을 통해 이러한 어 } \\
\text { 려운 상황에도 불구하고 이 상황을 해결하고 교육적 연속성을 유지하기 위한 솔루션과 이니셔티 } \\
\text { 브를 제공 }\end{array}$ \\
\hline & $\begin{array}{l}\text { - 프랑스 문화원(프랑스 본원) “les Webinaires IFprofs pour partager et mutualiser les } \\
\text { bonnes pratiques du réseau(네트워크의 모범 사례를 공유하고 통합하는 IF prof 웨비나) } \\
\text { COVID-19 팬데믹이 시작된 이래, 프랑스문화원은 일주일에 한 번씩 교육 및 언어, 협력을 위 } \\
\text { 해 프랑스 연구소, 알리앙스 프랑세즈 및 동료들이 제공하는 정보를 공유하기 위해 웨비나를 진 } \\
\text { 행함. 이러한 지속적인 네트워크를 통해 교육적, 사회적, 문화적 연속성을 유지하고자 노력 }\end{array}$ \\
\hline 음악 & $\begin{array}{l}\text { - 부쿠레슈티 프랑스문화원 : 루마니아 프랑스문화원은 참가자들이 지난 } 10 \text { 년 동안 프랑스 레퍼토 } \\
\text { 리의 노래를 부르면서 등록해야 하는 온라인 통역 콘테스트인 프랑스마니아를 온라인으로 제공 }\end{array}$ \\
\hline
\end{tabular}




\section{라. 독일}

\section{1) '집에서 경험하는 독일' 온라인 관광 프로그램 운영}

독일관광공사(DZT)는 코로나19 사태로 관광업이 중단된 현 시점에도 “\#Discover GermanyFromHome(집에서 경험하는 독일)' 캠페인을 통해 독일 관광 사업을 홍보하고 있다. 이 캠페인은 여행 제재 조치 중에도 관광객과 지속적으로 소통하며 독일을 알리고 미래 관광객을 유치하는 것을 목표로 한다. 독일 관광공사는 30 개 이상 채널을 통해, 독일 16 개 주에 대한 관광지 가상체험, 인터랙티브 지도, 독일에 대한 퀴즈, 독일 음식 레시피 등 독일 여행 관련 다양한 콘텐츠를 제공하고 있다. 또한, 독일을 방문할 잠재적인 관광객을 위해 여행계획, 여행방법, 관광 상품 등에 대한 최신 정보를 제공할 예정이다. 이 캠페인은 3월 16 일에 처음 시작된 후, 독일 관광공사 채널을 통해 지금까지 960 만 명에게 도달했으며, 외부 채널을 통해서는 19,000 건의 캠페인이 추가 발생했다.

[그림 3-4] 독일 관광공사 ‘Discover Germany From Home’ 페이지

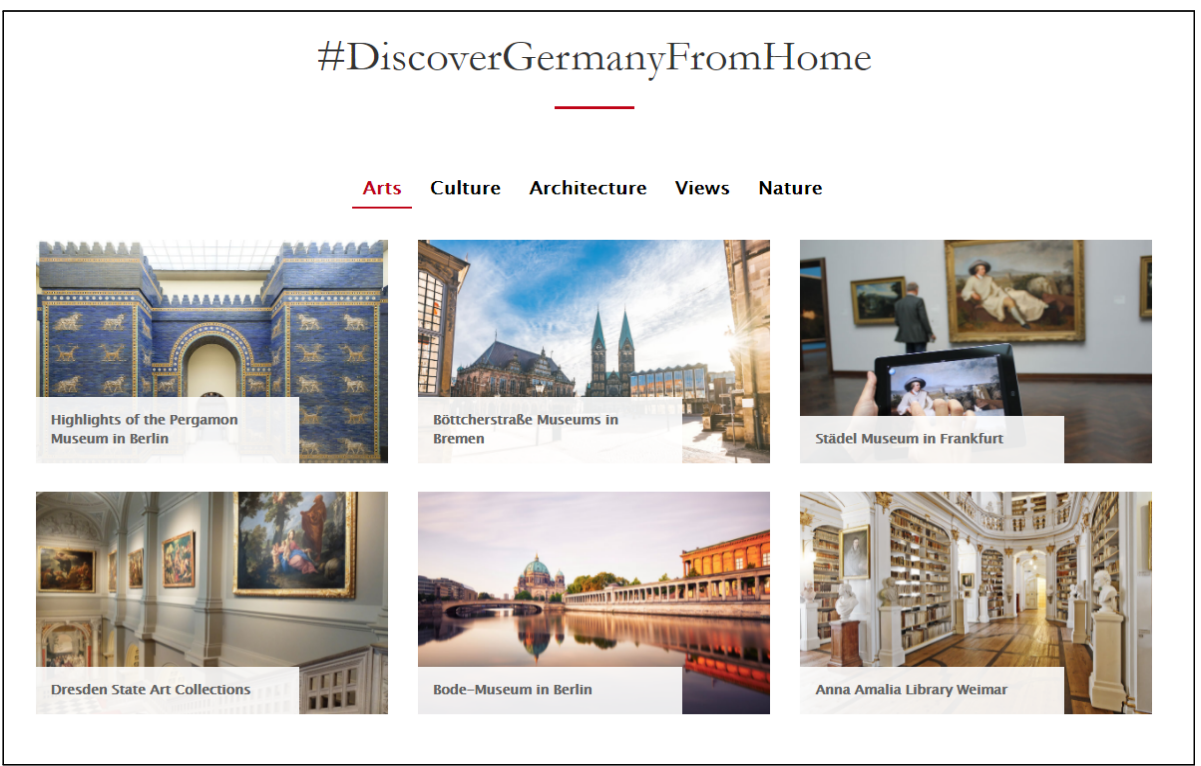

출처: https://hww.germany.travel/en/ms/discover-germany-from-home/discover-germany-from-home.html. 검색일 - 2021년 5월 20일 
2) 독일 연방 외무부 및 괴테 연구소 문화와 교육 기관을 위한 2020 국제 구호 기금

이 기금은 파트너 국가의 기관을 지원함으로써 국제 문화 협력이 지속되도록 하기 위 한 것이다. 이 이니셔티브는 COVID-19 전염병의 결과로 고통 받고 있고 다른 자금원 에 접근할 수 없는 유럽 연합 이외의 국가에 기반을 둔 문화 기관을 위한 것이다. 인프라 유지보수, 재개발 프로젝트, 새로운 디지털 포맷의 개발 또는 디지털 교육 및 자격 증명 과 같은 지원도 단기적이고 직접적인 경제 지원(프로젝트당 최대 25,000 유로)에 국한되 지 않는다. 괴테-인스티튜트와 연방 외무부의 주도이지만, 구제 기금은 독일의 문화 단 체와 민간 재단, 즉 독일 유네스코 위원회인 $\mathrm{DAAD}$ 의 베를린어 귄슬러 프로그램의 지원 을 받고 있다. Fischer Foundation, Mercator Foundation, Robert Bosch Foundation 및 Siemens Foundation. 외무부는 초기 기부금 300만 유로를 지원했고 컨소시엄의 다른 회원들은 추가 자금을 지원했다.

\section{마. 이탈리아}

1) 'Italy's streaming platform'(ITsART) 구축 추진

이탈리아 문화부는 이탈리아 문화에 비용을 지불하고 접근할 수 있는 온라인 플랫폼 구축을 위하여 1000만 유로의 예산을 배정하였다. 이 플랫폼은 일명 'Netflix of Italian culture' 로 불리었으며, 정식 명칭은 ITSART로 정해졌다. 이 플랫폼은 유료와 무료 콘텐 츠를 모두 운영하며, 이 플랫폼을 통하여 이탈리아 음악, 오페라, 연극, 영화, 다양한 박물관 소장품 등에 대한 접근이 이탈리아 국내뿐만 아니라, 해외에서도 가능하도록 하는 것이 목적이다. 이탈리아 문화부 장관은 다리오 프란세스치니(Dario Franceschini) 이 스트리 밍 이니셔티브를 ‘문화 넷플릭스의 한 종류’라고 표현하였다. ${ }^{148)}$

148) 출처: Wnated in Rome https://www.wantedinrome.com/news/italy-proposes-netflix-of-it alian-culture.html 검색일 - 2021년 5월 20일 


\section{3. 아시아태평양 지역}

\section{가. 일본}

일본은 문화분야의 코로나 대응과 디지털 기술 환경에 대응하기 위하여 관련 프로그램을 준비하였다. 문화진흥원이 물리적 인프라와 디지털 니즈를 모두 지원하는 5200만 유로를 배정받았으며, 일본국제교류재단이 온라인 활동을 위한 다수의 보조금을 포함하는 문화교 류 프로그램에 긴급지원을 마련하고, 다양한 디지털 이니셔티브기관들도 출범시켰다.

\section{1) 코로나19에 대한 대응 프로그램 운용}

일본국제교류기금 (Japan Foundation)은 코로나 19 팬데믹 이후 예술, 문화, 일본어 교육, 일본학, 지적교류 등 많은 프로그램이 중단되거나 취소되었다. 이에 대응하기 위한 방안을 구성하였다. 첫 번째, JF digital collection 웹페이지를 별도로 구성하여, 온라인 문화표현과 대화창구로 활용하고 있다. JF digital collection은 국제교류기금 일본 본부 와 전세계 사무소에서 진행하는 온라인 프로그램을 모두 보여주는 온라인 플랫폼이다.

[그림 3-5] JF digital collection 웹페이지
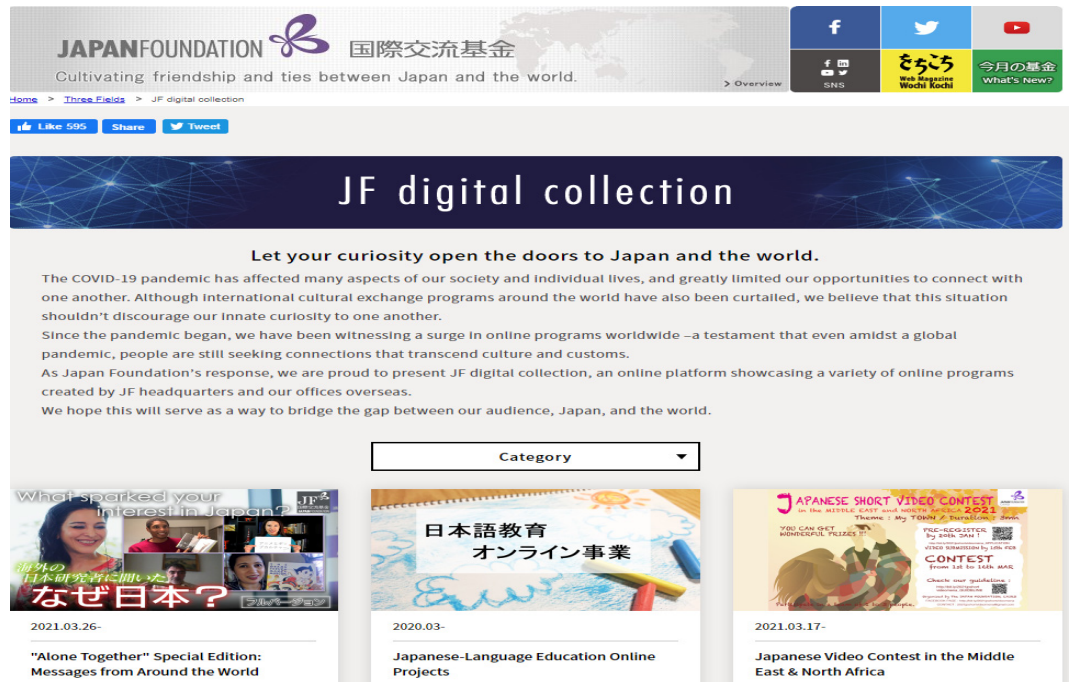

출처: https://uww.jpf.go.jp/e/project/digital_collection/index.html. 검색일 - 2021년 5월 20일 
두 번째, 일본어를 배우고자 하는 외국인을 대상으로 하는 일본어 교육프로그램에 이 러닝 시스템을 적극 활용하고 있다. 일본은 일본어 교육 이러닝(e-learning) 프로그램을 운영하고, 관련 정보를 확인할 수 있는 웹페이지(Minato)를 구성하여 운영하고 있다. 이를 통해 해외에서도 온라인으로 일본어 교육을 계속 할 수 있도록 하였다. 이러닝 홈 페이지에서는 여러 유형의 일본어 교육 프로그램에 접근할 수 있고, 관련 커뮤니티에 대한 접근도 안내하고, 국제교류기금 이외에 일본어 교육 프로그램 운영 현황과 관련된 정보를 제공하여 해외 사용자들이 쉽게 관련 정보에 접근할 수 있도록 하였다.

\section{2) 일본영화 온라인 상영}

일본국제교류기금은 2020년 6월 11일부터 중국의 대형 배급사 텐센트 비디오와 공 동개최로 중국에서 온라인 발신하는 일본 영화제를 실시하고 있다. 이 사업에서는 텐센 트 비디오가 권라를 가진 일본 영화 61작품을 회원들에게 상영하고 있다. 이 회사의 회 원 수는 1억명 이상으로 일본 영화제 특설 페이지 공개부터 6일 만에 접속 수(PV수) 190만을 넘었다. 일본국제교류기금은 2017년 '중일 국교 정상화 45주년', 2018년 '중 일 평화 우호조약 체결 40 주년' 등 외교 상의 전환점을 기념하여 중일 양국에서 서로의 영화를 소개하는 영화 상영회를 개최하여 2019년도에도 중국 9개 도시에서 일본 영화 상영회를 개최. 중국에서 일본 영화를 즐길 수 있는 기회를 지속적으로 창출하고 있다. 또한 '언제 어디서나 일본 영화'를 캐치 프레이즈로 내걸고 ASEAN 국가들, 호주, 중국, 인도, 러시아에서 최신 일본 여화를 각 국 언어 자막을 넣어 제공하는 JFF (Japanese Film Festival) 을 계속적으로 전개하고 있다.149)

\section{3) ‘아시아 시민교류 조성 프로그램’ 기획}

일본국제교류기금의 국제교류기금 아시아센터는 코로나 대응을 위한 신규 프로그램 으로 '아시아 시민교류 조성 프로그램'을 기획하였다. ASEAN 국가들이 중심이 되는 아 시아와의 문화교류 사업을 기획·실시하는 일본 국내단체를 대상으로 관련 경비를 지원 하는 프로그램이다. 국가 간 이동을 하지 않고 온라인 사업 중심의 교류사업을 지원하는

149) 일본국제교류기금 보도자료. 2020. 6.17.【取材のお願い】中国で「オンライン配信日本映画祭」を開催 6 日間でアクセス数190万を記録 
프로그램이다. 1 개 사업 당 200만 엔을 상한으로 하고 있으며, 2020년 6월 1일부터 시행하고 있다. ${ }^{150)}$

\section{나. 중국}

코로나로 인한 중국 문화산업의 급격한 위축은 또한 중국의 국제 무역과 특정 관점에 서는 국제문화관계에도 영향을 미쳤다. 북경대학교 문화산업연구에 따르면 문화상품은 중국 문화수출의 중요한 부분으로 2018년 전체 수출의 50.6\%를 차지하며 2\%의 성장률 을 보이고 있다. 공연예술은 2018년 9.9\%, 2019년 5.9\%의 성장률을 보였다. 다만 전 체 중국 문화수출의 59.6\%가 미국, 네덜란드, 영국, 일본 등 4 개 시장에만 흡수된다는 점에서 국내 문화부문의 위기는 수출에 부정적인 영향을 미칠 것이며 교역상대국의 대 칭적 위기로 피해가 증폭될 것으로 보인다. 이러한 손실의 일부는 중국에서 크게 확장되 고 있고 문화적인 성격의 해외 무역의 큰 부분을 차지할 디지털 시장에 흡수될 것이므로 예상하고 있다.151)

지방정부 단위에서 디지털 기술을 활용한 중점 발전 분야 정리와 발전 방안에 대한 계획이 발표되기도 하였다. 상하이 지방정부는 자체적으로 디지털 기술을 활용한 경제발 전 방안을 마련하여 발표하였다. 2020년 4월 8일 상하이 시정부는 코로나 19 팬데믹 이후 새롭게 대두될 거대한 사회적 변화에 발맞춰 향후 3개년의 '상해시 온라인 신경제 발전촉진의 행동방안(上海市促进在线新经济发展行动方案(2020 2022), (이하 '행동방 안'))을 발표했다. 상하이에서 발표한 '행동방안'에는 인공지능, $5 \mathrm{G}$, 인터넷, 빅데이터, 블록체인 등 첨단 IT산업과 생산 제조, 금융 비즈니스, 문화 및 여가소비, 교육, 건강, 물류 유통 등 기존의 여러 분야와의 기술 융합을 통해 새로운 산업모델의 태동과 발전을 목표로 삼고 있다. 12 개 중점 발전 분야 중 문화영역과 관련하여 온라인 문화엔터테인먼 트 분야와 온라인 전시회가 포함되어 있다. 문화산업의 온라인 발전을 가속화하고, 전시 서비스 플랫폼 구축과 클라우드 회의, 전시, 체험관 제작을 적극 추진하기로 하였다. 이 를 통한 다양한 문화교류 사업이 진행될 수 있을 것으로 보인다.

150) 출처: https://bijutsutecho.com/magazine/news/headline/21988 검색일 - 2021년 5월 20일

151) 출처: https://cmobile.g-enews.com/view.php?ud=20200429195137181532_7\&md=202005 08000011_R 검색일 - 2021년 5월 20일 
〈표 3-18〉 상하이시 온라인 신경제 발전촉진의 행동방안 12 개 중점발전분야

\begin{tabular}{|c|c|c|}
\hline 연번 & 분야 & 주요내용 \\
\hline 1 & 무인공장 & $\begin{array}{l}100 \text { 개 이상의 무인 공장, 무인 생산라인, 무인 작업장을 건설해 외부요인 및 근로에 비 } \\
\text { 교적 유연한 생산환경을 구축하고 플렉시블 제조·클라우드 제조·공유 제조와 같은 새로 } \\
\text { 운 제조방식의 발전에 초점 }\end{array}$ \\
\hline 2 & 공업인터넷 & $\begin{array}{l}\text { 대형 기업의 인터넷 전용망 설치를 지원하며, 전국적인 영향력을 갖춘 } 20 \text { 개의 공업 인터 } \\
\text { 넷 플랫폼을 건설 }\end{array}$ \\
\hline 3 & 원격근무 & $\begin{array}{l}\text { 온라인을 통해 시간과 장소를 초월한 협업체계 구축하고 } 5 \mathrm{G} \text { 기술의 응용을 가속화해 } \\
\text { 업무의 효율성을 제고시키는 등 원격근무가 사회에 빠르게 보급될 수 있도록 노력 }\end{array}$ \\
\hline 4 & 온라인 금융 & $\begin{array}{l}\text { 온라인 대출 신청·연장·상환 및 재테크 투자 등의 편의성 제고와 활성화 방안을 마련하고 } \\
\mathrm{Al} \cdot \text { 빅데이터·블록체인의 융합과 '인터넛+의료건강+보험을 통합한 건강보험 일체화 서비 } \\
\text { 스 플랫폼을 구축 }\end{array}$ \\
\hline 5 & $\begin{array}{l}\text { 온라인 문화 } \\
\text { 엔터테인먼트 }\end{array}$ & $\begin{array}{l}\text { 오디오·숏 클립 영상·라이브 방송 등의 인터넷 시청을 위한 발전방향 모색과 인터넷 모바 } \\
\text { 일 게임·인터넷 문학·애니메이션·e스모츠 등 온라인 엔터테인먼트 분야의 발전을 가속화 }\end{array}$ \\
\hline 6 & $\begin{array}{l}\text { 온라인 } \\
\text { 전시회 }\end{array}$ & $\begin{array}{l}\text { 대형 전시업체와 유명 클라우드 서비스 기업 간 공동 클라우드 전시 서비스 플랫폼 구축 } \\
\text { 및 클라우드 회의·전시·체험관 제작을 적극 추진 }\end{array}$ \\
\hline 7 & $\begin{array}{l}\text { 신선식품 } \\
\text { 전자상거래 } \\
\text { 플랫폼 }\end{array}$ & $\begin{array}{l}\text { 무인상점·지능형 자동 판매기·무인 수거회수 처리 시스템 등 지능형 판매 장치의 고도화 } \\
\text { 와 전자상거래 라이브방송·소셜 커머스.커뮤니티 전자상거래 등 지능형 온라인 영업판매 } \\
\text { 의 신영역을 적극 개척 }\end{array}$ \\
\hline 8 & 비접촉 배송 & $\begin{array}{l}\text { 소매·의료·요식업 등 업체의 무인 배송을 추진하고 콜드체인·빠른 배송·야간 배송의 촉진 } \\
\text { 을 지원하며, 무인 수송수단의 발전을 보장 }\end{array}$ \\
\hline 9 & $\begin{array}{l}\text { 새로운 외부 } \\
\text { 이동방식 }\end{array}$ & $\begin{array}{l}\text { 지능형 커넥티드 차량의 상업화 추진, 시간당 렌트가 가능한 공유 자동차의 발전을 지원 } \\
\text { 하며 자동제어 택시를 연구개발 하는 등 새로운 이동 방식을 개발해 스마트한 이동 서비 } \\
\text { 스체인을 구축 }\end{array}$ \\
\hline 10 & 온라인 교육 & $\begin{array}{l}\text { '상하이온라인학교(上海微校)', '온라인 교육(空中课堂)' 등 새로운 교육 트렌드를 활성 } \\
\text { 화시키며, '학점은행(学分银行)'를 개발해 시민의 평생교육을 지원하는 등 디지털화된 } \\
\text { 교육시스템을 구축 }\end{array}$ \\
\hline 11 & $\begin{array}{l}\text { 디자인 } \\
\text { 설계의 } \\
\text { 온라인 화 }\end{array}$ & $\begin{array}{l}\text { 맞춤형 온라인 디자인 설계 분야를 발전시키고 개성화된 디자인 설계와 창의적인 인터랙 } \\
\text { 션 디자인, 사용자가 함께 참여 가능한 대중 디자인 설계(ㅅㅆㅇㅔ, ㅅㅆ븝, ㅅㅆㄹ, 식) 그의 의 } \\
\text { 온라인 창작활동을 지원 }\end{array}$ \\
\hline 12 & 온라인 의료 & $\begin{array}{l}\text { 인터넷 온라인 병원을 개설하고 의료보험의 이동식 지불방식의 시범 및 보급, } 5 \mathrm{G} \text { 기술 } \\
\text { 에 기초한 원격 진료와 수술의 촉진, 질병진단과 약물 연구개발 등 의료 분야에서의 Al } \\
\text { 활용 추진 등 }\end{array}$ \\
\hline
\end{tabular}

출처: 상하이시 인민정부(KOTRA 상하이 무역관 재가공) 


\section{다. 대만152)}

1) 해외주재기관 예술 문화 공연과 전시 활동 교류

대만은 해외 문화 거점 증설에 적극적인데, 해외 주재기관도 대만 문화를 보여주는 창 역할을 할 수 있다고 생각한다. 대만의 해외주재기관이 요충지에 위치하여, 관련 자 원협조와 중개매체의 역할을 담당하고, 문화거점을 대만문화 창구로 만들며, 나아가 타 국 정부, 민간조직과 국민과의 상호작용과 소통을 심화시킬 수 있기 때문이다.

공연과 전시 예술 활동의 교류에 있어서 주로 문화부를 중심으로 13 개 해외주재기관 의 문화예술 행사 진행이 있었다. 행사 진행 횟수 면에서 해외주재기관의 공연예술 활동 에 관해서는, 2019년 총 322회를 개최하였으며, 연인원은 98,759명이었다. 그 중 주프 랑스 대만문화센터가 95회로 가장 많은 행사를 진행했고, 홍콩 광화신문문화센터가 38,678 명으로 가장 많은 인원과 교류하였다. 한편, 해외주재기관의 전시예술행사의 경 우 2019년 총 234회 개최했고, 2,229,752명이 참여하였다. 이 중 주뉴욕 대만문화센터 가 55회로 가장 많은 행사를 개최했고, 주일본대표부 대만문화센터 824,262명으로 가 장 참여가 많았으며, 기타 문화예술행사에서는 총 527 회 개최해, 128,123 명이 참여하 였다. 2020년 대만은 인도 뉴델리와 호주 시드니, 이탈리아 로마 등에 새로운 거점을 증설해 해외 문화 거점을 16 곳으로 늘렸다. 이처럼 주둔지 및 관할지역에서 대만의 특색 있는 문화 활동을 지속적으로 추진하고 있으며, 또한 주미 대표부의 대만서원은 2020년 12월 트윈오크스(雙橡園)에서《섬에서 오다-고산, 토지, 바다(從島上來 - 高山、土地大 海)》라는 특별전시회를 기획하여 수행는데, 이는 현대 예술가들의 작품을 통해 대만의 인문적 풍경을 국제 관객들에게 소개하고자 하였다.

\section{2) 문학: 국내외 작가와 출판업자의 국제 교류 참여 지원}

1987년부터 매년 열렸던 대만국제도서전은 2020년 2월 4일 2월 9일 열릴 예정이었

152) 대만 현황은 아래의 자료를 활용하여 조합하여 작성하였음. 2020 臺灣文化創意産業發展年報』臺北: 文化內容策進院, 2021; 『國家文化藝術基金會 2020年報』臺北: 國家文化藝術基金會, 2021; 『文化部 內容策進院年度報告 2019-2020』臺北: 文化內容策進院, 2021; 『文化部文化資産局年報2020』臺中: 文化部文化資産局, 2021; 『文化統系 2020』臺北: 文化部, 2020; 대만 문화부 사이트 https://mww. moc.gov.tw; 각종 영화제, 음악제 사이트; 蔡淳任, “疫後重生的文化環境與挑戰: 2020年文化政策觀 察”（藝術家2021年1月548期; http://artist-magazine.com/edcontent_d.php?lang=tw\&tb=8\&id $=13341$ 
으나, 코로나로 인해 5월 7일 5월 12일로 연기되었으나, 2020년 3월 18 일 문화부가 타이베이 도서전 재단과 공동으로 도서전 취소를 결정하였다. 올해 대만국제도서전은 정 상적으로 진행되지 못하였다. 온라인 도서전 및 출판 전문 포럼으로 변경, 진행하였다. 출판업자는 온라인 도서전을 통해 올해의 신간 및 독자 경험을 널리 보급했고, 프랑크푸 르트 출판 인재 양성과정, 서양어 출판 심포지엄, 출판역량, 아동서적, 오디오북 등 다양 한 국제협력 출판 전문 포럼을 진행하고 있다. 이 밖에 방역 규범에 부합하는 전제에 따라 작은 규모의 도서 전람회를 개최한다. 예를 들어 '말과 나의 동행(語我同行) - 다국 어와 민족 간 대화(多元語言與族群對話)'과 같은 작은 도서전이 2021년 1월 26일부터 31 일까지 90 회의 다국어로봇 안내, 26 회의 짧은 강의(동시 인터넷 생중계), 13 곳의 출 판 동업 도서 전시장 등에서 열려 실제 3,931 명이 참여하고, 28,191 명이 인터넷으로 시청하였다. 또 2011년 2월 26일부터 3월 1일까지 국립역사박물관 남문단지에서 '옛날 이야기·박물관'이라는 타이틀의 전시를 개최하여 참가자들이 '예술, '역사', '인권'의 3 부스에서 박물관의 다양한 관점을 접할 수 있도록 하였다.

또한 대만 문화부는 대만 문학의 해외 보급과 수출을 돕기 위해 2020년 총 46건의 번역출판 지원이 이뤼져, 白先勇의 〈타이베이 사람(臺北人)〉, 러시아어 판, 幸佳慧의 〈나 비송이(蝴蝶朵朵)의 태국어 판, 黃春明의 소설집의 일본어 판, 邱妙津의 〈악어수기〉의 베 트남어 판, 吳明益의 〈복안을 가진 사람(複眼人)의 카탈루냐어 판, 三毛의 〈사하라의 세 월>의 우크라이나어 판 등 17 종을 번역 완료하였다. 국립대만문학관은 해외 출판사, 대 학과의 협업을 통해 체계적인 수출 및 대만 문학 브랜드 설립을 추진하고 있다. '대만 문학을 각국 대학으로 촉진하기 위한 전반기 연구 계획도모(推動臺灣文學到各國大學前期 研究㖕畫)'는 미국, 일본, 한국, 영국, 프랑스, 독일, 체코, 이탈리아, 스페인, 네덜란드 등 10 여 개국이 각국 대학 문학 수업의 중점 방향을 평가하여 현지 교육 수요에 부합하 는 독본을 후속 제공하기 위해 추진되고 있다.

3) 영화: 대만 영화의 국제 영화제 참가

대만은 국산 장편 영화 제작을 보조금으로 지원하고, 다원적 영화 생산제를 구동하고 있으며, 대만 콘텐츠 브랜드 국제 평판을 높이고자 하고 있다. 국제 교류를 위해 대만은 대만의 해외 영화 전람회 활동 참여와 국제영화제 출품을 지속해 오고 있는데, 2019년 
에는 출품 367편, 국제영화제 선정작 76편, 국제영화제 수상작 8편, 국제영화시장 참여 지원 183 편, 정부 지원 국제영화제 참가 인원 113 명이다. 2020년에는 대만 영화가 국 제시장에 379편이 참가하여 41개 영화가 국제영화제에서 입선했고, 12 편이 국제영화제 상을 획득했다. 특히 129 편의 영화가 국제영화시장에 참여에 문화부의 도움을 받았고, 국제영화제 참가 인원은 15 명이 지원을 받았다.

\section{라. 베트남}

\section{1) 코로나로 인한 문화분야 피해}

코로나 19로 인해 베트남 정부에서도 '사회적 거리두기' 일환으로 사람들이 모이는 것을 금지하면서 문화축제행사에도 많이 축소되었다. 베트남 내 규모가 큰 축제 중 하 나인 '호치민시 아오자이 축제 2020'는 3월에 개최 예정이었지만, 코로나 19로 인해 4 월로 잠정 연기되었었다. 매년 다낭에서 개최되는 '다낭 국제 불꽃 축제'는 베트남 사람 들뿐만 아니라, 외국인 관광객들도 많이 찾는 세계적인 불꽃축제이지만, 취소되었다. 베 트남 전통축제 중 가장 큰 행사로 손꼽히는 흥붕(Hung Vuong) 왕 기념 축제는 규모가 축소 운영되었다. 2021년 행사는 대폭 축소하여 개최하였다. 이처럼 같은 축제 성격의 행사라도 그 대응에 있어 차이가 발생하였다.

\section{2) 온라인 캠페인 진행}

베트남 정부의 보건부와 유니세프가 공동으로 온라인 콘서트 형식의 〈행복한 집〉이라 는 캠페인을 2020년 4월 2일부터 진행하였다. 〈행복한 집> 캠페인은 사회적 거리두기 운동시행으로 집에만 머물고 있는 사람들에게 코로나19로 지친 심신을 위로하고 달래주 기 위하여 긍정적인 메시지를 전파하고, 사회적 상호 작용을 제한하며 코로나 19 를 방지 하기 위해 모임을 제한하는 것을 목표로 시작되었다. 캠페인에 동참한 베트남 음악예술 가들은 소셜미디어에서 피아노 연주회, 무용 공연, 노래 등 다양한 장르의 온라인 콘서 트를 진행하며, 자신의 음악 팬들과 대중들에게 음악을 선물하고 격려 메시지를 전함으 로써 코로나19의 극복 의지를 높이고, 동참하는 국민들을 응원하고 있다.153)

153) 출처: 한국국제문화교류진흥원 통신원 리포트(http://kofice.or.kr/c30correspondent/c30_correspo ndent_02_view.asp?seq=18383\&page=3\&find=\&search=\&search2=\%EB\%B2\%A0\%ED\%8 


\section{라. 호주}

1) 호주 예술위원회, 국제문화교류 사업 지원 지속

호주는 현재 코로나 19 상황으로 인하여 국제문화교류 관련 프로그램인 International Arts Strategy Outcomes Fund, International Residencies Program 과 국제 시장 과 플랫폼 참여 지원(support to attend international markets and platforms)에 대한 참여가 불가능한 상황이다. 하지만, 호주는 개별 예술가들과 문화단체들이 예술 프 로젝트 카테고리의 지원 사업을 통해 국제문화교류 사업을 할 수 있도록 하고 있다. 대 신 물리적 이동이 어려운 상황에서, 디지털 기술과 비대면 방식을 활용한 국제문화교류 활동을 지속하는 것을 권장하고 있다.

그리고 위원회 차원에서 국제예술전략(2015-2020)을 준비하여, 기후변화, 환경변화, 포스트 코로나 상황 등을 대비한 국제예술활동 지원에 대한 논의를 정리하고 있다. ${ }^{154)}$

\section{2) 디지털 콘텐츠 이용 활성화 위한 저작권법 개정 착수}

호주 연방정부 인프라·교통·지역개발·커뮤니케이션부(Department of Infrastructure, Transport, Regional Development and Communication)는 2020년 8월 코로나 19 로 교육문화 기관이 온라인 서비스를 제공하는 데 있어 필요한 디지털 콘텐츠 이용 활성화를 위해 저작권법 개정을 추진하겠다고 발표했다. 호주 정부는 1968년 제정된 저 작권법(Copyright Act1968)을 개정하기 위해, 2년간 다양한 이해관계자의 자문을 구 하고 생산성위원회의 2016년 지적재산권 보고서 내 저작권 개선안에 해당하는 내용을 참고해 개정안을 준비 중이다. 개정안의 핵심 내용은 (1) 공연저작물에 대한 유한책임 (limited liability)모델 도입 (2) 비상업 저작물 인용에 있어 새로운 공정이용(fair dealing) 예외 도입 (3) 도서관과 아카이브를 위한 저작권 예외 규정 간소화 (4) 교육 목적 저작권 예외 규정 간소화 (5) 법정허락제도(the government statutory licensing scheme) 개선 등이다. 개정안은 디지털 콘텐츠 활용에 있어 제약요건을 완화하는 것을 목적으로 한다.155)

$\mathrm{A} \% \mathrm{~B} 8 \% \mathrm{~EB} \% 82 \% \mathrm{~A} 8$ ) 검색일 2021년 8월 25일

154) 출처: 호주 예술위원회(https://australiacouncil.gov.au/investment-and-development/internati onal-announcement/) 검색일 2021년 8월 24일

155) 출처: 호주 연방정부 인프라·교통·지역개발·커뮤니케이션부(Department of Infrastructure, Transport, 


\section{4. 국제기구}

\section{가. 국제문화예술위원회및문화진흥원연맹(IFACCA)}

1) 디지털 시대의 문화예술지원 보고서 발간

IFACCA156)는 2020년 4월 23일 '디지털 시대의 문화예술지원(Supporting Culture in the Digital Age)'보고서를 발간하였다. 코로나바이러스 위기 속에서 생긴 디지털화 에 대한 기회와 해결해야 할 과제(사회기반시설에 대한 상이한 접근성, 기존에 있던 사 회적 차별 재생산, 지적재산의 보호, 문화적 표현의 다양성 보장, 디지털 청중에 대한 이해 등)를 주요 주제로 다루고 있다. 보고서는 문화적 가치 사슬과 업계 종사자, 더 넓 게는 전체 문화 생태계를 위해 더욱 잘 정비된 전략을 개발해야 할 필요성을 제시한다. 본문에는 디지털 문화계획 시 고려해야 할 사항과 공공기관의 문화 지원 방식에 대한 서술이 포함되어 있다. 예를 들어, 캐나다 예술위원회는 디지털 시대에 문화를 지원하기 위해 2017년 디지털 기술과 관련된 사회적 문제를 이해하고 디지털에 대한 접근성을 향상시키기 위해 '디지털 전략기금’을 설립했다. 많은 공공기관은 예술가와 문화단체가 새로운 기술에 적응하는 데 도움을 주는 훈련과 자원을 제공하는데 중요한 역할을 하며, 이는 종종 문화 분야를 넘어서는 파트너십을 통해 이루어진다. 영국 예술위원회가 디지 털 콘텐츠 제작, 웹 디자인, 검색 엔진 최적화, 마케팅, 전자상거래, $\mathrm{CRM}$, 디지털 데이 터 분석 분야에 전문적인 지식을 갖춘 9명의 전문가로 구성된 '디지털 문화 네트워크 (Digital Culture Network)'를 구축한 경우가 그 사례이다.157)

\section{2) 문화정책의 현재 중요 이슈}

IFACCA는 홈페이지에서 코로나 상황이 지속되는 속에서 문화정책의 현재 주목받는 이슈에 대하여 정리해놓았다. 관련 이슈로는 기술과 디지털화, 지속가능발전, 인권, 기후

Regional Development and Communication) 홈페이지

https://www.communications.gov.au/departmental-news/copyright-access-reforms 검색일 - 2021년 5월 20일

156) 국제문화예술위원회및문화진흥원연맹(IFACCA)는 70 여개국의 예술위원회, 문화부, 문화와 예술 진흥 정 부기구들의 글로벌 네트워크 이다. 2001년 창립하였고, 세계 70 개국 문화예술위원회, 문화예술진흥원 및 문화예술분야 전문기관이다.

157) 출처: https://ifacca.org/what-we-do/knowledge-evidence-insight/acorns/acorns-399-ne w-report-supporting-culture-digital-a/ 검색일 - 2021년 5월 20일 
변화 등이 주요 토픽으로 정리되어 있다. 전세계적으로 문화정책영역에서도 디지털화와 새로운 미디어 기술의 적용에 대한 검토와 관련 프로그램들이 많이 진행되고 있다는 것 을 알수 있다. 두 번째, 문화정책 영역 또한 유엔의 지속가능목표의 달성에 기여할 수 있도록 하여야 한다는 것을 확인할 수 있다. 마지막으로, 문화권부터 예술적 표현의 자 유 등 문화적 권리 또한 인권의 중요한 부분임을 강조하고 있다.158)

\section{나. 국제연합교육과학문화기구(United Nations Educational, Scientific and Cultural Organization, UNESCO)}

1) Share Our Heritage 캠페인

UNESCO는 4월부터 \#ShareOurHeritage 라는 해시태그를 통해 비디오와 가상방문 을 공유하는 캠페인을 진행하였다. 159) 4월 15일부터 6월 24일까지 문화분야의 코로나 19 영향의 핵심적인 내용을 "Culture \& Covid-19 : Impact \& Response Tracker" 라는 정기리포트를 통해 국가, 지역, 지방차원의 전세계적인 대응과 현황을 정리하여 11 개 이슈를 발행하였다. ${ }^{160)}$

2) 문화 간 대화(Intercultural dialogue, ICD) 보고서 발간

문화간 대화보고서(ICD)는 유네스코, 유럽회의와 같은 국제 및 정부 기관에서 도입된 이후로 '사회적 결속, 집단간 연대, 문화간 이해'의 의제를 진전시키기 위한 방법으로 채택되어 왔다. ICD 전문가들과 관련 기관은 코로나 위기 상황에 빠르게 적응했으며, 전염병의 부정적 영향을 완화하기 위해 대부분의 활동을 온라인으로 전환했다. 이러한 변화는 ICD 접근법의 핵심 영역인 교차 문화 교류, 상호 지원 및 집단 간 연대가 온라인 으로 안전하게 유지될 수 있도록 보장했으며, COVID-19에 대한 사회문화적 대응에서 핵심적인 역할을 계속 수행할 수 있도록 했다. ICD 의제가 추진되고 있는 새로운 맥락 에 집중하여 전 세계적 유행병의 사회문화적 영향에 대한 기존의 많은 정량적 분석을

158) 출처: https://ifacca.org/themes/current-issues-cultural-policy/ 검색일 - 2021년 8월 24일

159) 유네스코 홈페이지(https://en.unesco.org/news/culture-covid-19-impact-and-response-tracker) 검색일 2021년 3월 3일

160) 유네스코 홈페이지(https://en.unesco.org/news/culture-covid-19-impact-and-response-tracker) 검색일 2021년 3월 3일 
보완하는 것을 목적으로 한다. 이를 통해 다음과 같은 4 가지 핵심 목표가 추진되고 있다.

(1) ICD 및 지역사회 관계에 대한 COVID-19 영향 탐구

(2) 코로나 19 로 인한 새로운 문제와 온라인 ICD 계획에 대한 지역사회의 창의적인 대응 방안 검토

(3) 효과적인 정책 대응 방안의 설계 및 구현을 위한 핵심 원칙 식별

(4) 팬데믹으로 영향을 받은 문화간 관계와 연대를 지원하고 더욱 개선하기 위해 ICD 가 코로나 이후 상황에 의미 있는 기여를 할 수 있는 가능성에 대한 초기 성찰

유네스코의 최신 발표에 의하면, 전염병의 경제적 영향은 현재 경제적 혼란을 처리할 준비가 잘 되어 있지 않은 남부 국가(countries in the Global South)에서 더욱 심각하 게 느껴진다고 주장하였다.161) 이는 세계가 그 어느 때보다도 유엔의 지속가능개발목표 (Sustainable Development Goals, SDG)를 놓쳐서는 안 된다는 것을 보여준다. 따라 서 국제적으로 광범위한 개발 격차를 해소하는 데 중점을 두고 더 광범위한 SDG 의제에 서 코로나 19에 대한 대응을 분리하지 않는 것이 중요하다. 또한 특정 SDG와 연계된 분야(예: SDG 3 보건, SDG 4 교육)에서 그 영향이 심각하게 감지되고 있지만, 다른 모든 SDG가 코로나 19 팬데믹으로 인해 부정적인 영향을 받아왔고 앞으로도 계속 받을 것이다. 유네스코는 기존의 불평등이 더 이상 악화되지 않고 SDG 달성을 위한 포괄적인 진전이 유지되도록 하기 위해서는, 정부, 국제기구, 시민사회 및 민간 부문의 모든 이해 관계자가 소외된 지역사회 간의 연대를 육성하고 유지하는데 전념해야 할 것이라고 보 고하였다. 실제로, 집단 간 연대, 문화 간 협력, 그리고 이해의 중요성은 UN 사무총장의 보고서와 유행병에 대한 전 세계적인 대응을 이끌어내기 위한 메시지에서 강조되어 왔 다. 여기에는 사무총장의 세계 휴전 요구, 코로나 19 및 인권에 대한 UN 보고서, 코로나 19 가 여성에게 미치는 영향에 대한 정책 개요, 그리고 코로나 19 의 즉각적인 사회-경제 적 영향을 관리하기 위한 $\mathrm{UN}$ 체제 등이 포함된다.

유네스코는 특히 코로나 19가 비 시민(non-citizens)에 대한 차별이 증가하는 점을 우려하고 있는데, 현대 생활의 모든 면과 사람들에게 영향을 미치고 있는데, 확실한 것은 불안정한 시민권 지위를 가진 사람들, 특히 이주 노동자, 난민, 유학생들이 팬데믹으로

161) 유네스코, 2020. The socio-cultural impact of COVID-19 
인해 더 심각한 차별을 경험했다는 것이다. 코로나와 관련된 인종차별적 담론의 사례가 발생하고 있다. 이에 더욱 문화 간 교류와 협력 증대가 요구되고 있는데, (1) 다문화, 집단 간 연대 촉진 (2) 문화간 학습에 대한 창조적 예술 기반 접근 등의 방법을 제시하였다. 특히 이동에 대한 법적인 제한과 사회적 거리 두기에 대한 강조를 감안할 때, 대화와 다문화의 많은 형태, 집단 간 연대가 온라인 공간으로 옮겨지고 있으며, 매우 다양한 형태 로 이루어지고 있음을 알 수 있었다. 인터넷과 온라인 소셜 미디어 플랫폼은 코로나 기간 동안 연대와 지지 메시지를 확산시키는 데 널리 사용되었는데, 문화 간 연대의 대표적인 사례로 나이지리아 젊은이들이 '언어와 종교 간 행사를 통한 평화 증진(Promoting Peace through Languages and Interfaith Events)'을 목표로 가상 대화 시리즈를 개최한 것을 들 수 있다162). 이러한 온라인 학습 행사는 평화 구축 계획에 참여하는데 필요한 언어 및 다문화 도구를 습득하기 위해 나이지리아 젊은이들의 기술을 지속적으로 개발하는 것을 목표로 한다. 코로나 19 팬데믹 기간 동안 종교간 연대 정신을 높이기 위해, 'NGO Religions for Peace'와 세계 각국의 저명한 종교지도자들이 페이스북을 통해 '희망과 연대를 위하여(for hope and solidarity)' 종교 간 교류를 진행했다. 13 개 의 다른 신앙 전통에서 온 종교 지도자들이 참가했다. 이번 교류는 코로나 시대에 기도와 행동을 함께 하자는 종교 간 약속으로 큰 의미가 있다고 볼 수 있다.163)

[그림 3-6] 유네스코 문화 간 대화 소개 페이지

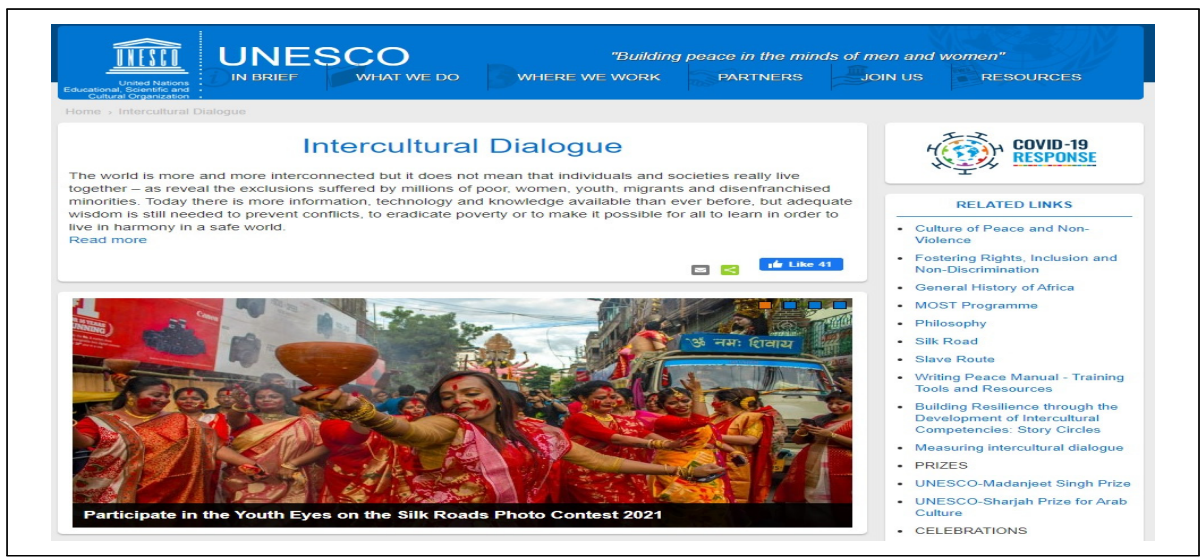

162) https://www.kaiciid.org/news-events/features/young-people-launch-virtual-peacebuildin g-project-nigeria

163) https://english.alarabiya.net/features/2020/04/02/Inspiring-interfaith-moments-during-th e-coronavirus-pandemic 
코로나 19 팬데믹 동안 문화 교류는 대부분 온라인을 통해 많이 진행되었는데, 온라 인 공간은 또한 취약하거나 소외된 공동체에 필요한 자원을 만들기 위한 문화 간 협업을 촉진하기 위해 널리 사용될 수 있다는 큰 장점이 있다. Yadesa Bojia 같은 예술가들은 '에티오피아계 미국인들을 위한 공식 코로나 바이러스 조언(produced facebook videos translating official coronavirus advice for Ethiopian Americans)'을 번 역한 페이스북 동영상을 제작하여 널리 전파시켰다. 남아프리카 공화국에서도 Ndlovu 청소년 합창단은 주요 미디어 매체에 접할 수 없는 지역사회에 세계보건기구의 코로나 예방 조언을 전파하기 위해 공연 때 '공황상태에서 벗어나라: 우리는 이겨낼 수 있다(the 'Don't panic: We've got this)' 동영상을 제작하여 페이스북에 게시하는 등 소셜 네트 워크는 온라인상의 국제문화교류의 핵심 매개체로 널리 사용되고 있다.

유네스코는 또한 많은 예술 단체들이 문화 간 학습을 지원하고 위기 동안 사회적 연결 성을 유지하기 위해 온라인상에서 수집품과 공연을 전시할 수 있는 창의적인 수단을 찾 는 등, 예술과 예술 공연은 코로나 19 기간 동안 사람들을 연결하는 데 중요한 역할을 해왔다고 소개했다.164) 상파울루 미술관, 상트페테르부르크에 있는 에르미타주 박물관, 파리의 루브르 박물관 등 많은 박물관들이 방문객들 위해 온라인으로 전시와 소장품을 구경할 수 있도록 온라인을 활용했다. 이러한 온라인 전시회는 국가 내외의 서로 다른 국가 및 문화적 배경을 가진 사람들을 대상으로 진행되는 문화 간 학습을 위한 새로운 수단을 창출하는 수단으로 활용되고 있다. 온라인 플랫폼은 또한 예술 단체에서 문화 간 이해와 사회적 화합을 촉진하기 위해 사용되어 왔다. 예를 들어, 파키스탄 Ajoka 극 장은 개인과 지역사회를 위한 유산과 문화적 정체성의 중요성을 강조하는 'Coronlogue 온라인 연극제'를 개최하였다. 이와 유사하게, 온라인 마스터 클래스를 통해 세대 간 지 식 공유를 지속하기 위해서 '터키의 전통 도자기, 에콰도르의 모자 짜기, 그리스의 전통 무용, 우크라이나의 옷감 만들기, 키르기스스탄의 펠트 카펫 만들기' 등 많은 국제문화 교류 활동이 진행되었다.

164) 유네스코, 2020. The socio-cultural impact of COVID-19 


\section{다. 유럽 문화경영 및 정책 네트워크(ENCATC)}

1) 'Creative \#StayHome Pack'

ENCATC165)은 코로나19 시대에 대응함에 있어 관련 정보와 지식을 모아 제공하는 역을 하고 있다. 유럽을 중심으로 활동하는 문화예술전문가, 연구자, 현장인력의 경험과 지성을 모아 코로나 19 에 대한 이해와 파급력, 위기상황에 대한 정보와 지식을 축적하고 공유하는 싱크탱크의 기능을 수행하고 있다. ENCATC는 'Creative \#StayHome Pack' 을 신설하여 매주 주기적으로 코로나19로 인해 발생한 여러 문화예술활동의 어려운 환 경에 대해 대응책을 공유하는 온라인 공간을 마련하였음. 해당 페이지에서는 유럽 밖 여러 나라의 문화예술계 대응방안을 조사하여 공유하기도 하며, 자원하는 경우 개인이 관련 자료와 정보를 공유할 수도 있도록 하였다.166)

\section{2) 2021 ENCATC 디지털 회의167)}

ENCATC 디지털 콩그레스(ENCATC Digital Congress)는 문화 경영과 정책에 대한 이론, 교육, 연구 및 실천의 발전을 위한 유일한 글로벌 행사이다. 매년 문화경영 및 정 책교육 분야의 학계, 트레이너, 연구자, 문화전문가, 정책입안자, 예술가, 학생 등이 참 여한다. 2021년 코로나 19로 인해 온라인에서 진행되며, 10월 19일 제2회 ENCATC 펠로우십 어워드인 키노트 스피치로 시작된다. 2021년 ENCATC 디지털 컨퍼런스의 주 제는 “각광받는 예술가들!"이다. 문화경영과 정책분야의 새로운 교육과 연구 의제를 모 색하기 위해 2021년 10월 19일부터 22일까지 온라인으로 개최된다. 다음 날에는 글로 벌 컨베이션스(Global Conversations), EU 라운드 테이블(Round Table), 청년 및 신 흥 연구자 포럼(Young and Emerging Researchers' Forum), 연례 교육 및 연구 세 션(Engual Education and Research Session)도 포함된다. 10월 22일 ENCATC연구 상 시상식(ENCATC Fellowship Award)을 끝으로 막을 내린다. 문화 관리 및 정책 교 육자 및 연구자의 네트워크로서, 2021년 ENCATC 디지털 콩그레스 프로그램을 통해

165) European Network on Cultural Management and Policy(ENCATC)는 비영리단체이자 유럽중심 문화예술경영정책분야 협력단체이다.

166) 출처: ENCATC 홈페이지(https://www.encatc.org/en/news/encatc-in-times-of-covid-19/) 검색일 2021년 3월 3일

167) https://uww.encatccongress.org/\#about(검색일 2021/08/26) 
문화예술 및 창작 분야의 핵심 요소로서의 아티스트의 작업을 인정하는 것은 다음의 목 표를 가진다.

- 교육 및 연구뿐만 아니라 문화경영 및 정책이 예술인의 상황에 미치는 영향에 대한 성찰의 공간 제공

- 보건 위기뿐 아니라 기후 변화, 사회적 변화 등과 같은 현재 상황의 다른 차원까지 고려한 문화 및 창조 부문의 지속 가능성에 대한 폭넓은 성찰을 촉진

- 전문화, 기준 등의 측면에서 예술가의 지위를 고려하는 것은 물론, 향후 시나리오에 서 예술인에게 부여된 역할과 영역 등에 대한 검토를 유도하는 문제에 대한 종합적 인 견해를 주도

- 아티스트의 니즈와 전략을 확대하는 것은 시기적절한 논의일 뿐만 아니라 매우 필 요한 논의이다. 예술가의 작품에 내재된 미학, 그리고 녹색 측면뿐만 아니라 원형 경제와 윤리적 차원까지 포함한 광범위한 지속가능성 개념은 New European Bauhaus의 두 기둥이며, 다양한 질문과 형식을 통해 논의될 대화의 핵심 측면이라 고 볼 수 있다.

\section{3) 포스트 코로나 19 싱크 탱크 문화(Think Tank Culture Post Covid-19)168)}

ENCATC는 코로나 19의 다양한 영향에 대한 더 나은 이해와 더 깊은 지식에 기여하 고자 하는 유럽 전역의 문화 및 교육 기관들이 참여하는 새로운 싱크탱크를 구상하였다. 싱크탱크는 다양한 전문가, 학계, 연구원, $\mathrm{EU}$ 문화 네트워크 및 대학의 대표들로 구성되 어 있다. 이들은 현재와 미래의 격동기에 문화 분야가 더 잘 탐색할 수 있도록 증거에 기초한 정책 권고안에 대한 강력한 조사 결과를 수집하고 분석하며 그에 대한 해결책을 마련하는 데 관심이 있다. 싱크탱크는 지속적으로 회의를 가지고 있으며, 두 달에 한번 씩 ENCATC 회원들에게 Post Covid-19 뉴스레터를 제공한다.

168) https://www.encatc.org/en/news/encatc-in-times-of-covid-19/think-tank-culture-postcovid-19/(검색일 2021/08/23) 


\section{라. 국제박물관협의회(ICOM)}

\section{1) 'Creative \#StayHome Pack'}

International Council of Museums(ICOM)은 "Covid-19 and museums. Impact, innovations and planning for post-crisis" 라는 주제로 박물관 관련하여 각 지역의 현황을 공유하고, 어떤 미래를 생각해야할 지에 대한 공개 세미나를 여는 등의 활동을 전개하고 있다. 뮤지엄 재개관에 대한 현황을 파악하고, 박물관들의 실태를 조사하는 등 의 조사활동도 진행하고 있다.169)

\section{2) 코로나와 박물관: 폐쇄 및 통행금지 시간에 의사소통하는 방법170)}

코로나 19는 문화를 통제하고 있다. 추후 통보가 있을 때까지 전 세계 많은 박물관들 이 문을 닫고 전시, 행사, 교육 프로그램 등이 취소되었다. 이러한 상황에서 여러 문화 공간이 문화 참여가 가능한 새로운 기회도 온라인에 제공하고 있으며, 많은 박물관이 온라인 서비스를 제공하고 있다. 온라인은 문화에 관심이 있는 사람들과 완전히 새로운 소통의 기회를 제공하고 박물관과 그들의 전시회에 가상으로 방문할 수 있는 기회를 제 공한다. 우피치 미술관의 페이스북 팔로워는 3만 1000 명이다. 조반니 보카치오의 '데카 메론'(1348-53)의 이름을 딴 \#uffizide 카메론 캠페인은 3월 10일부터 진행 중이다. 현 재 \#digitalmuseum 또는 \#DigSmus:와 같은 해시태그를 통해 많은 온라인 박물관 게 시물이 게시되고 있는데, 비엔나 벨베데레에서는 현재 디지털 관객들이 라이브 스트림을 통해 오후 3시에 벨베데레에서 작품을 안내받을 수 있다. Zentrum für Kunst und Medien(예술 및 미디어 센터) Karlsruhe 는 2021년 3월 21일 오후 4시 30분 인스타 그램 TV를 통해 전시 '미래사 쓰기' 온라인 가이드 투어를 제공한다. 뮌헨에 있는 독일 박물관은 다양한 소장품 부서의 3-D 투어를 진행하고 있다. Städel Museum Frankfurt am Main은 700년 예술 역사에서 가장 광범위한 디지털 컬렉션을 제공 중 에 있다. 소규모 박물관도 디지털 서비스를 진행 중인데, 보젠의 박물관은 대중들과 소 통하기 위해 \#텔레뮤지션(\#telemuseion)을 만들었다.

169) 출처: ICOM 홈페이지(https://icom.museum/en/covid-19/)검색일 2021년 3월 3일

170) http://avicom.mini.icom.museum/corona-and-museums/(검색일 2021/08/27) 
전 세계 박물관들은 코로나 시대에 대중들과 접촉을 유지하기 위해 "구글 아트 \& 컬 처” 포럼을 점점 더 많이 이용하고 있다. 최근 박물관들은 박물관은 많은 온라인 채널을 통해 가상 박물관 세계를 만들 수 있으며, 이는 그 어느 때보다도 더 긴밀한 대중과의 상호작용을 만들어낸다는 점에서 코로나19 팬데믹에서 배울 수 있는 좋은 기회를 가지 고 있다. 


\section{제3절 소 결}

제 3 장에서는 국내외 국제문화교류관련 정책동향을 살펴보았다. 문화체육관광부는 2018년 제1차 국제문화교류 진흥 종합계획을 수립하였고, 이를 근거로 국제문화교류 정책을 추진해왔다. '세계와 공감하고 협력하여 모두가 행복한 국제문화교류'라는 비전 아래 네가지 추진전략을 설정하였다. 하지만 코로나 19 이후 국제문화교류 사업 추진의 어려움이 발생하였고, 문화체육관광부는 2020년 12월 '제1차 국제문화교류 진흥 종합 계획(2018 2022)'을 개정하였다. 코로나 상황으로 인한 국제문화교류 정책 추진의 어 려움 속에서 새로운 방향을 모색하고 있다.

개별 국제문화교류 추진 공공기관들의 사업현황을 살펴보면, 전반적으로 사업이 중단 되기도 하였고, 비대면 방식으로 전환되어 사업이 그대로 추진되기도 하였다. 또한 다른 사업을 대체되어 사업이 추진되기도 하였다. 국제문화교류 수행기관들은 일정한 사업의 축소와 계획의 축소 경향이 드러나긴 하지만 전체적으로 사업의 계속 진행을 위해 여러 가지 사업 방식으로 모색하고 있었다.

국제동향을 살펴보면, 전반적으로 아직까지 코로나 상황에 대비한 전체적은 국제문화 교류 정책의 재정립을 추진하는 국가는 거의 없다. 대신 긴급 대응과 문화예술계 피해 구제 정책등이 주로 추진되고 있는 상황이다. 하지만, 그 중에서 몇몇 국가들은 의미있 는 정책을 추진하고 있기도 하다.

영국은 영국관광청이 주관하는 관광교역전인 트래블 마트(Explore GB)가 온라인으 로 진행되었다. 영국문화원 온라인 문화교류 프로그램으로 대화형 웨비나 프로그램인 위기 속의 문화: 글로벌 유산 관점 (Culture in Crisis: Global Heritage Perspectives) 을 개최하였고, 국제문화와 교육이 어려운 상황에서 세계 여러 나라의 생활과 문화에 대 해 온라인 영상을 제작하여 태그 \#CultureConnectsUs를 달아 SNS상에 배포하고 있다. 캐나다는 예술위원회가 Arts Abroad 펀드를 운영하고 있다. 이 펀드는 캐나다 예술 가들의 국제적 활동을 지원하기 위하여 조성되었다. 또한, 코로나 19 로 인한 여러 여행제 
한 조치와 행사 취소 등의 어려움 속에서도 캐나다 예술가들이 국제교류 활동을 지속하 도록 지원하고 있다. 호주도 개별 예술가들과 문화단체들이 예술 프로젝트 카테고리의 지원 사업을 통해 국제문화교류 사업을 할 수 있도록 하고 있다. 대신 물리적 이동이 어려운 상황에서, 디지털 기술과 비대면 방식을 활용한 국제문화교류 활동을 지속하는 것을 권장하고 있다.

프랑스는 사회적 거리두기 기간 중에도 문화예술 콘텐츠를 향유할 수 있도록 분아별 온라인 플랫폼을 운영 중이다. 각 기관마다 문화 향유층에 알맞은 콘텐츠를 맞춤 제공한 다. 프랑스 문화원(Institut français)은 18-25세 청년층의 프랑스어 학습을 장려하기 위해 \#plusloin 이라는 디지털 캠페인을 시작하였다. 이 캠페인은 웹 사이트, SNS, WhatsApp에서 액세스할 수 있는 전화번호로 이용할 수 있으며, 이로 인해 전 세계 젊 은이들이 프랑스어로 대화할 수 있게 하였다. 이 캠페인은 프랑스어를 공유한 인물들과 재능의 과정을 강조하며, 제인 버킨, 블랑카 리와 같이 많은 국제 영향력을 가진 젊은 사람들을 대상으로 프랑스어를 사용하는 재능 있는 사람들로 구성된 글로벌 커뮤니티를 만드는 것과 프랑스어로의 교류 증진을 위한 결합을 목표로 하고 있다. 프랑스 문화원은 코로나 상황을 극복하기 위하여 해외 각 프랑스 문화원들이 개발한 이니셔티브들을 공 유할 수 있도록 네트워크를 구성하여 운영하고 있다.

이탈리아는 이탈리아 문화에 비용을 지불하고 접근할 수 있는 온라인 플랫폼 구축을 위하여 1000 만 유로의 예산을 배정하였다. 이 플랫폼은 일명 'Netflix of Italian culture' 로 불리었으며, 정식 명칭은 ITsART로 정해졌다. 이 플랫폼은 유료와 무료 콘 텐츠를 모두 운영하며, 이 플랫폼을 통하여 이탈리아 음악, 오페라, 연극, 영화, 다양한 박물관 소장품 등에 대한 접근이 이탈리아 국내뿐만 아니라, 해외에서도 가능하도록 하 는 것이 목적이다. 대체로 해외 대부분의 국가들은 국제문화교류 사업을 지속하기 위하 여 노력을 하고 있다.

전반적으로 국내의 국제문화교류 사업 수행기관들은 각자 기존의 국제문화교류 사업 을 꾸준히 진행하기 위해 노력하고 있고, 비대면 방식을 적극 활용하여 사업을 추진하고 있다. 해외에서도 주요 국가들은 현재 코로나로 인한 국내 문화 산업과 관련 분야의 위 기 대응을 위해 노력하면서 국제문화교류 사업 또한 지속적으로 추진하기 위하여 노력 하고 있다. 새롭게 디지털 기술을 활용한 비대면 사업을 추진하고, 네트워크 사업을 구 상하여 추진하기도 하고 있다. 

코로나19 이후 국제문화교류 활성화방안 연구

제4장

전문가 설문조사 



\section{제1절 설문조사 개요}

\section{1. 조사목적}

1) 코로나19 시대 국제문화교류 인식 확인

2020년은 코로나19로 인하여 기존에 진행해오던 국제문화교류 사업 진행에 많은 차 질이 발생하였다. 이러한 상황에서 국제문화교류 사업에 대한 전문가들의 인식을 조사하 여 향후 정책 방향 구성에 중요한 참고자료로 삼고자 한다.

2) 국제문화교류 인식에 대한 실증 자료 확보

코로나19로 인하여 기존의 사업체계와 사업 방식을 수정해야할지 모르는 상황이 발 생하였다. 따라서 국제문화교류 전문가들의 인식을 확인하고, 향후 국제문화교류 정책 구성에 중요한 기반이 되는 실무 전문가들의 인식을 실증자료로 확보함으로써 이후 정 책 구성에 중요한 참고자료로 활용하고자 한다.

3) 국제문화교류 사업 추진 방향 인식 확인

코로나 19 로 인하여 국제문화교류 사업의 방식과 새로운 기술의 접목 등에 대한 고민 이 필요한 시점이다. 2020년 코로나로 인하여 온라인 비대면 방식으로 전환되어 많은 사업들이 진행되었다. 향후 국제문화교류 사업 진행에 있어서 비대면 방식의 지속 활용 과 새로운 방식의 필요성에 대한 전문가들의 인식을 확인하고자 한다.

4) 비대면 방식의 국제문화교류 활성화를 위한 지원방안

코로나 상황이 쉽게 개선되지 않는 상황에서 온라인 비대면 방식의 여러 사업 진행 
방법에 따라 사업을 진행하는 과정에서 필요성이나 어려움을 느낀 사업 방안의 개선을 위한 법·제도 개선에 대한 의견을 확인하고자 한다.

5) 새로운 기술이 접목된 국제문화교류 사업 방식에 대한 아이디어 청취

코로나 상황이 일정하게 개선되더라도 코로나이후 경험한 비대면 방식의 지속적인 활 용은 전 세계적으로 확산될 것으로 보여진다. 이를 좀 더 보편적이고, 대중들의 사업 참 여에 더 적합하도록 새로운 기술을 활용한 여러 가지 국제문화교류 사업 방식을 고민할 필요가 있다. 이에 대한 전문가들의 의견을 청취하고자 한다.

\section{2. 조사방법}

\section{가. 조사방법}

1) 조사 대상

100 명의 문화체육관광부 소속 기관의 국제문화교류 담당 실무자들과 관련 전공 연구 자들을 대상으로 조사를 진행하였다.

\section{2) 조사 방법}

100 명의 응답자로 조사 결과를 정리하였으며, 구조화된 설문지를 활용하여 사전 작성 된 설문대상자들을 대상으로 온라인 및 비대면(Fax, e-mail 등) 조사를 진행했다. 조사 기간은 7월 8월 사이 한 달 동안 진행했다.

\section{나. 조사내용 및 응답자 특성}

1) 설문조사 항목 구성

전문가 설문조사 항목은 크게 3 개의 범주로 나뉜다. 첫째, 국제문화교류 현황에 대한 인식, 둘째, 국제문화교류 정책/사업에 대한 만족도, 셋째, 코로나 이후 국제문화교류 발 전 방향이다. 국제문화교류 현황에 대한 인식 부분은 코로나19 이후 국제문화교류 회복 
에 대한 기대 정도, 한국 외교정책 수행에 있어 국제문화교류의 중요성, 비대면 방식의 국제문화교류 사업 수행의 효과성 정도, 코로나 19 로 인한 국제문화교류 사업의 변동이 큰 국가, 코로나19 기간 내 온라인 교류사업 참여 정도로 구성되었다. 국제문화교류 정 책/사업에 대한 만족도 부분은 코로나19로 발생한 변화가 국제문화교류 사업에 미친 영 향, 국제문화교류 사업에 대한 정책·지원에 대한 만족도, 코로나 19 로 인한 정부의 국제 문화교류사업 지원에 대한 인식, 위기/재난상황 시 국제문화교류 사업 추진을 위한 정책 의 필요성으로 구성되었다. 코로나 이후 국제문화교류 발전 뱡향은 코로나19 이후 국제 문화교류 활성화를 위한 정책의 필요성, 코로나 19 이후 민간분야 국제문화교류 활동 활 성화를 위해 필요한 지원, 국제문화교류 관련 업무 수행·계획 시 온라인/비대면 콘텐츠 활용 의향, 코로나19 이후 온라인/비대면 콘텐츠 부상에 대한 전망 및 평가, 온라인/비 대면 콘텐츠 활성화를 위해 필요한 정책적 지원, '문화로' 활용 경험 정도 및 개선 방향 으로 구성되었다.

〈표 4-1〉 전문가 설문조사 항목 구성

\begin{tabular}{|c|c|}
\hline 범주 & 설문 항목 \\
\hline 국제문화교류 현황 & $\begin{array}{l}\text { - 코로나19 이후 국제문화교류 회복에 대한 기대 정도 } \\
\text { - 한국 외교정책 수행에 있어 국제문화교류의 중요성 } \\
\text { - 비대면 방식의 국제문화교류 사업 수행의 효과성 정도 } \\
\text { - 코로나19로 인한 국제문화교류 사업의 변동이 큰 국가 } \\
\text { - 코로나19 기간 내 온라인 교류사업 참여 정도 }\end{array}$ \\
\hline $\begin{array}{c}\text { 국제문화교류 정책/ } \\
\text { 사업 만족도 }\end{array}$ & $\begin{array}{l}\text { - 코로나19로 발생한 변화가 국제문화교류 사업에 미친 영향 } \\
\text { - 국제문화교류 사업에 대한 정책.지원에 대한 만족도 } \\
\text { - 코로나19로 인한 정부의 국제문화교류사업 지원에 대한 인식 } \\
\text { - 위기/재난상황시 국제문화교류 사업 추진을 위한 정책의 필요성 }\end{array}$ \\
\hline $\begin{array}{c}\text { 코로나 이후 국제문화교류 } \\
\text { 발전 방향 }\end{array}$ & $\begin{array}{l}\text { - 코로나19 이후 국제문화교류 활성화를 위한 정책의 필요성 } \\
\text { - 코로나19 이후 민간분야 국제문화교류 활동 활성화를 위해 필요한 지원 } \\
\text { - 국제문화교류 관련 업무 수행.계획시 온라인/비대면 콘텐츠 활용 의향 } \\
\text { - 코로나19 이후 온라인/비대면 콘텐츠 부상에 대한 전망 및 평가 } \\
\text { - 온라인/비대면 콘텐츠 활성화를 위해 필요한 정책적 지원 } \\
\text { - '문화로' 활용 경험 정도 및 개선 방향 }\end{array}$ \\
\hline
\end{tabular}

\section{2) 응답자 특성}

전체 응답자 100 명의 유형별 특성은 〈표 4-2〉와 같으며, 여성, 30대 이하 및 40대, 문화 또는 예술 분야 종사자의 비중이 높게 나타났다.171) 
〈표 4-2〉 응답자 특성

\begin{tabular}{|c|c|c|c|}
\hline & & \multicolumn{2}{|c|}{ 결과 } \\
\hline & & 사례수 & $\%$ \\
\hline \multicolumn{2}{|c|}{ 전체 } & $(100)$ & 100.0 \\
\hline \multirow{2}{*}{ 성별 } & 남성 & $(27)$ & 27.0 \\
\hline & 여성 & $(73)$ & 73.0 \\
\hline \multirow{4}{*}{ 연령 } & 30대 이하 & (64) & 64.0 \\
\hline & 40대 & $(25)$ & 25.0 \\
\hline & 50대 & (7) & 7.0 \\
\hline & 60 대 이상 & (4) & 4.0 \\
\hline \multirow{4}{*}{$\begin{array}{l}\text { 종사 } \\
\text { 분야 }\end{array}$} & 문화(콘텐츠, 교류 등) & (56) & 56.0 \\
\hline & 예술(콘텐츠, 교류 등) & (29) & 29.0 \\
\hline & 국제관계(공공외교) & (9) & 9.0 \\
\hline & 기타 & (6) & 6.0 \\
\hline \multirow{2}{*}{$\begin{array}{c}\text { 국제 } \\
\text { 문화교육회복예상 }\end{array}$} & 회복될것 & $(72)$ & 72.0 \\
\hline & 회복되지 못할 것 & (28) & 28.0 \\
\hline \multirow{2}{*}{$\begin{array}{c}\text { 비대면 } \\
\text { 방식 효과성 }\end{array}$} & 효과 있음 & (43) & 43.0 \\
\hline & 효과 없음 & (57) & 57.0 \\
\hline \multirow{3}{*}{ 향후 비대면 활용의향 } & 있음 & (94) & 94.0 \\
\hline & 없음 & (2) & 2.0 \\
\hline & 모름 & (4) & 4.0 \\
\hline
\end{tabular}

171) 관련 전문가 및 종사자를 대상으로 진행되는 설문조사로서 selection bias 문제가 존재함을 밝힌다. 


\section{제2절 설문조사 결과 분석}

\section{1. 국제문화교류 현황}

\section{가. 코로나19 이후 국제문화교류 회복에 대한 기대 정도}

코로나19 이후 국제문화교류가 회복될 수 있을 것이라고 기대하는지 물었다. 응답자 의 $72.0 \%$ 가 코로나 19 펜데믹이 진정된 이후 코로나 19 이전과 같은 국제문화교류의 회 복에 대해 긍정적인 기대를 보였다. 문화 분야에 종사하는 경우, 코로나 19 이후 국제문 화교류 회복 기대에 대해 $78.6 \%$ 의 긍정 응답을 보였다. 반면 예술 분야에 종사하는 경 우, 부정 응답이 $41.4 \%$ 로 나타나 적지 않은 비중을 보이기도 했다.

[그림 4-1] 코로나19 이후 국제문화교류 회복에 대한 기대 정도

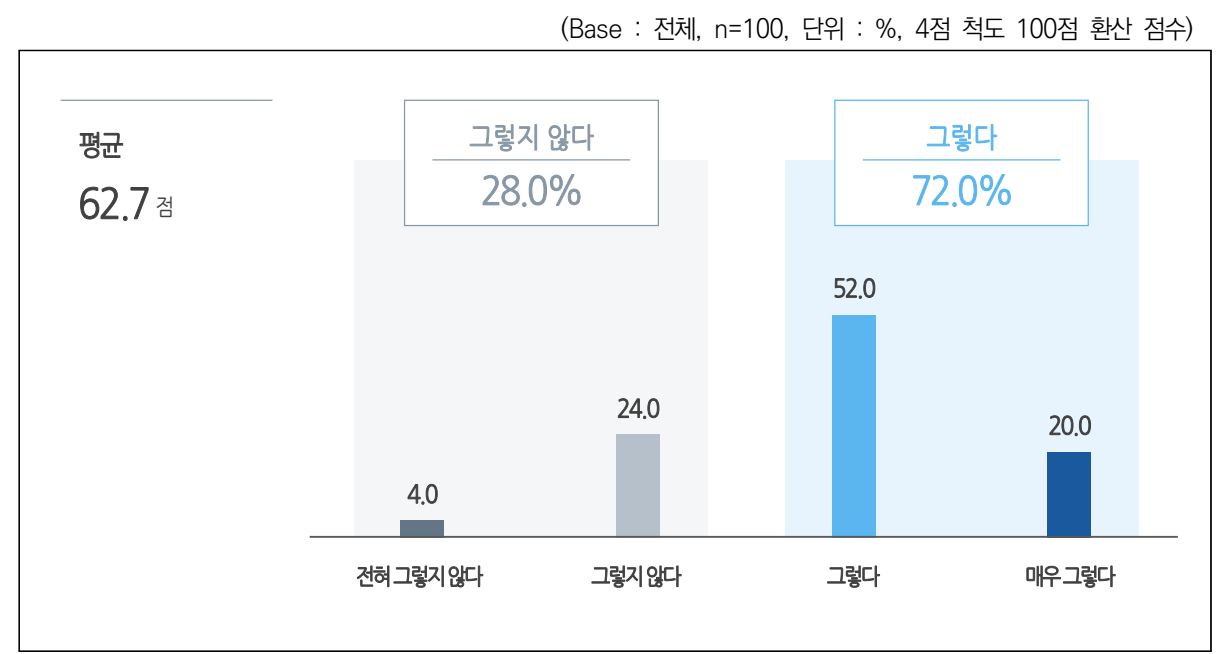




\section{나. 한국 외교정책 수행에 있어 국제문화교류의 중요성}

한국 외교정책 수행에 있어 국제문화교류의 중요성에 대하여 물었다. 대다수의 응답 자들은 한국이 외교정책을 수행하는 데에 있어 코로나 19 의 영향과 상관없이 국제문화교 류의 중요성을 높게 평가하고 있는 것으로 나타났다. 다만 코로나 19 팬데믹 기간 내에서 는 중요하다는 응답 비중이 83.0\%로, 팬데믹 이전 $97.0 \%$, 팬데믹 이후 $98.0 \%$ 에 비해서 는 낮았다. 특히, 코로나 극복 이후의 국제문화교류의 중요성에 대하여 대부분의 응답자 들이 긍정적으로 응답하였다. 특히 예술 분야 또는 국제관계 분야에 종사하는 경우, 코 로나19 기간 내 부정 응답이 각각 $31 \%, 33.3 \%$ 로 비교적 높게 나타났다. 코로나19 기간 내 사회적 거리두기 등으로 직접적인 접촉 자체가 어려워지면서, 국제문화교류 사업의 중요성에 대한 인식에도 영향을 미치는 것으로 보인다. 100점 만점의 환산 점수로 살펴 보았을 때, 코로나 19 이후 국제문화교류의 중요성에 대한 평균 점수는 86.0점으로, 코 로나19 기간 내 72.3점뿐만 아니라 코로나19 이전 78.0점보다도 높았다. 향후 코로나 19 팬데믹 상황에서 벗어나게 되었을 때, 코로나19 이전 수준 국제문화교류 사업 회복 을 바라는 응답자들의 인식이 반영된 것으로 보인다.

[그림 4-2] 한국 외교정책 수행에 있어 국제문화교류의 중요성

(Base : 전체, $\mathrm{n}=100$, 단위 : \%, 4점 척도 100점 환산 점수)

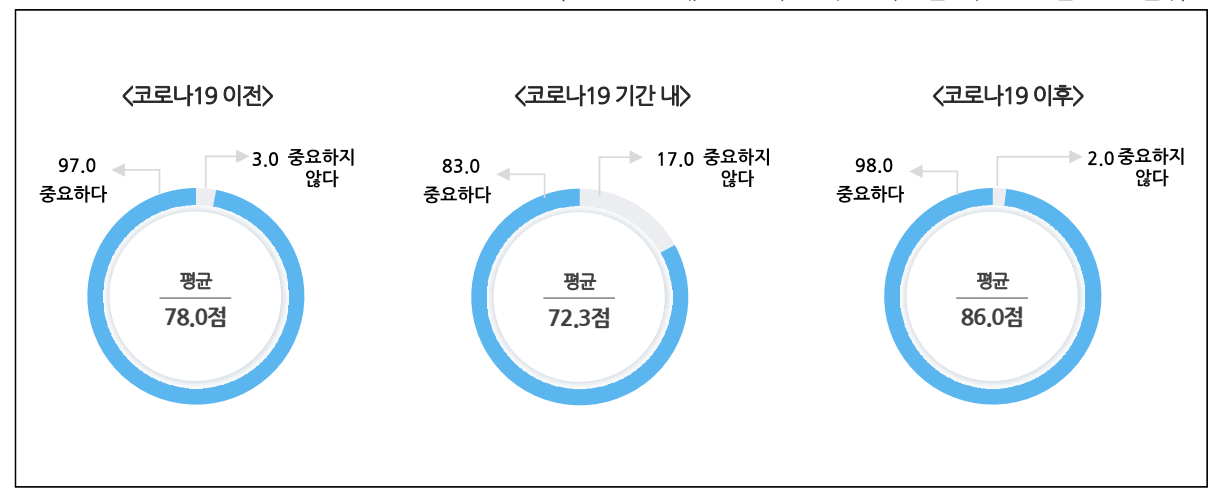




\section{다. 비대면 방식의 국제문화교류 사업 수행의 효과성 정도}

코로나19 펜데믹 이후 비대면 방식의 국제문화교류 사업이 증가함에 따라 비대면 방 식의 국제문화교류 사업 수행의 효과성을 측정한 결과, 비대면 방식의 사업 수행에 대해 효과가 있다는 응답이 $43.0 \%$ 로, 효과가 없다는 응답 $27.0 \%$ 에 비해 $16.0 \%$ 더 높게 평가 하고 있는 것으로 나타났다. 문화 분야에 종사하는 경우 효과가 있다는 응답이 $44.0 \%$ 로 나타난 반면, 예술 분야에 종사하는 경우 효과가 있다는 응답이 $37.9 \%$ 로 나타나 상대적 으로 긍정적인 평가 정도가 낮은 것으로 나타났다. 한편 국제관계 분야에 종사하는 경우, 효과가 없다는 응답이 $44.4 \%$ 로 효과가 있다는 응답 $33.3 \%$ 에 비해 더 높게 나타났다. 다만 사례수가 적어 해석에 유의할 필요가 있다.

[그림 4-3] 비대면 방식의 국제문화교류 사업 수행의 효과성 정도

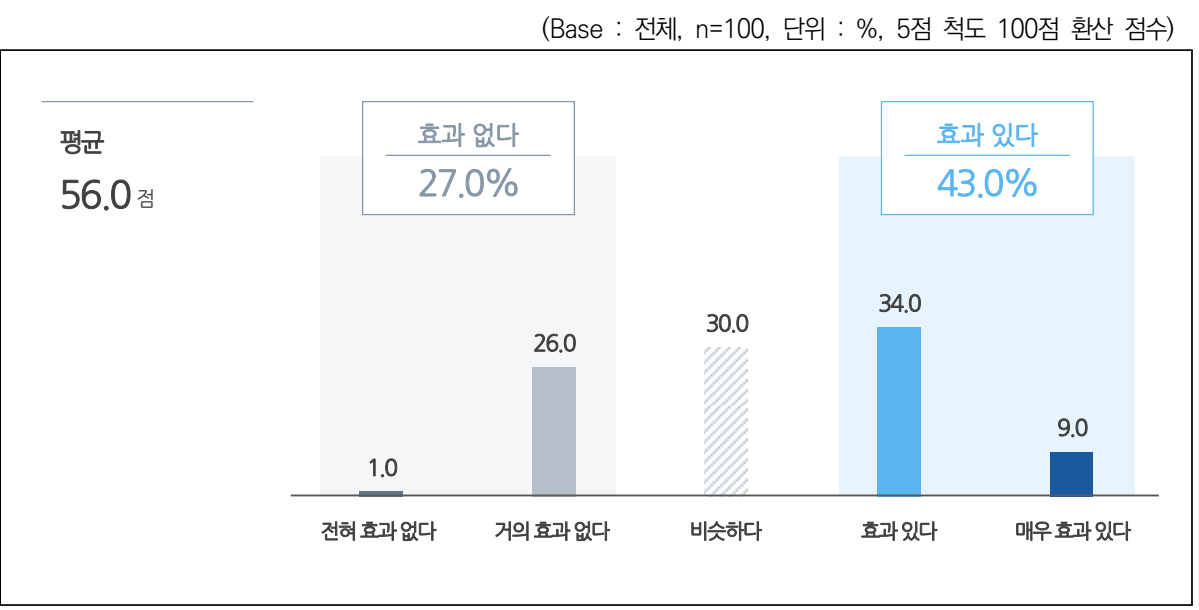

1) 비대면 방식의 국제문화교류 사업이 대면보다 덜 효과적인 이유

코로나19 이후 비대면 방식의 국제문화교류 사업 효과성에 대해 부정적으로 평가한 응답자를 대상으로, 비대면 방식이 대면보다 덜 효과적인 이유에 대해 추가로 설문하였 다. 우선 교류의 깊이, 질적 한계가 존재한다는 의견이 $34.0 \%$ (16건)로 가장 많이 언급되 었다. 그리고 몰입감/집중도의 약화 등 '현장성 부족' $27.7 \%$ (13건), 대면 방식의 효과성, 직접 경험의 한계 등 '비대면 사업 업무 특성상의 한계' $12.8 \%$ (6건) 등으로 나타났다. 이는 국제문화교류의 특성상 공감, 소통, 참여와 같이 문화예술의 경험적 맥락이 중요한 
것으로 비춰진다. 이에 비대면 방식의 사업 수행 문제점을 파악한 후 반영하여 향후 더 나은 비대면 콘텐츠, 사업 등으로 개선할 필요가 있다.

2) 비대면 방식의 국제문화교류 사업이 대면보다 더 효과적인 이유

코로나19 이후 비대면 방식의 국제문화교류 사업 효과성에 대해 긍정적으로 평가한 응답자 중 비대면 방식이 대면보다 더 효과적인 이유에 대해 분류해보았다. 우선 낮은 시공간 제약, 저비용, 다양한 소통 방법 등 ‘접근용이성'이 $42.6 \%$ (29건)로 가장 많이 언 급되었다. 그리고 온라인 시스템 활용, 선택과 집중의 용이성 등 '온라인 플랫폼 활용 극대화' $16.2 \%$ (11건), 한류문화/K-POP 확산에 유용, 다양한 종류의 문화체험 등 '다양 한 사업 추진의 가능성', 정보 교환, 실시간 소통 등 '신속한 의사소통' 각각 $11.8 \%$ (8건) 등으로 나타났다. 이는 국제문화교류 사업을 참여하거나 공감하는 데 있어 생동감, 현장 감보다는 온라인, 모바일 플랫폼을 통해 누구나 어디서든 참여할 수 있는 개방성이 매력 적으로 평가된 것으로 보인다.

\section{라. 코로나19로 인한 국제문화교류 사업의 변동이 큰 국가}

코로나 19 로 인해 국가 간 이동이 제한되면서 사업이 중단되는 경우도 발생하며, 온라 인 콘텐츠, 가상현실 플랫폼 등을 활용한 비대면 프로그램 증가 등 많은 변화가 있었다. 이에 코로나19로 인해 경제발전 수준에 따른 국가 유형별 국제문화교류 사업의 변동이 큰 국가에 대해 설문한 결과, 개발도상국 또는 후진국이라는 응답이 각각 $28.0 \%$ 로 높은 비중을 보였다. 그 외 선진국 9.0\%, 중진국이 5.0\%로 나타났다. 이는 개발도상국 또는 후진국의 경우, 선진국에 비해 새로운 비대면 방식의 콘텐츠 등을 발굴하기 위해 필요한 고급 인력, 기술력, 자금력이 부족한 데서 기인한 것으로 추정된다. 다만 큰 차이가 없다 는 응답 또한 $30.0 \%$ 로 나타난 점을 미루어 볼 때, 인적교류와 국가 간 이동이 중심이 되는 국제문화교류의 특성상 국가 형태와 무관하게 대부분의 국가가 영향을 크게 받았 을 것이라는 인식 또한 적지 않은 것으로 보인다. 
[그림 4-4] 코로나19로 인한 국제문화교류 사업의 변동이 큰 국가

(Base: 전체, $n=100$, 단위: \%)

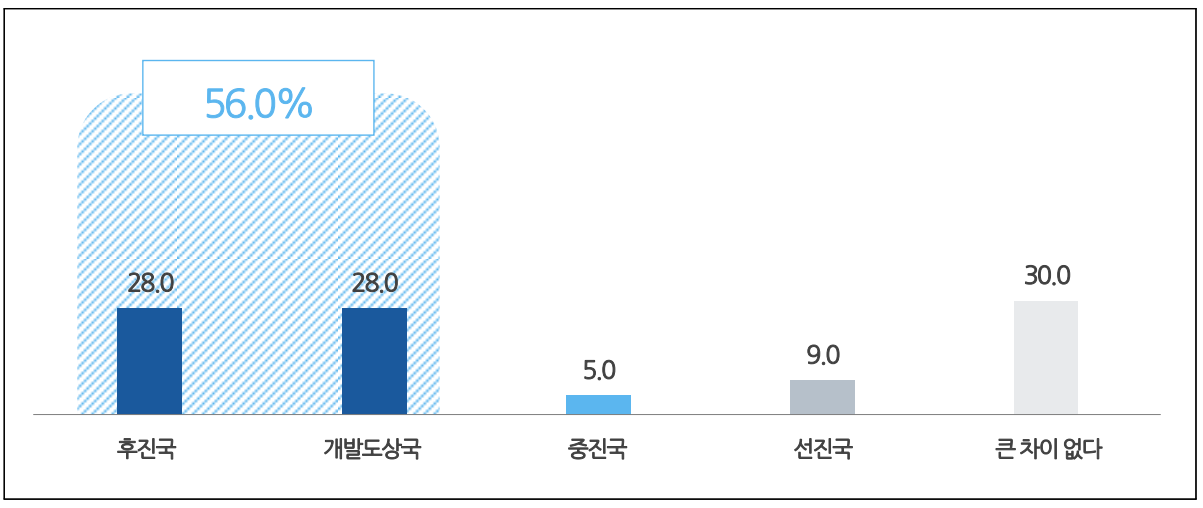

\section{마. 코로나19 기간 내 온라인 교류사업 참여 여부}

코로나19 기간 내 국제문화교류 사업 진행에 있어서 온라인 방식으로 사업이 대체되 는 경우가 많았다. 이에 코로나19 팬데믹 이후 온라인 교류 사업 참여 여부에 대하여 설문하였다. 온라인 교류사업 참여 여부를 살펴보면, 참여했다는 응답이 $72.0 \%$ 로 나타 났다. 이는 코로나19 이후 비대면 문화 콘텐츠, 교육 등이 증가하면서 많은 문화예술계 에서도 접촉, 현장 중심이었던 문화교류 사업의 한계를 극복하고자 노력한 것으로 보인 다. 문화 분야에 종사하는 경우, 온라인 교류사업에 참여했다는 응답이 $82.1 \%$ 로 나타났 다. 반면 예술 분야에 종사하는 경우 58.6\%로 비교적 낮은 참여율을 보였다. 이는 음악, 영화와 같이 대중적 색채가 강한 문화 산업에 비해, 전시·공연 등의 예술 산업의 경우 여전히 현장 중심, 참여자들과의 소통을 더 중요하게 생각하기 때문인 것으로 보인다. 국제관계 종사 분야의 경우에도, 온라인 교류사업에 참여했다는 응답이 $33.3 \%$ 로 낮게 나타났다. 이는 여전히 국가 간 직접적인 이동을 통해 공식적인 협상 및 교류를 중요하 게 생각하는 국제관계 분야의 특징이 반영된 것으로 보인다. 
[그림 4-5] 코로나19 기간 내 온라인 교류사업 참여 여부

(Base: 전체, $n=100$, 단위: \%)

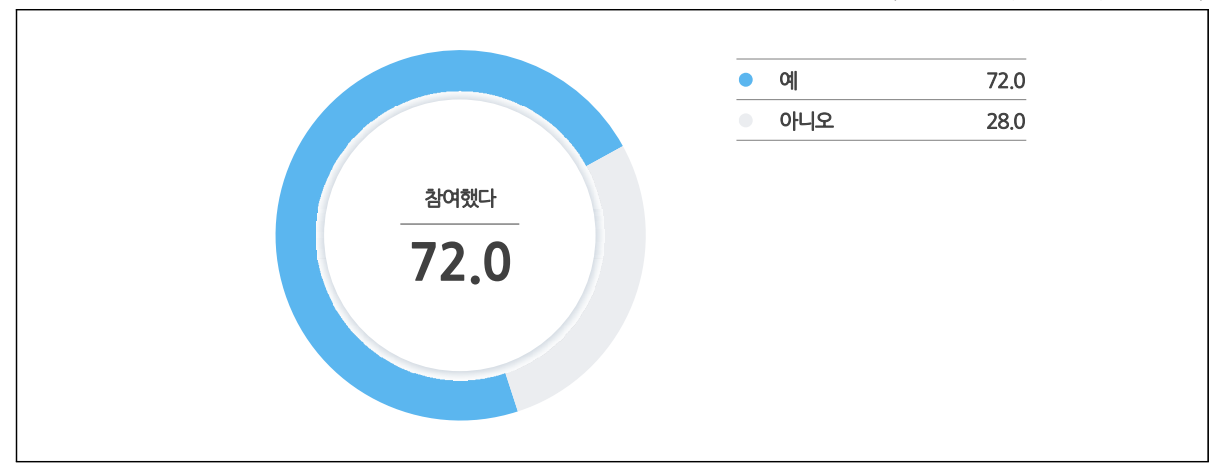

\section{1) 교류사업 참여시 온라인/비대면 콘텐츠 활용방식}

온라인/ 비대면 콘텐츠의 활용에도 여러 방식을 사용할 수 있다. 코로나19 기간 내 온라인으로 교류사업을 참여해본 적이 있는 국제 문화예술 전문가들을 대상으로 온라인 /비대면 콘텐츠 활용방식에 대해 설문하였다. 응답자의 대다수는 ‘라이브 스트리밍' , ‘녹 화 영상의 송출 방법’을 주로 활용하는 것으로 나타났다. ‘라이브 스트리밍' $88.9 \%$, ‘녹 화 영상의 송출' $80.6 \%$ 인 것에 비해, '온라인 뷰잉룸' $23.6 \%$, '가상현실(VR)/증강현실 (AR) 등 실감콘텐츠' $15.3 \%$ 에 불과했다. 국제관계 분야에 종사하는 경우, 그 특성상 가 상현실을 활용한 교류사업을 진행하기 어렵기 때문에 활용 경험이 없는 것으로 나타났다.

\section{[그림 4-6] 교류사업 참여시 온라인/비대면 콘텐츠 활용방식}

(Base: 온라인 교류사업 참여자, $\mathrm{n}=72$, 단위: \%, 복수응답)

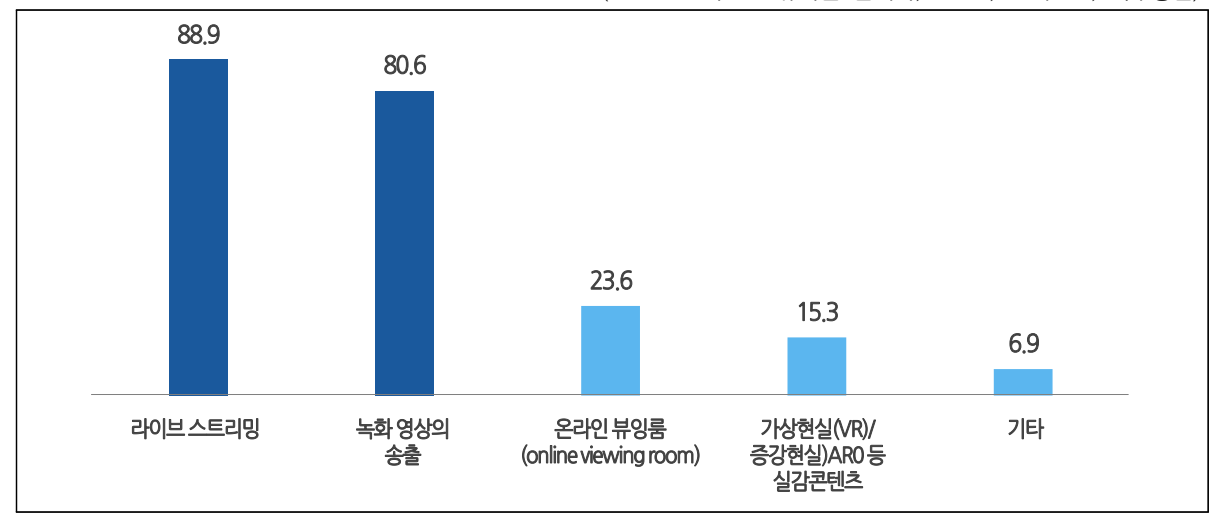




\section{2) 교류사업 참여시 온라인/비대면 프로그램이 유통·송출된 플랫폼}

온라인으로 진행된 교류사업이 어떤 플랫폼을 통하여 주로 유통되었는지 확인할 필요 가 있다. 코로나19 기간 내 온라인으로 교류사업을 참여해본 적이 있는 응답자들을 대상 으로 온라인/비대면 프로그램이 유통·송출된 플랫폼 유형을 살펴보았다. 그 결과, 응답 자의 83.0\%가 줌(Zoom), 구글 미트(Google Meet)와 같은 '온라인 화상회의 앱'을 사 용하는 것으로 나타났다. 그리고 '유명 인터넷 플랫폼' 또한 59.7\%로 비교적 높은 활용 수준을 보였다. 이어서 '기관 홈페이지' $31.9 \%$, '유명 SNS' $26.4 \%$ 등으로 나타났다. 예 술 분야에 종사하는 경우, 응답자의 $29.4 \%$ 가 '온라인 예술 콘텐츠 플랫폼(예.artnet, artsy, eazel. cava, life 등'’을 활용했으며, 타 분야 대비 활용 정도가 높았다. 반면 국 제관계 분야에 종사는 경우, 그 특성상 '온라인 예술 콘텐츠 플랫폼'을 활용한 경우가 없는 것으로 나타났다.

[그림 4-7] 교류사업 참여시 온라인/비대면 프로그램이 유통·송출된 플랫폼

(Base: 온라인 교류사업 참여자, $\mathrm{n}=72$, 단위: $\%$, 복수응답)

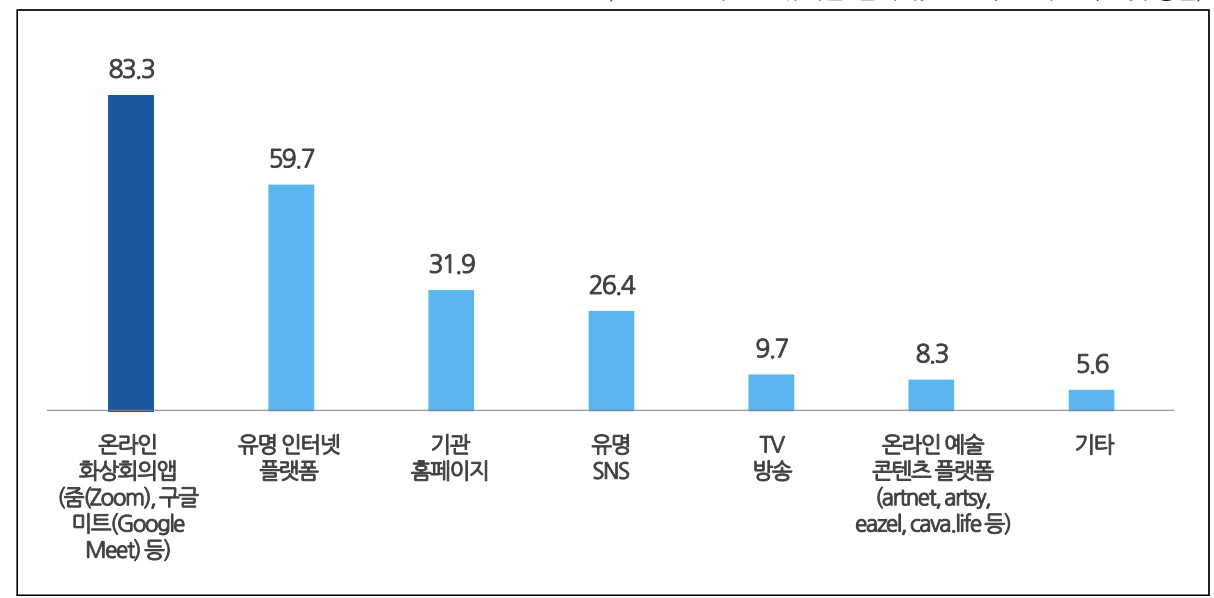

3) 온라인/비대면 프로그램에 참여하지 않은 이유

코로나 19 이후 많은 행사와 프로그램들이 온라인/비대면 방식으로 진행되었다. 이에 오프라인/대면 방식과 다른 상황에 불편함을 느끼거나 거부감을 가지는 경우가 생각보 다 많이 나타나기도 하였다. 따라서 온라인/ 비대면 프로그램에 참여하지 않은 이유에 대해서도 파악할 필요가 있다. 코로나19 기간 내 온라인으로 교류사업에 참여해본 적이 
없는 응답자들을 대상으로 참여하지 않은 이유에 대해 설문한 결과. 전체 응답자 중 67.9\%가 ‘온라인/비대면 콘텐츠 활용이 적절하지 않아서'인 것으로 나타났다. 이어서 '온라인/비대면 콘텐츠 제작/중계/송출/유통을 위한 시설이나 장비가 없다’라는 응답이 $21.4 \%$ 로 나타났다. 다만 예술 분야의 경우, '온라인/비대면/콘텐츠 제작/중계/송출/유 통을 위한 기술을 몰라서'라는 응답이 $33.3 \%$ 로 타 분야 대비 높게 나타났다. 향후 문화 예술인 맞춤형 디지털 매체/기술 개발 및 활용을 통해 문화예술계의 경쟁력을 확보하여, 비대면 기반의 문화예술생태계를 조성할 필요가 있는 것으로 보인다.

[그림 4-8] 온라인/비대면 프로그램에 참여하지 않은 이유

(Base : 온라인 교류사업 비(非)참여자, $\mathrm{n}=28$, 단위 : \%, 복수응답)

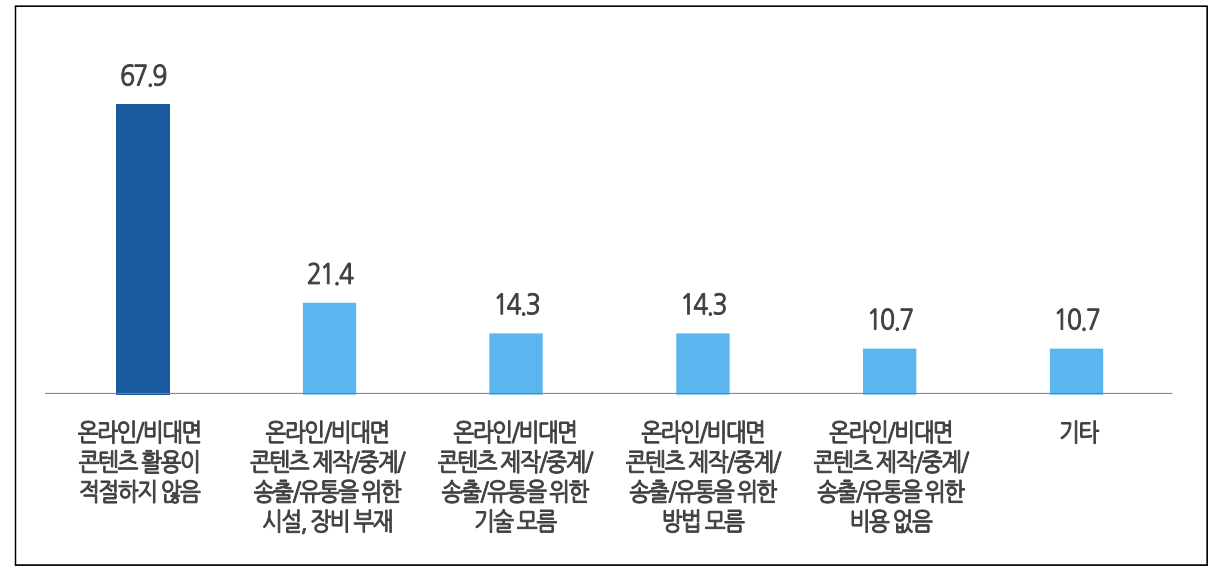

\section{2. 국제문화교류 정책/사업만족도}

\section{가. 코로나19로 발생한 변화가 국제문화교류 사업에 미친 영향}

1) 사회적 변화

사회적 변화가 국제문화교류 사업에 미친 영향에 대한 물음에 응답자의 $93.0 \%$ 가 코 로나19 팬데믹 이후 재택근무, 사회적 거리두기, 비대면 문화의 확산 등의 사회적 변화 가 국제문화교류 사업 진행에 영향을 미쳤다고 답변하였다. 40대 이상 또는 문화 분야, 국제관계 분야에 종사하는 경우, 영향을 미치지 않았다는 응답이 나타나지 않았다. 


\section{2) 기술적 변화}

기술적 변화가 국제문화교류 사업에 미친 영향에 대한 물음에 응답자의 $95.0 \%$ 가 코 로나19 팬데믹 이후 디지털 활용을 중심으로 한 기술적 변화가 국제문화교류 사업 진행 에 영향을 미쳤다고 답변하였다. 전반적으로 부정 응답은 나타나지 않았고, 60 대 이상의 경우 응답자 전체가 영향을 미쳤다고 답변하였다.

\section{3) 국제정치 변화}

국제정치 변화가 국제문화교류 사업에 미친 영향에 대한 물음에 응답자의 88.0\%가 코로나19 팬데믹 이후 교류 중단, 연기 등 국제정치 변화가 국제문화교류 사업 진행에 영향을 미쳤다고 답변하였다. 40대 이상 또는 예술 분야, 국제관계 분야에 종사하는 경 우, 영향을 미치지 않았다는 응답이 나타나지 않았다.

\section{4) 경제적 변화}

경제적 변화가 국제문화교류 사업에 미친 영향에 대한 물음에 응답자의 $84.0 \%$ 가 코 로나19 팬데믹 이후 비대면 경제 활성화, 경기침체, 경제활동 양상의 변화 등 경제적 변화가 국제문화교류 사업 진행에 영향을 미쳤다고 답변하였다. 40대 이상 또는 예술 분야, 국제관계 분야에 종사하는 경우, 영향을 미치지 않았다는 응답이 나타나지 않았다.

\section{5) 문화생활 변화}

문화생활 변화가 국제문화교류 사업에 미친 영향에 대한 물음에 응답자의 $94.0 \%$ 가 코로나19 팬데믹 이후 대면 공연 전시 등의 어려움, 온라인 문화콘텐츠 활용 등 문화생 활 변화가 국제문화교류 사업 진행에 영향을 미쳤다고 답변하였다. 40대 이상에서 영향 을 미치지 않았다는 응답이 나타나지 않았고, 예술 분야 또는 국제관계 분야에 종사하는 경우 응답자 전체가 영향을 미쳤다고 답변하였다. 


\section{나. 국제문화교류 사업에 대한 정책·지원에 대한 만족도}

국제문화교류 사업에 대한 정부의 정책과 지원에 대한 만족 정도를 묻는 설문에 응답 자들의 코로나19 팬데믹을 전후 인식의 차이를 확인하였다. 코로나 19 이전에는 만족한 다는 응답이 $32.0 \%$ 로 불만족한다는 응답 $7.0 \%$ 에 비해 높았던 반면, 코로나 19 이후로는 불만족한다는 응답이 $30.0 \%$ 로 만족한다는 응답 $15.0 \%$ 에 비해 높았다. 평균 점수 또한 코로나19 이전 56.8점, 코로나19 이후 45.3점으로 나타났다. 전체적으로 '보통이다'라 는 응답이 코로나 이전 $61 \%$, 코로나 이후 55\%로 크게 국제문화교류에 대한 정부정책에 큰 선호인식이 없는 것으로 나타났다. 특히 코로나19 이후로는 전반적으로 국제문화교 류 사업에 대한 정책과 지원에 대해 '매우 만족'한다는 응답이 나타나지 않았고, 국제관 계 분야에서 종사하는 경우 만족한다는 응답이 나타나지 않았다. 팬데믹 이후 국제문화 교류 사업 피해를 보전하기 위한 여러 지원책들이 나오고 있지만, 응답자들은 아직 충분 하지 못하다고 인식하고 있는 것으로 보인다.

[그림 4-9] 국제문화교류 사업에 대한 정책·지원에 대한 만족도

(Base : 전체, $n=100$, 단위 : \%, 5점 척도 100점 환산 점수)

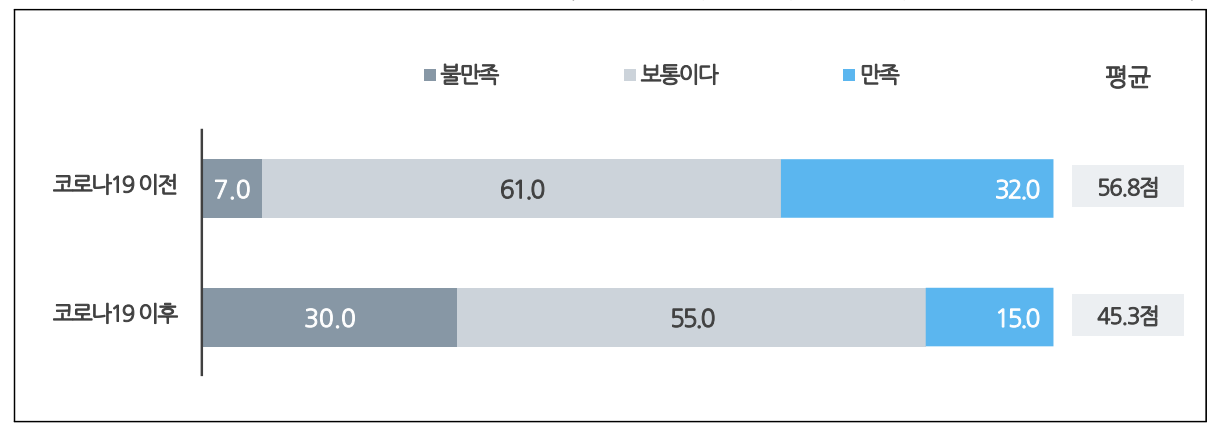

\section{다. 코로나19로 인한 정부의 국제문화교류사업 지원에 대한 필요성 인식}

코로나19로 인하여 국제문화교류 사업을 이전처럼 원활하게 진행하기 힘든 상황에서, 사업계획 변경에 따른 행정 절차의 간소화, 계획 변경에 따른 유연한 예산 집행 지원, 비대면 사업 진행을 위한 편의 제공, 디지털 기술 활용을 통한 사업 진행을 위한 예산 확대 등 다양한 형태의 정부 지원이 진행되었다. 
응답자들은 현재 시점까지 정부로부터 받은 지원들이 향후에도 더욱 필요하다고 인식 하고 있었다, 특히 유연한 예산 집행 지원과 행정 절차의 간소화에 대한 향후 필요성을 크게 느끼고 있었으며, 이에 대한 우선적인 지원을 고려해야 할 것으로 보인다.

지원 유형별로 살펴보면, 유연한 예산 집행 지원은 현재 정부로부터 받은 지원에 대한 필요성 $73.0 \%$, 향후 필요성 $90.0 \%$ 로 $17.0 \%$ p 더 높았다. 행정 절차의 간소화는 현재 정부로부터 받은 지원에 대한 필요성 $72.0 \%$, 향후 필요성 $86.0 \%$ 로 $14.0 \%$ p 더 높았다. 비대면 사업 진행을 위한 편의 제공은 현재 정부로부터 받은 지원에 대한 필요성 $67.0 \%$, 향후 필요성 $85.0 \%$ 로 $18.0 \%$ p 더 높았다. 디지털 기술 활용을 통한 사업 진행을 위한 예산 확대는 현재 정부로부터 받은 지원에 대한 필요성 $69.0 \%$, 향후 필요성 $84.0 \%$ 로 $15.0 \% \mathrm{p}$ 더 높았다.

[그림 4-10] 정부로부터 받은 지원 및 향후 필요한 지원에 대한 필요성 인식

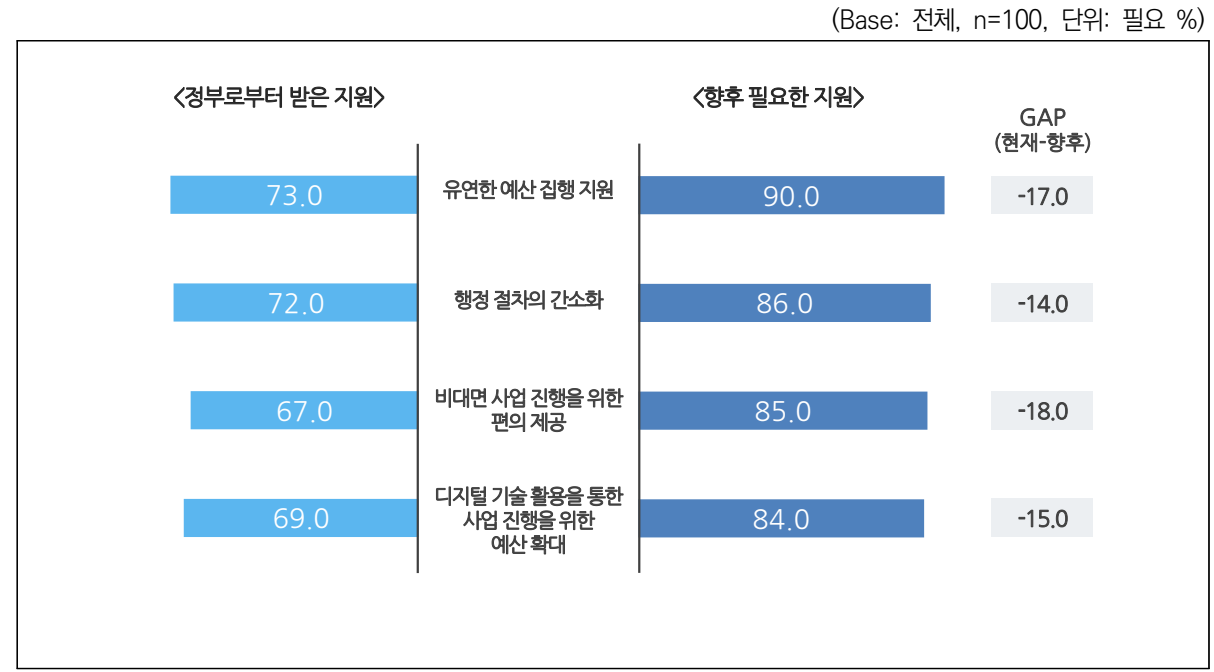

\section{라. 위기/재난상황시 국제문화교류사업 추진을 위한 정책의 필요성}

코로나19 팬데믹 이전과 비교하여, 향후 코로나19와 같은 위기/재난상황이 발생했을 때 국제문화교류 사업 추진을 위해 필요한 정책에 대한 준비가 필요해보인다. 위기/재난 상황에서 국제문화교류 사업 추진을 위해 필요한 정책에 대해 설문한 결과, 세부 정책별 로 차이를 보였다. 필요하다는 응답 비중을 기준으로, '국제문화교류 사업 기관 네트워 
킹 및 협업 강화' $91.0 \%$, '기관별 네트워크 구축 및 연계사업 개발' $88.0 \%$, '사업계획 플랜B 설계 지원' $88.0 \%$ 등의 순으로 나타났다. 반면, '해외 현지 활동 문화원(사무소) 확대’ $62.0 \%$, ‘통합상담센터 운영 및 정보 제공' $69.0 \%$, ‘국제문화교류 전담기관 사업 및 예산 확대' $76.0 \%$ 등으로 나타나, 상대적으로 그 필요성을 낮게 인식하고 있는 것으 로 보인다.

[그림 4-11] 위기/재난상황시 국제문화교류사업 추진을 위한 정책의 필요성

\begin{tabular}{|c|c|c|}
\hline & \multicolumn{2}{|c|}{ (Base: 전체, $n=100$, 단위: $\%, 5$ 점 척도 100 점 환산 점수) } \\
\hline & - 필요하다 $(\%)$ & 평균 \\
\hline 국제문화교류사업 기관네트워킹 및 협업 강화 & 91.0 & 83.0점 \\
\hline 기관별 네트워크구축 및 연계사업 개발 & 88.0 & 80.8점 \\
\hline 사업계획플랜B 설계지원 & 88.0 & 79.3점 \\
\hline 디지털기술활용활성화 방안개발 & 87.0 & 80.5점 \\
\hline 온라인/비대면 콘텐츠제작·유통 활성화지원 & 87.0 & 84.0점 \\
\hline 예산확대및 예산 계획 수립과집행의 자율성증대 & 86.0 & 78.8점 \\
\hline 정부부처간협력강화 & 86.0 & 80.8점 \\
\hline 국제문화교류사업을 위한사전조사연구지원 & 86.0 & 80.3점 \\
\hline $\begin{array}{l}\text { 위기(재난) 발생 시사업계획에 대한 } \\
\text { 가이드라인제작 및 배포 }\end{array}$ & 84.0 & 79.8점 \\
\hline 전문인력양성확대 & 82.0 & 80.3점 \\
\hline 역량강화를 위한 교육훈련 지원 & 80.0 & 78.3점 \\
\hline 국제문화교류 전담기관사업 및 예산확대 & 76.0 & 77.3점 \\
\hline 통합상담센터 운영 및 정보제공 & 69.0 & 70.5점 \\
\hline 해외 현지 활동문화원(사무소)확대 & 62.0 & 71.8점 \\
\hline
\end{tabular}




\section{3. 코로나 이후 국제문화교류 발전 방향}

\section{가. 코로나19 이후 국제문화교류 활성화를 위한 정책의 필요성}

코로나 19로 인한 비정상적 상황을 벗어나서 새롭게 국제문화교류 정책을 정상적으 로 시행할 수 있다면, 무엇을 준비해야할 지에 대한 깊은 고민이 필요하다. 코로나19 팬데믹에서 벗어난 이후, 국제문화교류 활성화를 위해 필요한 정책에 대해 설문하였다. 그 결과, '국제문화교류 국내체계 정비 93.0\%,' '온라인/비대면 콘텐츠 제작.유통 활성 화 지원' $92.0 \%$, '국제문화교류 정책의 구체화, 체계화' $91.0 \%$ 등의 순으로 나타났다. 반면, '해외 실감콘텐츠(K-Pop, 영화, 게임, 문화유산) 체험관 구축'은 64.0\%로, 상대적 으로 그 필요성을 낮게 인식하고 있는 것으로 보인다.

[그림 4-12] 코로나19 이후 국제문화교류 활성화를 위한 정책의 필요성

\begin{tabular}{|c|c|c|}
\hline & \multicolumn{2}{|c|}{ (Base: 전체, $n=100$, 단위: $\%, 5$ 점 척도 100 점 환산 점수) } \\
\hline & - 필요하다 $(\%)$ & 평균 \\
\hline 국제문화교류 국내체계 정비 & 93.0 & 84.3점 \\
\hline 온라인/비대면 콘텐츠제작유통 활성화 지원 & 92.0 & 83.0점 \\
\hline 국제문화교류 정책의 구체화, 체계화 & 91.0 & 83.3점 \\
\hline $\begin{array}{r}\text { 국제문화교류 위한문화콘텐츠샛사ㄴㅏㅏ, 소비, 유통등 } \\
\text { 세분야별 사법 지원 }\end{array}$ & 90.0 & 82.5점 \\
\hline 비대면 온라인상시 문화교류 사업상시기획 및 사업추진 & 85.0 & 80.0점 \\
\hline 한국국제문화교류 온라인 플랫폼 구축 및 활용활성화 & 83.0 & 79.3점 \\
\hline 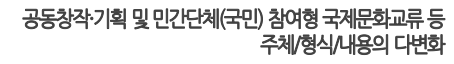 & 81.0 & 78.8점 \\
\hline 실혐적인 창작활동의 국제교류:협업 활성화지원 & 81.0 & 77.3점 \\
\hline $\begin{array}{l}\text { 가치지향적 국제문화교귤 정책을위한항 } \\
\text { 공가치 비넌의입 }\end{array}$ & 78.0 & 74.3점 \\
\hline 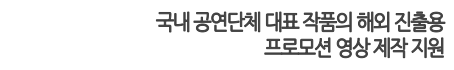 & 78.0 & 75.0점 \\
\hline 한국여행, 관광, 문화 콘텐츠온라인 홍보 & 77.0 & 76.3점 \\
\hline 국제문화교류 사업 성과관리체계 구축 & 76.0 & 77.5점 \\
\hline 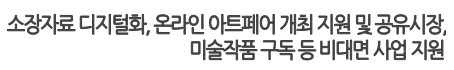 & 76.0 & 75.5점 \\
\hline 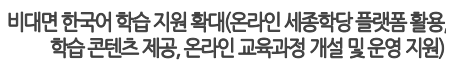 & 76.0 & 77.0점 \\
\hline 해외실감콘텐츠(K-Pop, 영화, 게임, 문화유산) 체험관구축 & 64.0 & 68.8점 \\
\hline
\end{tabular}




\section{나. 코로나19 이후 민간분야 국제문화교류 활동 활성화를 위해 필요한 지원}

국제문화교류는 정부가 공공영역의 파트너들과만이 진행할 수 있는 사업이 아니다. 민간 영역에서도 자유롭게 국제문화교류 프로그램을 구성하고 운영할 수 있다. 코로나 19 로 인하여 민간영역의 국제문화교류 활동의 축소가 더욱 심각하다. 따라서, 코로나19 이후 민간영역의 국제문화교류 활성화를 위해 필요한 지원을 고민하여야 한다. 코로나 19 팬데믹에서 벗어난 이후, 민간분야의 국제문화교류 활동 활성화를 위해 필요한 정부 의 지원 형태에 대해 설문한 결과, 필요하다는 응답 비중을 기준으로 '온라인 디지털 국 제문화교류 플랫폼을 통한 활동 지원’ $88.0 \%$, ‘국제문화교류 정보공유 및 활용 지원(네 트워크 구축)' $88.0 \%$ 등으로 나타났다. 반면, '영사서비스 및 해외사무소 업무 지원' $69.0 \%$, '사업공모 등을 통한 사업 지원' $78.0 \%$ 등으로 나타나, 상대적으로 그 필요성으 로 낮게 인식하고 있는 것으로 보인다.

[그림 4-13] 코로나19 이후 민간분야 국제문화교류 활동 활성화를 위해 필요한 지원 (Base: 전체, $n=100$, 단위 : \%, 5점 척도 100점 환산 점수)

\begin{tabular}{|c|c|c|}
\hline & - 필요하다 (\%) & 평균 \\
\hline $\begin{array}{l}\text { 온라인디지텅굴제문화교률 } \\
\text { 플랫폼올항활동지원 }\end{array}$ & 88.0 & 81.8점 \\
\hline $\begin{array}{l}\text { 국제문화교류 정보공유ㅁㅣㅣ } \\
\text { 활용지원(네트워크구국) }\end{array}$ & 88.0 & 80.8점 \\
\hline $\begin{array}{l}\text { 콘텐츠디지털 전환등 } \\
\text { 인력교육및상비항지원 }\end{array}$ & 86.0 & 79.5점 \\
\hline 사업비용지원 & 82.0 & 78.5점 \\
\hline $\begin{array}{l}\text { 핳국ㄱㅜㅜ제뭄화교류ㄹㅗㅗ라잉 } \\
\text { 플새ㅅㅗㅗㅁㄱㅜㅜㅜㄱ및 활용활성화 }\end{array}$ & 80.0 & 79.5점 \\
\hline 사업공모등을통한사업지원 & 78.0 & 75.3점 \\
\hline $\begin{array}{l}\text { 영사서비스및해외사무소옵 웁지원 }\end{array}$ & 69.0 & 72.0점 \\
\hline
\end{tabular}

\section{다. 국제문화교류 관련 업무 수행·계획시 온라인/비대면 콘텐츠 활용 의향}

향후 국제문화교류와 관련된 업무를 수행하거나 사업을 계획할 때, 응답자의 94\%가 온라인/비대면 콘텐츠를 활용할 의향이 있는 것으로 조사되었다. 기존에는 온라인/비대 면 콘텐츠를 보완재 혹은 대체재의 개념으로 바라보았으나, 코로나19 팬데믹 이후에는 필수적인 요소로 그 위상이 바뀌었다고 볼 수 있다. 


\section{라. 코로나19 이후 온라인/비대면 콘텐츠 부상에 대한 전망 및 평가}

코로나19 팬데믹 이후 온라인/비대면 콘텐츠가 급격히 부상하게 되면서, 응답자들은 물리적·시간적·경제적·심리적 차원의 접근성 확대, 국제문화교류 향유자가 오프라인에 서 온라인으로의 신규 유입에 따른 새로운 사업 확대, 그리고 문화, 예술, 관광, 체육 등 다양한 분야에서의 콘텐츠 활용 등에 대해 대체로 긍정적으로 전망하는 것으로 나타 났다. 다만 다양한 분야에서의 콘텐츠 활용에 대한 긍정 응답 비중이 $59.0 \%$ 로, 접근성 확대 $94.0 \%$, 새로운 사업 확대 $87.0 \%$ 에 비교했을 때 큰 차이를 보였다. 향후 온라인/비 대면 콘텐츠가 갖게 될 영향력을 높게 평가하면서도, 분야별로 폭넓게 활용되어 그 영향 이 고르게 확산될 것이라는 인식과는 격차가 존재하는 것으로 보인다.

[그림 4-14] 코로나19 이후 온라인/비대면 콘텐츠 부상에 대한 전망 및 평가

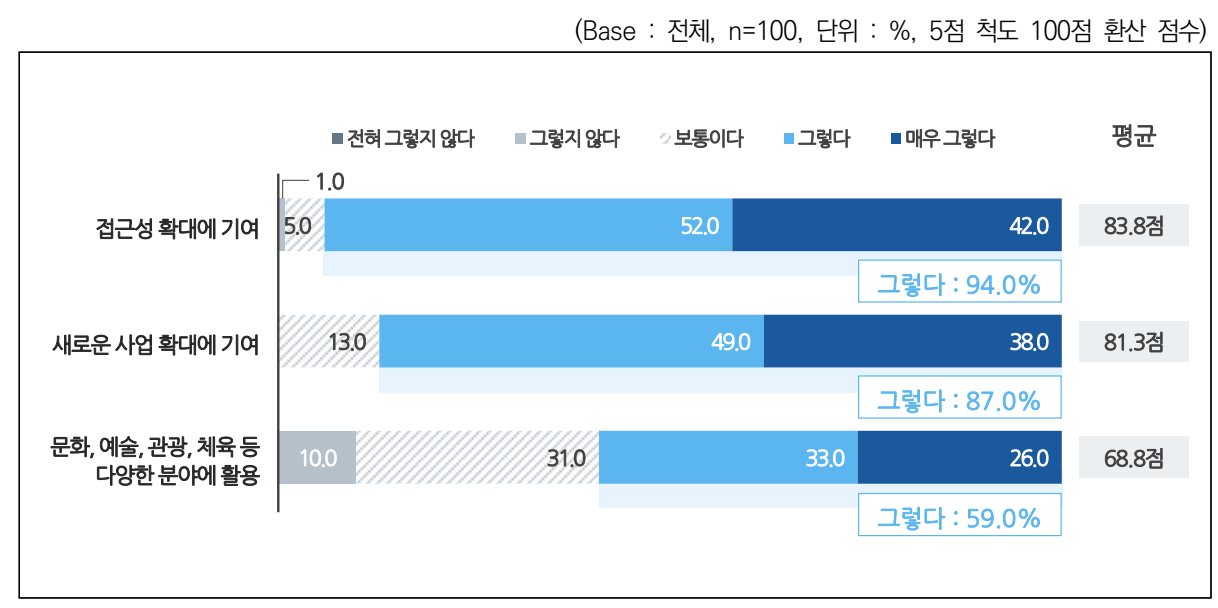

\section{마. 온라인/비대면 콘텐츠 활성화를 위해 필요한 정책적 지원}

코로나 19 팬데믹을 벗어난 이후, 국제문화교류 방식에 있어서 다양화는 지속될 것으 로 보인다. 온라인/비대면 방식이 효율적일 경우 이미 보편화된 방식인 온라인/비대면 방식을 적극 활용할 가능성이 크다. 따라서, 이를 활용한 콘텐츠의 제작 및 운용 활성화 를 위한 정책 지원방안도 고려할 필요가 있다. 관련 설문 결과, 응답자의 $70.0 \%$ 가 온라 인/비대면 콘텐츠를 유통시킬 수 있는 플랫폼을 구축하고 이를 활성화하는 데에 정책적 으로 지원이 필요하다고 보았으며, 이어서 온라인/비대면 콘텐츠 제작에 필요한 비용 지 
원이 필요하다는 응답이 $67.0 \%$, 콘텐츠를 제작할 수 있는 공간 및 시설, 장비에 대한 지원이 필요하다는 응답이 $60.0 \%$ 등의 순으로 나타났다.

문화 분야에 종사하는 경우, 온라인/비대면 콘텐츠를 유통시킬 수 있는 플랫폼을 구축 하고 이를 활성화하는 데에 정책적으로 지원이 필요하다는 응답이 $67.9 \%$ 로 가장 높게 나타났다. 예술 분야에 종사하는 경우, 온라인/비대면 콘텐츠를 유통시킬 수 있는 플랫 폼을 구축하고 이를 활성화하는 데에 정책적으로 지원이 필요하다는 응답이 $79.3 \%$ 로 타 분야 대비 높았으며, 온라인/비대면 콘텐츠 제작에 필요한 비용 지원이 필요하다는 응답이 $82.8 \%$ 로 가장 높았다. 국제관계 분야에 종사하는 경우, 온라인/비대면 콘텐츠 제작에 필요한 비용 지원이 필요하다는 응답이 $88.9 \%$ 로 가장 높았다.

[그림 4-15] 온라인/비대면 콘텐츠 활성화를 위해 필요한 정책적 지원

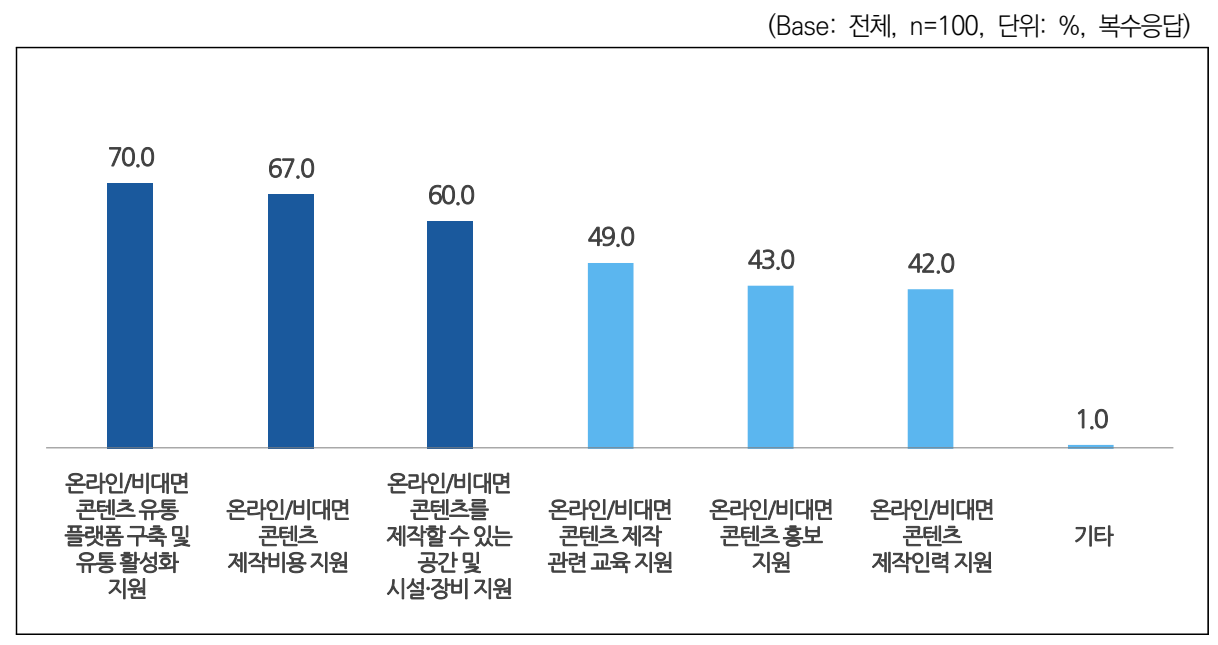

\section{바. '문화로' 활용 경험 여부}

문화체육관광부의 국제문화교류 전담기관인 한국국제문화교류진흥원은 국제문화교 류 종합정보시스템 '문화로'를 운영하고 있다. 이 시스템의 활성화를 위해 필요한 현황 을 파악할 필요가 있다. 국제문화교류 종합정보시스템 '문화로'를 활용해본 경험이 있다 는 응답자는 $22.0 \%$ 에 불과하며, 60 대 이상의 경우 활용 경험이 없는 것으로 조사되었 다. 유관 분야에 종사하고 있다는 응답자의 전반적인 특성을 고려한다면, '문화로' 시스 
템이 구축된 지 2년 남짓인 점을 감안하더라도 낮은 수치라고 볼 수 있다. '문화로' 홍보 및 활용 방안 확대 등에 대한 고민이 필요한 것으로 보인다.

\section{1) '문화로’를 통한 정보의 도움 정도}

'문화로'를 활용해본 경험이 있는 응답자들의 경우, 코로나19 전후 여부와 상관없이 '문화로'를 통해 얻게 된 정보가 실제로 도움이 되었다는 응답이 그렇지 않다는 응답에 비해 낮은 것으로 나타났다. 다만 코로나 19 이전에는 도움이 되었다는 응답이 $13.6 \%$, 도움이 안 되었다는 응답이 $45.5 \%$ 로 나타나 그 차이가 컸던 반면에, 코로나 19 이후에는 도움이 되었다는 응답이 $36.4 \%$, 도움이 안 되었다는 응답이 $40.9 \%$ 로 나타나, 상대적으 로 개선된 양상을 보였다. 이는 온라인상에서 얻게 되는 정보에 대한 의존도가 코로나19 이전 시기에 비해 커지면서 나타난 현상으로 보인다.

\section{2) 코로나19 이후 ‘문화로’ 개선 방향}

‘문화로'를 활용해본 경험이 있는 응답자들의 $50.0 \%$ 가, 코로나 19 이후 ‘문화로'가 한 국 국제문화교류 종합플랫폼으로 기능을 강화해야 한다는 의견을 향후 개선 방향으로 언급하였다. 그 외에도 다양한 기관 및 사업에 대한 정보 보완이 필요하다는 의견이 많 았고, 수요자의 관점에서 나라별·분야별 메뉴를 추가로 구성하는 동시에 '문화로' 웹사 이트에 대한 적극적인 홍보에 나설 필요가 있다고 보았다.

[그림 4-16] 코로나19 이후 ‘문화로’ 개선 방향

(Base: '문화로' 활용 경험자, $n=22$, 단위: \%)

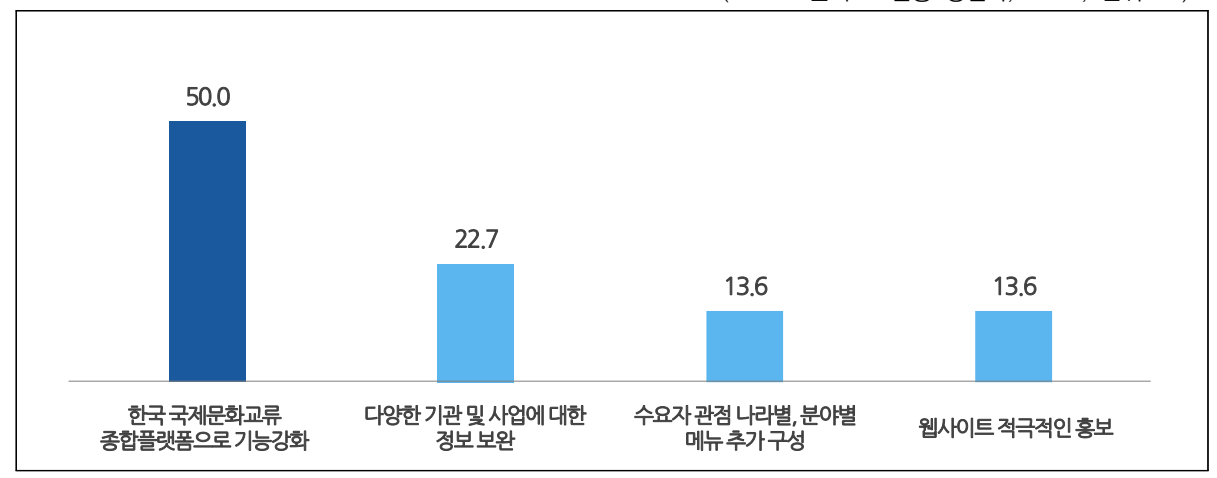




\section{제3절 소 결}

이번 장에서는 국제문화교류 전문가들을 대상으로 하여 설문조사를 실시한 결과를 정 리하였다. 주요 응답 결과는 아래와 같다.

첫 번째, 코로나19 이후 비대면 방식의 국제문화교류 사업 효과성에 대해 부정적으로 평가한 응답자를 대상으로, 비대면 방식이 대면보다 덜 효과적인 이유에 대해 추가로 설문하였다. 우선 교류의 깊이, 질적 한계가 존재한다는 의견이 $34.0 \%$ (16건)로 가장 많 이 언급되었다. 그리고 몰입감/집중도의 약화 등 ‘현장성 부족' $27.7 \%(13$ 건), 대면 방식 의 효과성, 직접 경험의 한계 등 ‘비대면 사업 업무 특성상의 한계’ $12.8 \%$ (6건) 등으로 나타났다.

두 번째, 코로나19 기간 내 온라인으로 교류사업을 참여해본 적이 있는 국제 문화예 술 전문가들을 대상으로 온라인/비대면 콘텐츠 활용방식에 대해 설문하였다. 응답자의 대다수는 '라이브 스트리밍', '녹화 영상의 송출 방법'을 주로 활용하는 것으로 나타났다. '라이브 스트리밍' $88.9 \%$, '녹화 영상의 송출' $80.6 \%$ 인 것에 비해, '온라인 뷰잉룸' $23.6 \%$, '가상현실(VR)/증강현실(AR) 등 실감콘텐츠' $15.3 \%$ 에 불과했다.

세 번째, 코로나19 기간 내 온라인으로 교류사업을 참여해본 적이 있는 응답자들을 대상으로 온라인/비대면 프로그램이 유통·송출된 플랫폼 유형을 살펴보았다. 그 결과, 응답자의 83.0\%가 줌(Zoom), 구글 미트(Google Meet)와 같은 '온라인 화상회의 앱'을 사용하는 것으로 나타났다.

네 번째, 국제문화교류 사업에 대한 정부의 정책과 지원에 대한 만족 정도를 묻는 설문에 응답자들의 코로나19 팬데믹을 전후 인식의 차이를 확인하였다. 코로나19 이전 에는 만족한다는 응답이 $32.0 \%$ 로 불만족한다는 응답 $7.0 \%$ 에 비해 높았던 반면, 코로나 19 이후로는 불만족한다는 응답이 $30.0 \%$ 로 만족한다는 응답 $15.0 \%$ 에 비해 높았다. 평 균 점수 또한 코로나19 이전 56.8점, 코로나19 이후 45.3점으로 나타났다. 전체적으로 '보통이다'라는 응답이 코로나 이전 $61 \%$, 코로나 이후 $55 \%$ 로 크게 국제문화교류에 대 
한 정부정책에 큰 선호인식이 없는 것으로 나타났다.

다섯 번째, 코로나19로 인한 정부의 국제문화교류사업 지원에 대한 필요성 인식에 있 어 응답자들은 현재 시점까지 정부로부터 받은 지원들이 향후에도 더욱 필요하다고 인 식하고 있었다, 특히 유연한 예산 집행 지원과 행정 절차의 간소화에 대한 향후 필요성 을 크게 느끼고 있었으며, 이에 대한 우선적인 지원을 고려해야 할 것으로 보인다.

여섯 번째, 코로나 19 와 같은 위기/재난상황이 발생했을 때 국제문화교류 사업 추진을 위해 필요한 정책에 대해 설문한 결과, '국제문화교류 사업 기관 네트워킹 및 협업 강화' 91.0\%, '기관별 네트워크 구축 및 연계사업 개발' $88.0 \%$, '사업계획 플랜B 설계 지원' $88.0 \%$ 등의 순으로 그 필요성에 대하여 인식하고 있음을 확인하였다.

일곱 번째, 코로나19 팬데믹에서 벗어난 이후, 국제문화교류 활성화를 위해 필요한 정책에 대해 설문한 결과, '국제문화교류 국내체계 정비 93.0\%' '온라인/비대면 콘텐츠 제작·유통 활성화 지원' $92.0 \%$, '국제문화교류 정책의 구체화, 체계화' $91.0 \%$ 등의 순 으로 나타났다.

마지막으로, 코로나19 팬데믹에서 벗어난 이후, 민간분야의 국제문화교류 활동 활성 화를 위해 필요한 정부의 지원 형태에 대해 설문한 결과, 필요하다는 응답 비중을 기준 으로 '온라인 디지털 국제문화교류 플랫폼을 통한 활동 지원' $88.0 \%$, '국제문화교류 정 보공유 및 활용 지원(네트워크 구축)' $88.0 \%$ 등으로 나타났다.

이상의 전문가 설문조사 결과, 코로나 이후 국제문화교류의 중요성이 더욱 증대될것 으로 기대하고 있고, 코로나 상황을 고려한 국제문화교류 사업 추진에 있어서 유연한 예산 집행 지원과 행정 절차의 간소화에 대한 향후 필요성 등의 부분에서 정부의 정책적 지원의 필요성을 인식하고 있음을 알 수 있다. 그리고 코로나와 같은 재난 상황에서 필 요한 정책 방안으로 '국제문화교류 사업 기관 네트워킹 및 협업 강화', '기관별 네트워크 구축 및 연계사업 개발' , '사업계획 플랜B 설계 지원' 등의 순 중요성을 인식하고 있음을 확인하였다. 코로나19 팬데믹에서 벗어난 이후, 국제문화교류 활성화를 위해 필요한 정 책에 대해서는 '국제문화교류 국내체계 정비', '온라인/비대면 콘텐츠 제작·유통 활성화 지원' '국제문화교류 정책의 구체화, 체계화' 순으로 중요하다고 인식하고 있고, 한국 국 제문화교류의 공통의 가치 비전 정립에 대해서는 그 인식 수준이 상대적으로 낮다는 것 을 알 수 있다. 이는 한국의 국제문화교류사업이 각 추진 기관별로 개별적으로 진행되고 있음을 보여주는 것이다. 

코로나19 이후 국제문화교류 활성화방안 연구

제5장

국제문화교류 활성화위한 정책과제 



\section{제1절 정책추진 환경}

\section{1. 국제문화교류 추진 환경}

앞서 살펴본 바와 같이, 현재 국제문화교류를 둘러싼 환경적 요인은 국제문화교류 촉 진에 방해가 되는 요인들이 더 많이 존재하고 있다. 국제정치적으로는 마중경쟁으로 대 변되는 강대국 간 갈등 상황이 한동안 지속될 가능성이 크다. 그리고 주요 선진국들을 중심으로 코로나19 팬데믹 이전부터 부상해오던 자국 중심주의와 다자주의 축소의 움직 임이 지속되면서 일부 국제정치적 질서의 변화를 추동하려고 하는 측면 역시 존재한다. 이 상황에서 전세계 국제문화교류의 전체 규모는 줄어들 가능성이 크다. 특히 개발도상 국들의 경우 코로나 19 팬데믹 극복에 걸리는 시간이 다른 중견국 이상의 주요 국가들에 비해 느려질 것으로 예상된다는 점에서 코로나19 이전의 국제문화교류 수준을 언제쯤 회복할 것인가를 예측하기엔 쉽지 않은 상황이다.

경제적으로도 코로나19 팬데믹은 이미 진행 중인 다양한 경제적 어려움을 가중하고 있다. 코로나19 팬데믹 이전에도 전 세계적인 구조적 침체가 상당 기간 지속되었으나, 코로나 19 로 인한 상품교역과 인적교류의 축소는 이러한 침체를 더욱 악화시키고 있다. 이러한 경제적 어려움 속에서도 새로운 디지털 기술을 활용한 새로운 사업들이 경제성 장을 견인하고 있다. 경제영역 전반에 적용되고 있는 디지털 기술의 접목과 활용은 코로 나19 상황에서 가속화되고 있다. 이러한 디지털 전환이라는 맥락에서 신규 사업들의 성 장은 코로나19로 인한 어려움을 어느 정도 줄이는 효과를 거두게 하고 있다. 코로나19 팬데믹 상황을 통해 새로운 기회와 가치를 창출하는 승자와 그렇지 못한 패자 사이의 간극은 커지고 있다. 이는 기존의 경제적 양극화 현상을 더욱 악화시키고 더 큰 사회적 문제를 야기하고 있다.

사회문화적으로는 다양한 집단 간, 개인 간 갈등이 더욱 첨예화하고 있다. 특히, 경제적 불평등과 함께 사회적 불평등 역시 악화하고 있다. 경제 침체로 인한 청년 취업이 어려워지 
고 청년층의 계층 상승 여지가 줄어든 가운데 세대 간 갈등이 심해지면서 여러 가지 사회문 제가 발생하고 있다. 게다가 저출산·고령화 현상의 지속으로 인한 인구 감소가 예측되면서 다양한 사회문제와 갈등이 증가할 것으로 예상된다. 또한, 1 인 가구 등 새로운 가구형태가 확산은 공동체와 삶의 방식에 영향을 미치고 있다. 코로나19 팬데믹을 극복하기 위한 사회적 거리두기의 일상화와 비대면 교류의 확대는 이러한 단절을 가속화시킬 수 있다. 이러한 맥락에서 사회문화적 교류가 창출하는 다양한 가치의 중요성은 더욱 커지고 있다.

코로나19 팬데믹의 가장 중요한 영향 중 하나는 복잡성과 변동성이 증대되고 있다는 점이다. 미·중 경쟁은 전방위적으로 심화되는 가운데 자국중심주의와 다자주의가 혼재 하면서 국제정치적 복잡성은 증대하고 있다. 경제적으로 코로나19 팬데믹 종식이 요원 한 가운데 주요국의 경제부진과 교역 둔화, 경제적 양극화 심화, 재정지출 확대와 일자 리 감소현상이 두드러지게 나타나고 있다. 사회문화적으로는 초개인화 현상, 사회적 불 평등 심화, 계층 간 갈등 심화하는 가운데 초연결·초지능·초실감 등 4 차 산업혁명의 기 술적 발전이 가속화되면서 사회 전반에 영향을 미치고 있다.

이러한 변화 속에서 국제적 관계 개선과 신뢰 구축을 위한 국제문화교류의 중요성은 더욱 커지고 있다. 특히, 코로나19 팬데믹 이후 사회문화적 변화가 빠르게 전개되면서 국제문화교류의 뱡향 재설정에 대한 고민이 필요한 시점이다. 이러한 맥락에서 문화체육 관광부는 '제1차 국제문화교류 진흥 종합계획(2018-2022)'을 2020년 12월 개정하였 다. 개정된 종합계획에서는 정책목표를 $\mathbf{\Delta}$ 전략적·체계적 국제문화교류, $\boldsymbol{\Delta}$ 국제문화교류 의 '새로운 기준' 대응, $\boldsymbol{\Delta}$ 국제문화교류 생태계 조성 등으로 수정하였다. 국제문화교류 사업을 수행하고 있는 다른 기관들의 경우, 새로운 상황을 맞아 국제문화교류 사업이 중단된 경우도 있지만, 대체로 비대면으로 전환하는 등 다양한 방식으로 사업의 지속적 인 추진을 위해 노력하고 있다.

다른 주요국의 경우, 코로나19 상황에 대응하여 국제문화교류 정책 전반에 대하여 수 정하거나 체계적인 재정립을 준비하고 있는 경우를 찾기 어렵다. 대부분의 주요국은 코 로나19 팬데믹 상황과 이에 대한 대응이 문화창조분야와 종사자들에게 미치는 부정적 영향을 최소화하기 위하여 긴급대응조치들을 실시하고 있으며, 국제문화교류 정책 역시 지속적 추진을 위해 노력하고 있다. 코로나19 이후 주요국 국제문화교류의 방향 재설정 이 여전히 불투명한 가운데 한국 국제문화교류 정책의 방향을 어떻게 수립할 것인지에 대한 창의적 고민이 필요하다. 


\section{2. 정책추진 필요성}

국제문화교류를 활성화하고 정책 효과성을 제고하기 위해서는 국내외 환경 변화에 조 응하는 국제문화교류의 방향을 제시해야 한다. 무엇보다 미국과 중국의 경쟁이 본격화되 는 국제정세 속에서 한국은 정치·외교적으로 쉽지 않은 선택을 해야 할 상황들에 놓일 가능성이 증가하고 있다. 물론 전통적인 외교와 대화를 통해서 이러한 상황을 지혜롭게 헤쳐나가는 것이 중요하다. 하지만, 이러한 상황에서 전통적인 외교방식의 한계를 극복 하고 그 효과성을 제고하기 위한 국제문화교류의 중요성은 더욱 두드러진다. 즉, 대미, 대중 외교정책도 중요하지만, 한국에게 우호적인 국제사회의 여론을 형성하고 이를 활용 하는 방안이 효과적일 수 있다. 공공외교의 중요한 축을 차지하는 문화공공외교와 많은 부분을 공유하는 국제문화교류는 대상 국가의 국민을 대상으로 수행됨에 따라 한국문화 에 대해 매력을 느끼고 호감을 갖게 하며, 한국문화와 상품에 대한 소비를 자극하고, 한 국 방문을 고려하게 만들 수 있다. 이는 장기적으로 강대국의 외교적 압박을 완화시키고 나 회피할 수 있는 중요한 기반을 제공할 수 있으며, 중견국가, 개발도상국 등 국제사회 의 많은 파트너들과 친선·동반관계를 형성하고 유지·강화하는데 기여할 것이다.

문화체육관광부는 ‘제1차 국제문화교류 진흥 종합계획(2018-2022)'을 2020년 12월 개정하였다. 개정된 종합계획에서 국제문화교류의 '새로운 기준' 대응을 정책목표로 제 시하였다. 국제문화교류의 새로운 기준은 코로나 상황에 따른 단기적, 기술적 대응이 아 닌 국제문화교류 역할의 새로운 정립과 한국의 외교정책 중 국제문화교류의 중요성과 의의를 고려한 전략적 기준으로 정립되어야 한다.

코로나19 팬데믹 상황으로 인한 국가 간 교류의 어려움은 역설적으로 국제문화교류의 지속가능성이 중요함을 보여주고 있다. 코로나19로 인하여 직접적이 대면 교류에 대한 어려움이 지속되고 있지만, 문화적 관심은 더욱 증가하고 있다. 최근 OTT 수요의 급증과 다른 국가의 문화상품에 대한 관심 증가는 이를 잘 보여준다. 즉, 문화분야에서의 디지털 기술이 보다 적극적으로 활용되는 현상을 고려하였을 때, 수요에 수동적으로 대응하기보다 는 적극적으로 수요를 창출하는 국제문화교류 정책의 전환을 고려할 필요가 있다.

이를 위해서는 국제문화교류 체계 전반에 대한 검토가 중요하다. 문화체육관광부는 국제문화교류 진흥 종합계획을 수정하면서 상황변화에 적극적으로 대처하기 위해 노력 하고 있지만, 국제문화교류 사업은 문화체육관광부 산하기관 뿐만이 아니라 다양한 주체 
들에 의해 수행되고 있다. 그리고 민간 영역에서도 많은 교류 사업들이 진행되고 있다. 이러한 다양한 주체들에 의한 수많은 국제문화교류 사업들이 각자의 사업 목적에 맞게 수행되고 있는지, 사업 간 목적이 충돌하거나 상위 정책목표와의 정합성은 있는지 등에 대한 체계적 관리는 부재하다. 물론 국제문화교류 사업의 다양성 역시 중요한 요소이지 만, 다양성에 대한 강조가 체계적 관리의 부재를 정당화하기는 어렵다. 특히 국민의 세 금을 사용하는 정부부처와 공공기관의 국제문화교류 사업은 대내적 책무성 제고라는 점 에서도 관리가 필요하다. 국제문화교류 사업의 지속적인 성장을 위한 성과관리체계 구축 은 전문가 조사에서도 그 필요성이 인정되고 있다.

국제문화교류 사업이 다른 사업들과 다른 가장 중요한 특징은 정책의 주요 대상이 대 상 국가의 국민이라는 점이다. 따라서, 국제문화교류의 콘텐츠는 한국적인 것이되 보편 적 가치를 지향하였을 때, 국제문화교류에 대한 반감은 줄어들고 정책의 효과성은 제고 될 것이다. 즉, 국제문화교류의 개별 사업은 각각의 사업 목표가 있지만, 보편적인 가치 를 내재하였을 때 사업 간 정합성과 시너지 효과도 높아질 것이고, 대상 국민의 수용도 역시 향상될 것이다. 나아가 국제문화교류를 통해 보편적 가치를 지향함으로써 불확실성 과 변동성이 높은 국제정세에 흔들리지 않고 일관된 메시지를 지속가능하게 전달할 수 있다. 이를 통해 한국의 국제문화교류 정책과 사업들이 국제사회에서 통용되는 보편적 가치와 문화적 다양성에 기여하는 모범적이고 따라하고 싶은 정책과 사업들로 자리매김 할 수 있을 것이다.

이를 위해서는 코로나 19 팬데믹의 영향으로 인한 충격으로부터 국내 문화예술분야의 회복과 디지털 전환에 대한 지원과 역량 강화가 매우 중요하다. 문화예술분야의 특성 상 코로나 19 로 인해서 문화예술분야 종사자의 직업 안정성이 크게 저해되었는데 이러한 상황이 지속되어 임계점을 넘어선다면 코로나19 이전 수준으로 회복하기 어려울 수 있 다. 많은 주요국이 문화예술분야 및 종사자에 대한 다양한 재정적, 제도적 지원을 통해 회복탄력성을 높이는데 초점을 두는 이유도 이러한 문화예술분야의 특성에 기인한다. 따 라서, 문화예술분야 종사자에 대한 재정적, 제도적 지원을 통해 지속가능한 국제문화교 류의 인적 토대를 강화하여야 한다. 동시에 디지털 기술을 국제문화교류에 적극 활용하 기 위한 역량 강화와 이에 대한 적극적 지원이 필요하다. 한국의 소프트파워를 구성하는 중요한 요소 중 하나는 ICT기술 발전이라는 점에서 문화와 디지털 기술의 결합이야말로 포스트/위드-코로나 19 시대 국제문화교류의 새로운 가능성을 열어줄 것이다. 
마지막으로, 국제문화교류 사업을 위한 다양한 파트너십 구축과 활용을 통해 민간과 공공부문의 장점을 결합하여 시너지 효과를 추구하여야 한다. 향후 국제문화교류의 다양 한 방안들을 모색하고 실험하기 위해서는 새로운 창발적 아이디어와 실패를 두려워하지 않은 도전 정신이 필요하다. 이를 위해서는 민간부문의 역할이 매우 중요하며, 공공부문 은 이에 대한 체계적 지원을 통해서 국제문화교류 사업이 추구하는 정책 목표를 달성할 수 있을 것이다. 민관파트너십을 통해서 국제문화교류 대상 국가와 국민의 한국 국제문 화교류 사업의 체감도와 호감도 그리고 한국 국민의 사업 및 그 효과성에 대한 긍정적 인식을 기반으로 했을 때, 한국 국제문화교류 사업의 지속가능성은 배가될 수 있을 것이다. 다음 절에서는 코로나19 이후 국제문화교류 활성화를 위한 정책과제를 제안한다. 이를 위해 정책과제의 시간적 범위와 정책 수단을 기준으로 구분하면 다음의 그림과 같다.

〈표 5-1〉 국제문화교류 정책과제

\begin{tabular}{|c|c|c|c|}
\hline & & \multicolumn{2}{|c|}{ 시간적 범위 } \\
\hline & & 단기 & 중장기 \\
\hline & 재정적 & 긴급금융지원 & 국제문화교류 민관협력 투자펀드 조성 \\
\hline $\begin{array}{l}\text { 정책 } \\
\text { 수단 }\end{array}$ & 법/제도적 & $\begin{array}{l}\text { 국제문화교류 관련 국내 기반 조성 } \\
\text { 온라인 국제문화교류 인프라 지원 } \\
\text { 한국문화체험 Kit 활용 } \\
\text { 메타버스 구축을 통한 국제문화교류의 디 } \\
\text { 지털전환 선도 }\end{array}$ & $\begin{array}{l}\text { 가치기반 국제문화교류를 위한 제도적 노력 } \\
\text { 문화ODA 확대와 문화 주류화 } \\
\text { 민관파트너십 강화 } \\
\text { 한국국제문화교류 플랫폼 구축 } \\
\text { 국제문화교류 성과관리체계 구축 }\end{array}$ \\
\hline
\end{tabular}




\section{제2절 정책과제 제안}

\section{1. 대전환기 가치기반 국제문화교류}

\section{가. 국제문화교류를 통한 공유가치의 창출}

국가 간 경쟁이 심해지고, 자국중심주의가 강화되는 세계질서와 포스트-코로나19 팬 데믹 상황을 고려하였을 때, 국제문화교류의 뱡향과 내용을 예단하기는 어렵다. 즉, 기 존의 국제문화교류가 세계화라는 맥락에서 진행되었다면, 미래의 국제문화교류는 탈세 계화(de-globalization)이라는 흐름 속에서 전개될 가능성이 높기 때문에 이에 대한 고 려가 필요하다. 세계화는 미국 중심의 단일 질서 하에서 이루어진 것이다. 앞으로 펼쳐 진 미중 경쟁 구도 속에서의 세계적 질서의 흐름은 과거 다를 수 밖에 없다. 이러한 흐름 은 자국 문화에 대한 강조, 문화를 통한 민족적·집단적 정체성 제고, 민족주의적 경향과 함께 할 가능성이 높다. 이러한 대전환기라는 환경에서는 보다 보편적인 가치에 기반을 둔 국제문화교류를 진행하여야 한다.

국제문화교류의 새로운 방향 설정을 위해서는 일회적.단편적이고 이벤트성이 짙은 국 제문화교류를 넘어선 전략적이고 지속가능한 국제문화교류에 대한 사고의 전환이 필요 하다. 이를 위해서는 우리나라의 국제문화교류가 추구하는 가치(value)는 무엇이며, 앞 으로 추구해야 할 가치는 무엇인가에 대한 고민을 필요로 한다. 물론 국제문화교류는 우리나라가 자랑할 만한 우리 전통의 문화적 가치를 알리고, 다양한 문화적 유산과 현대 적 변용에 대하여 친근감을 갖게 한다는 의미에서 중요한 가치를 갖고 있다. 하지만, 세 계질서가 큰 변동을 보이며, 자국중심주의가 강화되는 맥락에서는 자국의 문화적 가치를 알리고 경험하게 하는 기존의 방식에는 한계가 있을 수 있다.

따라서 대전환기 국제문화교류는 가치기반(value-based) 국제문화교류가 되어야 하 며, 앞으로 국제문화교류는 한국의 문화적 가치와 보편적인 가치(universal values)가 
융합된 가치에 기반을 둘 필요가 있다. 즉, 우리나라의 문화적, 역사적 가치와 더불어 문화교류의 대상과 상호 공유할 수 있는 보편적 가치는 무엇인가에 대한 논의와 문화적 실천이 중요하다.

국제문화교류의 기반이 될 수 있는 보편적 가치는 다양할 수 있다. 다양성, 상호존중 등이 제시될 수 있지만, 이는 문화교류의 원칙이자 방식이지 함께 추구해야 할 가치라고 보기는 어렵다. 이를 위한 좋은 접근법 중 하나는 지구적 차원에서 형성된 국제규범 (global norm)을 준용하는 것이다. 오늘날 가장 중요한 국제규범 중 하나는 유엔 주도 로 설정된 지속가능발전목표(Sustainable Development Goals, SDGs)의 토대를 제공 하는 기본 가치인 $5 \mathrm{Ps}$, 즉, 인간(people), 지구·환경(planet), 번영(prosperity), 평화 (peace), 파트너십(partnership)이다. 2015년 제70차 UN 총회에서는 192개 유엔 회 원국의 만장일치로 SDGs를 채택하였으며, 이는 다섯 개 영역(5Ps)에서 우선적으로 달 성해야 할 17 개 목표와 169 개 세부 목표를 제시하였다. 이는 수원국 뿐만 아니라, 모든 이해당사자가 공동으로 추구해야 할 가치와 규범으로 자리 잡았다.

〈표 5-2〉 5Ps와 SDGs

\begin{tabular}{|c|c|c|}
\hline 기본정신/가치 & 목표 & 내용 \\
\hline \multirow{6}{*}{$\begin{array}{c}\text { 인간 } \\
\text { (People) }\end{array}$} & 1 & No Poverty, "모든 곳에서 모든 형태의 빈곤 종식" \\
\hline & 2 & Zero Hunger, "기아 종식, 식량 안보와 개선된 영양상태의 달성, 지속 가능한 농업 강화" \\
\hline & 3 & Good Health and Well-Being, "모든 연령층을 위한 건강한 삶 보장과 복지 증진" \\
\hline & 4 & $\begin{array}{l}\text { Quality Education, “모두를 위한 포용적이고 공평한 양질의 교육 보장 및 평생학습 기 } \\
\text { 회 증진” }\end{array}$ \\
\hline & 5 & Gender Equality, "성평등 달성과 모든 여성 및 여아의 권익신장" \\
\hline & 6 & $\begin{array}{l}\text { Clean Water and Sanitation, "모두를 위한 물과 위생의 이용가능성과 지속가능한 관 } \\
\text { 리 보장" }\end{array}$ \\
\hline \multirow{5}{*}{$\begin{array}{c}\text { 지구 } \\
\text { (Planet) }\end{array}$} & 7 & $\begin{array}{l}\text { Affordable and Clean Energy, "적정한 가격에 신뢰할 수 있고 지속가능한 현대적인 } \\
\text { 에너지에 대한 접근 보장" }\end{array}$ \\
\hline & 12 & Responsible Consumption and Production, "지속가능한 소비와 생산 양식의 보장" \\
\hline & 13 & Climate Action, "기후변화와 그로 인한 영향에 맞서기 위한 긴급 대응" \\
\hline & 14 & $\begin{array}{l}\text { Life Below Water, "지속가능발전을 위한 대양, 바다, 해양자원의 보전과 지속가능한 } \\
\text { 이용" }\end{array}$ \\
\hline & 15 & $\begin{array}{l}\text { Life on Land, "육상생태계의 지속가능한 보호·복원·증진, 숲의 지속가능한 관리, } \\
\text { 사막화 방지, 토지황폐화의 중지와 회복, 생물다양성 손실 중단" }\end{array}$ \\
\hline \begin{tabular}{c|c} 
번영 \\
(Prosperity)
\end{tabular} & 8 & $\begin{array}{l}\text { Decent Work and Economic Growth, "포용적이고 지속가능한 경제성장, 완전하고 } \\
\text { 생산적인 고용과 모두를 위한 양질의 일자리 증진" }\end{array}$ \\
\hline
\end{tabular}




\begin{tabular}{c|c|l}
\hline 기본정신/가치 & 목표 & \multicolumn{1}{c}{ 내용 } \\
\hline & 9 & $\begin{array}{l}\text { Industry, Innovation and Infrastructure, “회복력 있는 사회기반시설 구축, 포용적이 } \\
\text { 고 지속가능한 산업화 증진과 혁신 도모” }\end{array}$ \\
\cline { 2 - 4 } & 10 & Reduced Inequalities, “국내 및 국가 간 불평등 감소” \\
\cline { 2 - 4 } & 11 & $\begin{array}{l}\text { Sustainable Cities and Communities, “포용적이고 안전하며 회복력 있고 지속가능 } \\
\text { 한 도시와 주거지 조성” }\end{array}$ \\
\hline $\begin{array}{c}\text { 평화 } \\
\text { (Peace) }\end{array}$ & 16 & $\begin{array}{l}\text { Peace, Justice and Strong Institutions, "지속가능발전을 위한 평화롭고 포용적인 } \\
\text { 사회 증진, 모두에게 정의를 보장, 모든 수준에서 효과적이며 책임감 있고 포용적인 제도 } \\
\text { 구축" }\end{array}$ \\
\hline $\begin{array}{c}\text { 파트너십 } \\
\text { (Partnership) }\end{array}$ & 17 & $\begin{array}{l}\text { Partnerships for the Goals, "이행수단 강화와 지속가능발전을 위한 글로벌 파트너십 } \\
\text { 의 활성화” }\end{array}$ \\
\hline
\end{tabular}

출처: 지속가능발전포털(http://ncsd.go.kr/unsdgs?content=2)

UN SDGs는 개발도상국의 경제, 사회발전을 넘어서 인류 공동의 지속가능한 발전을 목표로 제시하고 있으며, 보편적 가치라고 할 수 있는 5Ps를 기본 토대로 제공한다는 점에서 국제문화교류가 추구해야 할 가치와도 일맥상통한다. 구체적으로 UN SDGs 17개 목표를 살펴보았을 때, 개별 목표에서 문화와 명시적·직접적으로 관련된 목표는 제시되지 않았지만, 세부목표 4.7, 8.3, 8.9, 11.4, 12.b 등은 문화적 요소가 발전에 중요함을 보여 준다. 나아가 문화적 권리, 유산, 다양성, 창의성 등이 인간발전, 지속가능한 발전을 위한 핵심요소라는 점에서 문화적 측면은 UN SDGs 달성을 위해서 필수적이다. ${ }^{172)}$

〈표 5-3〉 문화와 관련된 SDGs 세부목표

\begin{tabular}{c|c|l}
\hline 목표 & SDGs & \multicolumn{1}{c}{ 세부목표 } \\
\hline \multirow{6}{*}{4} & $\begin{array}{l}\text { [세부목표 4.7] 2030년까지 모든 학습자들이 지속가능발전 및 지속가능 생활 } \\
\text { 방식, 인권, 성평등, 평화와 비폭력 문화증진, 세계시민의식, 문화다양성 및 지 } \\
\text { 속가능발전을 위한 문화의 기여에 대한 교육을 통해, 지속가능발전을 증진하 } \\
\text { Quality Education: } \\
\text { Ensure inclusive } \\
\text { and equitable } \\
\text { quality education } \\
\text { and promote } \\
\text { lifelong learning } \\
\text { opportunities for all }\end{array}$ & $\begin{array}{l}\text { By 2030, ensure that all learners acquire the knowledge and skills } \\
\text { needed to promote sustainable development, including, among } \\
\text { others, through education for sustainable development and } \\
\text { sustainable lifestyles, human rights, gender equality, promotion of } \\
\text { a culture of peace and non-violence, global citizenship and } \\
\text { appreciation of cultural diversity and of culture's contribution to } \\
\text { sustainable development. }\end{array}$ \\
\hline
\end{tabular}

172) United Cities and Local Governments. 2018. "Culture in the Sustainable Development Goals: A Guide for Local Action" 


\begin{tabular}{|c|c|c|}
\hline 목표 & SDGs & 세부목표 \\
\hline \multirow[t]{2}{*}{8} & \multirow{2}{*}{$\begin{array}{l}\text { Decent Work and } \\
\text { Economic Growth: } \\
\text { Promote sustained, } \\
\text { inclusive and } \\
\text { sustainable } \\
\text { economic growth, } \\
\text { full and productive } \\
\text { employment and } \\
\text { decent work for all }\end{array}$} & $\begin{array}{l}\text { [세부목표 8.3] 생산 활동, 양질의 일자리 창출, 기업가 정신, 창의성과 혁신을 } \\
\text { 지원하는 개발지향적 정책을 진흥하고 금융서비스에 대한 접근 확대를 포함하 } \\
\text { 여 소규모 비즈니스 및 중소기업의 형성과 성장을 장려한다. } \\
\text { Promote development-oriented policies that support productive } \\
\text { activities, decent job creation, entrepreneurship, creativity and } \\
\text { innovation, and encourage the formalization and growth of micro-, } \\
\text { small- and medium-sized enterprises, including through access to } \\
\text { financial services }\end{array}$ \\
\hline & & $\begin{array}{l}\text { [세부목표 8.9] 2030년까지 지역의 고유문화와 특산품을 알리고 일자리 창출 } \\
\text { 에 기여하는 지속가능한 관광 진흥 정책을 개발하고 이행한다. } \\
\text { By 2030, devise and implement policies to promote sustainable } \\
\text { tourism that creates jobs and promotes local culture and products }\end{array}$ \\
\hline 11 & $\begin{array}{l}\text { Sustainable Cities } \\
\text { and Communities: } \\
\text { Make cities and } \\
\text { human settlements } \\
\text { inclusive, safe, } \\
\text { resilient and } \\
\text { sustainable }\end{array}$ & $\begin{array}{l}\text { [세부목표 11.4] 세계 문화유산과 자연유산 보호를 위한 노력을 강화한다. } \\
\text { Strengthen efforts to protect and safeguard the world's cultural and } \\
\text { natural heritage }\end{array}$ \\
\hline 12 & $\begin{array}{l}\text { Responsible } \\
\text { Consumption and } \\
\text { Production: } \\
\text { Ensure sustainable } \\
\text { consumption and } \\
\text { production } \\
\text { patterns }\end{array}$ & $\begin{array}{l}\text { [세부목표 12.b] 일자리를 창출하고 지역 문화와 특산품을 알리는 지속가능 } \\
\text { 관광으로 인한 지속가능발전 영향을 모니터링하기 위한 수단을 개발하고 이행 } \\
\text { 한다. } \\
\text { Develop and implement tools to monitor sustainable development } \\
\text { impacts for sustainable tourism that creates jobs and promotes } \\
\text { local culture and products }\end{array}$ \\
\hline
\end{tabular}

출처: 환경부, "유엔 지속가능발전목표"

이러한 점에서 우리나라의 국제문화교류 역시 이러한 보편적 가치를 지향하며, 개별 사업들이 어떻게 이러한 가치들과 연계되고 어떻게 이러한 가치들을 제고하는데 기여하 는지를 제시할 필요가 있다. 특히, 국제문화교류는 행위자들 사이의 간주관적인 (inter-subjective) 이해를 증진하고, 이러한 상호이해를 바탕으로 새로운 가치를 창출 한다는 점에서 우리나라와 대상 국가 시민과 함께 할 수 있는 현시대를 대표하는 핵심 가치에 기반을 두어야 한다. 미래예측이 어렵고, 자국 문화를 강조하며 변동성이 큰 대 전환의 시기일수록 보편적 가치에 기반을 둔 국제문화교류가 필요하다는 것이다. 따라 서, UN SDGs.5Ps와 우리나라의 국제문화교류 및 이를 위한 개별 사업이 어떻게 연계 될 수 있는지를 밝히는 것은 대전환기 국제문화교류의 방향 설정에 기여할 것이다. 
구체적으로는 국제문화교류의 개별 사업과 보편적 가치와의 연계성을 명시적으로 검 토하고 확인하는 것이다. 현재 한국 공공기관들의 국제문화교류 사업은 각 기관별 고유 사업 목적에 맞추어 교류사업이 형성되어 있다. 그 사업목적에 맞게 진행하면서, UN $\mathrm{SDGs} \cdot 5 \mathrm{Ps}$ 의 보편적 원칙에 맞는지 검토해보고 이를 적용하여 사업의 질적 전환을 추구 하는 작업들이 필요할 것으로 보인다. 나아가, 개별 사업이 추구하거나 기여할 것으로 기대되는 보편적 가치를 사업계획 수립 단계에서 고려하고, 평가 지표로 활용하는 방식 을 고려할 수 있다.

\section{나. 보편적 가치 추구를 위한 국내 기반 조성}

가치기반 국제문화교류를 위해서는 이를 위한 국내 기반 조성이 필요하다. 즉, 대외적 문화교류에서는 보편적인 공동의 가치 창출과 추구를 강조하면서, 대내적으로는 이러한 가치에 반하는 관행이나 제도가 여전히 남아있다면, 국제문화교류의 효과성과 신뢰성 (credibility)이 저하될 것이다.

특히, 코로나19 팬데믹 상황과 포스트-코로나19 상황을 고려한다면, 보편적 가치의 내재화는 매우 중요하다. 즉, 국제문화교류를 진행함에 있어서 기존의 대면 방식이 어려 운 상황에서는 교류를 통한 상호이해의 정도나 깊이가 상이할 수 있다. 즉, 대면 방식을 통한 국제문화교류는 친밀한 접촉과 반복을 통해 우호적 태도, 호감이 형성될 수 있는 반면, 비대면 방식이 많이 활용될 포스트-코로나19 시대에는 상대 문화에 대한 부족한 이해나 서투른 소통 방식으로 인해 의도치 않은 결과를 가져올 수 있다.

또한, 자국중심주의가 강해지는 상황과 지속적인 문화교류를 통한 우리나라의 문화와 상대 문화에 대한 인식 제고의 기회가 줄어드는 상황에서 우리나라의 국제문화교류는 한류 확산이라는 일방적 문화 전파 혹은 메시지 전달로 받아들여질 수 있다. 따라서 글 로벌 시민과 교류하는 데 있어서 우리의 문화가 보편적 가치와 다르지 않음을 보여줌과 동시에 우리 내부의 규범과 관행 역시 보편적 가치와 일치(align)하여야 한다.

이는 보편적 가치를 내재화하지 않은 국내의 문화적 현실은 국제문화교류의 효과를 저해할 수 있다는 우려와 연계되어 있다. 한류 현상이 지속되면서, '반한' 감정이나 반 한류 정서 역시 지속되고, (포스트-)코로나19 상황에서 이러한 경향이 강화될 가능성을 배제할 수 없다. 무엇보다 국제문화교류가 온라인, 디지털화함에 따라서 그 긍정적 혹은 
부정적 영향력·파급력은 시간과 공간을 초월할 수 있으며, 특히 부정적 영향력·파급력이 확대 재생산되는 현상이 빈번하게 발생한다. 따라서 국제문화교류를 통해서 추구하는 핵 심 가치, 메시지와 상반된 국내 규범, 관행, 행동 등이 온라인상에서 영원히 저장되고 언제든 소환될 수 있다는 점에서 세심한 주의가 필요하다.

결국, 코로나19 시대와 그 이후를 바라보면서, 국제문화교류의 근간이라고 할 수 있 는 국내의 문화 관련 제도, 관행에 대한 정비가 필요하다. 문화예술분야 종사자의 삶의 질을 제고하고, 다양한 권리를 보장하며, 불평등하고 불공정한 관행을 철폐하고, 창의적 이고 혁신적인 아이디어 창출을 권장하고 보장하며, 환경 친화적인 규범, 준칙, 관행, 행위 등이 제도화될 수 있도록 노력해야 한다. 이를 위해서 문화예술 관계자들의 보편적 가치에 대한 인식 제고 노력 역시 진행될 필요가 있다. 전문가 설문조사에 따르면, "코로 나19 이후 국제문화교류 활성화를 위한 정책의 필요성" 설문 항목에서 가장 많은 응답 자(93\%)가 '국제문화교류 국내체계 정비'가 필요하다고 답하였다. 이는 국제문화교류를 위해서는 일시적인 지원도 중요하지만 국내체계를 근본적으로 재정비하는 것이 중요함 을 보여준다.

\section{다. 문화와 ODA의 연계 강화: 문화 $\mathrm{ODA}$ 확대와 문화 주류화}

국제문화교류에서 $\mathrm{ODA}$ 는 매우 중요한 구성요소이다. 하지만, 한국의 국제문화교류 사업에서 $\mathrm{ODA}$ 사업 특히 문화ODA 사업은 중요하게 다루어지지 않고 있다. 국제문화 교류, 특히 개발도상국과의 국제문화교류를 위해서는 문화 부문 공적개발원조(ODA)의 양적, 질적 제고가 필요하다. 먼저, 문화 $\mathrm{ODA}$ 의 양적 확대가 필요하다.

〈표 5-4〉 한국의 문화 ODA 규모(2006 2019)

\begin{tabular}{|c|c|c|c|c|c|c|c|c|c|c|c|c|c|c|}
\hline & 2006 & 2007 & 2008 & 2009 & 2010 & 2011 & 2012 & 2013 & 2014 & 2015 & 2016 & 2017 & 2018 & 2019 \\
\hline 총액 & 411.431 & 513.582 & 656.928 & 773.645 & 1035.939 & 1086.326 & 1299.727 & |1395.847 & 1429.395 & 1560.727 & 1644.485 & \begin{tabular}{l|l}
1644.29 \\
\end{tabular} & 1786.654 & 2045.889 \\
\hline $\begin{array}{c}\text { 문화와 } \\
\text { 레크리에이션 } \\
\end{array}$ & 6.037 & 1.723 & 4.267 & 4.113 & 3.062 & 5.924 & 7.445 & $\mid$\begin{tabular}{|l}
$\mid 11.824$ \\
\end{tabular} & 19.978 & 17.283 & 17.986 & 17.658 & 25.875 & 22.48 \\
\hline $\begin{array}{l}\text { 관광정책과 } \\
\text { 행정관리 }\end{array}$ & 0.207 & 1.168 & 1.404 & 0.454 & 0.312 & 0.45 & 1.281 & 1.095 & 2.53 & 1.61 & 1.289 & 2.407 & 2.882 & 3.84 \\
\hline 유산보존 & & & 0.082 & & & & 1.328 & 0.881 & 0.064 & 1.145 & 0.759 & 0.657 & 0.794 & 1.901 \\
\hline $\begin{array}{l}\text { 문화ODA } \\
\text { 총액 }\end{array}$ & 6.244 & 2.891 & 5.753 & 4.567 & 3.374 & 6.374 & $\mid 10.054$ & 13.8 & 22.572 & 20.038 & 20.034 & 20.722 & 29.551 & 28.221 \\
\hline
\end{tabular}




\begin{tabular}{c|c|c|c|c|c|c|c|c|c|c|c|c|c|c}
\hline & 2006 & 2007 & 2008 & 2009 & 2010 & 2011 & 2012 & 2013 & 2014 & 2015 & 2016 & 2017 & 2018 & 2019 \\
\hline $\begin{array}{c}\text { 문화ODA/ } \\
\text { 전체ODA } \\
\text { 비중 }\end{array}$ & $1.52 \%$ & $0.56 \%$ & $0.88 \%$ & $0.59 \%$ & $0.33 \%$ & $0.59 \%$ & $0.77 \%$ & $0.99 \%$ & $1.58 \%$ & $1.28 \%$ & $1.22 \%$ & $1.26 \%$ & $1.65 \%$ & $1.38 \%$ \\
\hline
\end{tabular}

출처: OECD CRS

여기에서 우리나라의 문화 ODA란 “경제발전과 문화발전을 동시에 이룬 한국의 경험 과 지식을 활용하여 개발협력국의 문화발전과 지속가능한 발전에 기여하는 공적개발원 조”로 정의될 수 있다.173) 이러한 정의를 바탕으로, $\mathrm{OECD}$ 개발원조위원회(Development Assistance Committee, DAC) 공여국 보고체계(Creditor Reporting System, CRS) 통계자료 중 문화 $\mathrm{ODA}$ 로 간주될 수 있는 3개의 하위분야(문화 및 레크리에이션, 관광 정책과 행정관리, 유산보존)의 총합이 문화 부문 $\mathrm{ODA}$ 로 간주될 수 있다. 이러한 기준을 적용하였을 때, 2006년 2019년의 기간 동안 우리나라의 ODA는 17,284.865백만 달 러(도착액 기준, 2019 USD)이며, 이중 약 $1.12 \%$ 에 해당하는 194.195백만 달러가 문화 분야 ODA에 지원되었다.

[그림 5-1] 한국의 문화 ODA 규모(2006 2019)

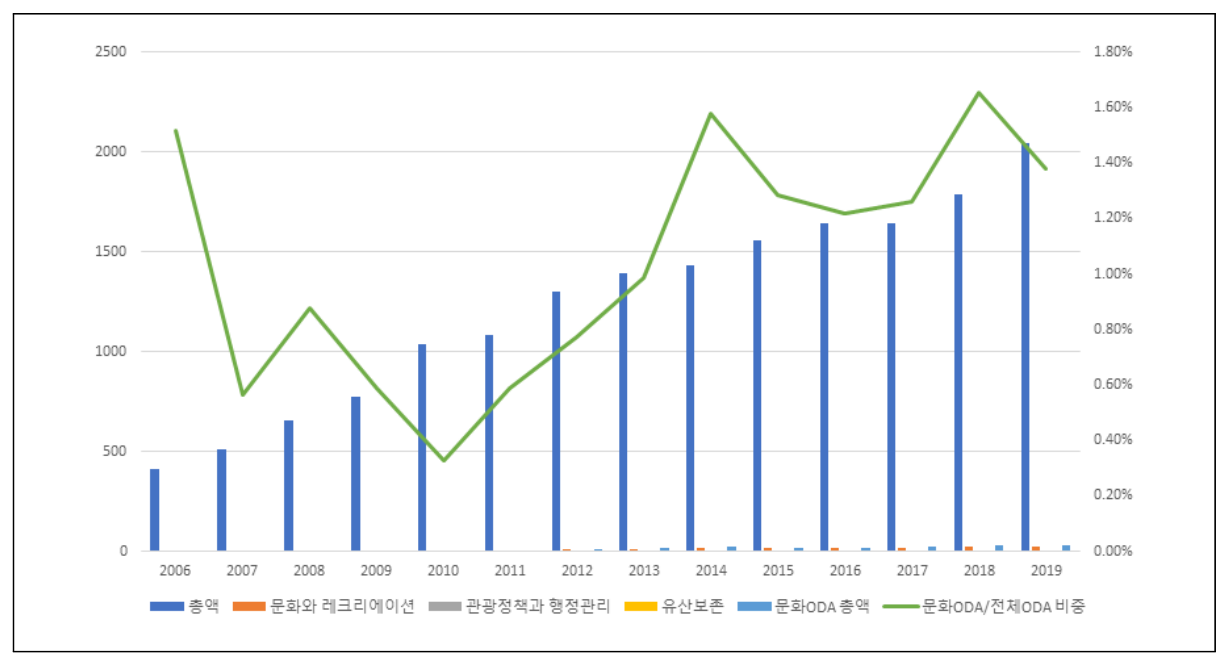

출처: OECD CRS

173) 이성우·이영유. 2021. “한국 국제개발협력과 문화 ODA." 문화정책논총, 35(1), p.198. 
문화 ODA의 경우, 지난 10년(2010년 2019년) 연평균 규모가 17.474백만 달러에 불과하며, 다자원조를 고려하면 문화 부문 양자 $\mathrm{ODA}$ 은 매우 소규모이다. 또한, 소수의 수원국만 문화 $\mathrm{ODA}$ 의 대상이라는 점에서도 우리나라의 문화 ODA는 한계가 있다. 하 지만, 향후 우리나라의 ODA 규모 증가 계획을 고려하였을 때, 문화 부문 ODA 규모 역시 증가될 필요가 있다. 2021년 1월 20일 제36차 국제개발협력위원회에 의해서 의결 된 「제3차 국제개발협력 기본계획(2021 2025)」는 향후 5년 간 ODA가 나아갈 방향을 제시하고 있는데, 이 가운데 국제사회에 대한 중요한 언약 중 하나는 원조 규모의 확대 이다. 우리나라 정부는 UN SDGs가 종료되는 2030년까지 총 ODA 규모를 2019년(3.2 조 원) 대비 2 배 이상 수준으로 확대하기로 공언하였다. 이러한 점에서 문화 부문 ODA 도 2030 년까지 2 배 이상으로 증가될 필요가 있다.「제 1 차 국제문화교류 진흥 종합계획 (2018 2022) 개정판」에 따르면, 개발도상국 문화역량 강화 사업을 확대하기 위하여 문 화 $\mathrm{ODA}$ 신규 사업을 발굴하고, 문화기반 구축을 위한 프로젝트형 사업을 추진하는 등 다양한 사업이 기획, 실행되고 있으나, 문화 $\mathrm{ODA}$ 규모 확대에 대한 중장기적인 고려는 부족한 것으로 보인다.

동시에 문화 $\mathrm{ODA}$ 규모에 걸맞은 질적 향상을 고려해야 한다. 이를 위해서는 국제문 화교류 전략과 문화 $\mathrm{ODA}$ 의 비전, 추진전략, 목표를 일치시키는 정책일관성(policy coherence) 제고 노력이 필요하다. 즉, 「문화 ODA 기본계획」을 수립하여, 전략적·체 계적 문화ODA 수행을 준비해야 한다. 현재 우리나라의 문화 ODA는 주로 문화체육관 광부, 문화재청, 한국국제협력단(KOICA)에 의해서 수행되고 있다. 하지만, 소규모의 문 화 $\mathrm{ODA}$ 가 다양한 사업으로 나뉘어 집행됨으로써 원조효과성을 떨어뜨린다는 점에서 원조 분절화(fragmentation)을 극복하기 위한 노력이 필요하다.

이와 더불어, 문화를 주류화(culture mainstreaming)하려는 노력이 필요하다. 즉, 우리나라 ODA 정책 및 수행의 모든 부분에 있어서 문화의 관점에서 바라보고, 이에 미 치는 영향을 고려하는 것이다. 문화는 SDGs 달성에 매우 중요한 역할을 한다. 특히 자 국중심주의와 국가 간 경쟁이 강화되고 갈등이 예상되는 현 상황을 극복하고 모든 이해 당사자(multi-stakeholder)가 공동의 목표를 달성하기 위해서는 문화적 이해에 기반을 둔 상호신뢰가 더욱 중요해진다. 「제3차 국제개발협력 기본계획(2021 2025)」의 비전 은 “협력과 연대를 통한 글로벌 가치 및 상생의 국익 실현”이다. 글로벌 가치에 기반을 두고 상생의 국익을 실현하기 위해서는 우리나라와 수원국(민) 사이의 공동의 가치를 창 
출할 필요가 있으며, 그러한 과정에서 협소하게 정의된 정치적·외교적·경제적 국익이 아 닌 문화적 상호이해에 기반을 둔 원조를 수행함으로써 원조를 통한 국익 추구에 따르는 국제사회와 국내 행위자의 우려를 불식시킬 수 있다.

구체적으로는 모든 부문의 원조사업을 기획하고, 수행하고, 평가하는데 문화와의 관 계적 함의를 고려하는 것이다. 예를 들면, 교육 부문 $\mathrm{ODA}$ 의 경우, 국제문화교류의 관점 에서 상호 간 이해를 증진할 수 있는 문화가 교육 콘텐츠에 어떻게 녹아 들어갈 수 있는 지를 고려하는 것이다. 나아가, 문화 마커(marker)를 개발하여, 각 사업이 문화의 어떠 한 부문(문화다양성, 문화/창의산업, 상호이해증진 등)과 연계되는지를 추적, 관찰, 모니 터링, 평가하는데 활용할 수 있다. 아래〈표 5-5〉는 SDGs의 각 목표와 문화가 어떻게 연계되는지를 잘 보여준다. 이러한 점에서 문화 부문 $\mathrm{ODA}$ 의 양적 규모에는 한계가 있 지만, 모든 ODA에 문화적 함의를 부여함으로써 국제문화교류와 시너지를 확보할 수 있다.

〈표 5-5〉문화와 관련된 SDGs 세부목표

\begin{tabular}{|c|c|c|}
\hline & SDGs & 문화와의 관계 \\
\hline 1 & $\begin{array}{c}\text { No Poverty, "모든 곳에서 } \\
\text { 모든 형태의 빈곤 종식" }\end{array}$ & $\begin{array}{l}\text { 문화 서비스는 기본적인 서비스이며, 따라서 모든 사람들에게 이에 대한 동 } \\
\text { 등한 접근이 보장되어야 한다. } \\
\text { 문화적 표현, 서비스, 상품, 유적지는 포괄적이고 지속가능한 경제적 발전 } \\
\text { 에 기여할 수 있다. }\end{array}$ \\
\hline 2 & \begin{tabular}{|c|} 
Zero Hunger, "기아 종식, \\
식량 안보와 개선된 \\
영양상태의 달성, 지속 \\
가능한 농업 강화"
\end{tabular} & $\begin{array}{l}\text { 종자의 유전적 다양성 등 유전 자원의 보존과 관련된 전통적 지식은 널리 } \\
\text { 알려지고 보존되어야 하며, 관련된 혜택의 공정한 분배 또한 추진되어야 한 } \\
\text { 다. }\end{array}$ \\
\hline 3 & $\begin{array}{l}\text { Good Health and } \\
\text { Well-Being, "모든 } \\
\text { 연령층을 위한 건강한 삶 } \\
\text { 보장과 복지 증진“ }\end{array}$ & $\begin{array}{l}\text { 보건 정책과 프로그램은 현지의 관습을 고려해야 하며 적절하게 전통적 보 } \\
\text { 건 시스템과 의료 행위자(practitioner)의 통합하는 등 문화적으로 적절해 } \\
\text { 야 한다(culturally-relevant). } \\
\text { 문화 생활의 참여는 다수의 연구와 사례에서 확인된 바와 같이, 건강과 웰 } \\
\text { 빙을 향상시킬 수 있다. }\end{array}$ \\
\hline 4 & $\begin{array}{c}\text { Quality Education, } \\
\text { “모두를 위한 포용적이고 } \\
\text { 공평한 양질의 교육 보장 및 } \\
\text { 평생학습 기회 증진" }\end{array}$ & $\begin{array}{l}\text { 모든 수준에서의 교육 프로그램은 문화적 다양성, 예술 교육, 언어, 지속가 } \\
\text { 능한 발전에서 문화적 측면의 역할에 대한 내용(contents)을 통합할 필요 } \\
\text { 가 있다. } \\
\text { 모든 수준의 커리큘럼 설계에서 지역 언어와 지역 관련 능력의 인식, 문화 } \\
\text { 적 이해당사자의 참여를 포함한 문화적 접근 방식이 우선시되어야 한다. 이 } \\
\text { 는 인권의 연장선이며 학생들의 동기부여와 지역사회 연계 등의 교육목표 } \\
\text { 에 기여할 수 있다. }\end{array}$ \\
\hline 5 & $\begin{array}{l}\text { Gender Equality, "성평등 } \\
\text { 달성과 모든 여성 및 여아의 } \\
\text { 권익신장" }\end{array}$ & $\begin{array}{l}\text { 양성평등은 문화생활에서도 이루어져야 한다. 여성과 소녀들이 문화생활에 } \\
\text { 적극적으로 참여하여, 각 분야에서 프로젝트와 조직을 이끌 수 있는 기회가 } \\
\text { 확장될 필요가 있다. }\end{array}$ \\
\hline
\end{tabular}




\begin{tabular}{|c|c|c|}
\hline & SDGs & 문화와의 관계 \\
\hline & & $\begin{array}{l}\text { 더 나아가 주로 여성과 소녀들이 수행하는 문화적인 관행에 대한 가시성과 } \\
\text { 인지도가 향상될 필요가 있다. } \\
\text { 성차별을 다루거나 문화생활에서 여성과 소녀의 중요한 역할을 보여주는 } \\
\text { 이야기(narrative)가 필요하다. }\end{array}$ \\
\hline 6 & \begin{tabular}{|} 
Clean Water and \\
Sanitation, “모두를 위한 \\
물과 위생의 이용가능성과 \\
지속가능한 관리 보장"
\end{tabular} & $\begin{array}{l}\text { 일부 전통 지식은 물 관련 생태계의 적절하고 지속 가능한 사용을 촉진하는 } \\
\text { 교훈을 제공할 수 있다. }\end{array}$ \\
\hline 7 & $\begin{array}{c}\text { Affordable and Clean } \\
\text { Energy, "적정한 가격에 } \\
\text { 신뢰할 수 있고 지속가능한 } \\
\text { 현대적인 에너지에 대한 } \\
\text { 접근 보장" }\end{array}$ & $\begin{array}{l}\text { 문화적 요인은 에너지 생산 및 소비 패턴에 대한 설명을 제공한다. } \\
\text { 창의적 요인들은 에너지 생산과 소비에 대한 교육 및 인식 제고 활동에 도 } \\
\text { 움을 줄 수 있다. }\end{array}$ \\
\hline 8 & \begin{tabular}{|c|} 
Decent Work and \\
Economic Growth, \\
"포용적이고 지속가능한 \\
경제성장, 완전하고 \\
생산적인 고용과 모두를 \\
위한 양질의 일자리 증진" \\
\end{tabular} & $\begin{array}{l}\text { 국제 인권에 따른 적절한 노동 조건이 보장되는 한, 문화적·창의적 부문은 } \\
\text { 포괄적이고 지속가능하며 공정한 고용의 영역이 될 수 있는 잠재력을 가지 } \\
\text { 고 있다. } \\
\text { 문화적 측면은 관광 전략에 통합될 수 있으며, 이는 문화적 정체성, 활동 } \\
\text { 및 자산의 탈맥락화(decontextualisation)를 의미하지 않으며 관련 혜택이 } \\
\text { 문화 활동에 재투자됨을 의미한다. }\end{array}$ \\
\hline 9 & \begin{tabular}{|l|} 
Industry, Innovation and \\
Infrastructure, “회복력 \\
있는 사회기반시설 구축, \\
포용적이고 지속가능한 \\
산업화 증진과 혁신 도모" \\
\end{tabular} & $\begin{array}{l}\text { 문화 인프라는 문화 생활에 참여할 수 있는 저렴하고 공정한 접근과 참여 } \\
\text { 기회를 제공하는 것으로, 모든 사람이 이용할 수 있어야 하는 우수하고, 신 } \\
\text { 뢰할 수 있으며, 지속가능하고 탄력적인 인프라의 일부이다. } \\
\text { 예술가와 크리에이티브 전문가들은 광범위한 산업 영역에서 연구, 개발 및 } \\
\text { 혁신을 목표로 하는 과정에 참여할 수 있다. }\end{array}$ \\
\hline 10 & $\begin{array}{l}\text { Reduced Inequalities, } \\
\text { "국내 및 국가 간 불평등 } \\
\text { 감소" }\end{array}$ & $\begin{array}{l}\text { 문화 참여는 연령, 성별, 장애, 인종, 민족, 출신, 종교, 경제적 또는 그 밖 } \\
\text { 의 지위에 관계없이 모든 사람을 포용하는데 기여할 수 있다. } \\
\text { 예술가와 크리에이티브 전문가는 개발도상국에 힘을 싣는 이야기의 설계 } \\
\text { (design)와 발표에 참여할 수 있다. } \\
\text { 이주에 대한 모든 접근법은 문화적 차원과 문화 간 대화를 포함해야 한다. }\end{array}$ \\
\hline 11 & \begin{tabular}{|} 
Sustainable Cities and \\
Communities, \\
"포용적이고 안전하며 \\
회복력 있고 지속가능한 \\
도시와 주거지 조성"
\end{tabular} & $\begin{array}{l}\text { 유·무형문화재 관련의 많은 유적지와 요인들이 도시에서 발견되고 있으며, } \\
\text { 지속가능한 지역발전에 중요한 역할을 하고 있다. 따라서, 문화적인 측면은 } \\
\text { 지역의 지속가능한 발전을 촉진하는 데 있어 필수적이다. } \\
\text { 녹지와 공공 공간은 문화활동의 발전을 가능하게 하며 누구나 쉽게 이에 } \\
\text { 접근할 수 있어야 한다. } \\
\text { 전통 건축 기법과 관련 지식/자료들은 기존 건물의 개보수와 새로운 건물의 } \\
\text { 설계에 대한 접근 방식을 알려줄 수 있다. } \\
\text { 문화적 요인은 교통 및 이동, 환경 사용 등을 모함한 도시 및 지역에서의 } \\
\text { 행동에 대한 정보를 제공한다. }\end{array}$ \\
\hline 12 & \begin{tabular}{|c|} 
Responsible \\
Consumption and \\
Production, "지속가능한 \\
소비와 생산 양식의 보장"
\end{tabular} & $\begin{array}{l}\text { 지속가능한 소비와 생산에 적합한 지역적, 전통적 생산물을 인식하고 인정 } \\
\text { 해야 한다. }\end{array}$ \\
\hline 13 & $\begin{array}{l}\text { Climate Action, } \\
\text { "기후변화와 그로 인한 }\end{array}$ & $\begin{array}{l}\text { 문화 활동, 전통 지식, 환경적으로 지속가능한 관습 간의 연계성이 존재하 } \\
\text { 며, 이를 발굴하고 장려해야 한다. }\end{array}$ \\
\hline
\end{tabular}




\begin{tabular}{|c|c|c|}
\hline & SDGs & 문화와의 관계 \\
\hline & $\begin{array}{l}\text { 영향에 맞서기 위한 긴급 } \\
\text { 대응" }\end{array}$ & $\begin{array}{l}\text { 크리에이티브 전문가들은 기후 변화에 대한 인식 제고 활동에 참여할 수 } \\
\text { 있다. }\end{array}$ \\
\hline 14 & \begin{tabular}{|c|} 
Life Below Water, \\
"지속가능발전을 위한 대양, \\
바다, 해양자원의 보전과 \\
지속가능한 이용"
\end{tabular} & $\begin{array}{l}\text { 일부 문화적 전통은 해양 및 해안 생태계의 지속가능한 보존과 관련되어 } \\
\text { 있으며, 이를 확인하고 보강할 필요가 있다. }\end{array}$ \\
\hline 15 & \begin{tabular}{|c|} 
Life on Land, \\
"육상생태계의 지속가능한 \\
보호·복원·증진, 숲의 \\
지속가능한 관리, 사막화 \\
방지, 토지황폐화의 중지와 \\
회복, 생물다양성 손실 \\
중단" \\
\end{tabular} & $\begin{array}{l}\text { 지역 및 전통 지식을 포함한 지상 생태계 보존과 관련된 문화적 요소들이 } \\
\text { 이 분야의 정책과 프로그램의 설계, 구현, 평가에 통합될 필요가 있다. }\end{array}$ \\
\hline 16 & $\begin{array}{l}\text { Peace, Justice and } \\
\text { Strong Institutions, } \\
\text { “지속가능발전을 위한 } \\
\text { 평화롭고 포용적인 사회 } \\
\text { 증진, 모두에게 정의를 } \\
\text { 보장, 모든 수준에서 } \\
\text { 효과적이며 책임감 있고 } \\
\text { 포용적인 제도 구축” }\end{array}$ & $\begin{array}{l}\text { 도난당한 문화재는 관련 지역사회에 반환되어야 한다. } \\
\text { 시민들은 문화정책과 프로그램의 설계, 구현, 평가에 참여할 수 있어야 한 } \\
\text { 다. } \\
\text { 도서관과 지식 센터 등의 문화 시설은 정보에 대한 접근을 활성화한다. } \\
\text { 폭력 완화와 평화 증진을 위한 전략은 문화적 요소를 포함해야 한다. }\end{array}$ \\
\hline 17 & $\begin{array}{c}\text { Partnerships for the } \\
\text { Goals, "이행수단 강화와 } \\
\text { 지속가능발전을 위한 } \\
\text { 글로벌 파트너십의 활성화" }\end{array}$ & $\begin{array}{l}\text { 2030Agenda 시행을 포함하여 지속가능한 발전을 위한 국제적, 국가적 및 } \\
\text { 지역적 전략은 문화적 차원의 통합이 필요하다. } \\
\text { 문화적 이해당사자들의 역량을 강화하여 다른 지속가능한 발전과제를 해결 } \\
\text { 할 수 있도록 해야 하며, 역량강화는 지속가능한 발전에 관여하는 다른 단 } \\
\text { 체들도 문화적 측면의 중요성을 이해할 수 있도록 해야 한다. } \\
\text { 문화 상품과 서비스를 생산하고 전달하는 문화적 이해당사자들의 역량, 특 } \\
\text { 히 덜 알려진 문화 표현을 대표하는 역랑은 강화되어야 한다. }\end{array}$ \\
\hline
\end{tabular}

출처: United Cities and Local Governments. 2018. "Culture in the Sustainable Development Goals: A Guide for Local Action"pp. 7-30.의 내용을 바탕으로 재구성

\section{2. 회복탄력성 제고를 위한 거버넌스 구축}

\section{가. 에자일 거버넌스(agile governance)를 통한 회복탄력성 제고}

코로나19 팬데믹은 문화예술분야에도 심각한 영향을 미치고 있다는 점은 주지의 사 실이다. 사회적 거리두기로 인해 문화예술공연은 취소되고, 문화예술공간에서의 전시, 공연활동이 중단됨에 따라 문화예술활동은 위축되고 문화예술분야 종사자의 소득, 직업 안정성, 그리고 삶의 질은 저하하였다. 물론 디지털 전환이라는 관점에서 새로운 기회들 
이 생겨나고 있지만, 이러한 기회를 활용하여 실질적-가시적 성과를 도출하기에는 여전 히 많은 도전이 산재해 있다.

이러한 점에서 최근 문화예술분야 회복탄력성 제고를 위한 논의는 국제문화교류에도 중요한 시사점을 제시한다. 양혜원 외 $(2020,53)$ 에 따르면, 회복탄력성에 관한 다양한 개념 정의와 논의 중에서 문화예술분야에 가장 적합한 개념으로는 위기나 충격 이전 상 태로 회복하는(bouncing back) 의미로서의 회복탄력성이 아닌, 미래 예측에 기반을 둔 능동적 적응능력으로서 “새로운 상태로 나아가는(bouncing forward) 회복탄력성” 개 념이다. 즉, 반응적(reactive)이 아닌 적극적(proactive) 역량이 필요하며, 이를 위해서 는 "i) 미션이나 조직구조와 기능은 새로운 상황에 적합해야 한다는 점, ii) 견디는 힘보 다는 적응력이 더 중요하다는 점, iii) resilience라는 개념은 중장기적 관점을 내포하고 있는 용어로서, 단기적 적응력은 오히려 중장기적 회복탄력성을 감소시킬 수 있다는 점" 이 강조된다. ${ }^{174)}$ 특히 문화예술분야는 그 자체로서 하나의 중요한 가치라는 점에서 회 복탄력성을 제고해야할 뿐만 아니라 사회 전체의 회복탄력성에 기여한다는 점에서 더 큰 사회적 가치를 창출한다.

이러한 맥락에서 코로나19 팬데믹과 같이 언제든지 닥쳐올 수 있는 충격, 위기 상황 에서 능동적으로 대응하고 새로운 모습으로 국제문화교류를 (재)구성하고 더 큰 가치를 창출하기 위해서는 새로운 거버넌스가 필요하다. 이를 위해 에자일 거버넌스 구축이 필 요하다. 즉, 변동성, 불확실성, 복잡성이 갈수록 증대되는 미래 상황에서 기민하고 민첩 하게 대응할 필요성이 높고 새로운 가치를 창출하기 위해(bouncing forward) 기능과 조직이 구성되어야 한다는 것이다.

이를 위해 미래 정부의 상(像)을 제시한 세계경제포럼(World Economic Forum, WEF)의 『The Future of Government: Lessons Learned from around the Worl $\mathrm{d}_{\Perp}(2012)$ 를 참조할 수 있다. WEF에 따르면, 4차 산업혁명 시기 정부는 “(1) 유연성 (flatter): 수평적 정책결정 구조를 통한 신속한 사회문제 해결이 가능한 정부, (2) 민첩성 /기민성(agile): 사회문제의 특성에 따라 자원, 조직, 프로세스 등 스스로 조직화할 수 있는 민첩한 정부, (3) 슬림화(streamlined): 기술의 발전 및 노동시장 재편을 통한 슬림 화된 정부, (4) 기술역량(tech-savvy): 미래지향적 기술에 능통한 정부”가 되어야 한

174) 양혜원·김면·차민경·김현경·노수경. 2020.「코로나 19가 문화예술분야에 미친 영향 및 정책대응방안 연 구」한국문화관광연구원, p.54. 
다. ${ }^{175)} \mathrm{WEF}$ 가 제시한 미래 정부, 즉 FAST 정부 중에서 에자일 정부는 복잡한 도전에 신속하게 대응하기 위해 공적·민간 자원을 동원하여 스스로를 조직화할 수 있으며, 문제 가 해결되거나 다른 조직이 그러한 도전을 대응하도록 준비가 되어 더는 필요가 없을 때, 스스로를 탈조직화(de-organize)할 수 있는 정부이다. 이러한 맥락에서 국제문화교 류 역시 민첩성·기민성을 기반으로 하여 회복탄력성을 제고할 수 있는 에자일 거버넌스 (agile governance)를 구축할 필요가 있다.

국제문화교류는 앞서 설명하였던 코로나19 시기 문화예술부문에서 드러난 취약성과 기회를 상당 부분 공유한다. 코로나19 팬데믹으로 인해서 국제문화교류 활동이 중단되 거나 연기되면서 관련 문화예술인의 피해가 발생할 뿐만 아니라 국제문화교류의 특성 상 활동 단절로 인한 새로운 관계 구축의 어려움 역시 존재한다. 회복탄력성 제고를 위 한 에자일 거버넌스는 변동성이 큰 상황에서 충격이나 위기가 발생할 가능성이 있거나 실제로 발생하였을 때, 무대응(non-response)이나 때늦은 대응의 비용이 잘 준비되지 못하지만 신속하게 대응하는 비용보다 훨씬 크다는 점에서 그 필요성이 높다. 기존의 조직으로서의 정부(government) 중심의 위기대응과 다른 점은 조직, 자원, 프로세스 등에 관한 표준운영절차(standard operation procedure, SOP)가 없거나 아주 유연하 다는 것이다. 즉, 예측하지 못한 위기에 대응하는 만큼 신속하고 새로운 실험과 이를 가 능하게 하도록 기존의 법·규제적 구조를 넘나드는 의사결정이 필요하다는 것이다.

국제문화교류의 회복탄력성을 위한 에자일 거버넌스를 위해서는 문제해결 능력을 갖 춘 기업가적 역량을 갖춘 공공 인적자원과 이들의 결정을 도와줄 실시간 정보와 현장 지식이 필요하다. 이를 위해서는 공공 인적자원에 대한 역량 강화가 필요하다. 여기에는 다양한 문제해결 능력에 대한 역량 강화, 대면-비대면 융합 프로그램에 대한 역량 강화 노력, 디지털/온라인 콘텐츠와 오프라인 콘텐츠의 융향에 대한 노력, 혁신기술을 활용한 문화예술콘텐츠 개발 등이 포함될 것이다.

\section{나. 공공-민간부문과의 파트너십 강화}

다양한 문제를 해결하는데 중요한 원칙 중 하나는 파트너십(partnership)의 강화이

175) 권기헌. 2018. "새로운 행정학의 개념탐색을 위한 전제: 좋은 거버넌스와 제4세대 정부모형의 구현 조 건.”「국정관리연구」, 13( 1), p.17. 
다. 사회문제가 복잡해지고 다양한 이해관계자가 연관되면서, 파트너십은 문제해결을 위 한 이행원칙으로 강조되고 있다. 예를 들면, UN SDGs 중 17번째 목표인 "Partnerships for the Goals"는 다른 16 개의 SDGs를 달성하기 위한 글로벌 파트너십의 활성화를 강 조한다. 또한, 최근 발표된 $\mathrm{OECD}$ 정책브리프, "Social Partnership in the Times of the COVID-19 Pandemic"(2020년 4월)에 따르면, 위기를 대응하는 방식이 공정하다 고 인식되고 이를 위한 노력이 모두에게 공유되었을 때 사회적으로 논쟁적일 수 있는 위기대응 방안은 효과적일 수 있는데, 사회적 대화와 파트너십은 구성원들이 유사한 행 동에 동의할 수 있도록 해줌으로써 일종의 조정 장치(coordination device)로서의 역 할을 수행한다. ${ }^{176)}$

이런 점에서 국제문화교류의 회복탄력성을 위해서는 다양한 문화적 이해당사자들 (cultural stakeholders) 사이의 파트너십, 협업이 중요하다. 파트너십을 통해서 정부와 공공부문은 국제문화교류의 세계적 현황과 관련 민간부문의 현실과 요구를 제대로 파악 할 수 있으며, 민간부문 역시 정부와 공공부문을 통해서 다양한 정보와 정책방향 등을 확인하고 리스크를 회피하기 보다는 감수할(risk-taking) 수 있다. 이러한 정보 공유를 통해 비용을 절감하고 투명성을 제고하며 새로운 가치를 창출할 가능성도 높아진다. 이 를 위해서는 정부-공공기관-민간부문 간 협의채널을 구축하고 제도화-활성화할 필요가 크다. 그리고 이러한 협의채널이 실제 사업과 연계될 수 있도록 해야 한다.

포스트-코로나19, 위드-코로나19 상황에서 파트너십은 더욱 중요해질 것이다. 여기에 서 강조하는 파트너십은 협소한 의미에서의 이해관계자(정부, 공공부문, 국제문화교류 관련 문화예술분야 종사자) 사이의 파트너십이 아니다. 미래의 파트너십은 현재의 이해관 계자를 포함하여 지방자치단체, 개인 창작자, 일반 시민(이주민 포함), 대상국의 중앙-지방 정부, 문화예술 관계자, 일반 시민 등 국제문화교류와 연계된 모든 이해관계자를 포함한다.

특히, 지방자치단체와의 파트너십은 매우 중요하다. 「국제문화교류 진흥법(약칭: 국제 문화교류법)」에 따르면, “국가와 지방자치단체는 국제문화교류 진흥을 위하여 종합적인 시책을 수립·시행하여야 하며,"(제3조 제1항) “특별시장·광역시장·특별자치시장·도지사. 특별자치도지사는 종합계획에 따라 매년 관할 지역의 국제문화교류 진흥 지역계획(이하 “지역계획”이라 한다)을 수립·시행하여야 한다"(제7조 제 1 항). 따라서, 현재 대부분의 지

176) OECD. 2020. "Social partnership in the times of the COVID-19 Pandemic", OECD Policy Responses to Coronavirus (COVID-19), OECD Publishing, Paris, p.5. 
방자지단체는 지역 상황에 맞는 '국제문화교류 진흥 지역계획'을 수립하여 시행하고 있다. 지방자치단체의 국제문화교류는 중앙정부 차원에서의 국제문화교류와 차별점이 존재한 다. 즉, 국가 간 경쟁이 심해지고, 자국중심주의가 강화될 것으로 예측되는 미래, 근 미래 (near future) 시점에서 중앙정부의 국제문화교류에 대해 상대국 혹은 경쟁국은 부정적 시각으로 비라볼 수 있다. 반면 지방자치단체의 국제문화교류는 상대적으로 정치적 뉘앙스 가 적으며, 보다 순수한 문화교류로 인식될 가능성이 높다는 점에서 회복탄력성과 지속가 능성을 제고할 수 있다. 이러한 점에서 지방자치단체의 국제문화교류(및 지방자치단체의 문화 $\mathrm{ODA})$ 와 연계를 강화하고 지방자치단체의 역량을 강화할 필요가 있다.

나아가 시민 참여(citizen engagement) 역시 중요하다. 국제문화교류의 회복탄력성 을 제고하기 위해서는 가장 기본적인 문화의 소비자이자 생산자인 시민의 역할에 대한 재고찰이 필요하다. 시민의 문화역량 강화를 위해 다양한 교육플랫폼평생교육, 대학 평 생교육원 등)을 활용하고, 이들이 국제문화교류에 직접 참여하여 경험을 할 수 있는 자 리를 마련해줄 필요가 있다. 마지막으로, 기업의 사회적 책임(corporate social responsibility, CSR) 관점에서 수행하는 사회공헌활동, ESG 경영과의 파트너십도 필 요하다. ${ }^{177)}$ 중장기적으로는 국제문화교류 관련 민관협력 투자펀드를 조성함으로써 다 양한 실험적인 사업을 수행하는 문화예술인이나 단체에 지원하고, 코로나19 상황과 유 사한 상황 발생 시 긴급지원을 위해서 활용할 수 있을 것이다.

\section{다. 한국국제문화교류 플랫폼 구축: K-Culture Portal}

변동성, 불확실성, 복잡성이 증대되는 미래 시점에서 지속가능하고 회복탄력성 높은 국제문화교류를 위한 근간에는 신뢰도 있는 데이터 생산, 축적, 관리, 활용이 필요하다. 코로나19 상황에서 문화예술분야 피해상황을 정확히 파악하고 이에 대한 정확한 정책대 응을 하기에는 관련 자료 구축이 매우 부족하였다.178) 에자일 거버넌스와 효과적인 파 트너십을 위해서 정확하고 다양한 통계자료는 필수적이다. 이는 투명성을 강화함으로써 다양한 이해관계자들의 정책 신뢰를 확보하고, 정책에 대한 순응도를 높일 수 있다는

177) “한국국제문화교류진흥원, CJ ENM과 비대면 해외사회공헌 진행," http://kofice.or.kr/g200_online/ g200_online_01_view.asp?seq=19283\&page=1\&tb|ID=gongji\&bunho=0\&find=\&search=

178) 양혜원·김면·차민경·김현경·노수경. 2020. 코로나 19가 문화예술분야에 미친 영향 및 정책대응방안 연 구」 한국문화관광연구원, p.235. 
점에서도 중요하다. 게다가, 이러한 자료 구축이 단순한 자료 모음이 아니라 장기적으로 빅데이터를 기반으로 한 예측시스템을 통해서 다양한 도전들을 사전에 예상하고 대응할 수 있는 기반 구축이 필요하다. 나아가 축적된 데이터를 활용한 근거기반(evidencebased) 정책형성에도 기여할 것이다.

현재 한국의 문화와 관련된 다양한 정보와 웹사이트가 존재한다. 하지만, 국제문화교 류의 서비스 공급자와 소비자를 연결해주고 관련된 정보를 한 곳에서 확인할 수 있는 통합적 플랫폼을 찾기는 어렵다. 국제문화교류 종합정보시스템('문화로')가 있지만, 이는 국제문화교류의 사업 정보를 제공하고 수집하는 역할에 그쳐, 한국의 문화, 한국과의 국 제문화교류에 관심이 있는 외국 정부, 공공기관, 민간단체, 일반 시민의 접근성과 활용 도가 매우 떨어진다. 전문가 설문조사에 따르면, '문화로'를 통해서 획득한 정보가 실질 적으로 도움이 되었다는 응답에 비해 그렇지 않다는 응답이 다소 높은 것으로 나타났으 며, '문화로'가 한국 국제문화교류 종합플랫폼으로 기능이 강화되어야 한다는 의견이 주 를 이루었다. 따라서, 다양한 이해당사자의 필요와 관심이 반영되고 실제로 활용도를 제 고할 수 있도록 '문화로'를 개선하거나 한국 문화 전반을 포괄하는 새로운 한국문화 포 털 구축이 필요하다.

\section{3. 국제문화교류 관리체계 기반 구축}

\section{가. 국제문화교류 성과관리체계 구축}

국제문화교류의 중장기적 발전과 성장을 위해서는 이에 대한 성과관리(performance management)가 필요하다. 국제문화교류 역시 국민의 세금이 주요한 재원이며, 결국 납세자인 국민의 관점에서 유의미한 결과를 창출하였는가가 중요한 요소로 간주될 필요 가 있다. 국제문화교류의 규모가 증가하고, 특히 불확실성이 큰 정책환경에서 가시적인 성과가 보이지 않는다면 이에 대한 비판이 증가할 것으로 예상할 수 있으며, 성과관리는 책무성(accountability)를 제고하기 위한 노력과 직결된다.

「제1차 국제문화교류 진흥 종합계획(2018 2022) 개정판」에 따르면, 국제문화교류의 비전은 “세계와 공감하고 협력하여 모두가 행복한 국제문화교류”이며, 비전 달성을 위해 3 개의 정책목표/추진전략(A전략적·체계적 국제문화교류,

숙제문화교류의 '새로운 기 
준' 대응, $\boldsymbol{\Delta}$ 국제문화교류 생태계 조성)과 8개의 추진과제가 제시되었다. 하지만, 어떻게 국제문화교류의 성과를 측정하고 관리할 것인지에 대해서는 제시된 바가 미흡하다. 즉, 결과에 기반을 둔 성과관리를 위한 노력이 수행되어야 한다. 물론 국제문화교류의 특성 상, 그 효과를 측정하고 지표를 설정하여 관리하기에는 어려움이 있다. 이러한 어려움에 도 불구하고, 성과관리를 위해서는 객관적이고 비교가능하며 신뢰할 수 있는 지표를 설 정하고, 그 성과를 추적, 모니터링해야 한다.

국제문화교류와 관련된 가장 포괄적인 지표는 『국제문화교류 지표개발 기초연구』에 서 제시되고 있다.179) 이 연구에 따르면, 국제문화교류 지표란 “국제문화교류 사업을 영위하는 기관들의 사업현황과 성과를 파악하기 위해 교류영역, 교류분야, 교류방법 등 의 활동기준을 적용한 측정도구이며, 궁극적으로 국제문화교류 활성화를 위한 정책지원 방향 수립의 방향성을 정립하기 위한 것”이다. 하지만, 김혜인 외(2017)에서 제시된 평 가는 활동기관별 현황을 파악하고 기초적인 평가를 위해서는 중요한 시도임에는 분명하 나, 국제문화교류의 전체적인 성과나 사업별 성과를 측정할 수 없다는 단점이 있다.

이러한 점에서 유사한 사례·연구를 기반으로 국제문화교류 성과를 측정하기 위한 지 표를 개발하고, 성과를 측정하며 정책 환류 노력을 전개해야 한다. 예를 들면, 우리나라 재정성과관리제도 내 “재정사업 자율평가제도," “국제개발협력 사업시행기관 자체평가” 등을 고려한다면, 국제문화교류 사업의 평가기준으로 적절성(relevance), 효율성 (efficiency), 효과성(effectiveness), 영향력(impact), 지속가능성(sustainability), 일 관성(coherence) 등을 제시하고, 이를 국제문화교류(사업)의 시간적 순서에 따라 "계획 (plan) $\rightarrow$ 투입(input) $\rightarrow$ 활동(activity)·과정(process) $\rightarrow$ 산출(output) $\rightarrow$ 결과 (outcome)·영향(impact)” 등 각각의 단계별 성과지표를 개발할 필요가 있다. 특히, 성 과관리의 중요성을 고려하여, $\boldsymbol{\Delta}$ 개별 국제문화교류 사업의 고유한 목적을 명확히 정의하 는지, $\boldsymbol{\Delta}$ 그러한 목적의 달성 여부를 무엇으로 평가할 것인지에 대하여 계량화된 지표 개 발 통해 자체적으로 측정하려는 노력이 있는지, $\boldsymbol{\Delta}$ 해당 기준에 의거하여 지속적으로 성 과를 추적하는지 등 성과관리 내용이 사업 계획 단계에서부터 고려될 필요가 있다.

더욱 중요한 점은 국제문화교류의 성과는 결국 교류의 대상이 되는 해외 문화예술관 련 기관, 현지 주민 등이 체감하는 효용성과 우리나라 문화에 대한 호감도 등으로 연결

179) 김혜인·최보연·송철재·이세정. 2017. "국제문화교류 지표개발 기초연구" 문화체육관광부. 
되는 것이다. 따라서 국제문화교류의 정책 대상자인 국내 시행기관, 해외 기관, 외국인 등에 대한 성과지표 개발과 관리가 필요하다. 또한, 이러한 성과관리제도가 실질적인 효 과를 거두기 위해서는 정책 환류체계가 갖춰져야 한다.

\section{나. 위험관리(risk management)}

코로나19, 포스트-코로나19 시대 국제문화교류와 관련된 다양한 리스크를 식별하고, 이에 대한 대응, 관리체계를 고려할 필요가 있다. 많은 국제문화교류 사업이 온라인으로 진행되거나, 온-오프라인 혼합으로 진행될 가능성이 있다. 이러한 점에서 다양한 정보, 때로는 민감한 정보(개인정보 등) 누출 등 사이버안보 측면에서 리스크 관리가 필요하다. 또한, 국가 간 경쟁과 갈등이 커지는 상황에서 국제문화교류 과정에서 발생할 수 있는 우리나라 문화에 대한 오해, 잘못된 해석, 악의적인 비난과 이의 지속적인 재생산 등에 대하여 즉각적으로 대응하고, 부정적 영향력을 상쇄할 수 있는 방안이 선제적으로 고려 될 필요가 있다.

또한, 국제문화교류 시행 인력과 관련된 리스크 역시 관리될 필요가 있다. 국제문화교 류를 실행하는 인력에 대한 인권 교육, 성인지 교육, (성)폭력 예방 교육, 문화적 다양성 에 대한 교육 등이 수행되고 체계적으로 관리될 필요가 있다. 예를 들면, 수료제도, 인증 제도 등을 통해서 교육을 받은 인력과 체계적 시스템이 갖춰진 기관에게 국제문화교류 사업 참여를 우선적으로 허용하는 방안 등을 고려할 수 있다. 나아가, 국제문화교류 시 행 인력을 잠재적 위험으로부터 보호할 필요가 있다. 사업 수행 대상국에서 국제문화교 류를 시행하면서 발생할 수 있는 위기관리 체계가 필요하다. 마지막으로, 문화유산에 대 한 리스크 관리 역시 필요하다. 이렇듯 종합적인 리스크 관리를 통해서 국제문화교류의 효과성과 지속가능성을 제고할 수 있다.

\section{다. 국제문화교류와 연관된 다양한 민관프로그램의 통합적 관리}

국제문화교류와 유사한 정책, 사업, 프로그램이 우리나라 정부, 공공기관 및 민간부문 에 의해서 수행되고 있다. 정부와 공공기관의 경우, 앞서 설명한 (문화)ODA뿐만 아니라 (문화)공공외교, 국제기구 분담금이 국제문화교류와 밀접하게 연관되어 있다. 민간의 경 
우, 기업의 국제문화교류 관련 CSR, ESG 활동 및 사회공헌활동을 포함한 민간 문화교 류 등이 국제문화교류와 유사한 목적을 지향한다. 하지만, 현재 이렇게 다양한 정책, 사 업, 프로그램 등이 동시다발적으로 수행되고 있지만, 통합적으로 관리되지 못해 유사한 사업이 중복되어 예산의 효율적 사용을 저해할 수 있다. 보다 중요한 점은 통합적 관리 의 부재로 인해 서로 상이한 비전과 가치 등을 추구함으로써 일관된 메시지 전달이 어려 울 수 있다.

따라서, 국제문화교류도 정부의 정책이자 한국의 전반적 이미지에 영향을 미친다는 점에서 일관성(coherence)을 제고하기 위한 노력이 필요하다. 물론 문화의 특성 상 일 관되고 단일한 메시지를 발신하는 것이 오히려 국제문화교류의 취지에서 벗어나고 효과 적이지 않을 수도 있다. 하지만, 이러한 우려가 국제문화교류와 유사한 사업, 프로그램 에 대해서 일정 수준의 통합적 관리가 불필요하다는 것을 의미하지는 않는다. 이러한 점을 고려하여 (포스트)코로나19 시기 국제문화교류와 관련된 다양한 사업, 프로그램에 대한 통합적 관리의 기반(민관 협의체 등)을 구축할 필요가 있다.

[그림 5-2] 국제문화교류 및 이와 관련된 정부·민간 프로그램의 연계성

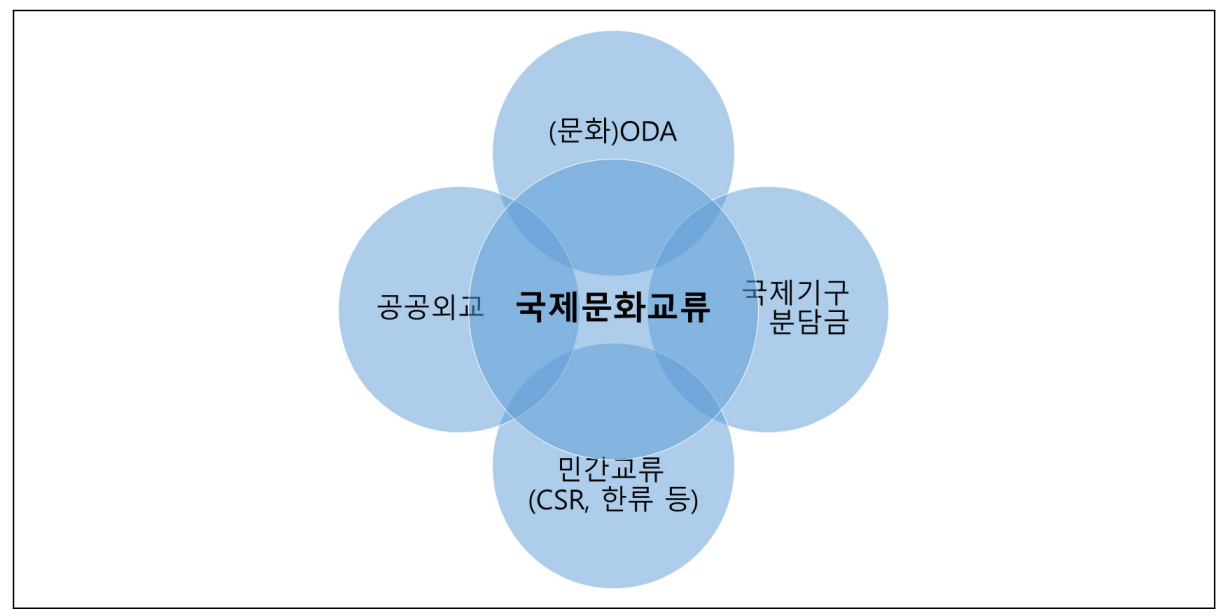

출처: 저자

구체적으로 정부와 민간 부문에서 시행되는 다양한 정책, 사업, 프로그램을 살펴보면 다음과 같다. 첫째, 국제문화교류는 공공외교와 매우 밀접하게 연관되어 있다. 「제1차 대한민국 공공외교 기본계획(2017 2021)」에 따르면, 우리나라 공공외교의 비전은 “국 
민과 함께, 세계와 소통하는 매력 한국”이며, 이러한 비전을 달성하기 위해서 문화공공 외교는 매우 중요한 역할을 수행한다.

\section{〈표 5-6〉 문화공공외교의 추진전략}

\begin{tabular}{|c|c|}
\hline \multicolumn{2}{|l|}{ 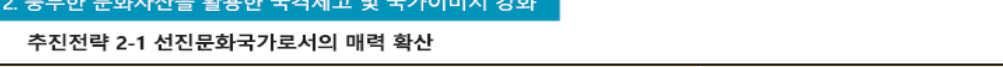 } \\
\hline 중점추진과제 & 소관부처(기관) \\
\hline 2-1-11 수교기념 및 주요외교계기 행사의 전략적 활용 & 외교부, 문체부, 교육부, 지자체 \\
\hline 2-1-2] 재외공관별 현지 맞춤형 한국 알리기 & 과기부, 외교부, 문체부, 산업부, 농식풍부, 지자처 \\
\hline 2-1-[3] 한국 예술품 및 미래형 문화 콘텐츠 소개공간으로서 재외공관과 문화원 활용 & 외교부, 문체부 \\
\hline \multicolumn{2}{|l|}{ 추진전략 2-2 풍부한 문화자산을 활용한 호감도 증진 } \\
\hline 중점추진과제 & 소관부처(기관) \\
\hline 2-2-11 한류(대중문화)의 전략적 확산 & 외교부, 문체부 \\
\hline 2-2-2] 전통·현대 한국 문화의 체계적 전파 & 문체부, 외교부 \\
\hline 2-2-3 국제 스포츠 행사의 효과적 활용 & 문체부, 외교부 \\
\hline 2-2-4 미래형 문화 콘텐츠 발굴 및 확산 지원 & 문체부 \\
\hline 2-2-[5] 한식 홍보 강화 & 농식품부، 외교부, 문체부 \\
\hline 2-2-6 한국 관광 인지도 선호도 제고 & 문체부, 외교부 \\
\hline \multicolumn{2}{|l|}{ 추진전략 2-3 쌍방향 문화 교류를 통한 소통 강화 } \\
\hline 중점추진과제 & 소관부처(기관) \\
\hline 2-3-11 쌍방향 문화교류 활성화 & 외교부, 문체부, 지자체 \\
\hline 2-3-2] 문화 네트워크 구축 & 외교부, 문체부, 지자체 \\
\hline 2-3-3] 문화예술을 활용한 글로벌 공헌 & 외교부, 문체부, 지자체 \\
\hline \multicolumn{2}{|l|}{ 3. 한국에 대한 올바른 인식과 이해 확산 } \\
\hline \multicolumn{2}{|l|}{ 추진전략 3-1 한국의 역사, 전통, 발전상 등에 대한 이해 제고 } \\
\hline 중점추진과제 & 소관부처(기관) \\
\hline 3-1-1 해외 한국 관련 오류 시정 및 기술 확대 & 외교부, 교육부, 문체부, 해수부 \\
\hline 3-1-2] 해외에서 한국을 접할 수 있는 공간 마련 & 외교부, 교육부, 문체부 \\
\hline 3-1-3 한국 홍보 콘텐츠 개발 및 공유 & 외교부, 문체부, 여가부 \\
\hline 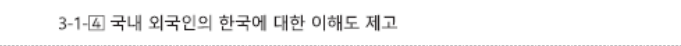 & 법무부, 지자체 \\
\hline 3-1-[5] 외국인 참여형 한국 관련 경연대회 개최 & 외교부, 문체부 \\
\hline 3-1-6 교육협려 활성화를 통한 차세대 네트워크 강화 & 외교부, 교육부, 여가부 \\
\hline 3-1-77 친한인사 기반 강화 & 외교부, 국가보훈처 \\
\hline \multicolumn{2}{|l|}{ 추진전략 3-2 한국학 진흥 및 한국어 보급 확대 } \\
\hline 중점추진과제 & 소관부처(기관) \\
\hline 3-2-11 해외 한국학 맞춤형 지원 강화 & 외교부, 교육부, 문체부 \\
\hline 3-2-2 차세대 한국학 전문가 육성 & 외교부, 교육부 \\
\hline 3-2-3 해외 한국어 교육 진흥을 위한 지원 강화 & 외교부, 교육부, 문체부 \\
\hline 3-2-4 해외 한국학 및 한국어 교육 진흥 유관기관간 협력 강화 & 외교부, 교육부, 문체부 \\
\hline
\end{tabular}

출처: 외교부. 2017, 「제1차 대한민국 공공외교 기본계획(2017 2021)」p. 53 54. 
문화공공외교의 추진전략에는 $\boldsymbol{\Delta}$ 선진문화국가로서의 매력 확산, $\boldsymbol{\Delta}$ 풍부한 문화자산을 활용한 호감도 증진, $\boldsymbol{\Delta}$ 쌍방향 문화 교류를 통한 소통 강화 등이 포함된다. 특히, 「공공 외교 기본계획」에서 제시하는 6 개 추진과제 중 2 개 추진과제, "추진과제2: 풍부한 문화 자산을 활용한 국격제고 및 국가이미지 강화”와 “추진과제3: 한국에 대한 올바른 인식과 이해 확산”과 15 개 추진전략 중 5 개 추진전략은 국제문화교류와 매우 밀접한 관계를 갖 는다(〈표 5-6〉 참조).

〈표 5-7〉 기관별 공공외교 사업규모 및 예산

\section{참고 기관별 사업규모 및 예산}

[중앙행정기관]

\begin{tabular}{|c|c|c|c|c|}
\hline \multicolumn{2}{|r|}{ 기관명 } & '21년 사업수 & '21년 예산 (백만원) & '20년 예산 (백만원) \\
\hline 1 & 육 & 12 & 41,412 & 74,192 \\
\hline 2 & 과학기술정보통신부 & 2 & 170 & 160 \\
\hline 3 & 교 부 & 64 & 34,946 & 28,662 \\
\hline $3-1$ & 한국국 제교류 재 단 & 37 & 46,562 & 39,806 \\
\hline 4 & 일 & 3 & 1,081 & 1,611 \\
\hline 5 & 법 무 & 3 & $14,087.78$ & 13,925 \\
\hline 6 & 방 & 11 & $8,368.9$ & 7,573 \\
\hline 7 & 행 정 안 전 부 & 2 & 45 & 60 \\
\hline 8 & 문 화 체 육 관 광 부 & 22 & 105,029 & 93,016 \\
\hline 9 & 농 림 축 산 식 품 부 & 5 & 3,739 & 4,259 \\
\hline 10 & 보 건 복 지 부 & 9 & 8,737 & - \\
\hline 11 & 경 & 1 & 1,600 & 1,500 \\
\hline 12 & 고 용 노 동 부 & 1 & 1,551 & 2,210 \\
\hline 13 & 여 성 가 족 부 & 13 & 3,688 & 5,813 \\
\hline 14 & 국 토 교 통 부 & 4 & 2,340 & 2,534 \\
\hline 15 & 해 양 수 산 부 & 1 & 100 & 100 \\
\hline 16 & 국 가 보 훈 처 & 3 & 4,038 & 5,303 \\
\hline 17 & $\begin{array}{lll}\text { 법 제 } & \text { 처 }\end{array}$ & 2 & 312 & 315 \\
\hline
\end{tabular}

출처: 외교부. 2021. 「2021년도 공공외교 종합시행계획 |권」, p. 6.

「2021년도 공공외교 종합시행계획 I권」에 따르면, 2021년 문화체육관광부는 「공공 외교 기본계획」 중 18 개의 중점추진과제에서 총 22 개의 사업을 시행하며, 예산(안)은 1050.29억 원에 달한다. 이는 외교부(한국국제교류재단 포함)를 포함한 전체 중앙행정 기관 중 가장 많은 규모이다. 실제로 문화체육관광부는 공공외교 활동 추진과 국제문화 교류를 연계하여 정책을 수립, 집행하고 있다. 예를 들면, 공공외교 활동 추진을 위한

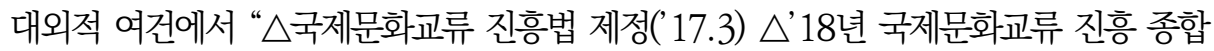
계획 수립('18.5) 및 $\triangle$ 국제문화교류 전담기관 설립('18.2) 등 국제문화교류의 법적·행 정적 조건 마련"을 주되게 언급하였다(외교부 2021, 349). 특히 문화체육관광부-외교부 
간 국장급 회의의 정례적 개최를 진행하는 등 국제문화교류와 (문화)공공외교 간 시너지 를 창출하기 위한 노력이 필요하다.

둘째, 국제기구 분담금 역시 국제문화교류와 연관성이 있다. 문화체육관광부는 2019 년 2,275백만 원, 2020년 1,898백만 원, 2021년 2,504백만 원을 국제기구 분담금으로 편성하였다(외교부 2020). 구체적으로 살펴보면, 문화체육관광부는 유네스코, 유엔세계 관광기구, 세계지식재산기구, 세계반도핑기구 등에 분담금을 납부하고 있는데, 이 중 의 무적으로 납부해야하는 분담금(의무분담금)뿐만 아니라 재량분담금도 납부하고 있다는 점에서 국제문화교류와도 연계되어 있다.

마지막으로, 민간부문에서의 문화교류 사업이다. 코로나19 위기 상황에서 많은 기업 들은 비록 영업이익이 줄어들었지만, 사회공헌활동은 늘리고 있다. ${ }^{180)}$ 특히 ESG 경영 이 기업의 지속가능한 성장을 위해서 매우 중요해지면서 기업들의 사회적 기여, 사회적 가치 창출 활동은 더욱 커질 것으로 전망된다. 또한, 이는 우리나라 기업, 특히 문화 관 련 기업들의 국제문화교류 사업 수행에도 영향을 미칠 것으로 예상된다. 예를 들면, 한 류와 관련되어 한식 관련된 기업의 경우, 해당 국가에 대한 ESG 경영 차원에서 한국 음식문화에 대한 이해를 높이는 사회공헌활동을 수행함으로써 기업의 이미지뿐만 아니 라 우리나라의 문화에 대한 이해를 제고할 수 있다. 민간부문에서의 다양한 국제문화교 류 사업에 대한 파악과 협업이 필요하다. 이러한 맥락에서 한국국제문화교류진흥원은 “민관협력 해외사회공헌 사업”을 수행하고 있다. 국제문화교류와 연관된 이러한 다양한 정책, 사업, 프로그램을 통합적으로 관리하기 위한 노력이 필요하다.

\section{4. 온라인 오프라인 융합 프로그램}

\section{가. 온라인 국제문화교류 인프라 지원}

코로나19 팬데믹 발생 이후 국제문화교류와 관련된 가장 큰 변화 중 하나는 본격적으 로 온라인을 활용하기 시작하였다는 점이다. 코로나19 팬데믹이 문화예술분야에 미친

180) 조선일보. 2021. 5. 31. "기업들의 “따뜻한 손길' 코로나에도 더 늘었다.” 출처: https://mww.chosu n.com/economy/industry-company/2021/05/31/2XCN5DFGCRDC7C2ZLJANORPDEE/; 뉴 스핌. 2021. 02. 21. “코로나19 위기에 $\cdots$ 기업들, 영업이익 줄어도 사회공헌 늘렸다." https://mww. newspim.com/news/view/20210221000067 
부정적 영향은 매우 지대하다. 많은 국내외 문화 행사, 예술 공연, 전시 등이 취소·연기 되었다. 그로 인해, 문화예술분야 종사자들의 소득은 감소하고 고용안정성은 악화되었 다. 구체적으로 우리나라에서 2020년 1월부터 8월까지 취소된 공연건수는 9,687건, 매 출 피해는 총 1,967 억 원(건당 매출액 합산)에 이르는 것으로 나타났다.181) 한국 공연예 술통합전산망에 따르면 2020년 8월부터 12 월까지 공연건수와 개막편수는 지난해 같은 기간 대비 약 $43 \%$ 줄어들었으며, 매출액은 전년 같은 기간 대비 약 $67 \%$ 감소한 587 억 원에 머무르는 등 큰 타격을 입은 것으로 집계되었다. 특히 한해 공연시장 매출액은 견 인하는 연말연시 공연이 대폭 취소된 12월 공연시장 매출액은 전년 대비 약 $91 \%$ 줄어든 것으로 나타났다. 182 )

이러한 위기상황을 극복하고 새로운 기회를 창출하기 위해 많은 문화예술분야 종사자들 과 기업, 조직들은 비대면 온라인 방식으로의 전환을 도모하고 있다. 예를 들면, 실연을 펼칠 수 있는 극장 등 오프라인 플랫폼이 봉쇄됨에 따라 많은 공연예술인과 제작·기획사가 유튜브와 네이버 등 온라인 플랫폼을 통해 공연실황을 선보이기 시작했다. 네이버에 따르 면, 2019년 월평균 7 8건에 그치던 공연영상은 코로나19가 악화된 2020년 2월부터 지난해 대비 큰 폭으로 증가해 월평균 50 60건에 달하는 것으로 집계되었다. 특히 국립극 장, 예술의 전당, 세종문화회관, 서울예술단, 국립극단, 국립국악원 등 공공의 지원을 받는 공연장과 예술단체들이 그동안 아카이브용 제작, 소장 중이던 자체 공연의 영상을 유튜브 와 네이버tv 등을 통해 무료로 소개하는 등 공연영상 유통에 공공기관이 앞장섰다.183)

〈표 5-8〉2020년 한국 공연 스트리밍 현황

\begin{tabular}{c|c|c|c}
\hline 기관 & 주요 영상화 작품 & 스트리밍 채널과 방법 & 스트리밍 시기 \\
\hline 국립극장 & 뮤지컬 '불꽃놀이' & $\begin{array}{c}\text { 국립극장 자체 누리집 } \\
\text { 유료중계 }\end{array}$ & $2020.09 .25 ~ 26$. \\
국립오페라단 & $\begin{array}{c}\text { 서귀포예술의전당 } \\
\text { 기획공연 } \\
\text {-오페라 '사랑의 묘약' }\end{array}$ & $\begin{array}{c}\text { 서귀포시 유튜브/ } \\
\text { 페이스북 무료 실황중계 }\end{array}$ & 2020.11 .26$. \\
\hline
\end{tabular}

181) 뉴데일리. 2020.10.7. “코로나 폭탄’에 매출 급감.. 공연·미술계 2646억 피해.” 출처: http://www.newdaily.co.kr/site/data/html/2020/10/07/2020100700219.html. 검색일 - 2021.05.19.

182) 예술경영지원센터. 2020.12. “새로운 유통질서 : 공연 스트리밍 플랫폼의 현황" 2020 공연시장 이슈리 포트 2호, p.4.

183) 예술경영지원센터. 2020.12. “새로운 유통질서 : 공연 스트리밍 플랫폼의 현황" 2020 공연시장 이슈리 포트 2호, p.5. 


\begin{tabular}{|c|c|c|c|}
\hline 기관 & 주요 영상화 작품 & 스트리밍 채널과 방법 & 스트리밍 시기 \\
\hline & $\begin{array}{l}\text { 창작 오페라 } \\
\text { '레드 슈즈' }\end{array}$ & $\begin{array}{c}\text { 네이버TV와 VLIVE } \\
\text { 무료 생중계 }\end{array}$ & 2020.09 .05 \\
\hline & $\begin{array}{l}\text { 콘서트오페라 } \\
\text { '피델리오' }\end{array}$ & 네이버TV 무료 생중계 & 2020.10.23. \\
\hline 국립합창단 & $\begin{array}{l}\text { 미디어 콘서트 } \\
\text { 'Poetic Colors' }\end{array}$ & 네이버TV 후원 라이브 & 2020.12.19. \\
\hline 국립현대무용단 & 댄스 필름 ‘볼레로 만들기’ & $\begin{array}{c}\text { 네이버TV와 유튜브 } \\
\text { 무료 생중계 }\end{array}$ & 2020.11.16 19. \\
\hline 경기시나위 오케스트라 & 메타퍼포먼스 :미래극장 & 트위치 무료 생중계 & $2020.11 .6 \sim 7$. \\
\hline 서울예술단 & $\begin{array}{c}\text { 창작 가무극 } \\
\text { ‘잃어버린 얼굴 1895' }\end{array}$ & 네이버TV 후원 라이브 & 2020.09.28 29. \\
\hline 한국문화예술교육진흥원 & $\begin{array}{l}\text { 꿈의 오케스트라 } \\
\text { 10주년 기념공연 }\end{array}$ & 유튜브 실황중계 & 2020.11.17. \\
\hline
\end{tabular}

이러한 문화의 디지털화 현상은 코로나19 팬데믹 이후 가속화되고 보편화되고 있다. 2020년 11월 미국에서 진행된 설문조사에서 $72 \%$ 의 미국인들은 예술공연 관람을 온라 인 방식으로 전환을 계획하고 있다고 응답하였다. 그리고 많은 오케스트라, 밴드, 뮤지 션들이 줌, 페이스북, 인스타그램 등 웹베이스 프로그램을 사용하여 라이브 콘서트를 진 행하였다. 많은 아티스트들이 여러 가지 버츄어 플랫폼을 활용하여 자신들의 콘서트를 진행하였거나 준비 중이다. ${ }^{184)}$ 공연스트리밍 플랫폼을 통해 소개되는 공연의 영상화는 전세계적인 현상으로 2020년 11월 ‘트랜드마켓리서치’에서 발간한 시장조사 리포트에 따르면, 2017년 320억 달러에 불과하던 전세계 공연실황중계 시장 규모는 2026년까지 600억 달러로 성장할 것이라고 전망되고 있다. 185$)$ 이렇듯 코로나19 이후 문화예술 분 야의 활동에 있어서 온라인방식을 활용한 공연과 문화행사는 향후 더욱 보편적인 활동 이 될 가능성이 크다.

하지만, 개별 문화단체나 공연밴드 등은 온라인 공연 방식을 활용하는데 있어서 여러 가지 어려움이 있다. 많은 아티스트들과 예술 조직들은 새로운 장비와 시스템을 구입해 야 했고, 소리와 시각 편집 등 새로운 기술을 익혀야 했다. 아트펀드라는 워싱턴의 비영 리 기구는 2020년 12월 47개의 공연 그룹들을 대상으로 설문조사를 실시하였는데, $100 \%$ 온라인 프로그램을 활용하고 있다는 것을 확인하였다. 그리고 기술적인 부분과

184) Guiber, Greg and Lain Hyde. 2021. "Covid-19 Weekly Outlook." COVID-19 RSFLG Data and Assessment Working Group. p.6.

185) https://www.trendsmarketresearch.com/report/analysis/MMR/global-live-streaming-market 
장비 장만 등에서 많은 어려움을 겪고 있음을 확인하였다. ${ }^{186)}$

〈표 5-9〉 미 아트펀드 서베이 결과

\begin{tabular}{c|c}
\hline \multicolumn{2}{|c}{ 질문 : 디지털 프로그래밍으로 전환에서 가장 어려운 점 } \\
\hline 기술적 요구에 대한 청중들의 접근 & $54(\%)$ \\
\hline 장비 & 54 \\
\hline 기술능력 & 50 \\
\hline 수용성 & 48 \\
\hline 아티스트와 스텝들의 기술장비 접근성 & 46 \\
\hline 지불모델 & 37 \\
\hline 소프트웨어 & 28 \\
\hline 기타 & 35 \\
\hline
\end{tabular}

우리나라의 상황 역시 다르지 않다. 2020년 9월 10월 문화예술분야 종사자 $(1,223$ 명)를 대상으로 진행된 설문조사에 따르면, 약 $40.7 \%$ 의 응답자가 온라인·비대면 콘텐츠 (온라인 포럼, 세미나 참여 제외)에 참여한 것으로 답하였다. 참여하지 않은 이유로는 비용이 없거나(30.3\%), 시설·장비가 없거나(28.7\%), 방법을 몰라서(24.8\%), 기술을 몰 라서(22.7\%) 등 비용과 역량과 관련되어 온라인·비대면 콘텐츠를 활용하지 못하였다는 응답이 많았다. 특히 온라인·비대면 콘텐츠 관련 애로사항의 경우, 이러한 비용과 장비, 인력 등 인프라와 관련된 애로사항이 두드러진 것으로 나타났다.187)

이러한 문제점은 국제문화교류에서도 동일할 것으로 쉽게 추정할 수 있다. 따라서, 국 제문화교류의 디지털 전환을 위한 인프라 구축과 역량 강화 등 전략적 지원이 매우 중요 하다. 국제문화교류와 관련된 콘텐츠 제작을 위한 비용, 시설, 공간, 장비 지원뿐만 아니 라 인력 지원, 역량 강화(교육, 홍보, 유통 등) 등 전반적이면서도 세부 분야별 맞춤형 지원이 필요하다. 전문가 설문조사 결과를 통해서 이러한 정책적·전략적 필요성을 확인 할 수 있는데, 특히 온라인/비대면 콘텐츠 활성화를 위해서는 플랫폼 구축 및 유통 활성 화 지원, 제작비용 지원, 공간·시설·장비·교육 지원 등이 강조되었다.

186) Guiber, Greg and Lain Hyde. 2021. "Covid-19 Weekly Outlook." COVID-19 RSFLG Data and Assessment Working Group. pp.7 8.

187) 양혜원·김면·차민경·김현경·노수경. 2020. 「코로나 19가 문화예술분야에 미친 영향 및 정책대응방안 연 구」한국문화관광연구원, pp.277 278. 
동시에 제작 관련 지원뿐만 아니라 교류대상국의 온라인 국제문화교류와 관련된 준비 도, 수용성에 대한 조사도 필요하다. 즉, 지역별, 국가별, 세대별로 서로 상이한 온라인 플랫폼을 활용할 가능성이 높다는 점에서 현지 맞춤형 콘텐츠 제작 지원이 필요하다. 나아가, 현지에서 온라인 국제문화교류가 잘 수행되기 위해서 인프라 구조가 필요하다면 (문화)ODA 및 기업의 CSR, ESG 활동과 연계한 사업을 추진할 필요가 있다.

\section{나. 한국문화체험 Kit: 내국인-국내 거주 외국인-해외 현지인 연계 체험}

코로나19 펜데믹으로 인해 국제문화교류를 새로운 방식으로 수행할 필요가 증대하였 다. 코로나19 종식으로 사회적 거리두기가 사라진다고 하더라도 비대면 온라인을 활용 한 국제문화교류는 여전히 중요할 것이다. 그럼에도 불구하고 비대면 온라인으로는 충족 되지 못하는 문화적 수요가 분명히 존재한다. 즉 문화콘텐츠가 갖는 경험적 특성을 고려 하여, 비대면 온라인 방식과 실제 체험을 동시에 수행할 수 있는 방안을 고려할 수 있다.

이를 위해서 우리나라의 다양한 문화를 체험할 수 있는 kit을 제작하여, 우리나라 시 민, 국내 거주 외국인, 해외 교민, 해외 현지 주민 등 관심이 있는 다양한 개인들이 온라 인으로 참여하는 방식이다. 이러한 문화체험 kit는 공예, 서예, 도자기, 한국화 등 전통 문화를 체험할 수 있는 도구뿐만 아니라 박물관, 미술관 큐레이터와 함께하는 체험(3D 종이모형 등), $\mathrm{k}$-pop 댄스, $\mathrm{k}$-drama 주인공 체험, 한국 전통음식 만들기(1인용 김장김 치 키트) 등 다양한 $\mathrm{kit}$ 가 포함된다.

여기에서 중요한 점은 국내 거주하는 외국인이 문화예술분야 종사자와 함께 체험하고 이를 실시간으로 해외 현지 주민들과 소통함으로써 실제로 체험하는 경험(문화 체험과 더불어 우리나라 일반시민과의 교류 경험)을 갖도록 해준다는 점이다. 즉, 현재의 다양 한 문화체험키트가 일방향적이고, 개인적 경험에 머무른다는 한계가 있다는 점에서 이를 실시간 비대면 방식으로 극복하되 쌍방향적 소통을 강조하는 것이다.

\section{다. 메타버스 구축을 통한 국제문화교류의 디지털 가상화, 일상화}

메타버스는 '가공.가상'이나 ‘초월’을 의미하는 메타(meta)와 '세계·우주'를 뜻하는 유니 버스(universe)를 합성한 말이다. 사용자들은 3차원 가상의 공간 안에서 아바타를 이용하여 많은 사람들과 소통을 하고 함께 친분을 쌓고, 학습이나 공동의 작업을 진행할 수 있다. 
코로나19 팬데믹과 디지털 기술의 발전이라는 맥락에서 이러한 메타버스의 활용도는 더욱 커질 것으로 예상된다. 우리나라 정부도 2021년 7월 발표한 「한국판 뉴딜 2.0」 정책에서 디지털 뉴딜의 핵심 추진과제로 “메타버스 등 초연결 신산업 육성”을 새롭게 추가하였다. 188) 여기에는 "개방형 메타버스 플랫폼 개발 및 데이터 구축, 관광 유니버스 등 다양한 메타버스 콘텐츠 제작 지원" 등이 포함된다. 189) 특히 원격교육, 방송.미디어, 관광.여행 등의 분야에서 국가차원의 지원이 예정되어 있다. 그리고 2022년 문화체육관 광부 예산에 메타버스 관련 예산이 포함되었다. $\boldsymbol{\Delta}$ 확장 가상 세계(메타버스) 콘텐츠 제작 지원 및 공적 기능 연계(204억 원, 신규), $\boldsymbol{\Delta}$ 케이(K)-확장 가상 세계(메타버스) 조성연구 (3억 원, 신규) 관련 예산이 반영되었고, 향후 지속적으로 관련 정책이 추진될 예정이다.

이러한 정부의 정책 방향에 맞추어 국제문화교류 역시 메타버스를 활용하여 포스트코로나19 시대를 준비할 필요가 있다. 특히, 국제문화교류의 중요한 축을 차지하는 공 연·전시 활동과 메타버스를 연계할 수 있다. 해외의 대표적 메타버스 플랫폼인 '포트나 이트(Fortnite)'에서는 지난 2020년 9월 방탄소년단의 “Dynamite” 안무 버전이 최초 로 공개되어 주목을 받았는데, 이용자의 아바타가 이러한 안무를 출 수 있을 뿐만 아니 라 여러 이용자가 모여 군무를 출 수도 있었다.190) 가상현실, 증강현실, 확장현실 등 실 감기술을 활용한 가상 박물관, 미술관 등은 이용자에게 실제와 비슷한 경험을 선사할 수 있을 뿐만 아니라 메타버스에서는 이용자들끼리의 상호작용을 가능하게 한다는 점에 서 국제문화교류의 목적에 부합하는 활동이 가능하다.

또한, 온라인 교육에서도 메타버스의 활용도가 높다. 코로나19 팬데믹은 기존에 시도 되었지만 빈번히 좌절되거나 한정적으로 활용되었던 온라인 비대면 학습 시스템이 본격 적으로 광범위하게 이용되도록 만들었다. 온라인 학습 시스템은 집, 카페 등 공간의 제 약과 시간적 제약을 받지 않고 학습을 할 수 있고, 코로나19의 위협에서 벗어나 자유롭 게 공부를 할 수 있다는 장점이 있다. 하지만, 온라인 학습 시스템이 가지는 한계도 분명 하다. 학습에 있어서 교수자와 학생 간, 학생 상호 간 소통 또한 매우 중요한 학습요소이 지만, 현재 대부분의 온라인 학습 시스템은 이러한 상호소통이 충분히 이뤄지기에는 한 계적이다. 특히 사전에 녹화된 영상일 경우 전혀 학습자와의 소통이 이루어질 수 없다.

188) 관계부처 합동. 2021. "한국판 뉴딜 2.0: 미래를 만드는 나라 대한민국"

189) 관계부처 합동. 2021. "한국판 뉴딜 2.0: 미래를 만드는 나라 대한민국" p.28.

190) http://www.aitimes.com/news/articleView.html?idxno=139816 
그리고 줌과 같은 시스템을 활용하여 실시간으로 수업이 진행되더라도, 강사는 자신의 얼굴과 강의자료를 보여주며 강의를 진행하고, 참여하는 학생들은 모두 카메라와 마이크 를 끈 채 수업을 듣기만 하는 경우가 대부분이다. 강의 하는 사람들은 학생들이 자신의 설명을 제대로 보도 듣고 하는지 확인할 수 없고, 확인하고자 하는 의지를 가지더라도 확인하기 어려운 상황이다.

메타버스 기술을 활용하여 온라인 학습 시스템을 보완하여 사용자들의 관심을 더 잘 유도하고 학습의욕을 고취할 수 있다. 온라인 수업이 잘 진행되려면, 강사들이 학생들의 얼굴을 보면서 실시간으로 강의할 수 있어야 하고, 수업시간에 학생들의 소그룹 활동이 가능해야하며, 학습 내용을 확인하기 위한 퀴즈도 동시에 자유롭게 시행될 수 있어야 한다. 강사가 일방적으로 혼자 설명하지 않고, 학생들의 의견도 자유롭게 들을 수 있고, 학생 상호간의 소통도 잘 이루어질 수 있도록 해야 한다. 특히 실시간 강의가 아니라면, 학생간의 소통이 수업시간에 제대로 이루어 질 수 없기 때문에, 이러닝 시스템 내에서 학생 간의 소통과 소모임 활동 등이 가능한 공간을 구현하여 이를 학생들이 자유롭게 활용할 수 있도록 해야 한다. 이러한 메타버스 기술을 활용하여 가상 공간을 만들어낸다 면, 온라인 이러닝 시스템의 활성화에도 큰 도움이 될 수 있다.

나아가 우리나라의 다양한 관광지와 현지 지역문화를 가상 공간에서 체험하고, 한류 스타와 전문 해설사가 함께 세계 각국에서 온라인으로 접속한 이용자에게 이러한 관광 지와 문화를 설명해 준다면, 시너지효과를 거둘 것으로 기대된다. 예를 들면, 메타버스 이용자들이 전주를 배경으로 한 메타버스에서 전통 한옥에 대한 설명을 듣고 마당에서 전통놀이인 윶놀이를 하는 등 다양한 체험을 하는 방식이 가능할 것이다. 이렇게 메타버 스를 활용한 국제문화교류는 문화교류의 시공간적 제약을 넘을 수 있으며, 쌍방향적 문 화적 체험의 일상화, 상설화를 통해서 새로운 가능성을 보여준다. 

코로나19 이후 국제문화교류 활성화방안 연구

제6장

결론 



\section{제1절 요약}

본 연구는 코로나19 팬데믹에 따른 국제문화교류의 현황과 변화된 환경을 파악하고, 국내 국제문화교류 현황과 인식을 파악하고, 해외 주요국가와 문화예술관련 국제기구의 관련 정책동향을 분석하여 코로나 시대의 변화에 대응하면서 한국의 국가이익에 부합하도 록 국제문화교류의 '새로운 기준'에 맞는 국제문화교류 활성화 정책방안을 도출하는 것을 목적으로 한다.

코로나 이후 디지털 기술을 기반으로 한 사회적 변화는 새로운 기회의 창출과 새로운 문화의 발전 가능성이 증대된다. 이러한 사회문화적 변화를 고려하여 국제문화교류 정책 의 재검토가 필요하다. 코로나 상황으로 인하여 그 활용도가 급격히 증가된 디지털 기술 의 활용도 고려한 국제문화교류 방안도 검토할 필요가 있다. 포스트 코로나 상황에서 국제문화교류 정책이 잘 이루어지기 위해서는 기존의 문제점을 고려한 개선책과 정책 전반에 대한 체계적 재정립이 필요하다. 이것이 국제문화교류의 새로운 기준에 부합하는 정책의 기본이다.

국제문화교류 관련 주요국의 동향은 다음과 같다. 미국은 2020년 주요 프로그램들은 중단되기도 하였다. 하지만, 2021년 1월 프로그램이 재개되어 진행되고 있고, 각 프로 그램 별로 코로나19 대응책과 정보업데이트를 꾸준히 하면서 국가별로 대응책을 마련하 여 교류 프로그램들을 진행하고 있다.

캐나다 예술위원회는 Arts Abroad 펀드를 운영하고 있다. 이 펀드는 캐나다 예술가 들의 국제적 활동을 지원하기 위하여 조성되었다. 코로나19로 인한 여러 여행제한 조치 와 행사 취소 등의 어려움 속에서도 캐나다 예술가들이 국제교류 활동을 지속하도록 지 원하고 있다.

EU는 Perform Europe 프로그램 시행하고 있다. EU 지역 여러 국가출신들이 모여 공동작업을 하도록 하고 이를 온라인과 여러 지역에서 전시될 수 있도록 한다. 크리에이 티브 유럽(Creative Europe) 프로그램에 따라 혁신적이고 포괄적이며 지속 가능한 유 
통 및 공연 예술 분야의 투어 모델을 지원하기 위한 새로운 도구로서 “퍼폼 유럽 (Perform Europe)"이 기획되었다.

영국은 다양한 프로그램을 진행하고 있다. 영국관광청이 주관하는 관광교역전인 트래 블마트(ExploreGB)가 온라인으로 진행되었다. 영국문화원은 코로나 19 시대에 전 세계 사람들이 교육에 접근할 수 있고 교류가 가능하도록 단체, 기관, 자금지원부처와 협력하 여 온라인을 통해 Newton Fund 정보 및 많은 활동을 전달하고자 하고 있다. 영국 문화 원은 코로나 19 상황에서 문화 교류를 지속하기 위해 다양한 온라인 행사를 마련하였다. 프랑스 문화원(Institut français)은 18-25세 청년층의 프랑스어 학습을 장려하기 위 해 \#plusloin 이라는 디지털 캠페인을 시작하였다. 이 캠페인은 웹 사이트, SNS, WhatsApp에서 액세스할 수 있는 전화번호로 이용할 수 있으며, 이로 인해 전 세계 젊 은이들이 프랑스어로 대화할 수 있게 하였다. 프랑스 문화원은 25년 이상 프랑스와 전 세계의 예술가 거주지를 개발하고 지원하는 프로그램을 운영해왔다. 코로나로 인하여 변 화된 상황에서 당초 2020년 3월에 개최 예정이었던 레지던시관련 컨퍼런스인 “Reflecting Residencies conference"를 2020년 10월 22일과 23일 간 개최하며 레 지던시 프로그램 관련 정책을 새롭게 구성하는 것에 대하여 모색을 하고 있다. 프랑스 문화원은 코로나 상황을 극복하기 위하여 해외 각 프랑스 문화원들이 개발한 이니셔티 브들을 공유할 수 있도록 네트워크를 구성하여 운영하고 있다.

독일 연방 외무부 및 괴테 연구소는 문화와 교육 기관을 위한 2020 국제 구호 기금을 운영한다. 이 기금은 파트너 국가의 기관을 지원함으로써 국제 문화 협력이 지속되도록 하기 위한 것이다. 이 이니셔티브는 COVID-19 전염병의 결과로 고통 받고 있고 다른 자금원에 접근할 수 없는 유럽 연합 이외의 국가에 기반을 둔 문화 기관을 위한 것이다.

이탈리아 문화부는 이탈리아 문화에 바용을 지불하고 접근할 수 있는 온라인 플랫폼 구축을 위하여 1000 만 유로의 예산을 배정하였다. 이 플랫폼은 일명 'Netflix of Italian culture' 로 불리었으며, 정식 명칭은 ITsART로 정해졌다. 이 플랫폼은 유료와 무료 콘텐츠를 모두 운영하며, 이 플랫폼을 통하여 이탈리아 음악, 오페라, 연극, 영화, 다양한 박물관 소장품 등에 대한 접근이 이탈리아 국내 뿐만 아니라, 해외에서도 가능하도록 하는 것이 목적이다.

일본국제교류기금(Japan Foundation)은 첫 번째, JF digital collection 웹페이지를 별도로 구성하여, 온라인 문화표현과 대화창구로 활용하고 있다. JF digital collection 은 국제교류기금 일본 본부와 전세계 사무소에서 진행하는 온라인 프로그램을 모두 보 
여주는 온라인 플랫폼이다. 두 번째, 일본어를 배우고자 하는 외국인을 대상으로 하는 일본어 교육프로그램에 이러닝 시스템을 적극 활용하고 있다. 일본은 일본어 교육 이러 닝(e-learning) 프로그램을 운영하고, 관련 정보를 확인할 수 있는 웹페이지(Minato)를 구성하여 운영하고 있다. 세 번째, 일본국제교류기금의 국제교류기금 아시아센터는 코로 나 대응을 위한 신규 프로그램으로 '아시아 시민교류 조성 프로그램'을 기획하였다. ASEAN 국가들이 중심이 되는 아시아와의 문화교류 사업을 기획·실시하는 일본 국내단 체를 대상으로 관련 경비를 지원하는 프로그램이다.

호주는 개별 예술가들과 문화단체들이 예술 프로젝트 카테고리의 지원 사업을 통해 국제문화교류 사업을 할 수 있도록 하고 있다. 물리적 이동이 어려운 상황에서, 디지털 기술과 비대면 방식을 활용한 국제문화교류 활동을 지속하는 것을 권장하고 있다.

전문가 설문조사결과는 다음과 같다. 우선, 한국 외교정책 수행에 있어 국제문화교류의 중요성에 대하여 물었다. 대다수의 응답자들은 한국이 외교정책을 수행하는 데에 있어 코로나 19 의 영향과 상관없이 국제문화교류의 중요성을 높게 평가하고 있는 것으로 나타 났다. 두 번째, 국제문화교류 사업에 대한 정부의 정책과 지원에 대한 만족 정도를 묻는 설문에 응답자들의 코로나19 팬데믹을 전후 인식의 차이를 확인하였다. 전체적으로 '보 통이다'라는 응답이 코로나 이전 $61 \%$, 코로나 이후 $55 \%$ 로 크게 국제문화교류에 대한 정부정책에 큰 선호인식이 없는 것으로 나타났다. 세 번째, 코로나 19 로 인한 정부의 국제 문화교류 사업 지원 필요성 인식 문항에서는 현재 시점까지 정부로부터 받은 지원들이 향후에도 더욱 필요하다고 인식하고 있다, 특히 유연한 예산 집행 지원과 행정 절차의 간소화에 대한 향후 필요성을 크게 느끼고 있었으며, 이에 대한 우선적인 지원을 고려해 야 할 것으로 보인다. 지원 유형별로 살펴보면, 유연한 예산 집행 지원은 현재 정부로부터 받은 지원에 대한 필요성 $73.0 \%$, 향후 필요성 $90.0 \%$ 로 $17.0 \%$ p 더 높았다. 행정 절차의 간소화는 현재 정부로부터 받은 지원에 대한 필요성 $72.0 \%$, 향후 필요성 $86.0 \%$ 로 $14.0 \% \mathrm{p}$ 더 높았다. 비대면 사업 진행을 위한 편의 제공은 현재 정부로부터 받은 지원에 대한 필요성 $67.0 \%$, 향후 필요성 $85.0 \%$ 로 $18.0 \%$ 더 높았다. 네 번째, 향후 코로나 19 와 같은 위기/재난상황이 발생했을 때 국제문화교류 사업 추진을 위해 필요한 정책에 대해 설문한 결과, 세부 정책별로 차이를 보였다. 필요하다는 응답 비중을 기준으로, '국제문화 교류 사업 기관 네트워킹 및 협업 강화' $91.0 \%$, '기관별 네트워크 구축 및 연계사업 개발' $88.0 \%$, '사업계획 플랜B 설계 지원' $88.0 \%$ 등의 순으로 나타났다. 다섯 번째, 코로나19 
팬데믹에서 벗어난 이후, 필요한 정책에 대해 설문하였다. 그 결과, 가장 높은 응답이 나온 항목은 '국제문화교류 국내체계 정비 93.0\%', '온라인/비대면 콘텐츠 제작·유통 활 성화 지원' $92.0 \%$, '국제문화교류 정책의 구체화, 체계화' $91.0 \%$ 등의 순으로 나타났다. 그 다음으로 비대면 온라인 상시 문화교류 사업 상시 기획 및 사업추진 $85 \%$, 한국국제문 화교류 온라인 플랫폼 구축 및 활용 활성화 $83 \%$, 공동창작.기획 및 민간단체(국민) 참여 형 국제문화교류 등 주체/형식/내용의 다변화 $81 \%$, 실험적인 창작활동의 국제교류·협업 활성화 지원 81\% 순으로 중요도 인식을 보여주었다. 여섯 번째, 코로나19 팬데믹에서 벗어난 이후, 민간분야의 국제문화교류 활동 활성화를 위해 필요한 정부의 지원 형태에 대해 설문한 결과, 필요하다는 응답 비중을 기준으로 '온라인 디지털 국제문화교류 플랫 폼을 통한 활동 지원' $88.0 \%$, '국제문화교류 정보공유 및 활용 지원(네트워크 구축)' $88.0 \%$, 콘텐츠 디지털전환 등 인력 교육 및 장비사용 지원 $86 \%$, 사업비용 지원 $82 \%$, 한국 국제문화교류 온라인 플랫폼 구축 및 활성화 지원 $80 \%$ 등으로 나타났다.

본 보고서는 국제문화교류 활성화를 정책과제의 4 가지 범주로 $\mathbf{\Delta}$ 대전환기 가치기반 국제문화교류, $\mathbf{\Delta}$ 회복탄력성 제고를 위한 거버넌스 구축, $\mathbf{\Delta}$ 국제문화교류 관리체계 구 축, $\boldsymbol{\Lambda}$ 온라인-오프라인 융합 프로그램 등을 제시하였다. 먼저 "대전환기 가치기반 국제 문화교류"는 자국중심주의가 강화되는 시점에서 한국의 문화적 가치의 일방적 전달이 가져올 수 있는 역효과를 고려하여 한국의 문화적 자산과 보편적 가치를 융합할 필요성 을 제시한다. 이를 위해 (1) 국제적 규범과 조응하는 국제문화교류를 통한 공유가치를 창 출하고, (2) 보편적 가치 추구를 위한 국내 기반을 조성하며, (3) 문화ODA를 확대하고 문화주류화 전략을 추진하는 방안을 제안하였다.

둘째, “회복탄력성 제고를 위한 거버넌스 구축”에서는 최근 활발하게 논의되고 있는 문화예술분야 회복탄력성에 초점을 두어 이를 우리나라 국제문화교류 활성화 방안에 접 목시키는 방안을 제시하였다. 특히 코로나19 이후 변동성, 불확실성, 복잡성이 갈수록 증대될 것으로 예상되는 미래 상황에서 우리나라의 국제문화교류가 기민하고 민첩하게 대응하면서 새로운 가치를 창출하기 위한 토대 마련의 필요성을 강조하였다. 이러한 점 에서 최근 미래 정부가 갖춰야할 특징으로 주목받는 (4) 에자일(agile) 거버넌스를 국제 문화교류에 접목시킬 필요함을 논하였다. 또한, 정부, 공공기관 주도의 국제문화교류의 한계를 극복하기 위해 (5) 공공-민간부문과의 파트너십 강화를 위해, 특히 지방자치단체 와의 협업, 시민참여, 기업의 CRS, ESG 활동과의 연계를 강조하였다. 마지막으로는 근 
거기반 국제문화교류 정책을 위하여 현재 활용도가 낮은 '문화로'를 개선하거나 새로운

(6) 한국 국제문화교류 플랫폼을 구축할 것을 제안하였다.

셋째, 관리(management)적 관점에서 국제문화교류를 활성화하고 선진화하기 위한 정책과제를 도출하였다. 특히 국제문화교류의 규모가 확대될수록 납세자 관점에서 국제 문화교류가 유의미한 결과를 창출하였는지에 대한 관심이 증대될 것이고, 이는 결국 국 제문화교류 사업의 책무성을 제고하기 위한 구체적 노력을 전개하였는가라는 질문으로 연계된다. 이를 위해서는 무엇보다 국제문화교류의 성과 측정을 위한 지표를 개발하고, 성과를 측정하며, 환류하는 노력, 즉 (7) 국제문화교류 성과관리체계 구축이 필요하다. 물론 국제문화교류의 특성 상 그 성과를 측정하는 것은 쉽지 않지만, 이러한 어려움이 성과관리의 불필요함의 근거가 될 수는 없다. 또한, (포스트)코로나19 시대 다양한 리스 크가 예상되면서 이에 대한 (8) 위험관리의 필요성이 높아지고 있다. 마지막으로는 (문 화)ODA, (문화)공공외교, 국제기구 분담금, 민간 국제문화교류 등 (9) 다양한 국제문화 교류를 체계적·통합적으로 관리하기 위한 방안(민관 협의체 등)을 제시하였다.

넷째, 디지털 전환에 능동적으로 대응하고 새로운 가치를 창출하기 위한 "온라인 오프 라인 융합 프로그램"과 관련한 정책과제이다. 이를 위해서는 (10) 온라인 국제문화교류 인 프라 지원이 가장 시급하며, 그 필요성은 전문가 설문조사를 통해서도 확인되었다. 또한, (11) 한국문화체험 Kit 등 온라인 방식과 체험을 연계하는 다양한 실험과 (12) 메타버스 구 축을 통하여 국제문화교류를 디지털 가상화, 일상화하는 노력이 필요함을 강조하였다. 특히 메타버스의 경우, 우리나라의 다양한 문화, 관광지에 대한 소개와 상호작용뿐만 아 니라 한국어·문화 교육의 효과성을 제고할 수 있다는 점에서 시공간적 제약을 넘어서는 국제문화교류의 새로운 가능성을 제시해준다는 점에서 주목할 필요가 있다. 


\section{제2절 정책함의}

코로나19 팬데믹 상황은 국내외적으로 인적교류와 물적교류를 막는다는 점에서 국제 문화교류 정책과 관련 논의에 있어 매우 큰 장애물이다. 현재까지도 국내에서는 확진자 발생률이 떨어지지 않아 여전히 강도 높은 사회적 거리두기 정책을 수행하고 있어, 인적 교류에 어려움 상황이 지속되고 있다. 국제적으로도 필수적인 교류 상황이나 상품 교역 상황이 아닌 일반적인 관광이나 비즈니스 목적의 교류 등 민간 영역의 활동은 극히 제한 적으로 이루어지고 있다.

과거의 기술발달 수준이 낮았던 시대였다면, 매우 큰 위기가 국내외로 닥쳐왔을 것이 다. 하지만, 여러 가지 형태의 디지털 기술의 발달과 적용은 교류와 활동이 제약된 사회 생활을 유지할 수 있도록 해주고 있다. 이렇게 변화된 사회생활의 새로운 현상과 행태는 코로나가 완전히 극복된 이후에도 과거로 똑같이 돌아갈 수 없게 될 것이다. 더구나, 현 재의 코로나 관련 상황을 본다면, 치료제가 개발되지 않는다면, 코로나 상황이 완전히 종식되기는 힘든 상황이다.

따라서, 향후 정부의 정책방향을 설정할 때는 코로나 상황이 지속되는 국면과 코로나 완전히 사라진 국면을 모두 고려하여 내용을 구성하여야 할 것이다. 이렇게 예측되는 주변 환경 상황에서 국제문화교류는 지금까지 해오던 방식이 유지될 수 있을지, 국제문 화교류의 어려움을 극복하고 이번 기회를 기반으로 체계를 재정립하고, 한단계 더 높은 질적 발전을 추구할 것인지에 대한 고민을 해야 할 시점이다. 정부가 제시한 정책목표인 국제문화교류의 '새로운 기준' 정립에는 이러한 고민이 담겨야한다. 단순한 기술적, 단기 적 대응이 아닌 국제문화교류 정책 전반에 대한 재검토와 정립을 추구하는 속에서 장단 기적 새로운 대응에 대한 원칙을 수립하여야 한다.

한국의 공공영역에서 주도하는 국제문화교류 사업들은 각 사업 기관들의 고유 사업 목적에 맞게 독자적으로 이루어져온 측면이 강하고, 국제문화교류 사업을 진행하는 기관 간의 연계와 정보공유 등도 잘 이루어지지 않고 있다. 또한, 한국의 공공 분야 국제문화 
교류는 민간영역의 대중문화에 대한 전세계적 인기에 힘입어 상당히 편리하게 이루어지 는 측면도 분명하다.

향후 한국이 문화선진국으로서 발돋움하고 국제문화교류를 선도적으로 진행하는 국 가로서 자리매김하려면, 현 상황에 머물지 않고 국제문화교류 정책의 전반을 검토하고, 향후 질적 향상을 위한 방안을 국제문화교류 주체들이 함께 고민해야할 시점이다. 각자 의 고유 사업 목적에 따른 국제문화교류 사업이 진행되더라도, 함께 공유해야할 것들이 무엇인지 검토해볼 필요가 있다. 해외 주요국가들의 시례를 살펴보아도, 각기 상황에 따 른 여러 가지 형태의 국제문화교류 사업들을 진행하고 있다. 그렇다면, 한국의 상황에서 필요한 국제문화교류 활성화 방안은 무엇인지 진지하게 고민할 필요가 있다.

본 연구에서는 공통의 가치 비전을 설정하는 것을 우선 제시하였다. 그리고 국제의 정책체계 정비, 성과관리 체계 구축, 위기관리 방안 등의 모색 등을 제시하였다. 이는 향후 포스트 코로나 시대를 대비하는 국제문화교류 활성화를 위한 가장 기초적인 작업 의 성격을 가진다. 본 연구에서 제시한 과제들은 가장 기초적인 작업이면서 가장 어려운 과제일 수 있다. 이 토대를 구축하는 사업을 진행하기 위해서는 어느 한기관의 주체적 노력만으로는 이룰 수 없고, 국제문화교류 거버넌스 체계 속에서 각 분야의 국제문화교 류 주체들의 상호 협력과 공통의 노력을 기반으로 하여야만 이루어질 수 있는 것이다. 국내외적으로 거의 모든 교류에 어려움을 만들어낸 코로나 시대에 국제문화교류의 체계 를 어떻게 정립해나갈 것인지에 대한 모두의 공감대와 노력이 필요한 시점이다. 



\section{참고문헌}

- 강현주. 2020. 「이슈보고서: 한국 경제의 장기추세와 코로나 19 자본시장연구원,

- 권기헌. 2018. "새로운 행정학의 개념탐색을 위한 전제: 좋은 거버넌스와 제4세대 정 부모형의 구현 조건." 「국정관리연구」, 13(1), pp.1-27.

- 고삼석. 2019. $55 \mathrm{G}$ 초연결사회, 완전히 새로운 미래가 온다」메디치

- 관계부처 합동. 2021. "한국판 뉴딜 2.0 : 미래를 만드는 나라 대한민국"

- 김광석. 2018. 「한 권으로 먼저 보는 2019 경제전망」이지퍼블리싱

- 김경일. 2020. “제12장 포스트코로나 시대의 심리적 방향성”「미래의 귀환」(김소영 외) 한울아카데미, pp. 159-161

- 김대륜. 2020. “제5장 코로나19 사태와 글로벌 가치사슬”「미래의 귀환」(김소영 외) 한울아카데미

- 김동현·마정산. 2020.「비대면 비즈니스트렌드」정보문화사

- 김소영 외. 2020.「미래의 귀환」 한울아카데미,

- 김우진. 2020. "26장. 코로나19 이후 사회 양극화와 주택시장"「포스트코로나 대한민 국: 집단지성 27 인의 성찰과 전망」(이영환 외) 한울엠플러스

- 김준형. 2020.「코로나 $19 \times$ 미국대선, 그 이후의 세계」평단

- 김학민. 2020. “제4장 4차 산업혁명, 지역경제 업그레이드, 글로벌 가치사슬" 「미래의 귀환」(김소영 외) 한울아카데미

- 김혜인최보연·송철재·이세정. 2017. “국제문화교류 지표개발 기초연구” 문화체육관광부

- 김혜인·김연진. 2020.「2020 문화예술트렌드 분석 및 전망 보고서」한국문화관광연구원

- 노무라종합연구소. 2020.「코로나 대전환」(주알에이치코리아

- 다니엘 슈텔터. 2020.「코로노믹스」더숲

- 버나드 마. 2020.「다가온 미래」다산북스

- 산업연구부문 미래산업그룹. 2018. 「2018 주요 디지털 기술·산업 이슈」 LG 경제연구원

- 이대우. 2020. "제 2 장 미국의 세계전략과 중국"「미중 패권시대 한국의 대외전략」(이 상현 외) 세종연구소 
- 이상열·정종은. 2017.「미래문화정책의 방향과 과제」한국문화관광연구원,

- 이상엽. 2020. “코로나 19가 야기한 4차 산업혁명의 가속"「미래의 귀환: 코로나 19 와 4차 산업혁명 대전환」(김소영 외) 한울아카데미

- 이상현 외. 2020.「미.중 패권시대 한국의 대외전략」세종연구소

- 이성우·이영유. 2021. “한국 국제개발협력과 문화 ODA."「문화정책논총」, 35(1), pp.191-225.

- 이영환 외 2020.「포스트코로나 대한민구: 집단지성 27인의 성찰과 전망」 한울엠플러스

- 임현. 2020. “제 17 장 4차 산업혁명 기술 발전 및 시장 수요 전망”「미래의 귀환」(김소 영 외) 한울아카데미

- 양혜원·김면·차민경·김현경·노수경. 2020. 「코로나 19가 문화예술분야에 미친 영향 및 정책대응방안 연구」 한국문화관광연구원,

- 오정은. 2016. 「난민사태 이후 유럽공동이민망명정책의 변화」 IOM이민정책연구원

- 유현석. 2021. 「국제정세의 이해」한울엠플러스

- 외교부. 2017.「제1차 대한민국 공공외교 기본계획(2017 2021)」

- 외교부. 2021.「2021년도 공공외교 종합시행계획 I권」

- 문형남. 2020. "21장. 언택트혁명: 사회적 거리두기 기술(SDT) 유망" 「포스트코로나 대한민국: 집단지성 27 인의 성찰과 전망」(이영환 외) 한울엠플러스

- 장은진. 2020. "10장. 코로나 19와 심리방역"「포스트코로나 대한민국: 집단지성 27 인의 성찰과 전망」(이영환 외) 한울엠플러스.

- 정용찬. 2017. "1인가구의 매체보유와 이용특성." KISDISTAT Report Vol.17-10. 정보통신정책연구원

- 정재흥. 2020. “제3장 중국의 세계전략과 미국”「미중 패권시대 한국의 대외전략」(이 상현 외) 세종연구소,

- 한국경제신문 CES 2021 특별취재팀. 2021. 「CES 2021」한국경제신문

- 한국은행. 2020. "코로나19 글로벌 확산이 세계 경제에 미치는 영향." (국제경제리뷰, 제2020-9호).

- 한국은행. 2020. “최근 세계교역의 주요특징 및 향후전망." 「국제경제리뷰」 제2020-25호,

- 한상춘. 2019. 「또 다른 10년이 온다: 2020-2030 경제의 미래」한국경제신문

- 한준경. 2006. "한국경제의 양극화 원인과 영향 및 정책과제"「사회과학논총」 Vol.8, pp.483 504.

- 허연주 \& 이민규. 2017. "사회적 재난으로 인한 간접외상 척도의 개발과 타당화 연 
구.” 「한국심리학회지: 문화 및 사회문제」, Vol.23, No.3, pp. 381-407

- 4차산업혁명 융합법학회. 2020.「4차 산업혁명의 이해」박영사

- Allison, Graham. 2020. "The New Spheres of Influence, Sharing the Globe with Other Great Powers.” Foreign Affairs, Vol. 99, No. 2,

- European Parliament Cult Committe. 2021. "Cultural and creative sectors in post-COVID19 Europe : Crisis effects and policy recommendations." European Parliament

- Guiber, Greg and Lain Hyde. 2021. "Covid-19 Weekly Outlook.” COVID-19 RSFLG Data and Assessment Working Group. p.6.

- Knudsen, H. K., Roman, P. M., Ducharme, L. J., \& Johnson, J. A. 2005. "Organizational predictors of pharmacological innovation adoption: The case of disulfiram." Journal of Drug Issues, Vol. 35, No. 3, pp. 559-573

- Norris, F. H., Friedman, M. J., \& Watson, P. J. 2002. “60,000 disaster victims speak: Part II. Summary and implications of the disaster mental health research." Psychiatry: Interpersonal and biological processes, Vol.65m No.3, pp.240-260.

- OECD. 2020. "Social partnership in the times of the COVID-19 Pandemic", OECD Policy Responses to Coronavirus (COVID-19), OECD Publishing, Paris.

- Rivoli, P. 2014. The travels of a t-shirt in the global economy: An economist examines the markets, power, and politics of world trade. New preface and epilogue with updates on economic issues and main characters. John Wiley \&Sons.

- UNESCO. 2020. 5. 18. "Virtual Museum on underwater cultural heritage respond to the Covid-19 crisis"

- United Cities and Local Governments. 2018. "Culture in the Sustainable Development Goals: A Guide for Local Action”

- World Economic Forum, WEF). 2012. 『The Future of Government: Lessons Learned from around the World』

- World Economic Forum. 2020.7. “Top factors travelers will consider before planning a trip - what hard-hit countries can consider"

- 국학신문사. 2021.5.18. “공예품도 VR로 쇼핑한다, ‘공예정원' 가상현실(VR) 스토어 오픈” 
- 남도일보. 2020.12.27. “광주 5·18민주화운동 게임으로 배워요” 아시아문화원, “오월 스토리 퍼즐' 선봬"

- 남도일보. 2020.12.28. "아시아문화원, 지역문화예술지원사업 성료"

- 뉴시스. 2020.10.11. "국립중앙도서관, 코로나 웹사이트 개설...전국 도서관 서비스."

- 뉴시스. 2020.11.3. “국가대표' 국립중앙도서관 75주년 발자취, 온라인 전시.”

- 뉴시스. 2020.12.2. “국립중앙박물관” '마인크래프트' 가상전시 체험하세요."

- 뉴시스. 2020.12.15. "OECD 총장 "다자주의, 코로나 재건 유일한 길...바이든 기대"”

- 뉴시스. 2021.5.21. "국립중앙박물관, 최첨단 전시 눈길...3D 모션 캡처 영상체험."

- 대한민국 정책브리핑. 2021.01.28. "문 대통령 "국제사회 코로나 대응, 연대·협력·다 자주의·포용 정신 되살려야”

- 문화뉴스. 2020.10.6. "국립민속박물관, 초등학생 대상교과 연계 온라인 콘텐츠 제공"

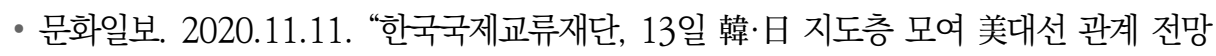
'한일포럼'”

- 문화일보. 2020.12.28. "한국콘텐츠진흥원, 30-31일 온택트 공연 콘텐츠 '콘투어 백 스테이지' 선보여"

- 미디어리퍼블릭. 2020.8.3. “직장인 문화예술교육 지원사업 '예술심표' 전국 5개 지역 에서 진행"

- 불교뉴스. 2020.9.22. "스마트 뮤지엄 본격 가동...박물관 첫 사례"

- 서울문화투데이. 2020.12.2. “지역공예가들을 위한 온라인 컨설팅 운영”

- 서울신문. 2020.9.2. "멀어진 거리만큼... 국악도 멀어졌네"

- 아시아경제. 2020.07.09. “위기에 강했던 '유럽 극우 포퓰리즘'의 코로나19 겪으며 몰락".

- 이데일리. 2020.11.26. “조선총독부박물관 유리건판”통해 한국 미술사 조명한다”

- 연합뉴스. 2016.03.06. "구조적 장기침체 빠진 한국경제... 10대 지표 올 마이너스."

- 웰페어뉴스. 2020.7.9. "국립민속박물관, 장애인과 노인 맞춤형 온라인 콘텐츠 제공"

- 중앙SUNDAY. 2019.5.4. “반난민' 극우파들 뭉쳤다...'우향우’로 기우는 유럽의회.”

- 한국강사신문. 2020.11.5. "문화체육관광부·한국문화예술교육진흥원 "비대면 문화예 술교육' 시범사업 추진"

- 한국경제신문. 2018.6.17. "난민문제가 $\mathrm{EU}$ 분열 불씨...포용 내세운 독일서도 내부갈등”

- 한겨레. 2011.4.27. “프랑스·이탈리아 솅겐 협정 개정 추진"

- 한겨레. 2020.1.1. “신 3저 시대를 사는 법” 
- New York Times. 2020. 5. 4. "I spent a weekend bingeing Airbnb's virtual experiences. Was it worth it?" 



\section{ABSTRACT}

\section{A Study of Invigorating International Cultural Exchange After COVID-19}

Lee Sungwoo

This Study's primary goal is to assess the environmental situation, expert's perception in this field, international cultural exchange programs in Korea and other countries, to the invigoration of Korean international cultural exchange policies after Covid-19. This Study suggests some ways to the invigoration of Korean international cultural exchange policies. First, Korean international cultural exchange policy needs to establish common visions, which every Korean agency shared, based on traditional Korean values and SDGs\&5P. Second, the government has to build Earned Value Management System and risk management system of international cultural exchange programs. Third, there needs agile governance between public agencies focusing on invigorating international cultural exchange programs. Last, governments have to support building infrastructure for digital transformation and use new digital technologies such as metaverse in international cultural exchange programs.

\section{Keywords}

International Cultural Exchange, Agile Governance, SDGs, Cultural Diplomacy, Partnership 

코로나19 이후 국제문화교류 활성화방안 연구

\section{부록}

설문지 



\section{코로나19 이후 국제문화교류 활성화 방안에 대한 설문조사}

\section{I. 국제문화교류 현황}

국제문화교류 정의 : 「국제문화교류진흥법」제2조

문화, 예술, 관광, 체육 등의 관련 분야에서 국가 간 상호 문화(예술, 관광, 체육 등을 포함하는 넓은 의미의 문화를 말한다)에 대한 이해를 증진하기 위하여 수행하는 국제적 협력 및 활동

문1. 귀하께서는 코로나19 팬데믹이 진정된 이후 국제문화교류가 코로나19 팬데믹 이전 상황으로 양적/질적으로 회복될 수 있을 것이라고 생각하십니까?
1) 전혀 그렇지 않다
2) 그렇지 않다
3) 그렇다
4) 매우 그렇다

문2. 한국의 외교정책 수행에 있어서 국제문화교류가 얼마나 중요한 부분을 담당한다고 생각하십 니까?

\begin{tabular}{l|c|c|c|c}
\hline \multirow{2}{*}{ 항 목 } & 전혀 중요하지 않다 & 별로 중요하지 않다 & 중요하다 & 매우 중요하다 \\
\cline { 2 - 5 } & 1) & 2) & 3) & 4) \\
\hline 1) 코로나19 이전 & & & & \\
\hline 2) 코로나19 기간 내 & & & & \\
\hline 3) 코로나19 이후 & & &
\end{tabular}

문3. 코로나19로 인하여 비대면 방식으로 국제문화교류 사업이 수행되는 경우가 많습니다. 대면 방식의 사업 수행이 사업 효과성 측면에서 어느 정도 효과가 있다고 생각하십니까?
1) 전혀 효과 없다.
2) 거의 효과 없다.
3) 비슷하다.
4) 효과가 있다.
5) 매우 효과가 크다.

문3-1. (문3의 1), 2), 3) 응답자만) 국제문화교류 사업의 비대면 방식의 수행이 대면방식의 수행보다 왜 덜 효과적인지 기술해주십시오. 
문3-2. (문3의 4), 5) 응답자만) 국제문화교류 사업의 비대면 방식의 수행이 대면방식의 수행보 다 왜 더 효과적인지, 기술해주십시오.

문4. 코로나19로 인하여 국제문화교류 사업의 변동과 중단이 많이 발생하였습니다. 어떤 국가들 을 대상으로 한 국제문화교류 사업이 가장 많이 변동이 있었다고 생각하십니까?
1) 후진국
2) 개발도상국
3) 중진국
4) 선진국
5) 큰 차이 없다

문5. 귀하께서는 코로나19 팬데믹 기간 내 교류사업을 온라인으로 참여해 보셨습니까?

1) 예 문5-1로 이동

2) 아니오 문5-3으로 이동

문5-1. (문5의 1) 응답자만) 귀하께서 참여하신 온라인/비대면 콘텐츠의 활용방식은 무엇이었 습니까? 해당되는 것은 모두 응답해주세요. (복수응답)
1) 라이브 스트리밍
2) 녹화 영상의 송출
3) 온라인 뷰잉룸(online viewing room)
4) 가상현실(VR)/증강현실(AR) 등 실감콘텐츠
5) 기타

문5-2. (문5의 1) 응답자만) 귀하께서 참여하신 해당 온라인/비대면 프로그램이 유통·송출된 플랫폼은 어디입니까? 해당되는 것은 모두 응답해주세요 (복수응답)

응답 후 문6으로 이동
1) TV방송
2) 유명 SNS
3) 유명 인터넷 플랫폼
4) 기관 홈페이지
5) 온라인 예술 콘텐츠 플랫폼(artnet, artsy, eazel, cava.life 등)
6) 온라인 화상회의 앱(줌(Zoom), 구글 미트(Google Meet) 등) 
7) 기타

문5-3. (문5의 2) 응답자만) 온라인/비대면 프로젝트에 참여하지 않은 이유는 무엇입니까? 해 당되는 것은 모두 응답해 주십시오. (복수응답)

1) 온라인/비대면 콘텐츠 활용이 적절하지 않아서

2) 온라인/비대면 콘텐츠 제작/중계/송출/유통을 위한 시설이나 장비가 없어서

3) 온라인/비대면 콘텐츠 제작/중계/송출/유통을 위한 기술을 몰라서

4) 온라인/비대면 콘텐츠 제작/중계/송출/유통을 위한 방법을 몰라서

5) 온라인/비대면 콘텐츠 제작/중계/송출/유통을 위한 비용이 없어서

6) 기타

\section{II. 국제문화교류 정책/사업만족도}

문6. 코로나19 이전과 비교하여, 코로나19 이후 발생한 여러 변화가 국제문화교류 사업 진행에 얼마나 영항을 미쳤다고 생각하십니까?

\begin{tabular}{l|c|c|c|c|c|c}
\hline \multicolumn{1}{c|}{ 항 목 } & $\begin{array}{c}\text { 전혀 } \\
\text { 향영 없 } \\
\text { 다 }\end{array}$ & $\begin{array}{c}\text { 영향이 } \\
\text { 크게 없 } \\
\text { 다 }\end{array}$ & $\begin{array}{c}\text { 보통 } \\
\text { 이다 }\end{array}$ & $\begin{array}{c}\text { 영향이 } \\
\text { 크다 }\end{array}$ & $\begin{array}{c}\text { 매우 영 } \\
\text { 향을 미 } \\
\text { 쳤다 }\end{array}$ \\
\cline { 2 - 6 } & 1) & 2) & 3) & $4)$ & 5) \\
\hline $\begin{array}{l}\text { 1) 재택근무, 사회적 거리두기, 비대면 문화의 확산 등 } \\
\text { 사회적 변화 }\end{array}$ & & & & & \\
\hline 2) 디지털 기술 활용 중심으로 한 기술적 변화 & & & & & \\
\hline 3) 교류 중단, 연기 등 국제정치 상황의 변화 & & & & & \\
\hline $\begin{array}{l}\text { 4) 비대면 경제 활성화, 경기침체, 경제활동 양상의 변 } \\
\text { 화 등 경제적 상황 변화 }\end{array}$ & & & & & \\
\hline 5) 대면 공연 전시 등의 어려움, 온라인 문화콘텐츠 활 & & & & & \\
용 등 문화생활 변화 & & & & & \\
\hline
\end{tabular}


문7. 코로나19 전후 국제문화교류 사업에 대한 정부의 정책과 지원에 대해 전반적으로 만족하십 니까?

\begin{tabular}{c|c|c|c|c|c}
\hline \multirow{2}{*}{ 항 목 } & $\begin{array}{c}\text { 매우 불만 } \\
\text { 족 }\end{array}$ & 불만족 & $\begin{array}{c}\text { 보통 } \\
\text { 이다 }\end{array}$ & 만족 & 매우 만족 \\
\cline { 2 - 6 } & 1) & 2) & 3) & 4) & 5) \\
\hline 1) 코로나19 이전 & & & & & \\
\hline 2) 코로나19 이후 & & & & & \\
\hline
\end{tabular}

문8. 귀하께서는 코로나19로 인하여 국제문화교류사업을 원활하게 진행하기 힘든 상황에서 정부 로부터 받았거나, 향후 지원이 필요한 사안에 대해 어떻게 생각하십니까?

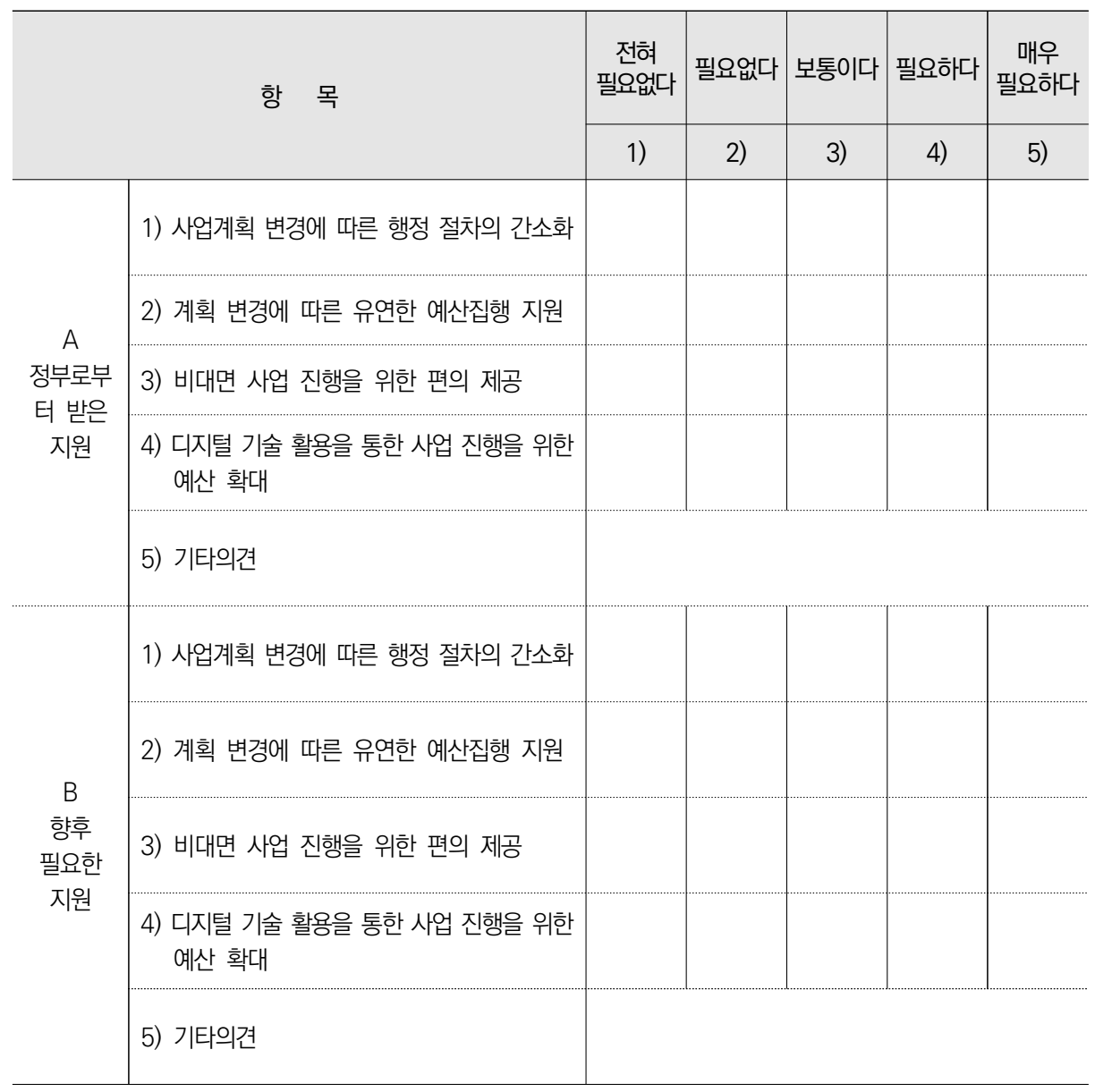


문9. 코로나19 이전과 비교하여, 코로나19와 같은 위기/재난상황에서 국제문화교류 사업 추진을 위해 다음의 정책이 얼마나 필요하다고 생각하십니까?

\begin{tabular}{|c|c|c|c|c|c|}
\hline \multirow[t]{2}{*}{ 항 목 } & $\begin{array}{c}\text { 전혀 } \\
\text { 필요 } \\
\text { 하지않다 }\end{array}$ & $\begin{array}{c}\text { 필요 } \\
\text { 하지않다 }\end{array}$ & 보통이다 & 필요하다 & $\begin{array}{c}\text { 매우 } \\
\text { 필요하다 }\end{array}$ \\
\hline & 1) & 2) & 3) & 4) & 5) \\
\hline \multicolumn{6}{|l|}{ 1) 예산확대 및 예산 계획 수립과 집행의 자율성 증대 } \\
\hline \multicolumn{6}{|l|}{ 2) 디지털 기술 활용 활성화 방안 개발 } \\
\hline \multicolumn{6}{|l|}{ 3) 전문인력 양성 확대 } \\
\hline \multicolumn{6}{|l|}{ 4) 해외 현지 활동 문화원(사무소) 확대 } \\
\hline \multicolumn{6}{|l|}{ 5) 국제문화교류 사업 기관 네트워킹 및 협업 강화 } \\
\hline \multicolumn{6}{|l|}{ 6) 국제문화교류 전담기관 사업 및 예산 확대 } \\
\hline \multicolumn{6}{|l|}{ 7) 정부 부처간 협력 강화 } \\
\hline \multicolumn{6}{|l|}{ 8) 기관별 네트워크 구축 및 연계사업 개발 } \\
\hline \multicolumn{6}{|l|}{ 9) 통합상담센터 운영 및 정보제공 } \\
\hline \multicolumn{6}{|l|}{$\begin{array}{l}\text { 10) 위기(재난) 발생 시 사업계획에 대한 가이드라인 제작 } \\
\text { 및 배포 }\end{array}$} \\
\hline \multicolumn{6}{|l|}{ 11) 사업계획 플랜B 설계 지원 } \\
\hline \multicolumn{6}{|l|}{ 13) 온라인/비대면 콘텐츠 제작·유통 활성화 지원 } \\
\hline \multicolumn{6}{|l|}{ 14) 국제문화교류 사업을 위한 사전 조사.연구 지원 } \\
\hline \multicolumn{6}{|l|}{ 15) 역량강화를 위한 교육·훈련 지원 } \\
\hline 16) 기타 의견 & & & & & \\
\hline
\end{tabular}


문10. 귀하께서는 코로나19 이후 국제문화교류 활성화를 위한 다음의 정책들이 어느 정도 필요하 다고 생각하십니까?

\begin{tabular}{|c|c|c|c|c|c|}
\hline \multirow[t]{2}{*}{ 항 목 } & $\begin{array}{l}\text { 전혀 필요 } \\
\text { 하지않다 }\end{array}$ & $\begin{array}{c}\text { 필요 } \\
\text { 하지않다 }\end{array}$ & 보통이다 & 필요하다 & $\begin{array}{l}\text { 매우 } \\
\text { 필요하다 }\end{array}$ \\
\hline & 1) & 2) & 3) & 4) & 5) \\
\hline \multicolumn{6}{|l|}{$\begin{array}{l}\text { 1) 가치 지향적 국제문화교류 정책을 위한 공통 가치 } \\
\text { 비전의 정립 }\end{array}$} \\
\hline \multicolumn{6}{|l|}{ 2) 국제문화교류 정책의 구체화, 체계화 } \\
\hline \multicolumn{6}{|l|}{ 3) 국제문화교류 국내체계 정비 } \\
\hline \multicolumn{6}{|l|}{ 4) 국제문화교류 사업 성과관리체계 구축 } \\
\hline \multicolumn{6}{|l|}{$\begin{array}{l}\text { 5) 국제문화교류 위한 문화 콘텐츠 생산, 소비, 유통 등 } \\
\text { 세부분야별 사업 지원 }\end{array}$} \\
\hline \multicolumn{6}{|l|}{$\begin{array}{l}\text { 6) 한국 국제문화교류 온라인 플랫폼 구축 및 활용 활 } \\
\text { 성화 }\end{array}$} \\
\hline \multicolumn{6}{|l|}{$\begin{array}{l}\text { 7) 공동창작·기획 및 민간단체(국민) 참여형 국제문화 } \\
\text { 교류 등 주체·형식.내용의 다변화 }\end{array}$} \\
\hline \multicolumn{6}{|l|}{ 8) 실험적인 창작활동의 국제교류·협업 활성화 지원 } \\
\hline \multicolumn{6}{|l|}{$\begin{array}{l}\text { 9) 해외 실감콘텐츠(K-Pop, 영화, 게임, 문화유산) 체 } \\
\text { 험관 구축 }\end{array}$} \\
\hline \multicolumn{6}{|l|}{$\begin{array}{l}\text { 10) 국내 공연단체 대표 작품의 해외 진출용 프로모션 } \\
\text { 영상 제작 지원 }\end{array}$} \\
\hline \multicolumn{6}{|l|}{$\begin{array}{l}\text { 11) 소장자료 디지털화, 온라인 아트페어 개최 지원 및 } \\
\text { 공유시장, 미술작품 구독 등 비대면 사업 지원 }\end{array}$} \\
\hline \multicolumn{6}{|l|}{ 12) 온라인/비대면 콘텐츠 제작·유통 활성화 지원 } \\
\hline \multicolumn{6}{|l|}{$\begin{array}{l}\text { 13) 비대면 한국어 학습 지원 확대(온라인 세종학당 플 } \\
\text { 랫폼 활용, 학습 콘텐츠 제공, 온라인 교육과정 개설 및 } \\
\text { 운영 지원) }\end{array}$} \\
\hline \multicolumn{6}{|l|}{ 14) 한국 여행, 관광, 문화 콘텐츠 온라인 홍보 } \\
\hline \multicolumn{6}{|l|}{$\begin{array}{l}\text { 15) 비대면 온라인 상시 문화교류 사업 상시 기획 및 } \\
\text { 사업 추진 }\end{array}$} \\
\hline 16) 기타 의견 & & & & & \\
\hline
\end{tabular}


문11. 정부는 코로나19 이후 민간분야의 국제문화교류 활동 활성화를 위해 어떤 형태로 지원을 해야 한다고 생각하십니까?

\begin{tabular}{|c|c|c|c|c|c|}
\hline \multirow[t]{2}{*}{ 항 목 } & $\begin{array}{l}\text { 전혀 필요 } \\
\text { 하지 않다 }\end{array}$ & $\begin{array}{l}\text { 필요 } \\
\text { 하지 } \\
\text { 않다 }\end{array}$ & $\begin{array}{l}\text { 보통 } \\
\text { 이다 }\end{array}$ & $\begin{array}{l}\text { 필요 } \\
\text { 하다 }\end{array}$ & $\begin{array}{l}\text { 매우 } \\
\text { 필요 } \\
\text { 하다 }\end{array}$ \\
\hline & 1) & 2) & 3) & 4) & 5) \\
\hline 1) 사업비용 지원 & & & & & \\
\hline 2) 영사서비스 및 해외사무소 업무지원 & & & & & \\
\hline 3) 사업공모 등을 통한 사업지원 & & & & & \\
\hline $\begin{array}{l}\text { 4) 콘텐츠 디지털 전환 등 인력교육 및 장비 사용 } \\
\text { 지원 }\end{array}$ & & & & & \\
\hline $\begin{array}{l}\text { 5) 온라인 디지털 국제문화교류 플랫폼을 통한 } \\
\text { 활동 지원 }\end{array}$ & & & & & \\
\hline $\begin{array}{l}\text { 6) 한국 국제문화교류 온라인 플랫폼 구축 및 활용 } \\
\text { 활성화 }\end{array}$ & & & & & \\
\hline $\begin{array}{l}\text { 7) 국제문화교류 정보공유 및 활용 지원 } \\
\text { (네트워크 구축) }\end{array}$ & & & & & \\
\hline 8) 기타 의견 & & & & & \\
\hline
\end{tabular}

문12. 코로나19로 인하여 디지털 기술을 활용한 비대면 방식의 교류가 많이 이루어지고 있습니다. 귀하께서는 코로나19 이후 국제문화교류 분아에서 디지털 콘텐츠 제작 사업이 어느 정도 활 용될 것으로 생각하십니까?

1) 크게 확대될 것이다

2) 지금 정도 수준의 확대가 지속될 것이다

3) 일시적인 현상으로, 코로나 19 가 종식되면 다시 축소될 것이다

4) 모르겠다

문13. 귀하는 국제문화교류관련 업무를 수행하시거나 사업을 계획하실 때 온라인/비대면 콘텐츠 를 활용하실 의향이 있으십니까?
1) 있다
2) 없다
3) 생각해본 적 없다 
문14. 코로나19 이후 온라인/비대면 콘텐츠의 부상에 대한 다음과 같은 전망과 평가에 대해 어떻 게 생각하십니까?

\begin{tabular}{l|c|c|c|c|c}
\hline & $\begin{array}{c}\text { 전혀 } \\
\text { 그ㅇㅓㅓㅇㅈㅣ } \\
\text { 않다 }\end{array}$ & $\begin{array}{c}\text { 그렇지 } \\
\text { 않다 }\end{array}$ & $\begin{array}{c}\text { 보통 } \\
\text { 이다 }\end{array}$ & 그렇다 & $\begin{array}{c}\text { 매우 } \\
\text { 그렇다 }\end{array}$ \\
\cline { 2 - 6 } & 1) & 2) & 3) & 4) & 5) \\
\hline $\begin{array}{l}\text { 1) 접근성 확대에 기여할 것이다. } \\
\text { (물리적, 시간적, 경제적, 심리적 접근성 제고) }\end{array}$ & & & & & \\
\hline $\begin{array}{l}\text { 2) 새로운 사업 확대에 기여할 것이다. (국제문화교류 } \\
\text { 향유자가 오프라인에서 온라인으로 신규 유입) }\end{array}$ & & & & & \\
\hline $\begin{array}{l}\text { 3) 폭넓은 의미의 문화(문화, 예술, 관광, 체육 등) 가운 } \\
\text { 데 특수 분야에서 주로 활용 될 것이다. }\end{array}$ & & & & & \\
\hline
\end{tabular}

문15. 온라인/비대면 콘텐츠 활성화를 위해 어떠한 정책적 지원이 필요하다고 생각하십니까? 해 당되는 것은 모두 응답해주세요. (복수응답)

1) 온라인/비대면 콘텐츠 제작비용 지원

2) 온라인/비대면 콘텐츠를 제작할 수 있는 공간 및 시설·장비 지원

3) 온라인/비대면 콘텐츠 제작인력 지원

4) 온라인/비대면 콘텐츠 제작 관련 교육 지원

5) 온라인/비대면 콘텐츠 유통 플랫폼 구축 및 유통 활성화 지원

6) 온라인/비대면 콘텐츠 홍보 지원

7) 기타

문16. 귀하께서는 문화체육관광부의 국제문화교류 종합정보시스템 ‘문화로'를 활용해본 경험이 있으십니까?

1) 예 문16-1로 이동

2) 아니오 
문16-1. '문화로'를 통한 정보가 실제로 도움이 되었습니까?

\begin{tabular}{c|c|c|c|c|c}
\hline \multirow{2}{*}{ 항 목 } & $\begin{array}{c}\text { 전혀 도움이 } \\
\text { 안 되었다 }\end{array}$ & $\begin{array}{c}\text { 도움이 } \\
\text { 안 된 편이다 }\end{array}$ & $\begin{array}{c}\text { 보통 } \\
\text { 이다 }\end{array}$ & 도움이 되었다 & $\begin{array}{c}\text { 매우 } \\
\text { 도움이 되었다 }\end{array}$ \\
\cline { 2 - 6 } & 1) & 2) & 3) & 4) & 5) \\
\hline 1) 코로나19 이전 & & & & & \\
\hline 2) 코로나19 이후 & & & & & \\
\hline
\end{tabular}

문16-2. 코로나19 이후 ‘문화로’를 어떻게 개선해야 한다고 생각하십니까?
1) 다양한 기관 및 사업에 대한 정보 보완
2) 수요자 관점 나라별, 분야별 메뉴 추가 구성
3) 지원분야 확대
4) 분야별 기관명 소개 및 검색 서비스 제공
5) 외국어 서비스 확대
6) 웹사이트 적극적인 홍보
7) 한국 국제문화교류 종합플랫폼으로 기능강화 

집필내역

연구책임

이성우 한국문화관광연구원 부연구위원: 제 1 장, 제 2 장, 제 3 장 제1절 제3절 일부, 제4장, 제5장 일부, 연구총괄

연구진

조현성 한국문화관광연구원 선임연구위원: 제3장 제1절

정헌주 연세대학교 행정학과 교수: 제5장

한미애 계명대학교 국제학연구소 연구교수 : 제4장

코로나19 이후 국제문화교류 활성화방안 연구

발행 인 김 대관

발 행 처 한국문화관광연구원

서울시 강서구 금낭화로 154

전화 02-2669-9800 팩스 02-2669-9880

http://www.kcti.re.kr

인 쇄 일 2021년 10월 15일

발행일 2021년 10월 15 일

인 쇄 인 (사)한국장애인이워크협회 일자리사업장

I S B N 978-89-6035-882-9 93300

DOI https://doi.org/10.16937/kcti.rep.2021.e20

이 연구보고서를 인용하실 때는 다음과 같은 사항을 기재해 주십시오.

이성우(2021), 코로나19 이후 국제문화교류 활성화방안 연구, 한국문화관광연구원 


\section{OPEN}

한국문화관광연구원

서울특별시 강서구 금낭화로 154

전화 02-2669-9800

팩스 02-2669-9880

www.kcti.re.kr 